Bősz Anett

\title{
A LIBERALIZMUS GAZDASÁGELMÉLETI HAGYOMÁNYAI, KÜLÖNÖS TEKINTETTEL AZ ETIKAI MEGALAPOZÁSRA
}


Világgazdasági tanszék

Témavezető:

Dr. Trautmann László CSc 


\title{
BUDAPESTI CORVINUS EGYETEM
}

\author{
Nemzetközi Kapcsolatok \\ Multidiszciplináris Doktori Iskola
}

\begin{abstract}
A liberalizmus gazdaságelméleti hagyományai, különös tekintettel az etikai megalapozásra
\end{abstract}

Doktori értekezés

Bősz Anett

Budapest, 2020 


\section{Tartalomjegyzék}

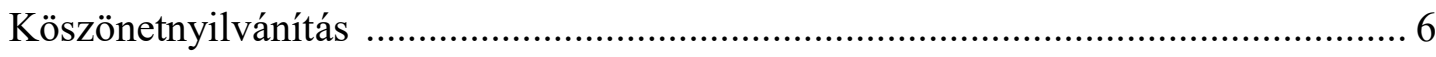

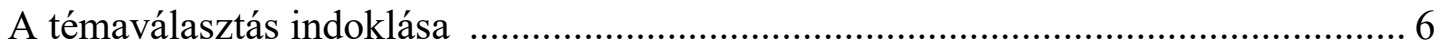

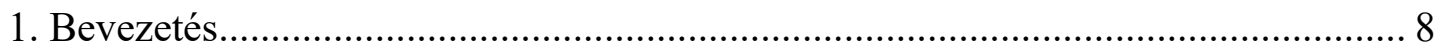

1.1. Az eszmerendszerek meghaladásának felvetése ......................................... 24

1.2. Mire használhatók a liberalizmus előző eszmetörténeti szakaszában elkövetett

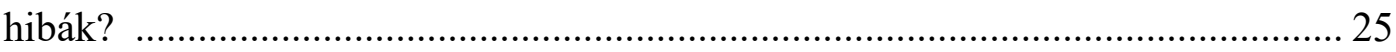

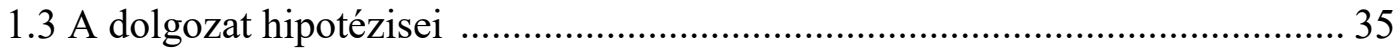

1.4. A dolgozat módszertana és a szakirodalmi háttér bemutatása ...................... 36

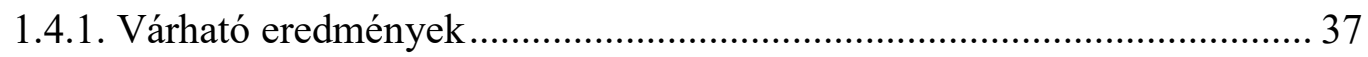

2. A klasszikus liberalizmus gazdaságstratégiai és társadalomszervezési ajánlata ... 38

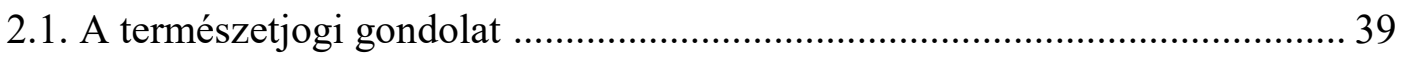

2.2. Állam és egyén viszonya, vallásszabadság és polgári jogok a XVII. századi

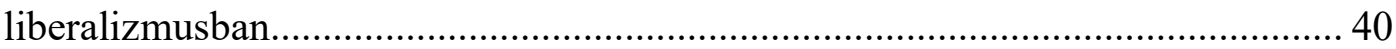

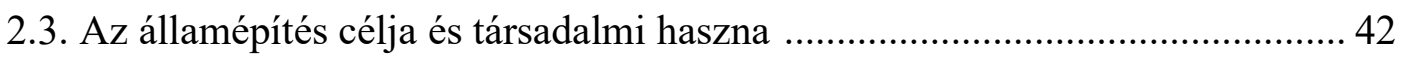

2.4. A kereskedőtársadalom mint morális érték és értékképző intézmény Smithnél

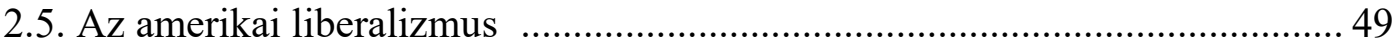

2.6. Szabad társadalom - szabad kereskedelem - a XIX. századi brit liberalizmus a klasszikus angol politikai gazdaságtanban .................................................... 51

2.7. Mill és a XIX. század második felének liberalizmusa ................................. 52

2.8. Republikánus vagy liberális elvek? ............................................................. 53

3. A XX. századi liberalizmus - neoliberalizmus és újliberalizmus ........................ 59

3.1. A klasszikus liberalizmus és a XX. századi liberalizmus közti átmenet .........59

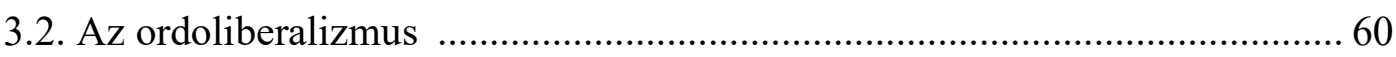

3.3. A klasszikus liberális elvek gyakorlati megvalósulása és az ehhez vezető

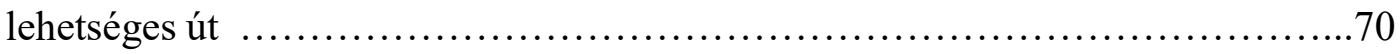

3.4. Liberális állam- és társadalomszervezési alapok az ordoliberálisok elképzelése

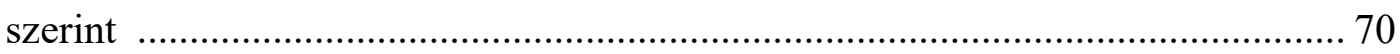

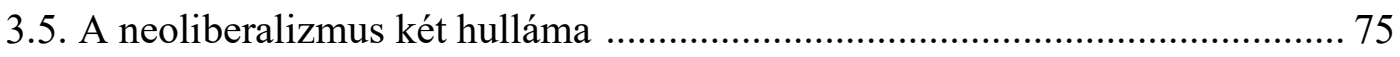

3.5.1. A neoliberalizmus korszakának lezárulása nem jelenti a liberalizmus végét

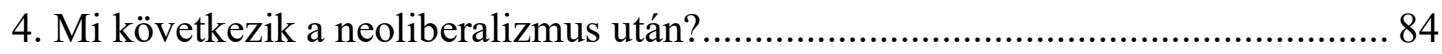

4.2. Ordoliberalizmus és a neoliberalizmus összevetése ................................ 85 
4.2. Ordoliberalizmus számokban - a német gazdasági csoda

5. XXI. századi kihívások: szabadság és szolidaritás, valamint szabadság és biztonság kérdései az Európai Unióban 96

5.1. Világszerte csökkenő szabadság 97

5.2. Új, gyakorlati kihívások és liberális eszmetörténeti fordulópont 102

5.3. Az Európai Unió lehetséges válaszai a fennálló kihívásokra 107

5.4. A liberalizmus feladata az Európai Unió tagországaiban 112

5.4.1. A liberalizmus szükségessége a társadalomszervezésben - a jogállam csorbulása mint közösségi jogsérelem

5.5. A globális gondolkodás és a lokális cselekvés kivételes szerepe

5.6. Az egyéni és közösségi felelősségvállalás megjelenése az Európai Unió következő költségvetési ciklusában

5.7. A koronavírus-járvány okozta gazdasági-társadalmi károk egyik szakpolitikai következménye: a lehetséges európai adóharmonizáció - Lehetséges-e adóharmonizáció az Európai Unióban, és mi lehet ennek hatása?....

Konklúzió

Hipotézisvizsgálat

Zárszó helyett.

Felhasznált irodalom 143 


\section{Köszönetnyilvánítás}

Szeretnék köszönetet mondani azoknak, akik segítettek engem abban, hogy ez a dolgozat elkészüljön. Mindenekelőtt Trautmann Lászlónak, aki témavezetőmként nem pusztán a dolgozat sorainak megírásában vezette a kezem, de úgy segített nekem megismerni egy világot, hogy közben úgy tett, mintha egyedül járnék a felfedezőúton. Köszönöm Szent-Iványi Istvánnak, Petőcz Györgynek, Bodnár Zoltánnak és Sárvári Balázsnak, akik nem csak elméletben, de a gyakorlatban is inspiráltak engem. Köszönöm Ádám Zoltánnak és Wieszt Attilának, akik akkor vállalták el publikációim lektorálását, amikor igazán szorított az idő. Köszönöm Csizmadia Ervinnek, aki elhitte, hogy helye van a sci-finek a Politikatudományi Szemlében. Köszönöm a Világgazdasági Intézetnek, hogy mindig a lehető legjobb időszakokban kaptam tőlük lehetőséget arra, hogy oktathassak, és hogy olyan emberek vesznek köztük körül, akikre felnézhetek. Végül köszönöm Gergely Bencének, aki rendkívül fiatal emberként, az elmúlt években minden nap emlékeztetett engem arra, hogy bár a tudományos életben fontosak a nálunk idősebb és tapasztaltabb kollégáink, de legalább ilyen fontos, hogy azoktól a generációktól is tudjunk tanulni, akik kedvéért kifizetődőnek látjuk a munkát, amit a világ fejlődésére kívánunk fordítani.

\section{A témaválasztás indoklása}

A Budapesti Corvinus Egyetemen tanultam, az első olyan évfolyam tagja voltam, amely a kétszintű érettségi rendszerében tett felvételi vizsgát, és az utolsó, amelynek lehetősége volt nemzetközi kapcsolatok szakos közgazdász-hallgatóként megkezdeni a tanulmányait. Egy olyan nemzedék tagja vagyok, amelynek közös gyermekkori élménye a rendszerváltás utáni bizonytalanság, az ezredfordulót körülvevő zavaros hiedelmek az európai integrációs folyamatokról, a 2001. szeptember 11-i terrortámadás és annak hatása a reálpolitikára, valamint a 2008 harmadik negyedévében bekövetkezett világgazdasági válság és annak minden következménye. Azért vált fontossá számomra a kérdés a liberális eszmerendszerrel kapcsolatosan, mert látom és érzékelem az értékválságot, nem pusztán hazánkban, de a kontinensen és a világban is.

Meglátásom szerint olyan útkeresés közepén van a világ, amelynek megoldása kérdéses, a kimenetelek eredményessége pedig nem garantált. A populizmus harmadik hullámának térnyerése, a II. világháború óta felépített nagy intézményrendszerek és 
nemzetközi szervezetek, közösségek gyengélkedése mind azt mutatja, hogy szükséges újragondolni, újraszervezni a világrend értékrendszerét.

A liberalizmus nem most született, az általa megfogalmazott értékek és társadalomszervezési ajánlat mintegy négy évszázados múltja, ókori görög filozófiában gyökerező mivolta, az emberiség krízisein keresztül fejlődő eszmerendszere a mai napig meghatározza az életünket. Nem először került válságba, és - amennyiben helyesek e dolgozat feltevései - valószínűleg nem is utoljára.

Hiszem és tudom, hogy a liberalizmus alapértékei átgondolatlan államszervezési magatartással, morális válságban leledző közösségekkel már egy olyan kombinációt alkot, amely nem tudja segíteni a társadalomfejlődést. Különösen nehéz ez akkor, amikor legutóbbi eszmetörténeti korszaka éppen ellenkező irányba hatott: vívmányai ellenére olyan folyamatokat indított el, amelyek feszültségekhez, a fenntarthatóság hiányához és igazságtalanságokhoz vezettek.

Hazánk társadalma, kutatások alapján, különösen nehéz helyzetben van. A Tárki minden évben megjelenő értékszerkezeti kutatása ${ }^{1}$ alapján mi, magyarok, nem bízunk egymásban, a politikusokban, de még az intézményeinkben sem. Sokan úgy hiszik, ők maguk becsületesek, a többi ember azonban nem az. Nem tudják elhinni, hogy a kemény munka egyszer meghozza a gyümölcsét, a megkérdezettek többsége beszél arról, hogy az egyéni kapcsolatrendszer dönti el, kinek milyen lesz az élete végül: lényegében nem tudnak hinni az esélyegyenlőségért való küzdelem eredményességében, és a tapasztalatok szerint ebben igazuk is van.

A fentiek értékválságot jelző tényezők, aminek átfogó megoldásjavaslatát egyelöre alig vállalta magára valaki. Jelen dolgozat nem arra vállalkozik, hogy az egész társadalom számára értékképző vagy értékválság-felszámoló írás lehessen, arra viszont mindenképpen, hogy vitaanyagként szolgálhasson a liberális és más eszmerendszereket képviselő gondolkodók számára.

A Föld környezeti, valamint az emberiség társadalmi értelemben vett fenntarthatósága érdekében átfogó és koherens javaslatra van szükség. Az értekezés nem állítja, hogy jelen válság megoldására kizárólag a liberális eszmerendszer keretein belül találhatunk megoldást, azonban amellett érvel, hogy a jelenkor kihívásaira adhatók releváns válaszok a liberális eszmerendszeren belül. Állítja ezen felül azt, hogy mindhárom eszmerendszernek - a liberalizmusnak, a konzervativizmusnak és a

${ }^{1}$ https://www.tarki.hu/hu/research/gazdkult/gazdkult elemzeszaro toth.pdf 
szociáldemokráciának - meg kell tudni újulnia úgy, hogy fel tudjon vázolni egy lehetséges társadalompolitikai ajánlatot, amely releváns válaszokat képes megfogalmazni a jelenkor kihívásaira.

Azért választottam ezt a témát, mert szeretnék hinni abban, hogy az egyre több veszélyt rejtő világban, az egyéni és csoportos szabadságjogok megtartása mellett lehet garantálni a polgárok biztonságát. Azt gondolom, ehhez szükség van liberalizmusra, de egészen más formában, mint ahogyan az eszmerendszer a '70-es évek elejétől kezdve bemutatkozott a nyugati világnak.

\section{BEVEZETÉS}

A három eszmerendszer, a liberalizmus, a szociáldemokrácia, a konzervativizmus mind megújulásra szorulnak. „A nemzetközi társadalomtudomány fö sodrában egyre nyilvánvalóbbá válik, hogy a 2010-es években Új Világrend jött létre, s hogy annak színre lépése szorosan összekapcsolódik a neoliberalizmus válságával, ami meghozta az Európai Unió és az Egyesült Államok értékrendjének, globális szerepének és egész fejlödési perspektivájának elválását és éles szembefordulását." (Ágh, 2019. p. 9.)

A neokonzervativizmussal egy időben megjelenő neoliberális gazdaságpolitika korszaka lezárult, egyelöre azonban erősen hiányos az elképzelés: mi következik a neoliberalizmus után. Erre a kihívásra gazdaságpolitikai téren keres választ a dolgozat. A dolgozatban azt állítom, hogy a liberalizmus nem bukásához, hanem eszmetörténeti fordulópontjához érkezett. A liberalizmus eszmetörténeti újragondolásával, valamint egy lehetséges XXI. századi alternatíva felvázolásával lehetőség nyílik egy új kihívásokra releváns válaszokat találni képes liberális politika kialakítására. Meglátásom szerint a liberális eszmerendszernek abban az esetben van esélye megújulni, ha új fejezete a felelösségvállalást és a közösségi gondolkodást helyezi a középpontba. A dolgozatban a liberalizmus következő fejlődési lépcsőjének megnevezésére az „újliberalizmus” fogalmát használom, a közösségi gondolkodásra pedig az „új racionalitás” fogalmát. (Dardot-Laval, 2013.)

A dolgozatban elismerem a liberalizmus - utolsó eszmetörténeti lépcsőfokának hibáiból eredő - eszmetörténeti válságát, és azt az állítást kívánom bizonyítani, hogy ez a liberalizmus eszmerendszerén belül korrigálható. A megoldást a klasszikus liberális elvekhez és a klasszikus, XVII. századi liberalizmus hagyományához való 
visszatérésben látom, különös tekintettel a Locke-i és Smith-i hagyományra, valamint a humanizmus és az emberi méltóság középpontba állítására a gazdaságelméletben is. A XX. századi piaci és társadalmi kudarcok rámutattak: a piaci fundamentalizmus alkalmazása nem megfelelő rendezőelv. A társadalmat és a gazdaságot szervezni kell - ez a mindenkori gazdaságpolitikai és politikai vezetők feladata. „Az Új Világrend két tényezövel hozható eröteljes kapcsolatba. Egyfelöl a globalizáció újabb szakaszával és ezzel szoros összefüggésben az informatika viharos térnyerésével, azaz a globális informatikai társadalom kialakulásával, másfelöl a tudásgazdaság megjelenésével és $a$ „,jól-lét” (well-being) alapú társadalom versenyfölényével.” (Ágh, 2019. p. 9.) Az új világrend kialakulása közepette különös fontosságot képvisel a társadalom szervezésében vallott elvek csoportja, valamint azok társadalommal való megosztása. Ezek elmulasztásának már a gyakorlatban is megmutatkozó következményei vannak. A globális trend az, hogy az elégedetlen néptömegeknek populista politikusok képesek csak látszólag releváns választ adni az életükben felmerülő kérdésekre, ennek magyarázata nem pusztán az emberiség kihívásaiban, de az eszmerendszerek válságában és válaszképtelenségében is keresendő, „a neopopulizmus maga is voltaképpen a neoliberalizmus globális válságának jellegzetes terméke”. (Ágh, 2019. p. 9.)

A globális világ kihívásaira adott válaszok a világszintű társadalom megléte és az egész emberiségre kiterjedő közösségtudaton, valamint a közösségi felelősségvállaláson keresztül válhatnak hatékonnyá. Ehhez szükséges az egyenlő méltóság elvének egyetemessége, valamint a különböző kultúrák és társadalmi csoportok közti indokolatlan és teljesítményt rontó különbségek felszámolása.

A harmadikutas gazdaságpolitika olyan szemléletet vázolt fel, amely tartalmazta a szociális érzékenységet, elméleti alapját döntően a liberalizmus egalitárius ága adta. A liberalizmusnak ez a populárisabb vonulata, hiszen az esélyegyenlőség jóval szélesebb értelemben vett értelmezéséről, és egyfajta gazdasági esélyegyenlőségről is beszél. A liberalizmus ott vesztett momentumot, hogy nem keresett időben választ a XX. század utolsó, és a XXI. század első évtizedében jelentkező kihívásokra, és most már több évtizedes késésben van.

A politikai értelemben vett föáramtól való elfordulás és a populisták erősödése (Chryssogelos, 2013.) válságtünet, amely alapján egyértelmü, hogy a mérsékelt politikusok és pártjaik a globális kihívásokra sok esetben képtelenek releváns megoldáscsomagot felvázolni - így a társadalom bizalmát sem élvezik, holott az 
elmúlt évszázad legnagyobb társadalmi-politikai vívmányai a politikai mainstreamből érkeztek.

A II. világháború utáni Európa, az Emberi Jogok Egyetemes Nyilatkozatának ${ }^{2} 1948$. december 10-én való elfogadása, a Harmadik Birodalomtól minden értelemben való elfordulás, és az emberi méltóságra, valamint az egyén szabadságára és diszkriminációmentességre alapozott, új európai kontinens megteremtette azt az európai egységet, amelynek végső törekvése a béke közös őrzése, a jólét és a szabadság stabilitása, valamint a totalitárius diktatúráktól való minél nagyobb távolságtartás. Ezzel párhuzamosan született meg a felismerés: az egyenlő méltóság elvének gyakorlati megvalósulásához elengedhetetlen, hogy felszámolják a nélkülözést, és megteremtsék azt a gazdasági feltételrendszert, amelynek keretében egyre szélesebb társadalmi csoportok gyakorolhatják szabadságukat. (Erhardt, 1957.; Röpke in J. Horváth, 2000.)

Ugyanebben az időszakban az Egyesült Államokba hazatérő veteránok a New Deal Amerikájába (Zala, 1986.) tértek haza: egy hadi gazdaságban páratlanul megerösödött, világpiaci értelemben hegemónná váló gazdaság vált a jólét motorjává, amely hamarosan az egyéni és kollektív szabadságjogok, a jóléti stabilitás és a sokszínűség szimbólumaként vált világhatalommá a bipoláris világ nyugati felén. „Tanulmányok, könyvek sorában mutatják ki, miként eresztett gyökeret és szökkent szárba a felismerés, hogy a nép jóléte a köz ügye és az állam kötelessége." - írja Zala Tamás a New Deal szociálpolitikai vetületéről, melyben arra is rávilágít, hogy az USA társadalomszervezői valójában a munkások különböző érdekvédelmi és önsegélyező szervezeteit követve, megteremtve ezzel az állampolgárok bizalmát, létrehozta a jóléti államot. (Zala, 1986. p. 381.)

A biztonsággal párosuló stabil jólét és a háború utáni eufória nem tartott sokáig, az 1960-as évek végén jelentkező, és Ronald Reagan amerikai elnök, valamint Margaret Thatcher brit miniszterelnök hivatali ideje alatt föárammá váló neoliberalizmus és neokonzervativizmus korszaka egy új típusú társadalmat hozott létre. (Harvey, 2000.) Ennek fő oka, hogy a kor technikai és gazdasági feltételei nem tették lehetővé a jóléti állam korszakában, hogy a biztonság és a szabadság közötti összhang maradéktalanul megvalósulhasson, és ezért a jóléti állam kritikájaként nagyobb hangsúly került a szabadságra a politikai irányításban, beleértve a gazdaságpolitikát is. A cél a

\footnotetext{
${ }^{2}$ https://www.ohchr.org/EN/UDHR/Documents/UDHR Translations/hng.pdf
} 
kollektivizmussal való szembehelyezkedés volt, valamint az egyén önmagáért való korlátlan felelősségvállalása és önálló boldogulása vált fő társadalmi rendezőelvvé.

A piaci liberalizáció, az árak kontrolljának megszüntetése, a tőkepiacok deregulációja, kereskedelmi akadályok lebontása, az állami befolyás - privatizáción keresztüli csökkentése, fiskális megszorítás és makroökonómiai stabilizáció, pénzkínálat és monetáris intervenció, államháztartási hiány visszaszorítása, minimális állam és kicsi kormány. Ezek a pontok a williamsoni tíz ponttal (Benczes-Blahó, 2002.) lényegében összhangban vannak, és pontos képet adnak a neoliberális gazdaságpolitikáról. „A Washingtoni Konszenzus 1989 novemberében az amerikai globális világrend szimbólumává emelkedett, nemcsak a tíz pontban a liberalizálás, a deregulálás és a privatizálás mentén összefoglalt gazdasági-pénzügyi szabályozás tekintetében, hanem geopolitikai értelemben is, hiszen ekkortájt omlott össze a duális világrend." (Ágh, 2019. p. 15.) A neoliberalizmus ugyanakkor egy fejlődési modellre is utal, melyben a gazdaságstratégiai tervezés maga a piac szabadon engedése, és a piaci törvények minél tisztább formában való érvényesülése az irányadó. Célkitüzései közt szerepel, hogy az állam szerepét minimálisra csökkentsék, és az egyének szabadságát a lehető legszélesebb értelemben terjesszék ki. (Benczes, 2016.)

Hiába a '70-es évek neoliberális törekvése, amely újjá kívánta építeni az egyes társadalmi csoportok kezében összpontosuló gazdasági erőt, a klasszikus liberális elvektől való elfordulás korszakát jelentette a 2008-ig eltelt negyven év. (Harvey, 2005.). A freiburgi iskola által szorgalmazott aktív állami szerep is kezdett feledésbe merülni, noha az is a liberális eszmerendszer keretén belül megfogalmazott gazdaságstratégiai tervezési elképzelés.

Bár a neoliberalizmus közel sem a piaci fundamentalizmus szinonimája, mégis ezzel azonosítják, holott több társadalomfejlődési modell is kialakult - az USA és az NSZK erre jó példák. A reagani társadalom- és gazdaságpolitika fejlesztette a gazdaságot és a társadalmat, az NSZK pedig megmutatta, hogy a liberalizmus új iránya az emberi méltóság mindenekfölött való tisztelete - ahhoz pedig kell a szociális értelemben vett biztonság, a gazdaság minden szereplöje számára.

Két jól elkülöníthető szakasz látszik kirajzolódni a XX. századi liberalizmus történetében, és ezek egymástól eltérő modellt alkottak a gazdaságirányításban. Az első korszak nagyjából az 1930 és 1960 közötti időszakot fedi, melynek leghangsúlyosabb lenyomatai a német gazdasági csoda, a szociális piacgazdaság és az 
ordoliberálisok (zászlóvivőik Eucken, Erhard és Röpke). E korszak állítása, hogy a gazdaságot nem elég irányítani, szervezni kell. (Dardot-Laval, 2013.)

Elképzelésük szerint az erős jogrendszer és a jól szabályozott piac képes jó mederben terelni a gazdaságot és meghozni a gazdasági fejlődést. (Erhardt, 1957.) Ők voltak azok, akik kimondták: a Smith-i értelemben vett éjjeliőr-állam nem elég. A II. világháborút követő időszakban, az NSZK-ban megvalósuló szociális piacgazdaság elméleti alapjait részben liberális gondolkodók és közgazdászok adták.

A második szakasz, amelyet a tudomány neoliberalizmusnak nevez, a '70-as évek közepétől induló új hullám, amelyet már a privatizáció, a piaci liberalizáció, a dereguláció és az állami újraelosztás minél kisebb mértéküre zsugorítása jellemez. A neoliberálisok jól fejlett jogállamot támogattak - ebben nem tértek el ordoliberális féltestvéreiktől. (Venugopal, 2015.) A Mont Pelerin Társaság és a Chicago-i iskola olyan gazdasági modellt teremtettek, melyet aztán az USA katonapolitikai védőernyője alatt, az egész világon, diktatúrákban is elterjesztettek. (Harvey, 2005.) Végső soron nem a jogállam bontakozik ki a neoliberalizmusból, hanem a technológiai modernizáció.

Ugyan a neoliberalizmus alapvetően segíti a jogállami normákat, de az elmúlt harminc évben olyan rendszert teremtett, ami nem fér össze a jogállami normákkal. A neoliberalizmus társadalmi szakadékmélyítő hatása (Harvey, 2007.) a rosszabb anyagi helyzetben levő rétegektől elvette az önmegvalósítás lehetőségét, azok számára pedig, akik viselkedése piackompatibilis volt, és akik jólétben tudtak élni, a teljesítménykényszerbe való bezáródás csapdáját teremtette meg. „A neoliberalizmus e piaci fundamentalista programnak az a specifikus formája, amelyet az 1947-ben alapított Mont Pelerin Társaság meghatározó alakjai - mindenekelött Friedrich Hayek és Milton Friedman - inditottak útjára, és amely az 1970-es években vált meghatározó gazdaságpolitikai áramlattá, a 20. század végén lényegében globális hegemóniára tett szert." (Kapelner, 2019. p. 94.)

A szabadság leple alatt egy olyan társadalom épült, amely minden társadalmi csoportot másként érintett rosszul. Nem a liberális értékek voltak fontosak, hanem az egyéni szabadság. (Harvey, 2007.) „Alapvetően, amikor neoliberalizmusról beszélünk, egy olyan politikai, gazdasági és társadalmi berendezkedésre utalunk, amely a piaci viszonyokra, az állam feladatainak újragondolására és az egyéni felelösségre helyezi a hangsúlyt." (Kapelner, 2019. p. 9.) Az a társadalmi csoport, amely a neoliberalizmus emberképe szerint „helyesen” cselekedett, és nagy piaci teljesítményre volt képes, a 
szabadidejének feláldozásával fizetett a piaci pozíciójáért. A társadalom alsóbb rétegei pedig elestek az esélyegyenlőségtől, nem tudtak kitörni a társadalmi rétegből, amelybe beleszülettek. Ennek oka az volt, hogy a neoliberalizmus társadalomszervezése nem tette lehetővé a társadalmi mobilitást. (Dardot-Laval, 2013.) A neoliberálisneokonzervatív fordulat gondolatiságából következett az is, hogy az alsóbb társadalmi csoport tagjait széles közvélekedés alapján bélyegezték morálisan alsóbbrendünek, ezzel végérvényesen szakítottak el egymástól társadalmi csoportokat. Ezek a gazdaságirányítási rendszerből adódó szerepek azonban ellentmondanak a klasszikus liberalizmus emberképének. (Szentes, 2006.)

Az eszmerendszer emberképe - vagy eredetileg megalkotott emberképe - nem volt koherens a neoliberalizmus által képviselt gazdaságpolitikai irányvonallal. Bár a szabadság védelme érdekében kezdődött el a gazdaság átalakítása, de visszatekintve jól látható, hogy ez a szabadság nem tudott megvalósulni, ezért a neoliberalizmus kritikusai joggal jegyzik meg, hogy ez a korszak végül olyan világot teremtett, amelyben már nem a szabadság társadalmát építették, hanem a vállalatok érdekében cselekvő, teljesítménykényszeres menedzserekét. (Dardot-Laval, 2013.)

Az emberi méltóság mindenekfölött való tisztelete és az egyenlő méltóság elve, amit a klasszikus liberális elvek huszadik századi alapvetésként teremtettek, nem tudtak érvényesülni a neoliberalizmus időszakában. A liberális teoretikusok egy csoportja azonban azt állítja: az egyenlő méltóság elve az, amelyen „a minimális állam melletti robosztus érv elbukik”. (Kis, 2015.) A neoliberalizmus korszaka egy sok tekintetben szolidaritáshiányos, szélsőségesen individualista, közösségi felelősségvállalást nélkülöző társadalmat szervezett. A klasszikus liberális gondolkodók számoltak azzal, hogy a spontán piaci folyamatok számos olyan tökéletlenséget hordoznak, amely társadalmi igazságtalanságokhoz, és nagyszámú embercsoportok méltóságának sérüléséhez vezet. (Szentes, 2006.)

A közösségszervezésre is negatívan hatott a neoliberalizmus, és erősítette az individualizmust. A neoliberalizmus egyenlötlenségeket okozott, de nem talált megoldást az enyhítésére - igaz: nem is keresett. A neoliberalizmust sokszor úgy írják le, mint egy radikális lassez faire tapasztalatot, pedig eredeti elképzelések szerint arról szól, hogy hogyan kell szabályozni a piacot, hogy az jól müködjön. A piaci liberalizációs politika lerombolta a háború utáni keynesiánus konszenzust és a jóléti államot. Egy olyan világot épített helyette, amelyben a biztos jövedelmet nyújtó, 
nyolcórás munkát sokak számára a temporálisan létező munkahely, vagy a részmunkaidő váltotta fel. (Dardot-Laval, 2013.)

Az ilyen irányú gazdaságstratégiai váltás azért is lephette meg a világot, mert még a republikánus Nixon is kimondta: mind keynesiánusok vagyunk. (Harvey, 2005.) A jóléti állam lerombolása ugyan egyéni szinten sok esetben okozta egzisztenciák összeomlását, a neoliberális gazdaságpolitika fellendítette a gazdasági növekedést mind az USA-ban, mind számos, korábban fejlődő, mezőgazdasági országban, amelyben a gazdasági szerkezetváltást is segítette. (Venugopal, 2015.) A neoliberalizmus '70-es években megerősödő vonulata „a társadalmi szolidaritás minden formáját támadta" (Harvey, 2007. p. 23.), és akadályozta az esélyek kiegyenlítődésének megvalósulását. „A neoliberálisok a szociális és politikai liberalizmus képviselöivel versengtek a kapitalista világrendszer uralásáért." (Antal, 2019. p. 115.) A Ronald Reagan és Margaret Thatcher által uralt korszak ugyan egy jobboldali politikai ideológiai áramlatot képviselt, melynek keretében „valójában a lassez faire kapitalizmus és a kulturális konzervativizmus összeolvadásának" volt szemtanúja a világ, itt azonban nem állt meg - írja Heywood (2003), mert mind a szociáldemokrata, mind a liberális pártokra erős hatást gyakorolt. Így vált a neoliberalizmus az euroatlanti térségben politikai hegemónná, ezen keresztül pedig a globalizált kapitalizmus ideológiájává. (Heywood, 2003.)

Számos cikk születik és született a neoliberalizmusról, azonban definíciót elvétve találni. A legtöbben azt írják: “neoliberalizmus, ahogyan én látom”. Nagyjából 1000 cikk jelent meg 2002 és 2005 között a neoliberalizmusról évente (Boas - Gans-Morse, 2009.), mégsem rajzolódik ki egy konszenzuálisan alkotott definíció, amelyet végül mindenki el tud fogadni. Eddig viszonylag csekély volt a törekvés arra, hogy létezzen, azonban jelen dolgozat részét kell, hogy képezze egy meghatározás, ezért az alábbi definíciót alkottam.

A neoliberalizmus az 1970-es években megerösödö gazdaság- és társadalompolitikai újhullám, amely új válaszokat adott arra a kérdésre, hogy hogyan kell szervezni a társadalmat. Gazdaságpolitikáját a minimális állam és dereguláció, valamint az árupénz és tőkepiacok liberalizációja jellemezte, társadalompolitikája az egyéni szabadságot hangsúlyozta, ugyanakkor nélkülözte a szolidaritást és a közösségi felelösségvállalást, ezen keresztül pedig a szándékot is, hogy megakadályozza a leszakadó társadalmi rétegek ellehetetlenülését. A piac önszabályozó mechanizmusai 
és a piaci szereplök racionális viselkedése mellett tesz hitet, emberképe a saját gazdagodását önerőből elérni képes egyén, aki élni tud szabadságával. A társadalom azon szereplöit, akik erre önerőböl képtelenek, morálisan alsóbbrendünek tartja, ezzel megerösitve a törésvonalat, amelyek a társadalom gazdagabb és szegényebb rétegei közt húzódnak.

A neoliberalizmussal szövetséget kötő neokonzervativizmus definícióját is csak elvétve vagy részlegesen találjuk meg, e dolgozat sem tehet úgy, mintha a '70-es években megkezdődött euroatlanti és globális folyamatok kizárólag a neoliberalizmus lenyomatai lennének a társadalomban. Éppen ezért az alábbiakat tekintem a neokonzervativizmus definíciójának:

A neokonzervativizmus a konzervatív eszmerendszeren belüli forradalomként fogható fel, amely az 1960-as évek Amerikájára adott ellenforradalomként is értelmezhetö. Radikális antikommunizmus jellemezte, mely megmutatkozott külpolitikai, társadalompolitikai és közgazdaságtudományi értelemben is. Alapvetően motiválta az USA társadalmának hagyományos értékekhez való visszatérésének elömozditása, valamint az, hogy a növekedést és a társadalom egyes tagjainak boldogulását a New Deal politikája nélkül, a munkapiacra és a piaci folyamatokra alapozza. A totalitarizmussal szembeni erös fellépés és a demokráciavédelem jellemezte, ebböl eredöen tette morális kérdéssé a bipoláris világ felbomlását, de azt is, hogy a nemzetgazdaság müködésébe ne engedje be az egalitárius eszmét.

Adódna a kérdés, hogy a neoliberalizmus miért a neo-konzervativizmussal találta meg a közös nevezöit, de a fenti két definíció alapján ez a kérdés könnyen megválaszolható. A piaci szabadság feltétlen híveinek számító liberálisok éppen ugyanúgy elutasítottak a korszakban mindennemü állami beavatkozást, mint ahogyan a polgárok szabadságának vagy a demokratikus értékek megsértését, akár a korszak konzervatívjai. A neoliberális-neokonzervatív szövetségkötés olyan természetesnek hat mindezek fényében, hogy a közösen létrehozott társadalomszervezési alapelvek és gazdaságstratégiai tervezési irány szinte kiválogathatatlanná teszi, hogy a '70-es '80as évek gazdasági-társadalmi folyamatainak mely építőkockái származtak a neoliberálisoktól, és melyek a neokonzervatívoktól. 
A pont, amikor a liberálisok a konzervatívokkal kerültek egy platformra, az 1929-es nagy gazdasági világválság utáni időszakra, a múlt század '30-as éveire és a második világháború idejére tehető. Kezdett filozófusok, közgazdászok és gazdaságstratégiai tervezők számára releváns - és többek szemében egyedüli - jó megoldásnak tünni a szocialista tervgazdaságra való átállás, azonban egy akkor még fiatal közgazdász, Friedrich August von Hayek nagy veszélyt érzékelt ebben, és azt állította: a tervutasításos rendszerre való átállás előbb-utóbb szolgává teszi a polgárokat.

John Maynard Keynes is a lassez faire vége mellett érvelt, mialatt Friedrich A. Hayek meg volt róla győződve, hogy a nagy gazdasági világválságnak monetáris okai voltak, a filozófusok és gazdasági szakemberek többsége a liberális kapitalizmus kudarcaként interpretálta a történteket. Mindenki számára nyitott kérdés volt, hogy a társadalomszervezési alapelvek melyik gazdaságstratégiai tervezés mellett tudnak még müködni.

A harmincas éveken nem pusztán akadémiai körökben, de politikai síkon is tovább folyt a vita, hogy a liberalizmus totális bukása következett-e be a húszas évek végén. Mindeközben 1933-ban Adolf Hitler kancellárrá vált, és nem pusztán közellenségnek kiáltotta ki a liberálisokat és demokratákat, de megkezdődött az értelmiség és zsidó üzletemberek bebörtönzése is, valamint elkezdődtek a könyvégetések. Nem pusztán gazdasági kérdés volt tehát a liberalizmus megmaradása, de olyan civilizációs alapelvek fennmaradásáért is felelős lett, amelyeket a Harmadik Birodalom a földdel tett egyenlővé, nélkülük azonban elképzelhetetlen lett volna a német társadalom fasizmus utáni időkben való újjászervezése és újjáépítése.

A fasiszták a kapitalista rendszert támadták, nem pusztán a liberális társadalomszervezési alapelvekkel akartak végezni, de a gazdaságstratégiai tervezéssel is. Ez egészen odáig fajult, hogy a nácik propagandaminisztere, Göbbels nyílt levélben fordult a kommunistákhoz, és azt állította, hogy a nácik és a kommunisták gazdaságstratégiai tervezési elvekben igen hasonlóak egymáshoz, így ennek a két irányzatnak be kellene fejezni az egymással való harcot.

Ezekben az években a brit Munkáspártban is erősödött a radikalizálódás, és többen a szocialista tervgazdaságban látták az akkori gazdasági-társadalmi válság megoldását. Széles körben elterjedt gondolat volt akkor már politikai hovatartozástól függetlenül, hogy a „társadalom tudományos tervezése” lehetséges, és sokkal nagyobb jólétet, többek boldogulását segíti elő, mint a lassez faire világa. (Caldwell, 2020.) Hayek éppen emiatt a társadalompolitikai újhullám miatt írta meg „Út a szolgasághoz” 
(1944.) című mủvét, amelyben kifejti álláspontját a nagy gazdasági válság mibenlétéről, és arról, hogy a szocialista tervgazdaságban mindenkire szolgaság vár. A liberálisok ebben az időszakban többfrontos háborút vívtak. Nem pusztán a fasizmus, de a kommunizmus is eltaposni igyekezett az addigi jogállami és szabadelvü vívmányokat. Azzal érveltek, hogy a „monopolitsztikus kapitalizmus jóléti egyenlötlenségeket hagy maga után, ami azt eredményezte, hogy a piac olyan javakat állitott elö, amelyek a gazdagok keresletét kielégitették, de a társadalmi igényeket nem teljesitették”. (Caldwell, 2020. p. 726.) Ezekre a kihívásokra számos akadémikus azt a választ adta, hogy az egész kapitalista piacgazdaságot hátra kell hagyni, és el kell fordulni a társadalom tudatos és tudományos tervezése felé. Úgy gondolták, hogy a „lehetséges legnagyobb jólét” előállítása csak a szocializmus keretrendszerén belül létezhet (Blackett in Hall et al. 1975 (1935) p. 144.).

Az, hogy a „tervezett társadalom konstrukciója” jövőkép szempontjából a nyugati világban is egy ténylegesen komolyan vett és megerösödött újhullámmá vált, nagyban volt köszönhető annak, hogy a piacgazdaság mindenki által látott hibáit nem kijavítani igyekeztek, hanem az egész keretrendszert lecserélni.

Harold Laski a '30-as években rendkívül gyorsan radikalizálódott, nagyon erösen megjelent nála a marxista irányzat, úgy az akadémiai munkáját, mint a politikai szerepvállalását tekintve. A magyar emigráns Karl Mannheim is azt állította, hogy a liberalizmus halott, és a társadalom tervezésére van szükség. ,A liberálisok ezekben az években tipikusan az emberi jogok univerzális nyelvén keresztül igyekeztek védeni saját álláspontjukat. Hivatkoztak még a tulajdon szentségére és a szerzödések szabadságára, valamint a tőkefelhalmozás támogatására." (Cadwell, 2020. p. 729.) A liberális eszmerendszer tér- és momentumvesztése eredményezte a már hivatkozott Lippmann-konferenciát 1938 nyarán, Párizsban, ahová a kontinens számos gazdasági, jogi és társadalomtudományi szakembere hivatalos volt. Ez a rendezvény valójában egyfajta előőrse volt az 1947-ben megalapított Mont Pélerin Társaságnak.

A brit szocialisták a jóléti államot célozták meg szociális juttatásokkal a családok részére, általános társadalom- és egészségbiztosítási rendszerrel, valamint teljes foglalkoztatottsággal. (Beveridge, 1942.) Hayek válasza volt a baloldali brit értelmiség számára az „Út a szolgasághoz” címü könyv, amellyel a liberalizmus megmaradása mellett érvelt annak érdekében, hogy belássák: a szocialista tervgazdaság kialakítása előbb-utóbb - bármilyen tisztességes vezetők, bármilyen stabil intézményrendszer és bármilyen jószándék megléte mellett is - totalitárius rendszert hoz egy társadalom 
életébe. Hayek gondolata a „tervezés a versenyért” elv volt. (Dacwell, 2020. p. 735.) Hayek a „szabadságról és a gazdasági rendröl”, valamint a „tervezésröl és a demokráciáról" írt, utóbbi fejezetben arról értekezett, hogy milyen nehézségei támadnának egy demokráciának, ha központosított tervutasításos rendszert próbálna működtetni. Hayek megfogalmazásában egy „teljes etikai kódexnek” kell léteznie, ami lehetővé teszi a sikeres tervezést. (Hayek, 2007 (1944), p. 101.)

Természetesen Hayek nem a jóléti államot támadta, hanem a tervutasításos szocialista rendszert. Nehéz dolga volt, mert 1944-ben a szovjetek még a britek szövetségesei voltak a II. világháborúban, és közösen harcoltak a nácik ellen. Keynes levelet írt 1944 nyarán Hayeknek Atlantic Cityből, amelyben azt állította: „,arról próbálsz meggyőzni minket, hogy ha akár egy tapodtat is elmozdulunk a tervezés irányába, már rá is léptünk arra a csúszós ösvényre, amiröl a szakadékba zuhanunk”. (Keynes Hayeknek, 1944. június 28-án, in Keynes 1980. (1944.) p. 386-387.) A következő években sokan értették még hasonlóan Hayeket, mint Paul Samuelson, aki egy ponton kérdőre vonta Hayeket, hogy egészen pontosan mifelé is vezet az az út, amelyről beszél. A skandináv országokat hozta példának, és konkrétan rákérdezett, hogy hol vannak az ő „horror táboraik” (a gulágjuk) és a centralizált hatalomgyakorlásuk. (Samuelson, 2009.)

Valójában Hayek a lehetséges veszélyekre hívta fel a figyelmet, és leírta, hogy mi lehet egy országban a következménye, ha a szocialista tervgazdaság elvein elindulva tervezik a gazdaságot. Az „Út a szolgasághoz” című könyv azonban az idők során jelentős transzformáción ment keresztül. Egy közgazdasági figyelmeztetésből a II. világháború utáni világban a hidegháború egyik irodalmi ikonjává vált. (Caldwell, 2020.) Nem meglepő módon a konzervatívok voltak azok, akik találtak benne egy ügyet. „Olyan volt számukra a könyv, mint a mennyei manna.” (Cockett, 1995. p. 91.) Így vált az 1945-ös választások egyik szereplőjévé Hayek: Winston Churchill úgy döntött, hogy nekitámad a Munkáspárt balszárnyának. Eddigre már az eredetileg liberálisan gondolkodó Harold Laskit is „,örös professzor”-nak nevezték, a két oldal egyre hevesebb vitákat vívott az elméleti gazdaságtan síkján, azonban több mint valószínü, hogy a háborús hős Churchill - aki kétséget kizáróan olvasta a könyvet, és épített rá a beszédében - túlzóan fogalmazott, amikor azt mondta, hogy egyetlen szocialista rendszer sem létezhet politikai rendőrség nélkül. A később „Gestapo beszédként" elhíresült gondolatok taktikai hibának bizonyultak, a Munkáspárt fölényesen nyerte meg a választást, a konzervatívok visszaszorultak, a liberálisok pedig mindössze tizenkét mandátumot szereztek a következő brit parlamentben. 
A kérdés, hogy létezik-e teljes foglalkoztatottság és szabad társadalom egymás mellett, éveken át foglalkoztatta a tudományos és politikai közeget. Időközben Hayek médiaszenzáció lett, és az USA-ban talált kutatótársakra. Hayek az '50-es években egyre nagyobb szükségét érezte, hogy távolságot tartson a konzervatívoktól, akikkel egyébként vitán felül állt a közös platform, ha az antikommunizmusról vagy a kollektivizmus elutasításáról volt szó, azonban 1960-ban mégis szükségesnek tartotta hangsúlyozni, hogy ő maga miért nem konzervatív. Hayek az azt követő években is aggódott a szocializmus miatt, azonban 1960-ban publikált cikke, „A szocializmus visszaszorulása és a jóléti állam felemelkedése” (Hayek, 2011 (1960) p. 369-83.). Bár a Nyugat-Európában lezajlott politikai és gazdasági folyamatok nem igazolták vissza a jóléti államtól való félelmét, mindvégig amellett érvelt, hogy a jóléti állam hordozza magában az indokolatlan állami beavatkozás veszélyét.

Hogy mennyire releváns és sokakat foglalkoztató kérdés volt a múlt század derekán, hogy vajon a jövőben az egész világ a totalitárius rendszerek martalékává válik, mert egyre több helyen a polgárokat minden értelemben központi irányítás alá vonni igyekvő erő kerül hatalomra, azt George Orwell 1949-ben megjelent disztópiája, az 1984 mutatja talán a legjobban.

A reagani kommunikáció sikeressége részben abban rejlett, hogy egyetlen üzenettel a hazai társadalomban is megnevezte azokat, akik a kor „legjobb” emberei, valamint külpolitikai értelemben is. A morális felsőbbrendüség használata a jómódú, önálló életet és jólétet építő polgárokra, valamint a nyugati világra is vonatkozott. Nyilvánvalóvá vált tehát: a körön kívül találjuk a Szovjetuniót és a komplett keleti blokkot, valamint azokat, akik a piaci folyamatok vesztesei voltak az USA-ban.

Ezzel a kommunikációs nyomással egyidőben, a Ford és a Rockefeller Alapítvány arról is gondoskodott, hogy a neoliberális gazdaságstratégiai és társadalomszervezési elvek a vasfüggöny keleti felén is megjelenhessenek, különböző konferenciákon, ösztöndíjasokon és diákcsereprogramokon keresztül. (Bockman 2011. p. 62-63.) Ennek eredményeként Johanna Bockman azt tapasztalta, hogy a vasfüggöny keleti felén, Budapesten olyan közgazdász professzorokat talál, akik olyan pozitív képet festenek a szabad piacról, ami az Egyesült Államokban csak a jobboldaliakra jellemző. (Bockman, 2011. VII. fejezet) Mindenkinek, aki nem képezte a morálisan felsőbbrendűnek titulált társadalmi csoport részét, dolgoznia kellett, hogy bekerülhessen oda. Így morális kérdéssé tette az állam szociális felelősségvállalásának minimálisra csökkentését, valamint a vasfüggöny lebontását is. 
A bipoláris világ felbomlásával egy új típusú világrend kialakulása kezdődött meg: a globális partnerség kultúrája. A mikroökonómiai és makroökonómiai értelemben is megújult korszellem minden elemében mást hozott a neoliberális elvekhez képest. A '70-es években megkezdődött, fokozódó és sok esetben egészségkárosító munkapiaci verseny, a sikeres ember látszólagos morális fölénye (és az egzisztencia elvesztésétől való félelem miatt érzett folytonos szorongásból adódó teljesítménykényszer), a bizonytalanná váló munkaszerződések, a lerövidült munkahetek időszakát egy új világtrend kezdte leváltani. (Dardot-Laval, 2013.) „A neoliberalizmus felemelkedését és hanyatlását egyaránt a kapitalizmus válságai inditották el. A neoliberális hegemónia korszaka hozzávetölegesen a tőkés világgazdaság 1973-as olajválságával vette kezdetét, majd a 2008-as pénzügyi válság zárta le.” (Éber, 2019. p. 128.)

Vannak, akik a technológiai fejlődést értelmezik kapitalizmusként, és ennek fényében kritizálják a piaci kudarcok miatt a neoliberalizmust, holott a technológiai fordulat végső soron segíti a jogállami normákat, a probléma a neoliberalizmussal az, hogy rossz eszközökkel akart teljesítményre ösztönözni. A XXI. században van arra lehetőség, hogy ez megváltozzon.

A fentiekkel szemben, a XX. századi liberalizmus német leágazása, a freiburgi iskola éppenhogy egy stabil, modern jóléti államot hozott létre, szem előtt tartva a fenntartható fejlődést, amely a modernizációt és a társadalom széles rétegeinek felemelkedését is magával hozta - tette mindezt az emberi méltóság mindenekfölött való mivoltának elsődleges értékké emelésével. (Grundgesetz für die BRD, 1949.) A gazdaságirányítási rendszereknek, a gazdaságpolitikai döntéshozóknak és társadalomszervezőknek mindenkori feladata, hogy a kor kihívásaira releváns válaszokat adjanak.

A neoliberalizmus a '70-es és '80-as években a kollektivizmustól való távolságtartást, az egyéni felelősségvállalás fontosságát, az egyéni boldogulást helyezte középpontba, így jelentősen hozzájárult a nemzetgazdaság fejlődéséhez. Külpolitikai téren nyilvánvalóvá tette a Kelettel való hidegháborús viszonyt, és a kollektivizmustól való radikális elfordulást. Az ezredfordulót követően kezd megmutatkozni a globális partnerség mikroökonómiai és makroökonómiai leágazása is. A munkaadó partnerséget ajánl a munkavállalónak, lojalitásért cserébe. A vállalatok rájöttek, hogy a munkaerő alacsony bérekért és számukra előnytelen szerződési feltételek mellett való foglalkoztatása azt eredményezi, hogy a munkavállaló személytelenül, sőt, ellenszenvvel viszonyul majd saját munkáltatójához. Ebben az esetben 
termelékenysége sem olyan magas, mintha a vállalati kultúra részeként a partnerség vezérli munkáltató és foglalkoztatott viszonyát. Fontos tényező, hogy a munkavállaló hozzászólhat a stratégiai tervezéshez, vagy ha olyan szolgáltatások elérhetőek számára a munkahelyén, mint a kikapcsolódás vagy akár a postai szolgáltatások helyben való igénybe vétele.

A makroökonómiai korszellem tetten érhető az aid for trade ${ }^{3}$ koncepciójában. A Szovjetunió és a keleti blokk által hordozott torz gazdálkodási kultúra leomlása után ugyanis nyilvánvalóvá vált a globalizáció felgyorsulásával, hogy a leszakadók segítése az egész világpiac számára kifizetődő. Nem pusztán a nemes gondolat hajtja a kereskedelem beindításáért nyújtott nemzetközi segélyeket, miszerint segítenük kell az elesetteken, hanem az a közgazdasági értelemben vett tény, hogy amennyiben egy adott társadalomban tömegek élnek nyomorban, az ország képtelen a progresszivitás útjára lépni. (Smith, 1776.) E gondolat világszintü leképződése megjelenik a globális partnerség szemléletében.

A vállalatok, a fogyasztók és a munkavállalók szintjén végbement korszellem-változás tehát nem állt meg a mikroökonómia határainál: a fejlettebb országok annak érdekében kezdtek el segélyezni korábban kisebb és gyöngébb gazdaságokat, hogy kereskedhessenek velük, ezáltal pedig maguk küzdhessenek meg egy gyorsabb ütemü gazdasági növekedésért. A partnerség korszaka itt is egy olyan új egyensúlyt teremtett, amelyben a fejlettebb Nyugat arra is használja gazdasági erejét, hogy felzárkóztatási lehetőséget nyújtson a perifériának.

A leszakadás lehetősége ma is jelen van. A gyorsan változó világban szakmák tünnek el, vagy akár komplett gazdasági szektorok vesztik értelmüket egy új innováció miatt. A költségoptimalizálás folytonos lehetőségkeresése azt eredményezi, hogy akár ezreket foglalkoztató gyárak hagynak el nemzetgazdaságokat egyik napról a másikra. Ezek a gazdasági jelenségek súlyos társadalmi következményeket teremtenek, amelyek az innovatív, partneri légkört kialakító vállalatoknál dolgozó munkavállalók számára sokszor láthatatlan, ugyanakkor ez segítheti felzárkózásukat, a szabadság megélésére, kreativitásra ösztönöz.

A szerencsésebb társadalmi rétegek alacsonyabb jövedelmüek felé érzett közönye, a Maslow-piramis tetején leledző önmegvalósítók szemellenzője eljuttatta a társadalmakat oda, hogy a ,fejlett Nyugat" - sok esetben hamis - képzete egy

\footnotetext{
${ }^{3}$ https://www.wto.org/english/tratop_e/devel_e/a4t_e/gr19_e/gr19programme_e.htm
} 
párhuzamos valósággal párosult. A leszakadók valóságával, akik már abból a jövedelmi kategóriából is kiszorultak, amely lehetővé teszi számukra, hogy éljenek saját szabadságukkal, hatásuk legyen saját sorsuk alakítására, vagy legalább azt elérhessék, hogy gyermekeik ne örököljék tőlük a nyomort.

Ha a neoliberalizmus 2008-as „törésteszten” való rossz teljesítménye nem volna elég, úgy tünik, gazdaságstratégiai és társadalomszervezési ajánlata a XXI. századi gazdasági folyamatok zavartalan „közúton haladására” sem elegendő. A neoliberalizmus elvesztette eszköztárát arra, hogy szolgálhassa a társadalomfejlődést. Ennek egyenes következménye, hogy korszaka lezárul.

A realista iskola szerint az emberek természetes állapota az egymás elleni harc, az emberi természet nem változott a történelem kezdete óta, az ember természeténél fogva harcol, leigáz, megaláz mindenkit, aki gyöngébb nála. Az idealisták ugyanakkor hisznek abban, hogy az ember fejlődik, nevelhető, fejleszthető, ezen keresztül a társadalom is fejlődik, és hogy a komplex interdependencia a különböző társadalmak fejlődésén és ezek összeköttetésein keresztül eljuttatja az emberiséget egy magasabb szintre. (Egedy, 2011.)

Az euroatlanti térség számos kezdeményezése mutatja, hogy az európai, valamint az észak-amerikai kultúra fejlődésében nagy szerepet játszik az idealista iskola alaptézisén nyugvó hit, hogy létre lehet hozni egy jobb, szolidárisabb, szabadabb, békésebb társadalmat. Egyik példája ennek a nyugati szövetségi rendszer és az Európai Unió. Az Unióban a kohéziós és fejlesztési alapok már azt a globális partnerséget modellezik a kontinensen, amelyre nagy szükség lenne világszinten is. A népnyelv úgy fogalmazna: az EU nem halat ad, hanem horgászbotot, és ezzel arra készteti a leszakadókat, hogy vállaljanak felelősséget saját fejlődésükért - a regionális és kohéziós alapokból származó források ugyanakkor lehetőséget teremtenek arra, hogy forráshiány esetén, lehetőség fennállása esetén is megvalósulhasson fejlesztő beruházás.

Több cél feszül egymásnak, amelyek együttes teljesülése lehetetlen. Piacbarát rendszer felállítása olyan módon, hogy közben az államot kivonjuk a piacszervezési feladatokból, nem elképzelhető. Az elvárás, hogy feleljen meg az emberi méltóság és az egyenlő méltóság elve szolgálatának a hatalom (Kis, 2015.), miközben olyan piacgazdaságot teremtett, amely elmélyítette a társadalmi szakadékokat, milliókat hozott méltatlan anyagi helyzetbe, elképzelhetetlen. (Dardot-Laval, 2013.) 
Az eszmetörténet választ tud találni arra, hogy a neoliberális korszak miért nem hozta a klasszikus liberalizmus társadalomszervezésében megjelenő alapelvek teljesülését. „A neoliberalizmus nincs összhangban a közgazdaságtan liberális hagyományával”. (Szentes, 2006.) A klasszikus liberalizmus filozófusai és közgazdászai korántsem vetették el az állami beavatkozást, pusztán azokat az állami beavatkozásokat tartották ördögtől valónak, amelyek csorbították az egyén szabadságát, és ezen keresztül felvetették a zsarnokság kialakulásának lehetőségét. Ha úgy tetszik: Smith, Ricardo, Mill és Malthus nem az egyén pénztárcáját, hanem az egyén szabadságát féltették az államtól.

Szentes Tamás (2006) is úgy vélekedik, hogy a XXI. században nem az állam „mérete” a kritikus kérdés, hanem az, hogy az állam hatékony és demokratikus legyen. Ez a kritérium a good governance elvével rokon, amely kimondja, hogy az államnak rajta kell tartania a gazdaságon a szemét, és mindig az aktuális társadalmi igények szerint korrigálni a piaci tökéletlenségeket. (Dardot-Laval, 2013.)

A társadalmon belüli partnerség tanulása az új évezred egyik legnagyobb kihívása. A társadalmi mobilitás hiánya, az öröklött esélyegyenlőtlenség, a generációk óta munkanélküliséggel szembenéző régiók és társadalmi csoportok azt mutatják, hogy olyan iskolára van szükség, amely orvosolni tudja ezeket az évtizedek óta fennálló kihívásokat. Az új cél a közösen megteremtett, mindenkit egyformán megillető emberi méltóság és az egyéni, valamint a közösségi felelősségvállalás. A fentiek taníthatók, ezért a neveléselméletben és a társadalomszervezésben bekövetkező fordulat megteremtheti az új társadalmi rend alapjait.

Az állam feladata és a célja is adott, a kérdés, hogy milyen eszközzel lehet azoknak az elesett társadalmi rétegeknek segítséget nyújtani önmaguk fejlesztésében, amelyeket a neoliberalizmus és a neokonzervativizmus az esélyegyenlőség hiánya miatt, reménytelenül hagyott leszakadni. Ez az eszköz az oktatás.

A felzárkóztatási program maga az iskolarendszer és a neveléselmélet megújulása, az új gazdaságpolitikai irány a gazdaság szervezése, valamint egy jó szabályrendszer kialakítása, melynek medrében a piacgazdaság zavartalanul folyhat - megtisztítva a piaci tökéletlenségektől. Fontos felismerés, hogy a piac humánus értékeket nem szolgál (Röpke in J. Horváth, 2000.), ezt az eredetileg ordoliberálisok által képviselt elvet követve megoldhatóvá válnak azok a kihívások, melyekre a neoliberalizmus már nem képes válaszokat találni. A neveléselmélettel és az iskolaszervezéssel a dolgozat 
- terjedelmi korlátok okán - nem foglalkozik részletesen, az eszmetörténet és a gazdaságstratégiai tervezés felöl közelíti meg a társadalomszervezési ajánlatokat.

A dolgozat állítása az, hogy a klasszikus liberális, valamint az ordoliberális hagyományokhoz való visszatérés elhozhat egy új korszakot a liberalizmus eszmetörténetében. Ez a korszak újragondolt társadalom- és emberképpel, koherens gazdaságirányítási szabályrendszerrel és új neveléselméleti elemekkel képes megalkotni az új liberális emberképet, a „fegyelmezett önmegvalósitót” (DardotLaval, 2013.), és a jelenleg megoldhatatlannak tünő globális problémákra releváns válaszokat ad.

Ahhoz, hogy létezhessen, vagy megerösödhessen a liberalizmus új fogalma, szükség van ,fegyelmezett önmegvalósitókra", ez a fogalom, vagy ennek a szoros megfelelöje gyakorta jelenik meg a liberálisoknál, így Hayeknél és a Friedman házaspár közös művében is, ahol az önfegyelemben látják a jól müködő társadalom zálogát. A „kockázat társadalma” (Dardot-Laval, 2013.) képes nevelő hatást kifejteni, de csak abban az esetben, ha meg tudunk küzdeni a nehézségekkel, amihez azonban erényekre van szükség.

Ebben rejlik a liberális eszmerendszer új korszakának ugrópontja. A dolgozat arra tesz kísérletet, hogy ebben az új korszakban, egy korábbi eszmetörténeti korszak elemzésén keresztül mutassa meg: létezik a liberális eszmerendszeren belül olyan gazdaságstratégiai tervezési és társadalomszervezési irányzat, amely képes válaszokat adni a jelenkor kihívásaira.

\subsection{Az eszmerendszerek meghaladásának felvetése}

A világ és Európa jövője a hagyományos politikai törésvonalakon kívül dől majd el, azonban ez nem jelenti azt, hogy a három eszmerendszernek ne volna feladata kezelni saját krízisét, és az új kihívásokra releváns válaszokat adni. Az eszmerendszerek igazodási pontok, amelyek akkor is fontosak, ha nem születik belölük párt- vagy választási program. Az államhoz, az egyénhez és a közösséghez való viszony alapvetően kiolvasható az eszmerendszerekböl. A megújulási kötelezettség abban áll, hogy az aktuális kihívásokra adott válaszokat ezekből az alapkövekből származtassák, és jövőképet vázoljanak fel a társadalmak számára. 


\subsection{Mire használhatók a liberalizmus előző eszmetörténeti szakaszában elkövetett hibák?}

„A liberalizmuson kivül egyik politikafilozófiai irányzat sem bizonyitotta még be a gyakorlatban, hogy képes nagyobb jólétet biztositani, viszonylagos politikai stabilitást teremteni, valamint szabályszerüségének és kiszámithatóságának köszönhetöen elömozdítani az egyéni szabadságot.” (Deneen, 2019. p. 39.) Mára azonban számos elért eredmény területén mutatkoznak kudarcok úgy az államépítésben, mint a piacon, vagy a demokratikus intézményrendszerben. A XXI. század eleji új kihívások különösen próbára tették az eszmerendszert, ráadásul legutóbbi eszmetörténeti fejezetének gazdaságstratégiai ajánlata teljesen szembement az eredetileg általa megalkotott emberkép által megkövetelt államszervezési feladatokkal.

Noha az egyén szabadságának gondolata több ezer évvel ezelött került a filozófiai gondolkodás látóterébe, a legtöbbször mégis arra figyelünk, hogy a középkor végén és a kora újkorban megjelenő filozófusok által megalkotott klasszikus liberalizmus mit hozott a társadalomszervezésbe. Ennek valószínüleg az az oka, hogy az ókori görög és római gondolkodók sokkal inkább müvészetként tekintettek a filozófiai gondolkodásra, mint tudományként (Deneen, 2019.), az első „tudományos liberálisok” azonban, a klasszikus politikai gazdaságtan alapjainak lefektetése mellett, éppúgy foglalkoztak morális és erkölcsi kérdéssel, ahogyan Platón vagy Arisztotelész. A liberalizmus válságában az egyik fő mozzanat, hogy az eszmerendszer elmélete és gyakorlata ma már alig hasonlít 400 évvel ezelőtt fejlődésnek indult előképére.

„A görög filozófia kiemelte, hogy a paideának, azaz az erényben való nevelésnek elsödleges funkciója van a zsarnokság megelözésében és az állampolgárok szabadságának megvédésében.” (Deneen, 2019. p. 40.) Az európai történelemben különböző kultúrák megfogalmazták ugyanezt, a középkori keresztény filozófiai hagyomány is kitartott amellett, hogy az erényre való nevelés fontos szerepet játszik a zsarnokság visszaszorításában és a szabadságért való küzdelemben. Ezt a XXI. században már úgy mondjuk: a polgárok önuralma és erényes viselkedése teszi őket képessé arra, hogy a szabadságukkal élhessenek.

Van olyan elképzelés, amely szerint a politikát az alantasra kell építeni, de ez egyetlen valódi fejlődést hozó teoretikusnál sem merült fel értékképző gondolatként. Az ókori filozófia, valamint a középkori keresztény filozófia is az önkorlátozásból vezette le az egyén fejlődését, megerősítve ezzel a családban és egyéb közösségekben müködő normákat. Ez egyúttal azt is jelenti, hogy a korai szabadelvü gondolkodók szerint az 
egyént kell képessé tenni arra, hogy korlátozza önmagát, valamint arra, hogy különbséget tudjon tenni jó és rossz között. Descartes és Hobbes is amellett érveltek, hogy a kritikátlanul elfogadott vallási tanításra épülő uralom „önkényes kormányzást, valamint meddö és pusztító konfliktusokat eredményez, emiatt pedig megakadályozza, hogy szilárd és virágzó rendszer jöhessen létre”. (Deneen, 2019. p. 44.) A kulcs ezek szerint nem a felülről érkező és kétely nélkül végrehajtott parancsokban vagy erőltetett tanításokban keresendő, hanem az önkorlátozó, normakövető egyénben.

Patrick J. Deneen amellett érvel, hogy a liberalizmust a filozófiai hagyományok lerombolása, valamint az térítette el a helyes útról, hogy az individuális jogokat előbbre valónak tartotta a hagyományoknál. A felvilágosodáskori gondolkodókat úgy említi, mint akik a tudatlanság korának végét hozták el, ám azáltal, hogy a régi hagyományokat, hiedelmeket lerombolták, valamint újraértelmezték az ember és a természet viszonyát, öntudatlanul csapdát állítottak az emberiségnek. A szerző állítása az, hogy a liberalizmus társadalomszervezési ajánlata állami szinten polarizálja a társadalom tagjait, mivel intézményesíti az önérdekkövetést.

Ezzel szemben jelen dolgozat amellett érvel, hogy az erényre való nevelés nem pusztán az ókori filozófiában, de a felvilágosodás korában is jelen volt a liberális politikafilozófusok körében, a XX. század közepén pedig az ordoliberalizmus élesztette újra ezeket a gondolatokat.

A jelenkor liberális gondolkodóinak kihívása, hogy a tolerancia-eszmét társadalmi csoport kérdőjelezi meg a szabad világban, mert hiányzik az az erkölcsi alap, amit mindenki magáénak tud. Kell beszélnünk a négy alaperényröl, mert igazodási pontot nyújtanak, amely a tolerancia-eszmén túlmutat. A négy alaperény ${ }^{4}$ mutat rá arra, hogyan tegyünk különbséget jó és rossz közt, és hogyan álljunk ellen a kettő közti határok elmosásának. A bátorság, a bölcsesség és a mértékletesség az igazságosság védőernyője alatt tudják kifejteni társadalmi hatásukat.

Immanuel Kant szerint az erkölcsösség elérhető, ha minden embert felruházunk a szabadsággal. Adam Smith természetesnek veszi a másik ember iránti együttérzés képességét. Úgy látja: megvan bennünk a képesség, hogy belehelyezkedjünk a másik ember helyzetébe, és bár a mi érzelmünk nem lesz olyan erős, mint a másik ember eredeti érzelme, mégis - ahogyan Smith fogalmaz - „ez a két érzés, evidensen

${ }^{4}$ http://keesz.hu/idokjelei/pdf/ujra neven nevezzuk.pdf 
összecseng annyira egymással, ami elegendő a társadalom harmóniájához" (Smith 1982. p. 22.).

Russ úgy ír Smith-ről: „időtálló tanácsokat ad arra vonatkozóan, miként bánjunk a pénzzel, a vágyainkkal, a hírnév és az erkölcs kérdéseivel. Elmondja az olvasónak, hogyan lelhet a boldogságra, hogyan kezelje az anyagi sikereket és bukásokat, felvázolja, miként lehetünk erényesek, jók, és miért éri meg számunkra, hogy azok legyünk.” (Russ, 2014. p. 4.) Az erkölcs és a morál vizsgálatának évezredes története a XX. században is folytatódott. A közgazdaságtudomány képviselői közt éppúgy megtaláljuk öket, mint a filozófusok közt. Röpke (J. Horváth, 2000.) az emberséges gazdaság kialakítását erkölcsből levezethető parancsnak nevezi a múlt század ötvenes éveiben.

Deneen azt állítja, a jelenkor társadalmi kihívásai a liberalizmus kudarcát tükrözik. De az önérdekkövetés, valamint a hagyományos közösségekben meglevő szolidaritás meggyengülését nem a liberalizmus hozta el. A polarizált társadalom nem a szabadság eszméjének válsága, hanem a kapitalizmus kudarca.

A kérdés felvetése jogos, hogy a fejlődést vajon túléli-e az emberiség, azonban a liberalizmust felelőssé tenni azért, mert a neoliberalizmus korszakában összekeverték a piaci növekedést a technológiai fejlődéssel, éppúgy hibás következtetés, mint azt állítani, hogy a neoliberalizmus hegemóniájának jótékony elmúlása a liberalizmus halálát is elhozná.

Deneen John Locke-ot Thomas Hobbes filozófiai örökösének tekinti, miközben figyelmen kívül hagyja azt a tényt, hogy John Locke - bár Hobbesra épít - mégis inkább kritikusa, mintsem mesterének elméleti továbbvivője. Hobbes (1651) úgy fogalmaz: „a kegyetlenség, állatias egoizmus, a korlátlan szenvedély igazgatja, döntéseit a félelem és a bizonytalanság irányítja". Vele szemben John Locke hasonlóan Smithhez - az erkölcsösség mellett érvel, azt állítja: az ember alapvető jellemzője az erkölcs. Bár Locke az iskolát nevezte meg elsődleges intézményként, ahol az egyének fejlődhetnek, azt állítja, hogy a bölcsesség ruházza fel az embert a képességgel, hogy különbséget tegyen jó és rossz között. "Azt hiszem, te magad is nagy balgának tartanád azt, aki az erényes és bölcs embert nem becsüli százszorta többre a tanult embernél”. (Locke, 1914. p. 161.) Ezzel egyébként amellett is érvel, hogy hiába a világról szerzett ismeretek sokasága, ha az erényesség nincs egy ember birtokában. Míg Thomas Hobbes azt állítja, hogy a törvényeknek úgy kell müködniük, akár a sövény, hogy az útról lesodródókat megfogja, addig John Locke úgy véli, lehet úgy 
nevelni az egyént - szigorúsággal -, hogy ö végül a lehető legkevesebb valószínüséggel térjen le a morálisan helyes útról. Emberképe a gentleman, az erkölcsös, müvelt, fegyelmezett ember. (Locke, 1914.) Természetesen az erénnyel és erkölccsel foglalkozó felvilágosodáskori gondolkodók köre nem ér véget itt. David Hume nem pusztán az erénnyel, a barátsággal is foglalkozik. Azt írja: „Elismerem, hogy a dolgok jelenlegi rendjében az erénnyel nagyobb lelki nyugalom jár együtt, mint a bünnel, s a világ részéröl az erény kedvezöbb fogadtatásban részesül. $S$ azzal is tisztában vagyok, hogy az emberiség múltbeli tapasztalatai szerint a barátság az emberi élet legnagyobb öröme, s a mértékletesség a nyugalom és boldogság egyedüli forrása. Az erényes és vétkes életmód közt sosem ingadozom, mert tudván tudom, hogy a jó szándékú emberek számára minden elöny az elöbbi oldalán van.” (Hume, 1748) A klasszikus liberalizmusnak - szemben Deneen állításával - nagyon is része volt a morálfilozófia, így az eszmerendszer nem a születésekor romlott el, és nem is nélkülözi saját javíthatóságának képességét. A gyökereitől való elszakadás, az erkölcs nélkülözése az, ami végül elvezetett odáig, hogy utat tévesztett, és a végén már nem avatkozott közbe, amikor klasszikus elveivel teljesen ellenkező erőket mozgósított a piac és a társadalom szervezésére. Jelen dolgozat azért született, hogy amellett érveljen: a liberalizmus - bár számos hibát elkövetett - nem végső kudarca utáni haláltusáját, hanem minden eddiginél nagyobb válságát éli, amelyben szükséges a részletes önértékelés, valamint annak elemzése, hogy mely eszmetörténeti korszakok szakadtak el a liberalizmus legbelső értékeitől úgy, hogy azok magát az eszmerendszer létét is veszélybe sodorták - azokkal a vívmányokkal együtt, amelyeket az emberiség neki köszönhet.

A neoliberalizmus klasszikus liberalizmustól való elkülönítése és a korszak hibáinak korrekciója éppen ezért kulcskérdés a liberális eszmerendszer vizsgálata szempontjából. Fontos tárgyalni, hogy a klasszikus liberalizmus elvei hogyan használhatók a politikai, társadalmi és gazdasági válságból való kilábaláshoz. A tolerancia, az elfogadás, a béke, a szabadság és a felelősségvállalás az eszmerendszer alapértékein és alapelvein nyugszanak, ezek voltak azok az értékek, amelyek mentén megszövegezték az ENSZ Alapokmányt és a Római Szerződést. Ezek az értékek nem veszélyesek. Egy olyan világ azonban veszélyes, mely ezeket az értékeket nélkülözi -

${ }^{5}$ https://www.scribd.com/document/237239070/Hume-Tanulmany-Az-Emberi-Ertelemr\%C5\%911 
erről szólt a második világháború, de erről szólnak a közel-keleti konfliktusok, melyek gyakorta embertelen fegyveres ütközetté fajulnak. ${ }^{6}$

A világban általánosan csökkenő szabadság és a csorbuló jogállami normák mellett kérdés, hogy az egyes társadalmak meg tudnak-e küzdeni azért, hogy a nyugati szövetségi rendszer európai felén helyreálljon a II. világháborút követő európai jogállami és társadalomfejlődési irány: a liberális demokrácia intézményei ne sérüljenek. A szabadság és a szolidaritás összekapcsolása, melyen az Európai Unió létrejötte óta dolgozik, mára a biztonság és szabadság kettősével bővült (Fehér könyv Európa jövőjéröl, 2017.)

Az egyéni felelősségvállalást követően egy következő fejlődési lépcsőfok: a közösségi felelősségvállalás lépcsőfoka (Dardot-Laval, 2013), a szolidaritás feltételezi a közösségi felelösségvállalást. Ez a racionalitás azon szintje, amiben megértésre lel a tétel: amennyiben a társadalom jelentős hányada nélkülöz, a társadalom felemelkedése nem lehetséges. (Smith, 1776.) E tétel a klasszikus liberalizmus időszakában még elfogadott volt, a későbbi történelmi korszakok teremtették a képet, mely szerint a liberalizmus nem képes a társadalmi szolidaritásra.

A XX. század felkavaró világpolitikai és társadalmi folyamatai után, a bipoláris világ összeomlását követően a nemzetállamok és regionális szinten integrált nemzetközi közösségek keresték a lehetőséget egy új társadalmi-gazdasági modell kialakítására. Ez a modell geopolitikai szinten időlegesen nagyobb stabilitást biztosított ugyan, de belső, szerkezeti instabilitása miatt felbomlóban van. E szerkezeti instabilitás lényege, hogy a hosszú távú politikai célokat nem tudta világosan kifejezni, és ezért gazdasági kényszerként állította be azokat.

Olyan társadalmi kommunikációt folytatott, s olyan elméleti keretet támogatott, amelyben a piac - beleértve a világpiacot - müködése szavatolja a jólétet és a biztonságot.

A magára hagyott, önszabályozó piac jólét- és biztonságszavatoló mivoltát hangsúlyozni nyilvánvalóan hamis kép, amelynek kritikáját a közgazdaságtan történetében többször is megfogalmazták, azonban egyrészt ez nem azt jelenti, hogy az elmúlt ötven év gyakorlata összhangban lett volna a hirdetett piacmodellel: a kritikáknak össze kell tudniuk egyeztetni a gazdálkodói szabadság eszméjét a létbiztonsággal. Erre egy jól szervezett piac alkalmas lehet.

\footnotetext{
${ }^{6}$ https://www.sipri.org/yearbook/2017/03
} 
Mivel a politikai fóáram válaszképtelennek mutatkozik több olyan kihívást illetően, amelyek hatékony választ és cselekvést kívánnak, helyüket több esetben a szélsőségek, a radikális megoldásokban gondolkodó politikai irányzatok vették át, amelyek sok esetben csorbítják a demokratikus intézményrendszert, a jogállami normákat, valamint az egyéni és csoportos szabadságjogokat.

A XXI. század kihívásai sokrétüek. Adott a gazdasági kihívás, amely a fejlődő világ túlnépesedése, a fejlett világ idősödő társadalma és a kihasznált természeti eröforrások, fosszilis energiahordozók várható kimerülése miatt halaszthatatlan válaszokat kíván, az éhínség, a járványok vagy egy egész világra kiterjedő háború megakadályozásának érdekében. (Simai, 2016.)

A világ népességéhez mérten az euroatlanti térség jelentősen hozzájárul a világ GDPjéhez, azonban látványosan elkezdett veszíteni pozíciójából.

\begin{tabular}{|c|c|c|c|}
\hline \multicolumn{4}{|c|}{ Európa részaránya a világ GDP-jében zsugorodik } \\
\hline & 2004 & 2015 & \\
\hline Amerikai Egyesültt Államok & $28 \%$ & $24 \%$ & $\mathbf{y}$ \\
\hline EU27 & $26 \%$ & $22 \%$ & $\mathbf{y}$ \\
\hline Japán & $11 \%$ & $6 \%$ & $\mathbf{y}$ \\
\hline Egyesült Királyság & $5 \%$ & $4 \%$ & y \\
\hline Kína & $5 \%$ & $15 \%$ & $\lambda$ \\
\hline Kanada & $2 \%$ & $2 \%$ & $\Rightarrow$ \\
\hline Mexikó & $2 \%$ & $2 \%$ & $\Rightarrow$ \\
\hline Brazília & $<2 \%$ & $2 \%$ & ב \\
\hline India & $<2 \%$ & $3 \%$ & त्र \\
\hline A világ többi része & $18 \%$ & $21 \%$ & 2 \\
\hline
\end{tabular}

A népességarányához mérten világszintű össztermékhez jelentősen hozzájáruló európai térség élen jár abban a törekvésben, hogy csökkentse a szociális egyenlőtlenségeket vagy növelje a társadalmi igazságosságot. (Fehér könyv Európa jövőjéről, 2017.) 


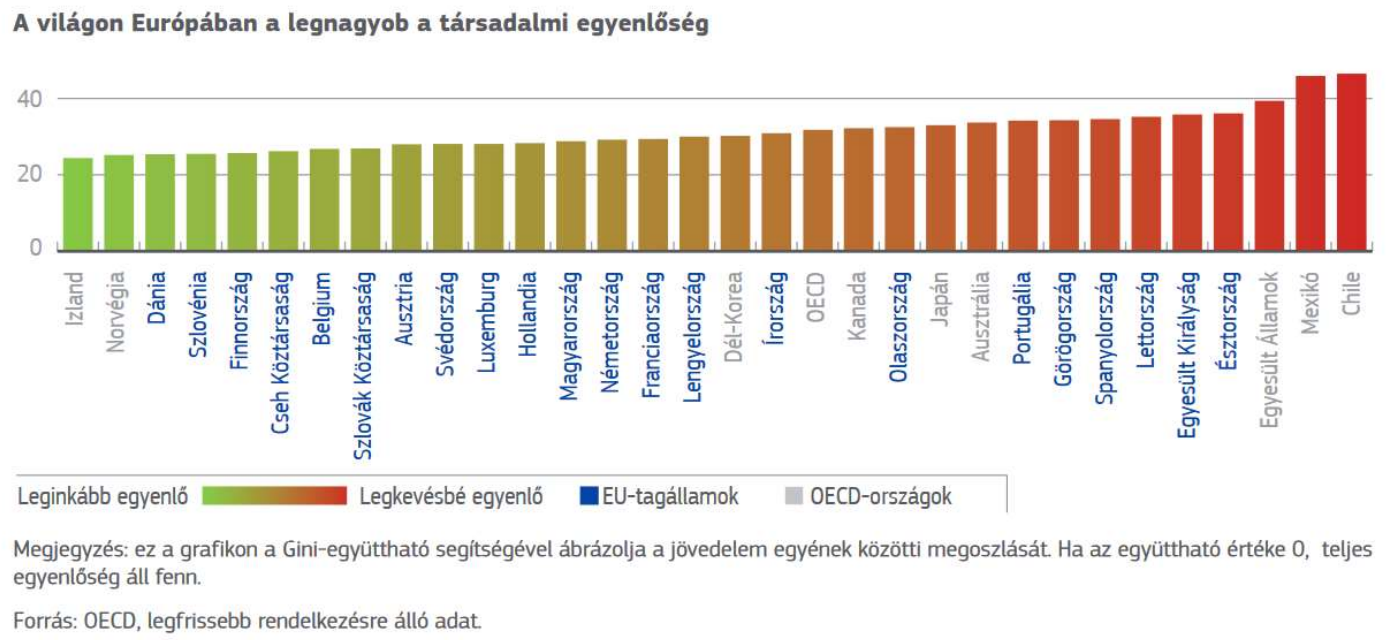

A centrum és a periféria minden eddiginél közelebb állnak egymáshoz az információáramlást és a kihívások globális terjedési sebességét tekintve.

Az elmaradottság felszámolása, valamint a társadalmi mobilitás hiánya globális szintre helyeződött. Ezzel párhuzamosan globalizálódott a lázadás lehetősége: a terrorizmus technológiai eszközei, hatóköre, valamint egy terrorszervezet szervezhetőségének lehetőségei minden korábbinál látott mértéknél könnyebben bővültek, az élhetetlenné vált régiókból való elvándorlás sosem volt ilyen könnyen kivitelezhető. Ezek miatt a globális kihívások előbb váltak határok nélküli utazóvá, mint a rájuk teremtett megoldások - már ha léteznek egyáltalán. A megoldandó feladatok keletkezésének tempója messze meghaladja a rájuk adott megoldások keletkezésnek tempóját, ez pedig társadalmi feszültségeket okoz. Emiatt megkérdőjelezik a korábbi társadalmi berendezkedést, sőt, viták keletkeztek az eleddig elfogadottnak tekintett emberi együttélési formákról, rendfenntartásról, nemzetbiztonságról, politikai rendszerekről, demokratikus intézményrendszerről, az emberek jogairól és kötelességeiről. (Simai 2016.)

Az emberiség és a Föld jelenleg sok tekintetben türéshatárait feszegeti, és elkerülhetetlen, hogy a hatalmi struktúrában átrendeződés történjen. A XX. század tapasztalatai azt mutatják, hogy fenntartható rendszer abban az esetben keletkezik, ha a társadalomszervező a jólétet, jogegyenlőséget, egyenlő méltóságot, biztonságot, szabadságot, demokráciát kívánja szolgálni. A válságok megjelenésekor általános, hogy alapvetően antidemokratikus populisták győzedelmeskednek a választásokon, és demokratikus keretek között veszik át a hatalmat, majd fokozatosan megvonják a társadalom tagjainak jogait, egyéni és kollektív szinten is. 
Az emberiség válaszokat keres a felmerülö kérdésekre, ugyanakkor a kérdések sem vetődtek fel világosan, hiszen elhomályosítják őket a társadalmi feszültségek, melyek a közösségek tagjainak széles körében tapasztalhatók. A világszintű társadalmi egyenlőtlenségek növekedése, a globális kihívásokra adott válaszok hiánya, az elodázott intézkedések, a sokszor határozatlan és káoszt teremtő intézkedések mind azt üzenik, hogy az egyes nemzetállamok, de akár a nemzetközi közösségek is rossz kézben vannak. (Simai, 2016.)

A neoliberalizmus és a neokonzervativizmus szegényekkel és elesettekkel szemben követett álláspontja, a velük való szolidaritás megtagadása a '70-es, '80-as években széles tömegek számára vált népszerüvé, hiszen szembefordult a jóléti állam túlzott, időnként indokolatlan egyenlőségközpontúságával, azonban egy ponton ez már veszélyeztette az állam stabilitását. Ezt a folyamatot némileg enyhítette ugyan a szociáldemokrata harmadik út, amely lényegében a liberalizmus alkalmazása volt a szociáldemokráciára. A harmadik út úgy foglalható össze, hogy liberális gazdaságpolitikai és társadalompolitikai keretrendszer, ötvözve azzal a gondolattal, hogy az államnak felelősséget kell vállalnia az elesettekért. Összességében azonban az eszmerendszer mind a két szakaszát azonos elméleti keret határozta meg, a piaci szabadság támogatása és az állami eszközök leépítése.

A neokonzervativizmus és a neoliberalizmus némileg másként müködött Nyugaton, mint a mi térségünkben. A Kelet-Közép-Európában lezajlott rendszerváltásnak köszönhetően ebben a régióban kifejezetten ez az ideológia volt a modernitás, a társadalom következő lépcsőfokának elhozója - a „szabadság hírnöke”. Ugyanakkor az eszmerendszer megállíthatatlanul haladt az újabb válság felé, amelybe az elmúlt fél évtized során Európa-szerte buktak el liberális pártok, marginalizálódtak vagy tűntek el teljesen. Ezek a közéleti formációk álláspontom szerint azonban csak jelzik az eszmerendszer válságát, és nem okai annak. Amíg az eszmerendszernek nincs egységes válasza arra, hogy a klasszikus liberális elveknek megfelelően válaszokat találjon a XXI. századi kihívásokra, addig gyakorlati képviselői nem tudják azt 0alkalmazni saját társadalmukra.

A neoliberalizmus, amely a konkrét politikai gyakorlatban tagadta, hogy ő maga ideológia volna, és úgy vélekedett önmagáról, hogy ő a megtestesült észszerűség, mégiscsak ésszerütlen világot teremtett. Olyan gépezetet épített ki a világpiacon, amely amellett, hogy nem volt képes sem elöre jelezni, sem megakadályozni, sem 
kezelni a 2008 III. negyedévében kezdődő világgazdasági válságot, emellett nem sarkallt felelősségvállalásra.

A neoliberalizmussal együtt épülő neokonzervativizmus kimondta: a jólétben élő, saját életét megoldani képes ember erkölcsi fölényben van azzal az emberrel szemben, aki munkanélküli, nincstelen, vagy szélsőséges esetben nincs fedél a feje fölött. Ez az üzenet bizonyos társadalmi csoportokat ugyan felemelt, másokat azonban megöröklött szegénységben tartott, ami össztársadalmi értelemben, a szakadékok elmélyülését követően, nem szolgálta a fejlődést.

A XX. század második felében egyéni felelősségvállalást és gazdasági fellendülést hozó eszmetörténeti szakasz a rendszerváltás előkészítésében és lefolytatásában is nagy szerepet játszott, azonban társadalmi szakadékokat és szolidaritáshiányos környezetet teremtett. A neoliberalizmus válaszképtelennek mutatkozott mind nemzetgazdasági, mind világgazdasági szintű kihívásokra, melyek a XXI. században keletkeztek, mint a „szegénység ördögi köre” (Nurkse, 1953.), az esélyegyenlőség hiánya, vagy akár a menekültválság. Ennek a válaszképtelenségnek egyenes következménye, hogy a neoliberalizmus korszaka lezárul.

A legújabb kori társadalomszervezők felismerték, hogy a szabadság egyenlőtlen eloszlása nem jellemezheti a társadalmat, valamint azt, hogy a köztársasági hagyomány kevesebb, mint a jogállami hagyomány. A munkapiac szervezése fontos, a XXI. században pedig az lett irányadó, hogy szervezése az emberi méltóságot szolgálja. A XXI. századi liberalizmus ilyenformán nem azt jelenti, hogy a társadalomszervező a lehető legnagyobb piaci szabadságot biztosítja a társadalom tagjainak, hanem azt, hogy a legnagyobb intézményrendszerek az egyenlő méltóság és az egyenlő bánásmód elvét szolgálják - akár feláldozva érte a kisebb állam melletti érvet. (Kis, 2009.)

A dolgozat állítása, hogy az új évezred társadalmi és gazdasági változásai közepette a liberalizmusnak abban az esetben van esélye a megújulásra, ha új fejezete a felelősségvállalást és a közösségi gondolkodást helyezi a középpontba. (Dardot-Laval, 2013.)

A dolgozatban a liberalizmus következő fejlődési lépcsőjének megnevezésére az „újliberalizmus” fogalmát használom. Az újliberalizmus a dolgozat felfogása szerint az ordoliberális hagyományokhoz való visszatérést jelenti. Az ordoliberálisok jártak a XX. században a legközelebb ahhoz, hogy a klasszikus liberális elvek a gyakorlatban is megvalósulhassanak. 
A benthami és locke-i hagyományokhoz való visszatérés szintúgy fontos a dolgozatban. John Locke szerint a nevelés az a folyamat, amely során az ember válik valamilyenné. Ahhoz, hogy felelősségvállalásra képes, felnőtt állampolgárok tudjanak felnőni, jól müködő oktatási rendszer kell, ahol a közösségi gondolkodás áll a középpontban. A dolgozatban a közösségi gondolkodást, az egymásért és a társadalomért való felelősségvállalást, Dardot és Laval (2013.) nyomán nevezem , ,ujj racionalitásnak’.

Az új liberalizmus az erös versenyfogalom definíciója mellett teszi le a voksát, és a szabadság, valamint az egyéni felelösségvállalás kettőse lesz számára a legfontosabb. Ugyanakkor az újliberalizmus már nem épít egyoldalúan a „homo oeconomicus”-ra (Csuka et. al., 2008.) Ha a liberalizmus emberképe így alakulna át, az eszmerendszer meg tudna fogalmazni egy olyan gazdaságstratégiai tervet, amely alapján az új gazdasági rend is emberközpontúvá válhat. Ezzel a neoliberalizmus által elkövetett hibákat kiküszöbölné.

A neoliberalizmus időszakában kiépült „,kockázat társadalma” (Dardot-Laval, 2013.) szabadpiaci keretek között, liberális alapértékeken nyugvó gazdaságpolitikával, Dardot és Laval szerint az alábbi erényeket kívánja meg a gazdaság szereplőitől:

- bátorság

- kockázatvállalás

- felelősségvállalás

- szabálykövetés

- önmegvalósítás.

$\mathrm{Az}$ egyén szempontjából mindig az a kérdés, hogy mit kezd egy adott feltételrendszerrel. Az újliberalizmus általam vélelmezett ideális modelljében - a francia szerzőpáros megfogalmazása alapján - ,fegyelmezett önmegvalósitók” alkotják a társadalom kritikus tömegét, akik nem vitatják el a másik ember szabadságát, betartják a szabályokat, és készek kockázatot vállalni. Az új liberalizmus gazdaságpolitikájának kérdése pedig az, hogy hogyan kell szabályozni a piacot, hogy az valóban segítse az egyént abban, hogy ezeket az erényeket vagy tulajdonságokat meg tudja tanulni, és nap mint nap erősödjön benne az a képesség, hogy megállja a helyét a szabad piacon.

Foglalkozom az amerikai és a német szabályozási logika különbségével. Az amerikai logika szerint „mindent szabad, ami nem tilos” elvével, a német liberalizmus szerint, azt szabad, ami szabályszerüen engedélyezett. A dolgozatban a kettő összhangját is 
kutatom, mert előfeltevésem a szabálykövető egyén. Úgy vélem, hogy ilyen emberképpel, megfelelő gazdaságstratégiai és társadalomszervezési ajánlattal, a jövő globális kormányzásában a jelen kor társadalmai képesek lesznek maguk mögött hagyni olyan hibákat, amelyek a korábbi válságokat okozták. (Dardot-Laval, 2013.) $\mathrm{Az}$ ordoliberalizmushoz való visszatérést a dolgozat azért tartja megfelelő megoldásnak, mert a II. világháborút követő időszakban morális, gazdasági és társadalmi válságból kellett felállni, és ezt az ordoliberális gazdaságstratégiai tervezés, valamint társadalomszervezési ajánlat képes volt segíteni. Amellett érvelek, hogy a rendszerváltás egy fegyverek nélküli háborúként is felfogható, és a transzformációs válság sok tekintetben hasonló társadalmi kihívásokat teremtett, mint a háború utáni korszak.

A liberalizmus dolgozatban elemzett fejlődési lépcsőfokai, elkövetett hibáiból való tanulságok, valamint az egyes társadalmakban megteremtett fejlődési potenciál azt mutatják, hogy az eszmerendszer azokban a korszakokban tudott a leginkább hozzájárulni a társadalom és a gazdaság fejlődéséhez, amikor az erkölcsöt helyezte középpontba. Ez az értékválasztás a klasszikus liberális elvekkel is összhangban van, de a szabadság, a rend és a szolidaritás közti összhang keresése közepette is sikeres modelleket teremtett.

\subsection{A dolgozat hipotézisei}

1) A neoliberalizmus korszaka lezárult, egy új eszmetörténeti korszak veszi kezdetét a liberális eszmerendszer keretein belül.

2) A liberális eszmerendszer keretein belül létezik olyan gazdaságstratégiai tervezési irány, amely releváns válaszokat ad a jelenkor kihívásaira.

\subsection{A dolgozat állítása:}

A piaci eszköztár - megfelelő társadalomszervezés esetén - szolgálhatja az egyenlő méltóság és egyenlő bánásmód elveit, a piac ebben a felfogásban nem cél, hanem eszköz a nagyobb jólét és a nagyobb jogegyenlőség felé vezető úton. 


\subsection{A dolgozat módszertana és a szakirodalmi háttér bemutatása}

A dolgozatban alapvető módszertanként az összehasonlító forráselemzés jelenik meg, amely kiegészül a liberalizmus történeti és eszmetörténeti bemutatásával, valamint makrogazdasági adatok elemzésével.

A dolgozat eszmetörténeti és történeti fejezetei az ókori filozófia, a felvilágosodáskori filozófusok, a morálfilozófia, a klasszikus politikai gazdaságtan alapjait képező gondolkodók mủvein, valamint a XIX. és XX. századi liberalizmus képviselőinek forráselemzésén alapulnak. Az ókori filozófiából származó alaperények mellett a liberális eszmerendszer közel négy évszázados történetének erkölcsöt és erényt elemző, ezeket előtérbe helyező gondolatain vezetnek végig ezek a fejezetek.

A dolgozat elemez statisztikák és nemzetgazdasági mutatók alapján egy közel négy évtizedes makrogazdasági trendvonalat a Német Szövetségi Köztársaság II. világháborút követő szűk négy évtizedéből. A neoliberalizmus és az ordoliberalizmus eszmetörténeti korszakainak bemutatására az összehasonlító elemzés módszerét választottam, a gazdaságstratégiai tervezési és társadalomszervezési ajánlatból következő társadalmi-gazdasági következmények, valamint mikro- és makroökonómiai eredmények tekintetében.

Az utolsó fejezet kitér egy gyakorlati példára, az Európai Unióra a liberális eszmerendszer és liberális demokrácia megerősítése szempontjából vizsgálja a Fehér Könyv Európa Jövőjéről című kiadmányt, összehasonlító elemzést ad a lehetséges forgatókönyvek alapeseteiről, valamint kitér az Unió következő költségvetési ciklusára előirányzott alapelvekre, amelyek a demokráciát és a jogállamot védelmezik a közösségben. Az EU nem esettanulmány ugyan, de jó példa arra, hogy mi történik egy közösségben, amelynek nem csak elméletben, de gyakorlatban is fontos a liberális eszmerendszer értékeiből következő intézményrendszer és a társadalomszervezési alapelvek. Ezek kikényszeríthetőségét a dolgozat nem elemzi, a Fehér Könyv és a jelenleg zajló költségvetési ciklus (2020-2027) elméletben megjelenő célrendszerét azonban sorra veszi.

A hipotézisvizsgálat a fenti forráselemzéseket, valamint nemzetgazdasági eredményeket használja bizonyításul, a gazdaságstratégiai és társdalomszervezési, valamint államszervezési ajánlatok hiányosságait pedig egy empirikus kutatáson alapuló tanulmánnyal pótolja, amely az erényekről, az erkölcsről és ezek taníthatóságáról szól. 
Jelen írás Arisztotelésztől Platónon át John Locke, Hugo Grotius, Immanuel Kant, Adam Smith, David Hume, Thomas R. Malthus, John Stuart Mill, David Ricardo, Thomas Jefferson, Edmund Burke, Ludwig Erhard és Wilhelm Röpke gondolatait kölcsönzi annak bizonyítására, hogy a liberalizmus azon eszmetörténeti korszakaiban segítette leginkább a társadalomfejlődést, amikor a morális kérdéseket elsődlegesnek tekintette. A neoliberalizmus mintegy négy évtizedes történetének, gazdaságitársadalmi eredményeinek elemzésén keresztül pedig bemutatja az ellenpróbát: egy olyan időszakot, amelyben mintha annak társadalmi kísérlete zajlott volna, hogy mi történik abban az esetben, amikor a gazdasági liberalizmus - ahelyett, hogy kiegészítené azt - felülkerekedik a politikai liberalizmuson és az erények uralmán, ezzel szembefordulva a klasszikus liberalizmus eredeti céljaival.

A forráselemzéseken túl a dolgozatban a jelenkori kihívásokra adható lehetséges válaszok klasszikus liberális elvekből való levezetése áll a középpontban. Ez abból a szempontból fontos, hogy a dolgozat egyik alapállítását támasztja alá, miszerint a XXI. században nem eszmerendszerek nélküli világ következik, hanem az a kérdés, hogy az eszmerendszerek képesek-e megújulni oly módon, hogy szolgálják a társadalomfejlődést. A dolgozat tehát nem pusztán eszmetörténeti feldolgozás, de értékeli is az elméleti viták gyakorlati példáját.

Végül pedig, annak bizonyítása után, hogy az államszervezésnek nem pusztán jogi, de bölcseleti törvényei is vannak (Gervai-Trautmann, 2013.), a dolgozat egy tanulmány (Vezzali et al, 2015.) bemutatásával azt kívánja bizonyítani, hogy a megfelelő államigazgatási és intézményrendszeri keretek megadása mellett fontos a társadalom tagjainak megfelelő oktatása is. Ezen keresztül elérhető, hogy ne egy csupa „ördögökböl álló nép” (Kant, 2015.) legyen az, amelynek társadalomszervezési ajánlata az erényeken és az egyenlő méltóság elvének mind nagyobb érvényesítésén nyugszik.

\subsubsection{Várható eredmények}

A dolgozat előfeltevéssel él, hogy a liberalizmus hozzájárulhat a XXI. századi kihívások kezeléséhez, és képes megújulni, olyan társadalomszervezési ajánlatot megfogalmazni, amely segíti az emberiséget abban, hogy ne pusztán környezeti, de társadalmi értelemben is beszélhessünk fenntarthatóságról. 


\section{A KLASSZIKUS LIBERALIZMUS GAZDASÁGSTRATÉGIAI ÉS TÁRSADALOMSZERVEZÉSI AJÁNLATA}

A felvilágosodás filozófusai, természettudósai, jogászai és közgazdászai a szabadság és a rend összhangját keresték. A liberalizmus eszmerendszerének megteremtői olyan korlátok mellett érveltek, amelyeket az egyéni és kollektív szabadságjogok érvényre jutása érdekében emeltek. Az állami intézményrendszer azon formáját tartották kívánatosnak, amely garantálja az alkotmányos önkorlátozást, a hatalmi ágak szétválasztását, a jog uralmát, a gazdaságra nézve pedig megvalósítja az állam „éjjeliőr” funkcióját.

A lassez faire liberalizmus időszakát a morálfillozófusok nem a szolidaritáshiányos társadalommal azonosították, épp ellenkezőleg. A monopóliumok káros gazdasági és társadalmi hatása ellen küzdve, a munkavállalók jogaiért és a kisvállalkozások szabadságáért kiálló gondolkodók úgy vélték, nem pusztán jogi, politikai, de gazdasági értelemben is egy igazságosabb és élhetőbb világot teremthetnek a liberális eszmerendszer alapelvein keresztül, melynek része a szabad, ám a tisztességtelen piaci magatartást kiszürő piacgazdaság. (Smith, 1776.) Bár a liberalizmus további korszakai közül voltak olyanok, amelyek elmozdultak a piaci fundamentalizmus irányába, ez az eszmerendszer hajnalára nem volt jellemző.

A XVI. és XVII. század liberális gondolkodói úgy vélték, mindenkit megillet a tisztességes bérezés, a társadalmi mobilitáshoz való jog és az a lehetőség, hogy ki-ki munkáján keresztül megküzdhessen saját nyomorának felszámolásáért, és önmaga felemelkedéséért. Az egyéni fölemelkedések összessége közösségi szinten gazdasági növekedést hoz, nagyobb jólétet, így végső soron az állam úgy látja el azon kötelességét, hogy a társadalom gazdagodását, valamint a polgárok jogegyenlőségének megvalósulását szolgálja, hogy - önmagát is korlátozva - hagyja, hogy mindenki megtalálhassa a helyét a piacon - akár vállalkozóként, akár munkavállalóként - úgy, hogy közben más gazdasági szereplők sem korlátozzák őket ebben a tisztességes versenyben. E rendszer keretein belül kizárólag a teljesítmény lehet az, ami különbséget tesz ember és ember vagy vállalat és vállalat között.

„A liberalizmus politikai értékek és elvek együttese. Olyan értékeké, mint a szabadság és az egyenlöség. Olyan elveké, mint az, hogy mindenkinek jogában áll dönteni a saját életéről." (Kis, 2000. 7. o.) A liberalizmus négy különböző formában jelent meg. $A z$ angol liberalizmus, mely a szabadság hagyományos felfogását, az állami kényszer alól való felszabadulást helyezte középpontba. A francia liberalizmus két irányzat 
ötvözete, a voltaire-i és montesquieu-i minimális állam gondolata, valamint a rousseau-i alapokon nyugvó individualizmus liberalizmusa. A Jó és az Értelem elvein nyugvó német liberalizmus, mely az államot eszközként fogja fel arra, hogy a polgárok biztonságát és jogait, valamint azt a rendezett keretrendszert biztosítja, amin belül a polgárok élhetnek a jogaikkal, miközben a külső veszélyeket és a tisztességtelen magatartást a Politikai Tervezö kiveszi a rendszerböl. Végül az amerikai liberalizmus, mely a kezdetektől szorosan összekapcsolódott a demokráciával. (Barta, 2009.)

Két irányzat különíthető el benne: az egyik a „lassez faire” elv biztosítása, valamint egy olyan társadalmi rend kialakítása, amely az ember mint gazdasági szereplő igényeit elégíti ki. A másik Rousseau és Thoreau gondolatiságára épít, melyben az „ember tökéletesithetö”, valamint egy olyan politikai rendszer alakítható ki, amely a „közérdek szolgálatának szerepét vállalja magára”. (Egyed, 2003.) Utóbbit szigorúan véve republikanizmusnak nevezzük.

\subsection{A természetjogi gondolat}

A szabadságjogok érvényesülése érdekében történő kölcsönös jogkorlátozás időszakának kezdete ez, amikor a filozófia kimondja, hogy az egyén vallásához és magántulajdonához az államnak nincs köze, de ennél tovább megy: az állam az a szereplő, amely nem pusztán köteles tartózkodni az egyes személyek magánéletébe való beavatkozástól, de törvényi garanciát kell azért vállalnia, hogy ezt más egyének se tehessék meg. A természetjogi iskola kimondja, hogy létezik a világban egy olyan jogrendszer, amely örök, és amely a hatályos, a szükebben vett állam által alkotott jog fölött áll: ugyanúgy érvényesek a társadalom tagjaira és annak vezetőire is.

A természetjogi elképzelés nem a felvilágosodáskor született. Jelen volt az ókori gondolkodásban és később a keresztény filozófiában is. Az ókori hagyományban az egyik klasszikus helye a társadalmi szerződés gondolatának és egy lehetséges természetjogi közelítésnek (bár természetesen történelmietlen lenne természetjogot mondani ebben a kontextusban) Platón Prótagórasz című dialógusa. A dialógus híres mítosza szerint Epimétheusz és Prométheusz az istenek megbízásából minden állatot különböző képességekkel láttak el, és végül az embernek nem maradt semmi. Ezért az embernek, az eredetileg Zeusz birtokában levő igazságosságot (dikaioszüné) adták mint képességet. (Platón, 1984.) Az igazságosság azonban „csak” arra jó, hogy ez alapján az emberek jól müködő közösséget alkossanak. Ez a gondolat folytatódott a 
sztoikus gondolkodóknál, akik az állam lényegét a közös igazságban, az egyetértésre alapozott közösségben látták.

Az ókori görögök a természetjogot a természetből, a középkori gondolkodók Istentől származtatták, a felvilágosodás filozófusai az észből vezették azt le. John Locke-ban, Rousseau-ban, Montesqieau-ben és Grotiusban az alapvető jogok állandósága, mindenekfölött való mivolta közös, de ezek a jogok Istentől és a természettől adottak. Csak a felvilágosodás végén vetődik az fel, hogy a természetjogot el lehet választani Istentől (és e gondolat felvetése is nagyon gyenge formában jelenik meg).

A klasszikus liberalizmus képviselöi egyetértenek abban, hogy az erkölcsi rend fenntartásához szükség van egy metafizikai létező fogalmára, csak ezt a metafizikai létezőt le akarják választani a szükségtelen dogmatikáról, a felesleges és a provincializmust konzerváló szabályokról. A szabályalkotás mércéjéül ezért választják a természetet, és ezzel ösztönzik a vallásbékét is a világi állam müködésében. Ebben a folyamatban vannak sikeres és kevésbé sikeres filozófiai és politikai gazdaságtani próbálkozások, de alapvetően egyetértés van abban, hogy a társadalmakat antropológiai összefüggésekből kell magyarázni. Ezt azért tartom fontosnak tisztázni, mert a neoliberalizmus szerződéselmélete nem mindenben támaszkodott az erkölcsi egység érdekében használandó természetjogi érvelésre.

Szentes Tamás (2006.) kimondja, hogy a klasszikus liberalizmus hagyományaival a neoliberalizmus nincs összhangban. A klasszikus liberalizmus filozófusai és közgazdászai korántsem vetették el az állami beavatkozást, pusztán azokat az állami beavatkozásokat tartották károsnak, amelyek csorbították az egyén szabadságát, és ezen keresztül felvetették a zsarnokság kialakulásának lehetőségét. Ha úgy tetszik: Smith, Ricardo, Mill és Malthus nem az egyén jövedelmét, hanem az egyén szabadságát féltették az államtól. Adam Smith a jogrendszer stabilitását a gazdasági folyamatok igazságosságával kívánta kiegészíteni, megalapozva ezzel a kartelltilalmat, a monopóliumok gazdasági erejével való visszaélés lehetőségének kiszürését, a munkavállalói érdekvédelmet, valamint a dolgozói szegénység ellen való fellépést.

\section{2. Állam és egyén viszonya, vallásszabadság és polgári jogok a XVII. századi liberalizmusban}

Míg az ókori demokráciában az individualizmus csak érintőlegesen jelenik meg Platónnál egyáltalán nem, Arisztotelész már foglalkozik vele -, az egyéni és kollektív 
szabadságjogok már egyértelmúen az embert helyezték a középpontba. Ennek időszaka a korai és a késői felvilágosodás, melyet a különböző népek eltérő időpontokban éltek meg, és ezért a korszak évszázados eltérésben jelentkezhet különböző országoknál.

A stabil intézményrendszeri építkezés mellett teszik le a voksukat, a kormányzatra mint ideális megfigyelőre tekintenek, és olyan rendszerek mellett érvelnek, amelyek képesek akkor is biztosan müködtetni az országot, amikor az rossz vezetők kezébe kerül. A kezdeti individualizmusnak talán a leglényegesebb eleme - és érdeme is egyúttal -, hogy olyan társadalmi rendszer létrehozását szorgalmazta, amely nem függ attól, hogy a benne mozgó egyének jók vagy rosszak. Nem kell jó vezetőt találni, mert az intézményrendszer stabilitása garantálja, hogy a társadalom jól lefektetett elvek alapján, szabályozott keretrendszerben müködik. (Hayek, 1948.)

Az egyén tudata az angoloknál nagyon erős, már-már természetes, hogy a magánügy, az egyén védelme az állammal szemben lelkiismereti és vallási értelemben is megjelent. Milton megfogalmazta azt is, hogy a ,hit annyira az egyén ügye, hogy a világi hatóságoknak még csak közelíteni sem szabad feléje” (Balla, 1926, 32. o.).

A mai liberalizmus egyik bölcsőjét jelentő angol polgári forradalom (1625-1690) előestéjén, a XVII. század végén megkezdődött az átalakulás: fellendült a kereskedelem és a hitélet. A protestantizmus térhódítására lelki értelemben a britek kivételesen jól felkészültek voltak, mint ahogyan arra is, hogy végül a forradalmuk bíróság elé állítsa Stuart Károlyt, arra hivatkozva, hogy a nép ugyanúgy Istentől kapja jogait, mint ahogyan az uralkodó a hatalmát, így a néphatalomnak joga van az igazságszolgáltatás keretén belül felelősségre vonni a zsarnokot.

A brit liberalizmus úttörő volt az európai klasszikus liberalizmus elveinek kialakításában. Mialatt Amerika még az angol gyarmatosítást élte át, NagyBritanniában a távolsági kereskedelem fellendülése a polgári osztály olyan anyagi érvényesülését hozta el, hogy a társadalmi átalakulás elkerülhetetlenné vált. A parlament kettészakadt haladókra és konzervatívokra, whigekre és torykra már az abszolutizmus korszakában. Utóbbiak az uralkodó Istentől származtatott jogait hangsúlyozzák, míg előbbiek a nép természetjogaira hivatkozva, a liberális demokrácia előhírnökei voltak. A liberalizmus első parlamenti képviselői 1601-től kezdődően még elvi vitákat folytatnak, akkor még I. Jakab király parlamentjében azonban Sandays, Coke, John Elliot, Seiden és Pym I. Károly trónra lépését követően a királypártiak és a haladók nyílt ellenségekként tekintettek egymásra. 1636-ra a király 
és a parlament közt nyílt szakadás történik, és nem pusztán politikai, de vallási értelemben is küzdelem volt, míg 1642-ben kitört a polgárháború. (Barta et. al, 2008.)

\subsection{Az államépítés célja és társadalmi haszna}

A királyt lefejezték, azonban a John Coke ügyvéd által képviselt közvádra joga volt válaszolni, és megvédenie magát. Bradshaw a népre hivatkozott, amikor a király azt a tekintélyt firtatta, amely a Westminster Hallba hurcolta. A perben és a forradalomban két államfelfogás és két jogfelfogás csapott össze. Stuart Károlynak abban igaza volt, hogy királysága nem választott, hanem örökös, ezer éve öröklődő királyság volt, azonban a forradalom akkor már nem engedett a népszuverenitás elvének kialakításából, és a klasszikus liberális elvekből az államépítésben. „Anglia népe, hála a forradalom eszméinek, három alapvető jogot nyert el: az elsö, hogy megválaszthatjuk kormányzóinkat; a második, hogy kötelességmulasztás esetén leválthatjuk öket; a harmadik, hogy magunk alkossuk meg a kormányunkat." (Burke, in: Ludassy, 1991. p. 11.)

A gondolat, hogy ha a királyok Isten által uralkodnak, akkor a nép Isten által követelheti a szabadságot, elvezetett odáig, hogy mivel a királyság a közös béke és biztonság garantálása céljából jött létre, a nép leválthatja azt a királyt, akiben már nem látja ennek garanciáit. Bár hosszú út vezetett el odáig, hogy nem pusztán az uralkodó leválthatósága, hanem a demokratikus intézményrendszer stabilitása, az állampolgárok egymáshoz való viszonya is kialakított keretek közt müködjön. Ezek megalapozása már a forradalmak korában megkezdődött. „A szabadelvüséggel kapcsolatos véres forradalmaknak az a legnagyobb és legszebb vívmánya, hogy az emberek nem bolygatják, hanem kölcsönösen tiszteletben tartják egymás világnézetét, és kormányzati elvek szerint szerveznek politikai pártokat.” (Balla, 1926. p. 7.)

Hugo Grotius azt mondja: „a jognak önmagában van a forrása, és éppen olyan megváltoztathatatlan, mint maga a természet és az ész". (Balla, 1926. p. 43.) John Locke gondolkodásában is ez képez kiindulási alapot, és szemben az abszolutizmust védelmező Thomas Hobbes-szal, aki amellett érvelt, hogy a természeti állapotban bárki megtámadhatott bárkit, és mindenki kénye-kedve szerint érvényesíthette veleszületett jogait, Locke e bizonytalan állapot feloldását az államalapításban látta. Azt mondja: a szervezett társadalom a zürzavaros természeti állapotból alakult ki, az emberek tudatos elhatározása útján, az emberek közös megegyezés útján lemondanak bizonyos jogaikról, hogy az önmaguk fölé kiterjesztett közhatalom biztosítsa 
számukra az élethez és a tulajdonhoz való jogot. Az állam funkciói pedig a közhatalom származékai.

Locke szerint az ember nem gyakorolhat hatalmat másik ember fölött, csak annak beleegyezésével, felfogása szerint önként, szabad elhatározásunkból lépünk be a társadalomba. Az állam alapítói ilyen értelemben szerződnek egymással, ők választják meg a közhatalom formáját, természetes jogaiknak és szabadságaiknak szerződésükön keresztül szabnak határt, és többségi döntéssel határoznak a közjóról. A népböl származó közhatalom törvényhozói, végrehajtói és föderatív hatalomra oszlik. A legmagasabb közülük a törvényhozói hatalom, ez tartja össze az egész közösséget. John Locke (1632-1704) a kormányról így ír: „Minthogy a törvények egyszerre és rövid idö alatt készülnek, amellett állandó és tartós hatályuk van, ami folyvást tartó végrehajtást igényel, másszóval egy vele foglalkozó készültséget: szükség van arra, hogy legyen állandóan egy hatalom, mely a kész vagy érvényben lévö törvények végrehajtásával van megbizva." (Balla, 1926. p. 48.) Célja, hogy lezárja a katolikusprotestáns szembenállást, kutatásának tárgya az, ami az emberek fejében van.

Locke az ember nevelhetősége és fejleszthetősége mellett érvel - szemben Hobbesszal -, a nevelésben szigorú elveket határoz meg: test és szellem együttes építését. Az ember munkája Locke szerint a saját tulajdona, ezzel rendelkezik, ezt tudja áruba bocsátani, ha ebben korlátozzák, az a tulajdonjogát sérti. E téren is szembehelyezkedik Hobbes-szal, aki szerint a munka csak egy lecserélhető tőkeforma, míg Locke jogként gondol rá, amit nem vitathatunk el az emberektől, sőt, a döntéshozóknak törekedniük kell arra, hogy a legszegényebbek, akik csak a munkaerejükkel rendelkeznek, tudjanak belőle pénzt keresni. „Értekezés a polgári kormányzatról” címü művében azt mondja: „Tehát a munka adja a föld értékének legnagyobb részét, nélküle az jóformán semmit sem érne". (Locke, 1986. p. 69.)

Az a gondolat is Locke-tól származik, hogy minden ember tulajdonosa a saját testének és keze munkájának. Az emberek egyenlőtlensége a tulajdonosok közti egyenlötlenséget jelenti Locke szerint. „akár földbirtokosok, akár kereskedők, bankárok vagy egyszerü munkások, akik csupán munkaerejük és munkaszerszámaik tulajdonosai”. (Polin, 1960. p. 272. 1.)

Ahogyan a kezdeti zürzavaros, természeti állapot feloldását és az emberképet tekintve is teljesen eltérő világképeket találunk, úgy a munkaerőre és a munkavállaló jogaira tett megállapítás is homlokegyenest mást mond Locke és Hobbes elméleteiben. Mialatt Locke amellett érvel, hogy jogunkban áll eladni a munkaerőnket, és az államnak 
kötelessége biztosítani, hogy akinek csak a munkaereje képezi tulajdonát, az értékesíthesse, és ily módon anyagi javakhoz juthasson, Hobbes úgy látja, hogy lecserélhetö és eldobható munkaeszközökkel van dolgunk, amikor a munkapiaci szereplöket nézzük. „Az embernek-csakúgy, mint minden másnak-értékét az árával mérjük.” (Hobbes, 1970. p. 76. 1.) „Mert az emberi munka, éppúgy, mint minden más dolog - áru, melyet haszonnal ki lehet cserélni.” (Hobbes, 1970. p. 210. 1.)

\subsection{A kereskedőtársadalom mint morális érték és értékképző intézmény Smithnél}

Adam Smith szerint minden társadalom kereskedőtársadalommá válik. Nála morális töltete van a piacgazdaság folyamataiba való bekapcsolódásnak. A polgárosodás alapköveként tekinteni a kereskedelemre gyakorlatilag a hayeki gondolatot megelőző lépcsőfokon áll: a piac felelősségvállalásra tanít. A vágyak kielégítése, a rossz elkerülése, az a tény, hogy a piac bünteti azt, aki nem gondolkodik hosszú távon, mind azt segíti elö, hogy az egyén tevékenysége során olyan folyamatokat mozdítson elö, amely a társadalom javát szolgálja.

A piac ebben az értelemben az értékrend védelmében segíti az embereket, hogy hozzáigazodjanak a folyamatokhoz, a teljesítményelvnek alárendelve kell müködtetni a piacot. Ez olyan értékrendet ad egyénnek és társadalomnak, amelyben a gazdasági irányvonalakhoz igazodó vállalkozó, a munkavállalói jogokat tiszteletben tartó munkáltató, és az alapvető jogokat minden körülmények közt védelmező állam alkotnak egységet.

Adam Smith (1723-1790) is harmóniát kívánt teremteni: küzd a társadalmon belüli igazságtalanságok ellen, a jogegyenlőtlenségek felszámolásáért. A nyomorban élőket a jogaik kiterjesztésén keresztül kívánja felemelni, a társadalom összhasznának növekedésével érvel, amikor a nyomor felszámolásáról ír: egy társadalom Smith szerint nem emelkedhet fel, amelyben a többség nyomorban él. „Nincs társadalom, amely virágzó és boldog tudna lenni, ha tagjainak messze legnagyobb része szegény és nyomorult. A méltányosságon kívül, azoknak, akik az egész nemzet táplálékáról, ruházatáról és lakásáról gondoskodnak, birtokolniuk kell saját munkájuk termékének azon részét, amellyel önmagukat türhetően táplálni, ruházni és elszállásolni tudják." (Smith, 1776, 1977. vol. 1. p. 88.)

A társadalmi mobilitás előmozdításáért küzd, és azért, hogy a munkavállalókat becsületesen megfizessék. Nagyon is gyakorlati ember volt, a hétköznapokból szerezte 
tapasztalatát, a monopóliumok felszámolásáért emelt szót, mai fogalmi keretek közt azt mondanánk, hogy a gazdaság dinamizálását tüzte ki célul, amikor a kisvállalatok (tümanufaktúra), valamint a verseny felszabadítása mellett érvelt. „Saját munkája olyan tulajdona az embernek, amely minden más tulajdonának legföbb forrása, s mint ilyen a legszentebb és legsérthetetlenebb. A szegény ember minden atyai öröksége a karja ereje és a keze ügyessége; akadályozni öt abban, hogy ezzel az erejével és ügyességével embertársainak ártalma nélkül a legjobb belátása szerint éljen, egyenlö a legszentebb tulajdon nyilvánvaló megsértésével." (Smith, 1776, 1977. vol. 1. p. 172. 1.) - ezt a céhtörvényre mondta Smith, és arra, hogy a szegény ember szabad munkaerőáramlásból való kizárása az ő szegénységét termeli újra. Sérti a jogait és korlátozza a gazdagodásban.

Smith a „Vizsgálódás a nemzetek jólétének természetéről és okairól” című művében hangot ad annak is, hogy a monopóliumokat erősítő törvényeket támogató parlamenti képviselöket elismerés övezi majd a nagytőkések körében, és a monopóliumok lebontásáert dolgozó politikusokat el fogja érni a gazdaság legbefolyásosabb és legfajsúlyosabb üzletembereinek mocskolódása, holott utóbbi a becsületes politikusi magatartás.

Smith a polgárosodás zálogaként tekint a kereskedelemre, a nemzetközi gazdaságra pedig mint a béke megteremtőjére, hiszen amelyik országgal kereskedelmi kapcsolatokat létesít egy társadalom, azzal közös érdek keletkezik, megszünik a háborús érdek. „Smith (Hume-hoz képest) pozitívabb szerepet tulajdonit az észnek, mint a társadalmi intézmények épitöjének." (Macfie, 1959. p. 217. 1.) Valószínüleg ezért hisz abban töretlenül, hogy az ember alkotta intézményrendszerekből tanulnak a társadalom tagjai, és nem pusztán hatékonyságuk vagy vállalkozásra való hajlamuk, de morális érzékük is fejlődik.

A piacgazdaságban és a lebontott nemzetközi kereskedelmi korlátokban a szabadság és a nagyobb jólét megteremtését látta. „Bolondnak és elbizakodottnak” tartja azokat a politikusokat, akik úgy gondolják, hogy a gazdaságot tervezhetik, a tőkemozgásokba való beavatkozást is rombolásként definiálja. Etikai kérdésként közelíti meg a gazdasági szerepeket, azt mondja, az együttérzés minden emberben ott lakozik, ehhez képest fontos megállapítást tesz, amikor - mintegy mikroökonómiai elemzésként bemutatja, hogy a kisvállalkozóktól származó javak, amelyek a boldogulásunkat és a nemzet gazdagodását szolgálják, nem a cégvezetők jószándékának, hanem önös érdekeinek eredményei. 
Smith olvasatában az államnak „három nagy fontosságú (...) kötelességet (...) kell szem elött tartania. Elöször: a társadalom megvédésének kötelességét más független társadalmak eröszakossága és betolakodása ellen; másodszor: azt a kötelességet, hogy a társadalom minden tagját valamelyik más tagjának igazságtalansága vagy elnyomása ellen lehetöség szerint megvédje, illetöleg azt a kötelességet, hogy kifogástalan igazságszolgáltatást vezessen be; és harmadszor: azt a kötelességet, hogy olyan közmüveket és közintézményeket létesitsen és tartson fenn, melyek létesitése és fenntartása sohasem állhat egy vagy több egyén érdekében, mert ezeknek nyeresége sohasem fizethetné vissza valamely egyénnek vagy az egyének kisszámú csoportjának költségeit" (Smith, 1776, 1977. vol. 1 p. 203. 1.)

A piaci folyamatokba való beavatkozást mélyen elvetette, a versenyszabályozást, mai szóhasználattal, a kis- és középvállalatok piaci lehetőségeinek megteremtésére, a monopóliumok visszaszorítására kívánta fordítani. Gazdaságfilozófiájában a monopóliumok korlátozása, a gazdasági előny túlzott mértékének visszaszorítása, és a monopolhelyzettel való visszaélés megakadályozása az egyik legfontosabb elem. „Smith elitélte a nagy részvénytársaságokat és kereskedelmi monopóliumokra épült nagy magánvállalkozásokat is. A közvetlenül irányitó tulajdonos-managert részesítette elönyben.” (Fekete, 1997. p. 9.)

„A liberális gazdaság-és morálfilozófia eredeti szándéka annak bizonyitása volt, hogy a morális személy az egyedüli elmozditója a jólétnek és önkéntes társulása legföbb támasza természetes szabadságainak, ehhez képest túlságosan könnyen áldozta fel az embert elöször a materiális szükösség miatt a gazdasági racionalitásnak, majd morális érzéketlensége miatt a politikai hatalomnak." (Fekete, 1997. p. 11.)

Ehhez a gondolathoz Smithnek szüksége volt a Locke-i hagyományokra, és arra a szilárd hitre, hogy az ember nevelhető, tanítható. Az erkölcs és a felelősségvállalás értékei átadhatók már gyerekkorban, sőt, John Locke szigorú nevelési elvein keresztül Smith még azt is okkal feltételezte, hogy az iskolarendszernek köszönhetően az egyén nem pusztán erkölcsössé, de fegyelmezetté is válik, ami önmagában elörevetíti egy dolgos, szabálykövető, és kihívásokra válaszokat kereső polgár képét.

Smith a piaci folyamatokba való be nem avatkozás mellett érvelt, ugyanakkor a tisztességtelen piaci magatartás visszaszorításában látta a gazdaságstratégiai tervező feladatát: „Bolond és elbizakodott volna az az államférfi, aki tervezni akarná a gazdaságot. Ilyen feladatot veszélyes volna rábízni nem csak egyetlen személyre, de bármely tanácsra vagy szenátusra." (Smith, 1776, p. 450. 1.) 
Szemlélete szerint a gazdaságstratégiai vezetés célja „gondoskodni az emberek számára bőséges jövedelemröl vagy megélhetésről, pontosabban lehetővé tenni számunkra, hogy a maguk jövedelméröl vagy megélhetéséröl gondoskodjanak" (Smith, 1776, 1977. vol. 1. p. 449.) A kormányzat feladata „ellátni az államot vagy a nemzetközösséget megfelelö bevétellel a közszolgáltatások számára”. (Smith, 1776, 1977. vol. 1. p. 3-4.) Ez pedig azt jelentette, hogy az egyéneket hagyni kell vállalkozni és dolgozni: nem paternalista értelemben tekintett az állam gondoskodó funkciójára, hanem a politikai és gazdasági szabadságjogok garanciájaként.

A vállalkozások és a piac szabadságán túl a tőkemozgások szabadsága mellett is érvelt, szerinte a tőkemozgásokba való beavatkozás „lelassitja a társadalom haladását a tényleges gazdagság és nagyság felé”. (Smith, 1776, 1977. vol. 2. p. 208.) Mindezek mellett Smith azt is kimondta, hogy „A gazdagoknak hozzá kell járulnia a közös kiadásokhoz" (Smith, 1776, 1977. vol. V. II, I) ${ }^{7}$. E kijelentés mutatja, hogy Smith a jobb anyagi helyzetben levők társadalmi felelősségvállalását, vagy egy nagyobb mértékü rész vállalását tartotta kívánatosnak a közös teherviselésböl.

„A gazdaság a természet nyelvén beszél az emberhez” - mondja Smith, párhuzamot képezve a természetjogi iskolával a gazdaság terén. (Smith, 1776, 1977. vol. 1. p. 26.) A gazdaság és a természet szerepe nem pusztán az elméletben, a gyakorlatban is közel állt egymáshoz: a brit pénzügyi és gazdasági infrastruktúra építésében jelentős szerepet játszottak természettudósok, Isaac Newton például az állami pénzverde vezetőjeként.

Newtonnak - John Locke jó barátjának - köszönhetően fogalmazódik meg, hogy a gazdaság úgy működik, akár a természet, a bolygók úgy keringenek a Nap körül, ahogyan a kereskedelmi hegemón körül keringenek a gazdasági partnerei. A távolsági kereskedelemre nézve ugyanazok a szabályok érvényesek, mint a nemzetgazdaságon vagy az emberi kapcsolatokon belül: az erkölcsösség fontos. Ahogyan a Nap tömege nem csökkenhet, úgy nem szabad csökkenteni a pénz értékét sem: ez az infláció elleni fellépést jelenti. Ha az állam másként tenne, meglopná az embereket: mintha lefaragna az aranyból, ami a pénz értékét képezi, ez pedig erkölcstelen volna.

Adam Smith megfogalmazta az abszolút előny fogalmát, és azt, hogy a nemzetközi kereskedelem mindkét partner számára előnyös. Smith a nemzetközi kereskedelmet

\footnotetext{
${ }^{7}$ https://inveritascrescentes.wordpress.com/2012/02/08/adam-smith-the-most-misquotedeconomist-of-our-time/
} 
éppolyan fontosnak tartotta, mint a kereskedelem többi formáját. „Ha minden nemzet a liberális szabad kereskedelem elvén kereskedne egymással, szabadon importálna és szabadon exportálna, akkor hasonlóak lennének, mint egy nagy birodalom provinciái." (Smith, 1776: IV.v.b.39. in: Schumacher, 2012. p. 62.) A munkamegosztás növeli a termelés mennyiségét azonos mértékben felhasznált munkaerő mellett, így minél nagyobb a specializáció mértéke, annál nagyobb a növekedés. Ennek oka, hogy a munkamegosztásból következő specializáció nem pusztán kvantitatív, de kvalitatív növekedést is okoz. (Schumacher, 2012) Smith „hitte, hogy az áruk szabad kereskedelme mellett a termékeket ott termelnék, ahol az ö abszolút munkaköltségük a legalacsonyabb”. (Schumpeter, 1954. p. 374.) Ezt nevezzük ma az abszolút elönyök tanának.

Smith elmélete szerint a növekedés korlátja a piac mérete, így amennyiben növekszik a piac, nagyobb gazdasági növekedést tudunk elérni. A kölcsönösen előnyös nemzetközi kereskedelemben minden fél többet tud eladni, azonban járulékos haszon, hogy technológiai tudást is átadnak egymásnak a partnerek, amelynek szintúgy jólétnövelő hatása van. (Schumacher, 2012.) „A hazai fogyasztásra szánt importtermékek lehetö legkisebb volumenre való csökkentése, és a hazai ipar termékeinek exportra szánt mennyiségének lehetö legnagyobbra való növelése. Ez két motor az ország gazdagságának növelésére, ennek érdekében az importot korlátozni, az exportot ösztönözni kell.” (Smith, 1776, IV.1. p. 35.)

Smith belátta, hogy az országok különböző tulajdonságokkal rendelkeznek, a „,termöföld, a természeti környezet, valamint az intézményi keretrendszer és a jogrendszer tekintetében" (Smith, 1776, III.iv.20, IV.ix.41. in: Schumacher, 2012. p. 63.), ezeken felül arra nézve is tett megállapítást, hogy gazdag és szegény ország közötti kereskedelemben a gazdagabb ország nagyobb arányban profitál a gazdasági kapcsolatokból, mint a szegényebb. A nemzetek közti verseny éppúgy a leghatékonyabb nemzetet hozná ki győztesként a versenyből, mint a hazai termelők versenyéből a nemzetgazdaság. A fentiek egyúttal azt is jelentik, hogy a nemzetközi kereskedelem nem pusztán jólét-, de hatékonyságnövelö tulajdonsággal is rendelkezik. Ozay Mehmet Adam Smith nemzetközi kereskedelemelméletét „,naiv elméletnek” bélyegezte (Mehmet, 1999. p. 47.). Bár kétségtelen, hogy az azóta eltelt közel két és fél évszázad jelentősen formálta a nemzetgazdaságról, piaci kudarcokról, fejlődési modellekről és nemzetközi gazdaságról alkotott képünket, én vitatkoznék Mehmettel. „Smith nemzetközi kereskedelemelmélete ugrókő volt a szofisztikáltabb elméletek 
számára, mint David Ricardo komparatív elönyök tana, vagy a Hechscher-Ohlin modell”. (Staley, 1989. p. 52.) Olyan gazdasági törvényszerüségekre világított rá alapvetően természettudósként, amivel lényegében lefektette a klasszikus politikai gazdaságtan alapjait, számos előremutató kutatásnak megágyazva ezzel.

Túl az alapjogi és gazdasági tézisen, a szolidaritás és a politikai szabadságharcos is megszólalt Smithből: „A polgári kormányzat, amennyiben azt a tulajdon védelmére állitják fel, valójában a gazdagnak a szegénnyel szembeni védelmére állitják fel, vagy azoknak, akiknek van valami tulajdonuk, szemben akiknek semmijük nincs." (Smith, 1776, 1977. vol. 2. p. 236.) Smith is ennek megváltoztatása mellett érvel. A nincstelenek tömegei a klasszikus liberalizmus időszakában morálisan igazolható társadalomszervezési alapelvek megfogalmazására kötelezték a kor filozófusait.

Nem pusztán a védtelenek érdekében való cselekvés, de az egyén állammal szembeni védelme lettek a társadalomszervezési ajánlat alapelvei. „A brit törvényhozás, az alkotmány alapelveinek megsértésével, olyan emberekre vet ki adót, s ezáltal olyan emberek gazdasági cselekvéseinek szabadságát korlátozza, akiktöl ugyanakkor megtagadja a politikai reprezentáció jogát.” (Smith, 1776, 1977. vol. 2. p. 471.) A „no taxation without representation” tengeren túli elvének felállítása a Brit Birodalommal szemben, ebben a gondolatban gyökeredzik. Amennyiben az ember hozzájárul adófizető polgárként az infrastruktúra létrehozásához, fenntartásához és fejlesztéséhez - vagyis az állam müködését finanszírozza -, úgy joga van beleszólni abba, mire fordítsák a pénzét.

\subsection{Az amerikai liberalizmus}

„A szabadság fáját időröl időre hazafiak és zsarnokok vérével kell öntözni.” (Jefferson, in: Ludassy, 1991. p. 45.) Locke szerint, ,egyszer az egész világ Egyesült Államok volt”. Ez azt a képességet jelenti, hogy egy nagyobb területi egységet sokszínü társadalommal és akár régiónként eltérő szabályozásokkal, infrastrukturálisan és államigazgatási értelemben egyben lehet tartani.

$\mathrm{Az}$ amerikai liberalizmus első képviselői a tulajdonjogra és a politikai szabadságjogokra támaszkodva építették fel a társadalomszervezési elveiket. „Minden ember tulajdonos a társadalomban, és joga van a társadalmi tökéböl részesülni”. (Ludassy, 1991. p. 27.) Az egyéni és kollektív szabadságjogok védelme az állam legfőbb feladta, és ennél tovább nem is merészkedhet az egyének privát életében. Sem vallásgyakorlásukat, sem a szabadságjogaik gyakorlását nem korlátozhatja, sőt, „(...) 
az állam dolga éppen az, hogy az egyén jogainak érvényt szerezzen.” (Kis, 2014. p. 159.) Az állam feladatait a közszolgáltatások ellátásában látják, azonban az adókat igyekeznek a minimális szintre csökkenteni: „...csökkenteni tudtuk a felesleges hivatalok számát, a szükségtelen intézményeket és költségeket, és ezáltal meg tudtuk szüntetni belső adóinkat.” (Ludassy, 1991. p. 65.) - mondta Thomas Jefferson második beiktatási beszédében, 1805. március 4-én. Amellett érvel, hogy az állam csak olyan mértékben adóztathatja meg az egyént, amelyen keresztül a közjavak biztosítását el tudja látni.

A klasszikus liberalizmus bízik a polgárokban, bízik abban, hogy az ember tanul a piaci folyamatokból, azokból az élményekből, amelyek érik. Ebből adódóan bízik abban, hogy a szabadságjogok megléte mellett tud csak jól müködni egy közösség. „(...) mivel az igazságot és az értelmet nem tudták legyőzni a meghamisitott tényekre alapozott téveszmék, az igazságra törekvö sajtónak nincs egyéb jogi korlátozásra szüksége. A közvélemény itélete az összes érdekelt fél meghallgatása után helyesbiteni fogja a téves érveléseket és nézeteket, és más választóvonalat nem kell húzni a sajtó felbecsülhetetlen értékü szabadsága és demoralizáló szabadossága között, ha lennének is ezen felül olyan helytelenségek, amelyeket ez a szabály nem zaboláz meg, a közvélemény feladata, hogy a cenzor szerepét játssza." (Jefferson, in: Ludassy, 1991. p. 69.) A nevelés szerepe itt is kivételesen fontos. A sajtószabadsággal való visszaélések kiszürésére kizárólag az a társadalom képes, amely nem pusztán befogadni és értelmezni tudja azt, amit olvas, hanem kritikai gondolatokat is megfogalmaz.

Az önkormányzatiság és a szubszidiaritás elve is megjelent már a XIX. századi liberális gondolkodásban, különösen az Egyesült Államokban. Az a gondolat, hogy a polgároknak közük van ahhoz, ami velük történik, és joguk van irányítani a saját életüket egyéni és közösségi szinten, megnyilvánul a lokális intézményépítésben is. „ $A$ megyéket akkora területekre kell osztani, hogy minden oda tartozó polgár össze tudjon gyülni és személyesen határozzon akkor, amikor összehívják öket. Rájuk kell bízni kerületük kormányzását a kizárólag örájuk tartozó ügyekben. Minden területben válasszanak maguk közül egy bírót, vegyék kezükbe a rendörség, a helyi katonaság, a polgárörség, az iskola ügyét, gondoskodjanak saját szegényeikröl, a területükön keresztül haladó közutakról (...)” (Jefferson, in: Ludassy, 1991. p. 75-76.)

A szabadságával élni tudó, felelős egyén az az emberkép, amelyből a XIX. század amerikai liberális gondolkodói kiindulnak. A társadalmi és pénzügyi tudatosságot 
feltételezik az emberekről és a közösségekről, felvetik a költői kérdést, hogy „,van-e jogunk másik korban élö embereket kötelezettségekkel terhelni" (Ludassy, 1991. p. 46.), egyúttal választ is adva: csakúgy, ahogyan az intertemporális választások esetén, a racionális egyén nem választja a jelenbeli túlfogyasztást, mert tisztában van vele, hogy a jövő készleteit éli fel.

\subsection{Szabad társadalom - szabad kereskedelem - a XIX. századi brit liberalizmus a klasszikus angol politikai gazdaságtanban}

A XIX. századi liberalizmust a gazdasági és politikai szabadságjogok kiterjesztése, valamint a társadalom müködtetéséhez szükséges liberális alapelvek lefektetése jellemezte. A társadalomszervezést az erkölcsi és jogi szabályokhoz való igazodás hatotta át, a gazdaságstratégiai tervezést pedig az önszabályozásra képes piac szemlélete.

Az angolszász klasszikusok másik nagy alakja a komparatív előnyök elméletét kidolgozó David Ricardo. Az 1817-ben publikált „Politikai gazdaságtan és adózás alapelvei" címmel megjelent mủvében gyakorlatilag a modern közgazdasági gondolkodás legfontosabb alapelveit írta le. A komparatív elönyök elmélete azt mondja, hogy két gazdasági partner - anélkül, hogy növelné az inputráfordítást, pusztán a specializációnak és a kereskedelemnek köszönhetően - nagyobb jólétre tud szert tenni, mintha izoláltan próbálnának meg előbbre jutni. (Formaini, 2004) ${ }^{8}$

Ricardo számszerüsített példán keresztül mutatja be a hatékonyságnövekedést és azt, hogy a relatív alacsonyabb költséggel (alacsonyabb határ- és alternatív költséggel) termelt jószágot megéri exportálnia egy adott nemzetgazdaságnak. (Meoqui, 2014) Ebben a modellben azonban a munka az egyetlen termelési tényező. A HeckscherOhlin modell ennél tovább lép, mert a munkaerőn kívül több inputtényezőben gondolkodik, és nem pusztán a termelési tényezők relatív bőségét, de a technológiát is figyelembe veszi. (Bajona-Kehoe, 2006) Gupta 2009-es cikkében rámutatott, hogy az egyes kereskedelemelméletek a gyakorlathoz képes túl leegyszerüsített modellekben gondolkodnak, így elemzéseinkben a Smith által felvázolt abszolút előnyök, a Ricardo által megalkotott komparatív előnyök fogalmára, valamint a porteri elmélet szerinti kompetitív előnyök elméletének szintézisére van szükségünk. (Gupta, 2009.)

\footnotetext{
${ }^{8}$ https://www.dallasfed.org/ /media/documents/research/ei/ei0402.pdf
} 
Közös a fenti elméletekben, hogy egy vámok nélkül müködő, az áruk szabad piaci mozgását lehetővé tevő nemzetközi kereskedelemben valósulhatnak meg, hiszen mindegyik hatékonyságnövelésről, költségoptimalizálásról, kezdetben is létező előny kihasználásáról beszél. A védővámok - melyekről értelemszerűen nincs szó a fenti modellekben - ezeket a hatásokat torzítanák, és ceteris paribus jólétcsökkentő hatással járnának. Történelmi távlatból nézve: előkészítették a gazdaságot és a társadalmat arra, hogy megszülethessen a szabadkereskedelmi megállapodások elmélete és az általuk szorgalmazott gyakorlat, és talán egyszer a közös, nemzetközi valuta is.

A klasszikus politikai gazdaságtan másik jelentös alakját, Thomas R. Malthust, a szegény társadalmi csoportok iránt érzett érzékenysége, és az általa éhínségek idején leginkább veszélyeztetettnek tartott csoportokra való odafigyelése vezette arra a következtetésre, hogy a gazdaságpolitikai döntéshozóknak törekedniük kell a béke és az „egyenlő költekezés” megőrzésére. Adam Smith szintúgy a társadalmi igazságosság igényét támasztó liberális teoretikusok táborát gyarapítja. Felemelte szavát a munkásosztály mellett, és érvelt a monopóliumok kialakulásának káros társadalmi hatásaira - amely lényegében a tőke nagymértékü koncentrációja, a piac spontán torzulása. (Szentes, 2006.)

\subsection{Mill és a XIX. század második felének liberalizmusa}

1848 után új társadalomfejlődési folyamat indul el, a korszakban mindhárom eszmerendszer nagy fejlődésen megy keresztül. A liberalizmus képviselői közt John Stuart Mill állítása az volt, hogy lehetséges a piac és a társadalom olyan szervezése, amelyben a piaci folyamatokat tekintve a szabadságot hagyják érvényesülni, az elosztás tekintetében azonban nem. Ezt nevezi Mill társadalmi igazságosságnak. Ha úgy tetszik, Mill olyan, mint egy XIX. századi harmadikutas gazdaságpolitikus. A piacon - Mill szerint - a természet törvényei érvényesülnek. Úgy látja, az erkölcsi érzületet meg kell erősíteni, és ezt beépíteni a piaci szereplőkön keresztül a folyamatokba.

„E tanulmány célja, hogy felállítsunk egy igen egyszerü alapelvet, mely tökéletesen alkalmas arra, hogy szabályozza a társadalomnak az egyénnel szemben alkalmazott ellenörzö és kényszeritő tevékenységét, akár jogi tevékenység keretében kimért fizikai eröszak, akár a közvélemény erkölcsi kényszere ennek az eszköze. Ez az elv a következö: az önvédelem az egyetlen olyan cél, amelynek érdekében az emberiségnek - kollektívan vagy egyénileg - joga van beavatkozni bármely tagja cselekvési 
szabadságába. Az egyetlen cél, amelynek érdekében jogosan lehet egy civilizált közösség bármely tagjával szemben - akarata ellenére - eröszakot alkalmazni: mások sérelmének a megakadályozása. Az ö saját-fizikai vagy erkölcsi-java nem elégséges indok erre." (Mill 1983, p. 54) John Stuart Mill érvelése egyúttal azt jelenti, hogy a politikai és gazdasági szabadságjogok elvitathatatlanok, a társadalom és a gazdaság folyamatait az erkölcsre kell alapozni, az eröszakmonopólium pedig csak úgy müködik, ha az igazságosság vezérli.

Mill kiállt a nemzetközi kereskedelmi korlátok lebontása mellett, és az eurót mintegy másfél évszázaddal megelőzve, közös valutatát szorgalmazott. „Akárhogy is, annyi barbarizmus még mindig maradt a legcivilizáltabb nemzetek közötti kapcsolatokban is, hogy szinte az összes ország azzal hangsúlyozza nemzeti mivoltát, hogy önmaga és szomszédai nagy kényelmetlenségére, önálló valutát használ.” (Mill, 1848: III.20.10) Mill is védelmezi a munkás réteget, a nyomorból adó szenvedésre keresi a kiutat, sőt, ő még a kollektivizmust sem veti el, ha az milliók szenvedésének képes véget vetni. Alfred Marshall az „etikai erök” mellett érvel, és azt mondja, hogy a gazdaságirányításban, a szabad kereskedelem politikájának kialakításában más, „szigorúan véve nem gazdasági” tényezőknek is szerepet kell játszaniuk. David Ricardo a liberalizált kereskedelem feltétlen híve volt, de beépítette elméletébe azt az eshetőséget, hogy háború sújtotta ország esetén - vagy csak gazdasági dekonjunktúra okozta visszaesés után - indokolt lehet a honi gazdaság védelmében, államilag korlátozni az importot. (Szentes, 2006.)

\subsection{Republikánus vagy liberális elvek?}

A gazdaságelmélet mellett érdemes figyelni a politikai filozófiai összefüggésekre is. A republikanizmus a XVII-XVIII. századot uralta, a XIX. században köszöntött be valójában a liberalizmus korszaka. A korszak társadalmi és politikai vívmányai miatt (mint az egyéni és kollektív szabadságjogok megszületése, a demokratikus intézményrendszer, valamint a jogállam szélesebb körben való terjedése) úgy tủnik, mintha mindhárom évszázadot a liberális elemek jellemezték volna leginkább. (Kis, 2000.)

A klasszikus liberális gondolat a republikanizmus kritikájaként is megjelent. A liberális eszmerendszer az egyént helyezi a középpontba, elképzelése szerint a jó és a rossz végső alanya az egyén. Ez az etikai individualizmus tézise. Az egyén a végső autoritás: a végső felelősséget önmaga előtt ő viseli, hogy életmódja jó és értelmes 
legyen. Ezért az egyént a lehető legnagyobb szabadsággal kell felruházni. A republikanizmus szerint a honpolgári erények mozgatják az embereket, a közjó fölismerése és valóra váltása motiválja őket, akik a személyes érdekeiket a közérdek alá rendelik. A klasszikus liberalizmus első kétszáz éve sokkal inkább tekinthető a republikanizmus kétszáz évének, majd ezt a XIX. században felváltotta a liberalizmus, melynek teoretikusai nem hittek a honpolgári erényre alapuló politikában, az alapgondolat az volt, hogy az intézményeknek akkor is stabilnak kell maradniuk, ha azokat amorális emberek vezetik. (Kis, 2009.)

Az államépítésben és a társadalomszervezésben megjelenő erénytakarékosság elve azt jelenti, hogy a szabályokat és az intézményi keretrendszert úgy kell megalkotni, hogy a polgárok motiváltak legyenek a szabályok betartásában, ne kelljen őket folyamatosan megfigyelni, más szóval: úgy kell intézményeket alkotni, hogy a polgárok akkor is kövessék a szabályokat, ha kizárólag önérdek vezérli őket. A korai liberális elméletek elöször csak a piacra értették ezt az elvet, de később kiterjesztették a politikára is. A mérsékelt politikai készenlét tézise olyan politikai berendezkedés felépítését követeli a liberálisoktól, hogy amennyiben az egyén a szabadidejét értékesebbnek tartja a közügyekkel való foglalkozásnál, dönthessen úgy, hogy kimarad utóbbiak alakításából, és csak addig foglalkozik velük, amíg szavazatával lemond döntési jogköreiről parlamenti képviselője javára, hogy az hozza meg helyette a döntéseket a következő választásig. Ez a klasszikus liberálisok által szorgalmazott képviseleti demokrácia elméleti alapja. A negatív szabadság elve az egyént körülbástyázza jogokkal annak érdekében, hogy mások - vagy az állam - az egyén szabadságába ne avatkozhasson bele illetéktelenül. (Kis, 2009.)

A liberalizmus és a demokratikus politikai etika modelljének összeegyeztethetősége a kérdés, amikor a republikanizmust és a liberalizmust vizsgáljuk, és ugyan a liberálisok a stabil intézményrendszeren keresztül kívánják megvalósítani a társadalom javulását, a republikánusok pedig az egyének moralitásának javításán keresztül, ez nem jelenti, hogy a liberális gondolkodók, közgazdászok amorális egyénekben gondolkodtak volna. David Hume szerint az egyén természetes érzelmei közé tartozik a másik ember iránti együttérzés, és bár Adam Smith is megjegyzi, hogy „Ebédünket nem a mészáros, a sörfözö vagy a pék jóakaratától várjuk, hanem attól, hogy ezek a saját érdekeiket tartják szem előtt. Nem emberiességükhöz, hanem önszeretetükhöz fordulunk, és sohasem a magunk szükségéröl, hanem a rájuk váró elönyökröl beszélünk nekik." 
(Smith, 1959. p. 64). Ö maga is hitet tett az egyének morális egyenlősége, a tisztességes piaci magatartása és a polgárokkal való egyenlő bánásmód elve mellett. A republikanizmus tévedése, hogy az erények nem adhatók át, a liberalizmus tévedése pedig az, hogy az egyének kizárólag önérdekkövetők. A jogállam állítása az, hogy erényessé lehet - és kell - tenni mindenkit, az oktatási rendszer felel ezért. A republikanizmus éles határvonalat tart fenn erényesek és nem erényesek közt, képviselői úgy vélik, a határvonal nem átjárható. Ugyan igaz a megállapítás, hogy a „lassez faire világában mindenki beérheti saját érdekeinek követésével, az eredmény mégis a közérdek maximalizálása lesz” (Kis, 2000, p. 38.), ugyanakkor „a valóságosan létezö piac nem veszi le teljesen az erkölcsi mérlegelés terhét az egyénröl”. (Kis, 2000. p. 39.) Ilyen eset például a környezetvédelem kérdése, vagy a minden értelemben vett hosszú távú fenntarthatóság tesztje - legyen szó államháztartásról vagy az egyén saját életéröl.

Jeremy Bentham és James Mill úgy gondolták, hogy az egyén politikai magatartása mérhető a racionális gazdasági szereplöhöz, aki tökéletesen tájékozott, hasznosságot maximalizál. Ez a demokratikus politika piaci mintára való leírása. A választót úgy írják le, mint haszonmaximalizáló „fogyasztó”, aki a keresleti oldalon áll, a kínálati oldalon pedig a politikus, aki nem értékeli, pusztán végrehajtja a választók tömege által generált igényeket. A modell a választók és a képviseleti tisztségre pályázók preferenciáiból indul ki.

Jeremy Bentham, az utilitarizmus megalkotója a társadalom tagjainak boldogságát helyezi középpontba. A hasznosságok összemérhetőségét kutatja, a hasznosság-elv gyakorlatban való alkalmazhatósága mellett érvel: megadható egy kalkulus, amely alapján eldönthető, mi hasznosabb egy ember számára két dolog közül. A fájdalmak és örömök szerinte összemérhetők, azt kutatja, hogy mi az, ami a lehető legtöbb ember lehető legtöbb boldogságát hozza el. A vallást és az erkölcsöt nem csak hogy különválasztja, egyházkritikájában megfogalmazza, hogy a vallási dogmák mennyire ellent tudnak mondani az erkölcsösségnek.

A racionális döntéshozót, aki a saját, jól felfogott érdekében cselekszik, a klasszikus liberalizmus időszakában Jeremy Bentham úgy jellemezte, hogy minden boldogságot, amit az ember megteremthet, meg kell teremtenie, a gyötrelmeket pedig meg kell szüntetni. A mások öröméhez való hozzájárulást, vagy a kínjaik enyhítését is fontosnak tartotta, úgy érvelt, hogy ehhez minden nap hozzájárulhatunk. Úgy vélte, ha 
mások öröméhez hozzájárulunk, vagy ha segítünk a szenvedéseiktől, szomorúságuktól megszabadulni, az bennünket is boldogsággal tölt el.

Bentham az embert a társadalomba fizikailag beágyazott lényként tekinti, akinek az örömei és a fájdalmai nem csak azt határozzák meg, hogyan cselekedjen, de etikai értelemben is útmutatást adnak arra nézve, hogy mi a helyes, és hogyan kell cselekednünk. Ezt később hasznosságfogalomként kezdi el használni a közgazdaságtudomány. A szükös erőforrásokkal való gazdálkodás képessége, valamint a hasznosságmaximalizálás elöfeltétele, hogy az egyén az örömöket maximalizálni, a fájdalmakat pedig minimalizálni igyekszik.

Jean-Jacques Rousseau Benthammel és Millel szemben az etikai modell mellett érvel, melyben a választó felelössége kulcskérdés. A politikai döntések szerinte közösségi természetűek. A közjó nem elsődlegesen abban áll, amit a többség ténylegesen kíván, hanem abban, amit indokolt lenne kívánnia. (Kis, 2000.)

Immanuel Kant, kiegészítve Adam Smith és Jean-Jacques Rousseau elméleteit, az erkölcs és a szabadság közti kapocs elméletének kidolgozója. Ők hárman azok, akik az európai liberalizmust megjelenítik, mialatt Thomas Jefferson egyszemélyben megjeleníti az amerikai liberalizmust.

„A szabad akarat és az erkölcsi törvények hatálya alatt álló akarat tehát egy és ugyanaz. Ha tehát előfeltételezzük az akarat szabadságát, akkor már fogalma puszta felbontásából következik az erkölcsiség és annak elve." (Kant, ford. Berényi, 1991. p. 82.) „Azt állitom most, hogy minden akarattal biró eszes lényt a szabadság eszméjével is fel kell ruháznunk, s ennek jegyében képes csak cselekedni." (Kant, ford. Berényi, 1991. p. 83.) Kant azt mondja, hogy minden embernek más ember befolyásától mentesen kell tudnia cselekednie, és ez csak akkor sikerülhet, ha mindenkit felruházunk a szabadsággal.

A felvilágosodás német gondolkodója állítja, ha az ész segítségével az ész előírásainak eleget tudnánk tenni, megvalósítani eszméjét, az isteni művészetnek volna tekinthető. Értelmezésében a cselekedetek legalitását és moralitását is kell vizsgálni. Előbbit jogszabályi keretek, utóbbiakat az etikai törvények határozzák meg. „A szabadság e törvényei, a természettörvényektöl eltérően, erkölcsiek.” (Kant, ford. Berényi, 1991. p. 306.) Elképzelése szerint nincs ez másként az egyes államokkal sem.

Kant a polgári alkotmány követelményét állítja minden állam elé, és úgy látja, minden ilyennek köztársaságinak kell lennie. A szabadságot nem úgy definiálja, ahogyan előtte és utána számos esetben megtették, miszerint az egyénnek jogában áll mindent 
megtenni, amivel másnak kárt nem okoz, hanem úgy, mint jogosultságot. (...), „Inkább úgy kell magyarázni az az én külső (jogi) szabadságomat, hogy az: jogosultság, semmi más külsö törvénynek nem engedelmeskedni, mint amelyekhez megvolt a lehetöségem, hozzájárulásomat adhatni." (Kant, ford. Babits, 1985. p. 19.) Demokráciafelfogása is ebböl következik, „az uralkodás minden formája, mely nem reprezentatív, tulajdonképpen formahiba". (Kant, ford. Babits, 1985. p. 19.)

Kant beszélt a törvények univerzalizmusának követelményéröl, a háborúban betartandó emberiességi szabályokról, az államok belügyeibe való beavatkozás tilalmáról, a népek békés együttélésének, a fenntartható fejlődésnek előkövetelményeiről, és az államadósság tilalmáról is. „Nem szabad államadósságot csinálni a külső államüzletek vonatkozásában” (Kant, ford. Babits, 1985. p. 10.). Ez a klasszikus liberalizmus egy fontos pontja, és nem pusztán azért szükséges ezt tárgyalni, mert volt olyan korszak, amelyben a liberális demokráciák, a szabadság eszméjére hivatkozó gazdaságstratégiai tervezési ajánlattal nagy államadósságot generáltak. A gazdaságtörténet számos pontján bizonyosodott be azóta, hogy externális sokkoknak azok a nemzetgazdaságok képesek ellenállni, amelyek anticiklikus gazdaságpolitikát követve alacsony költségvetési hiánnyal és fenntartható államadóssággal működnek.

„Egy állam se engedjen meg magának egy másikkal való háborúban oly ellenségeskedéseket, melyek a kölcsönös bizalmat a jövendö békében szükségképp lehetetlenné tennék. Ilyenek az orgyilkosok (percussores), méregkeverök (vene fici) alkalmazása, a kapituláció megszegése, árulásra (perduellio) való bujtogatás az ellenséges államban" (Kant, ford. Babits, 1985. p. 12.) Ez az a megállapítás, miszerint „a békeállapotot először intézményesiteni kell”. (Kant, ford. Babits. p. 17.) Azt is meghatározta, hogy ,ilyen kezesség csak törvényes állapotban képzelhetö el”. Ez a gondolat később a nemzetközi jog egyik legfontosabb eleme lett: napjainkban az egyetlen jogszerü állapot a béke állapota.

A fentiek alapján a klasszikus liberalizmus teoretikusai és gyakorlati megvalósítói nagyon is közel jártak a társadalmi igazságosság, az egyén szabadsága és felelösségvállalása közti összhang megteremtéséhez, valamint a fenntartható fejlődés kívánalmaihoz való közelítéshez. Az erkölcs, az ember képessége az együttérzésre, a polgárok felemelkedésének lehetősége vezérelte őket, ennek kulcsát legtöbben az egyéni szabadságban és a nevelésben látták. A fő probléma nem az elméleti háttérrel 
vagy a szándékokkal volt, hanem azzal, hogy hiányoztak azok a gazdasági és technológiai eszközök, amelyek az erény kiterjesztését lehetővé tették volna.

A XIX. század liberalizmusának a megoldatlan társadalompolitikai kérdések és gazdasági értelemben vett igazságtalanságok vetettek véget. A nagyfokú tőkekoncentráció, a ma már dolgozói szegénységnek nevezett jelenség tömegessé válása, valamint a szabadjára engedett piaci folyamatok által generált anomáliák kihívásaira a klasszikus liberalizmus eszköztára nem nyújtott megoldást. Annak felismerése, hogy az ajánlat, amelyet az eszmerendszer megfogalmaz, úgy elméletben, mind gyakorlatban kudarcot vallott, a XX. század liberális gondolkodóira maradt.

A klasszikus liberális gondolkodók tisztában voltak azzal, hogy a spontán müködő piac számos olyan tökéletlenséget hordoz magában, amely társadalmi igazságtalanságokhoz és társadalmi csoportok emberi méltóságának sérüléséhez vezet. Ez a gondolat Smith, Ricardo, Malthus, Marshall és Mill írásaiban is megjelenik, csakúgy, mint a problémára való megoldáskeresés. Ők azt a típusú állami beavatkozásokat ellenezték, amelyek megzavarják a piaci müködést, nem azokat, amelyek segítik az önkorrekciós mechanizmust, vagy - ha ez sem lehetséges -, segítenek korrigálni, ami elromlott. (Szentes, 2006.)

Noha Mill úgy tartotta, hogy az adózás visszafogja a gazdasági hatékonyságot, mégis elismerte, hogy a közjavak - mint például az útépítés - biztosításában szerepet kell vállalnia az államnak. További érdekesség a klasszikus liberálisok köréből, hogy ugyan Smithre nagyban alapozzuk a lassez-faire ideológiáját, ő maga a fogalmat sosem használta munkáiban. (Young, 2014.)

Ebben a korszakban fektették le a kereslet-kínálat törvényeit, valamint a csereárak kialakulásának törvényszerüségeit. Ez az a típusú kereskedelem, amely állami beavatkozástól mentes, és amelyet lassez-faire-nek ${ }^{9}$ nevezünk.

A klasszikus liberalizmus tekinthető a gazdasági és emberi jogi liberalizmus egyfajta fúziójának. A természetjogokból vezette le az emberi jogok gondolatát. Azt az álláspontot képviselte, hogy a piac mechanizmusai, a lassez faire elmélete, valamint a jogegyenlőség mindenekfölött valók, és egymással összeegyeztethetők. A gazdasági liberalizmus megfelelő állami keretrendszerek nélküli működtetése híján azonban a

9

https://ischolarship.library.jhu.edu/bitstream/handle/1774.2/61409/Burgin\%20Laissez\%20Faire.pdf ?sequence $=1$ \&isAllowed $=y$ 
piaci kudarcok elvezettek odáig, hogy a liberalizmus válságba került, mely válság leginkább az I. világháborút követő két évtizedben mélyült el igazán.

\section{A XX. SZÁZADI LIBERALIZMUS - NEOLIBERALIZMUS ÉS ÚJLIBERALIZMUS}

\subsection{A klasszikus liberalizmus és a XX. századi liberalizmus közti átmenet}

A liberalizmus, bár politikai szabadságjogok kiterjesztését és vívmányait tekintve a XIX. század második felében élte fénykorát, a XX. század elejére ez a lendület megtört, az I. világháború után pedig két évtizednyi, mély válságot élt meg. Ennek a meghaladásához az 1938. augusztus 26-án kezdődött, ötnapos „Lippmannkonferencia” is hozzájárult. A Walter Lippmannról elnevezett, Párizsban rendezett esemény sokkal inkább tekinthető a neoliberalizmus születése pillanataként, mint a Mont Pélerin Társaság 1947-es alakulása (Dardot-Laval, 2013. 159.o.) A Nemzetközi Kulturális Együttmüködés Intézetében (az UNESCO elődje) megalapozta a neoliberalizmust, egyúttal új lendületet adva az eszmének, így biztosítva fennmaradását és azt, hogy a liberálisok konstruktív, működőképes gazdaságpolitikai és társadalompolitikai tervezetekkel állhassanak elő.

A konferencia eredményeként a neoliberalizmus több erővonal mentén, konfliktusok közepette születik. A rendezvény akkor még nem tette lehetővé, hogy „neoliberalizmus” és ,újliberalizmus” között világos határvonalat húzzanak, noha néhány francia résztvevő kifejezetten az utóbbi irányzatot vallotta magáénak. Míg Louis Marlio „szociálliberalizmusról”, addig Bernard Lavergne „liberális szocializmusról" beszélt. (Dardot-Laval, 2013. 160.o.)

Az „újliberalizmus” nem képezte a konferencia fő sodrát, holott az újliberalizmust magukénak valló gondolkodók és neoliberálisok jól kirajzolódott a különbség: előbbi csoport nem vetette el az állami beavatkozást - ezzel jelentős párhuzamot képezve a bő egy évtizeddel később megerősödő ordoliberálisok és a francia szociálliberálisok között, akiknek úttörője az 1940-ben megjelenő, „Grundlagen der Nationalökonomie” (A nemzetgazdaságtan alapjai) címü könyv szerzője, Walter Lippmann volt. (DardotLaval, 2013. 189.o.)

Slobodian 2018-ban úgy elemezte a XX. századi liberalizmust, hogy „a neoliberalizmus különféle, XX. század elsö felében kibontakozó irányzatokból tevődik össze. 
- freiburgi iskola (Walter Eucken, Franz Böhm);

- chicagói iskola (Milton Friedman, Aaron Director, Richard Posner);

- kölni iskola (Alfred Müller-Armack);

- genfi iskola (Wilhelm Röpke, Michael Heilperin)".

(Slobodian, 2018. in Antal, 2019. p. 114.)

A később kibontakozó gyakorlatok alapján úgy látom, a XX. századi liberalizmus alapvetően két korszakra tagolható, melyek a fenti négy iskola törésvonalai mentén szerveződtek. Az első a '30-as évek végén kezdődött korszak, valamint a '70-es évek közepén jelentőssé vált fejezet, melyből később az egész világra kiterjedő gazdaságstratégiai tervezési modell nőtte ki magát. A liberalizmus az elmúlt évszázadok során több olyan válságon keresztülment, amely arra sarkallta teoretikusait és gazdaságpolitikai irányának meghatározó alakjait, hogy újragondolják az eszmerendszer következő korszakát. „(...) a neoliberalizmus gyökerei a klasszikus liberalizmusra vezethetök vissza, annak is a gyakran „gazdasági liberalizmusként” emlegetett változatához. De az új irányzat kezdeti törekvései egyre inkább szembefordulnak az eredeti felfogással, míg végül a '70-es években kibontakozó neoliberalizmusban - ahogy fokozatosan rendszerként épül ki-már teljes a fordulat az ellentétes irányba." (Ágh, 2019. p. 27.)

A nagy gazdasági világválság teremtette helyzetre adott válasz alapozta meg a neoliberalizmust, azonban az is megfigyelhetö, hogy már az elején nézetkülönbség volt a közgazdászok között abban, hogy vajon „a klasszikus liberalizmus mind teljesebb elárulása" felelös-e az 1929-ben bekövetkezett összeomlásért, vagy maga a klasszikus liberalizmus az, amely nem képes kezelni a modern gazdaság kihívásait. Az előbbi nézőpont képviselői Robbins, Hayek, Rueff és Mises, az utóbbi álláspont mögé pedig Rougier és Lippmann sorakoztak fel. (Dardot-Laval, 2013. p. 164.) A törésvonal egyúttal az osztrák-amerikai iskola alapvonásait is meghatározza: a végsőkig ragaszkodni a klasszikus liberalizmus gazdaságot érintő elveihez. Éppen emiatt a Lippmann-konferencián arról szólt a vita, mit jelentsen a liberális fogalmi keret, és miben áll a XX. századi liberális gazdaságpolitika. Az újliberalizmus szolidaritást előtérbe helyező ága háttérbe szorult, mialatt a leszakadókat hátrahagyó neoliberalizmus fokozatos erősödésnek indult. 


\subsection{Az ordoliberalizmus}

A freiburgi iskola elvetette a lassez faire elvét, és előtérbe helyezte az emberiességi szempontokat, de a tengerentúlon már egy olyan neoliberális gazdaságpolitikát ismert meg a társadalom, amely a neokonzervatív társadalomszemlélettel ötvözve azt üzente a gazdaság szereplőinek: aki az állam segítségére szorul, morálisan alsóbbrendű, mint azok a honfitársai, akik képesek maguk boldogulni. A neoliberalizmus inkább egy közös ideológiai irányvonal (Venugopal, 2015.), azonban számos mellékága jött létre, elég csak a nemzeti sajátosságokra gondolni.

A német Wirtschaftswunder (Gazdasági csoda) e folyamat ellenkezőjét építette fel; alapját ugyanis az a törekvés adta, hogy a piacot és a szociális hálót egyszerre rendezzék, noha e célokat nem egyszerü integrálni: Walter Eucken (1952) fogalmazta meg ezt a célrendszert a „Rendek Interdependenciájaként”. (Interdependenz der Ordnungen) (Eucken 1952, 1990 p. 183 in Dardot-Laval, 2013.) Egyedülálló sikerei mellett olyan szociális háló épült a Német Szövetségi Köztársaságban, melynek alapjai a mai napig részét képezik német gazdaságtervezők elméleti kereteinek. (Lorch, 2013.) A neoliberalizmus, főképp a szolidaritás és a társadalmi szintü felelősségvállalás, a szociális háló eliminálása miatt rengeteg kritikát zúdított magára. Vele szemben a freiburgi iskola által létrehozott ordoliberalizmus éppen hogy egy stabil, modern jóléti államot hozott létre, fenntartható fejlődéssel kombinálva, amely a modernizációt és a társadalom széles rétegeinek felemelkedését is magával hozta, tette mindezt az emberi méltóság mindenekfölött való mivoltának elismerésével, sőt, feltehetőleg éppen miatta. (Grundgesetz für die BRD, 1949.)

A „gazdasági szabadság eszménye” (Hayek, 1951.) nem pusztán növekedést, jólétet, de méltóságot is hozott németek milliónak, a vasfüggönyön túl. A „liberális reneszánsz" indulása már korábban megkezdődött. Walter Lippman 1937-ben publikált egy cikket, melyben a klasszikus liberalizmus eszményeinek megerősítése mellett tesz hitet. Ez a cikk, majd később az 1938-ban rendezett Lippman-konferencia megteremtette a liberalizmus megújulásának lehetőségeit. (Dardot-Laval, 2013.) E lehetőséggel nemzetgazdaságok, filozófusok, közgazdászok és jogászok egymástól eltérő módon éltek. A Német Szövetségi Köztársaságban egy olyan irányzat született, amely közel hozta a polgárokhoz a klasszikus liberális elveket, elkezdte kiszürni a tisztességtelen piaci magatartást, felemelni igyekezett az addig elfeledett társadalmi csoportokat, és alapvető jogi-nem pedig szociális - kérdésként tekintett a szegénység legmélyebb szintjeinek felszámolására. 
A szándék, hogy „szüntessük meg a szegények és a gazdagok közötti ellenségességet”, valamint hogy ,a verseny segitségével elérhető a haladás és a nyereség - a szó legjobb értelmében vett társadalmasitása, és amellett fenntartható az egyén teljesitményre törekvése is" (Erhardt, 1957, 1990. p. 7.), alapjaiban változtatta meg a háború utáni Németországot. A gazdaság termelékenységének erösítése és a társadalmi igazságosság megteremtése egyszerre volt cél az ordoliberalizmus megteremtőinél. A verseny akadályozásának kritikája már az alapgondolatok közt megjelenik, a klasszikus liberális elveknek megfelelően nem azt tüzi ki célul, hogy az állam magára hagyja a gazdaságot, hanem azt, hogy az egyén önrendelkezését és alapvető jogait ne sértse müködésével. Erhardt szembenézett azzal, hogy a kor társadalmi viszonyai közt nem elképzelhető az állami szerepvállalás lényeges csökkentése, ugyanakkor az adócsökkentés célját ennek ellenére kitüzték.

Az ordoliberális iskola nem csak a gazdaság, de a demokratikus intézményrendszer helyreállítását is célul tüzte ki. „A jólét általános növelésével a gazdaságpolitika kétségtelenül értékes hozzájárulást nyújthat Nyugat-Németország demokratizálásához." (Erhardt, 1957, 1990, p. 11.) Az egyes társadalmi csoportok közti szakadék, valamint a különböző társadalmi csoportok egymással való szembenállásának felszámolását is fontosnak tekintették, ami - ahogyan az egykori kancellár fogalmaz - az osztályharc megszüntetéséhez vezet. A fogyasztás szabadságát kiterjesztő stratégia az egyéni szabadság és az önmegvalósítás útját kívánta biztosítani azok számára, akik korábban nem voltak képesek hatást gyakorolni a saját sorsukra, mert a gazdasági-társadalmi lehetőségeik szükösek voltak. Az ordoliberálisok a gazdasági humanizmust képviselték, egy gazdaságon túli elemet, az emberiességet tüzték ki a gazdasági és a társadalmi rendszer céljául. (J. Horváth, 2000) „A verseny a legeredményesebbnek ígérkező eszköz arra, hogy a jólétet megvalósitsuk és fenntartsuk." (Erhardt, 1957, 1990. p. 7.) Erhardt úgy látta: azoknak, akik önhibájukon kívül nem képesek a termelésben részt venni (idősek, betegek, a háború kárvallottjai), szolidaritásból segíteni kell, hogy méltó színvonalon élhessenek. Lemondanak az osztályharcról, és maguk mögött hagyják azt a gazdasági rendszert, amely nem tiszteli az emberi méltóságot és a polgárok jogait. A szabadversenyes gazdaság mellett teszik le a voksukat, az alapvető szabadságjogok kiterjesztése mellett kívánnak versenyt teremteni.

A jólét általános növelésével kívántak hozzájárulni Németország demokratizálásához, ennek egyik legerősebb lába az új gazdaságstratégiai tervezési szemlélet. Mintegy 
alaptörvényként tekintik a kartell-ellenes szabályozást, ami a KKV-szektornak nyújt teret. Ez a szemlélet a mai napig meglátszik a Német Szövetségi Köztársaság gazdaságán: a gazdaság dinamizmusát alapvetően a túlsúlyban levő kis- és középvállalatok adják, de szép számmal akadnak egyéni vállalkozók, mikrovállalkozások is. Az ötvenes években felvázolt gazdaságszerkezeti alapoknak mind a mai napig erős hatása van a Német Szövetségi Köztársaság gazdaságára. „Az e témakörben a 2016. évre adattal rendelkezö 24 uniós tagország közül az egy kkv-ra (kevesebb mint 250 fót foglalkoztató vállalkozásra) jutó átlagos árbevétel és hozzáadott érték Németországban és Ausztriában volt a legkiemelkedöbb, összefüggésben a kkv-k ezen országokban betöltött kiugró szerepével. "10 (KSH, 2018.) Az '50-es évek ordoliberális törekvései nem pusztán a vállalkozás szabadságának kiterjesztésében járt élen, de a demokrácia és a piaci folyamatok fogyasztói oldalának szempontjából is. „A fogyasztás szabadságát biztositó demokratikus alapjog logikus kiegészitése a vállalkozás szabadsága, hogy azt termelje vagy azt szüntesse meg, ami számára a piac adottságaiból, azaz az összes egyén szükségleteinek megnyilvánulásiból szükségesnek vagy eredményesnek igérkezik.” (...) „A demokrácia és a szabad gazdaság logikailag éppúgy összetartoznak, mint a diktatúra és az államilag irányitott gazdaság." (Erhardt, 1957, 1990. p. 11.) A célokat egyértelmüen az akkor már összeomlott Harmadik Birodalom működésével szemben határozták meg. Az NSZK gazdaság- és államépítésének úgy kellett nekilátniuk, hogy közben számos társadalmi és gazdasági kihívással néztek szembe. Az emberi méltóság tiszteletének helyreállítása, valamint a hosszú távú gazdaságstratégiai tervezés szemlélete jellemezte a II. világháborút követő időszakot Nyugat-Németországban.

Mindenfajta rövid távú látszatsikert megteremtő, tisztességtelen verseny- és gazdaságpolitikára nemet mondanak, igent mondanak viszont a valuta stabilitásának őrzésére, és annak mindennemü támadással szembeni megvédésére. Úgy kívánják növelni a jólétet, hogy a társadalom bizonyos rétegei ne mások kárára gazdagodjanak. A nemzeti valuta stabilitását felvették az alapjogok közé, ezért minden polgár jogot formálhatott arra, hogy az államot számonkérje ebben az ügyben. Az árak stabilitásának őrzése már csak azért is fontos, mert a német társadalom igen érzékenyen reagált ebben az időszakban az árak legcsekélyebb növekedésére is, ami a lakossági megtakarítások előjelét negatívra váltotta. (Erhardt, 1957, 1990.)

\footnotetext{
${ }^{10}$ https://www.ksh.hu/docs/hun/xftp/idoszaki/pdf/kkv18.pdf
} 
„Legföbb ideje, hogy fiatal demokratikus államunk biztos jövője érdekében ismét visszatérjünk az erény ösvényére.” (Erhardt, 1957, 1990, p. 13.) A mértékletességet helyezte előtérbe a kormányzati kommunikáció (ezzel alaperényt emelve a társadalomszervezési elvek közé): egyéni szinten a megtakarítások előtérbe helyezését a fogyasztással szemben - erről az útról sokan letértek. A liberális eszmerendszer történetében nem egyedülálló az ordoliberalizmus törekvése. A klasszikus liberalizmus képviselői is középpontba helyezték az erényt. „A jó princípium uralma, amennyire emberek ahhoz hozzájárulhatnak, belátásunk szerint nem érhetö el másképp, mint az erény törvényein alapuló és azokat támogató társulás létrehozásával és kiterjesztésével, úgy, hogy e társulásnak a maga teljes terjedelmében történö megvalósitását az ész az egész emberi nem feladatává és kötelességévé teszi." (Kant, 1974. $)^{11}$

Az '50-es években nem pusztán morális, politikai és társadalmi sikerek jellemezték a Német Szövetségi Köztársaságot. A lakosság lélekszáma rövid idő alatt 25 százalékkal növekedett, és a háború elötti legjobb évek életszínvonalánál is jobban élt. Nem pusztán munkát és kenyeret, de jólétet és méltóságot is biztosított a polgároknak a Német Szövetségi Köztársaság, ezzel pedig visszanyerte a világ bizalmát - írja Erhardt (1957.)

Ezzel a szemlélettel az ordoliberális gazdaság- és társadalomfilozófusok köre lényegében visszatért a klasszikus liberalizmus alapelveihez. Az olyan értékek újbóli felélesztése a második világháború után, mint az erkölcs, vagy az ókori görög filozófia által megfogalmazott erények újra emberarcúvá tették a liberalizmust, miközben egyéni és csoportos jogkiterjesztési folyamataik, valamint esélyegyenlőségért tett társadalomszervezési lépéseik sikerrel jártak. Már az '50-es évek végén egy másik Nyugat-Németországot találunk az elemzések alapján. A III. Birodalom rémtettei után ismét előkerültek azok a törekvések, amelyek a felvilágosodás-kori gondolkodókat is jellemezték. A társadalom harmóniájának megteremtése vált fő céllá.

A szubszidiaritás elve, az önkormányzatiság, a jószomszédi szemlélet, a valódi polgári beállítottság szorgalmazása mind egy emberségesebb társadalom kialakítását szolgálták. Olyat, ami elfordult a Harmadik Birodalom embertelenségétől, és olyat, amelyben egyetlen társadalmi csoport sem más társadalmi csoportok kárán kívánta érvényesíteni szabadságát. „,Minden okunk megvan arra, hogy bizalmatlanok legyünk

\footnotetext{
${ }^{11}$ http://mek.niif.hu/06600/06616/html/
} 
azok moralizmusával szemben, akik a szabadságot elitélik." (Röpke in J. Horváth, 2000, p. 18.) Ebben a szemléletben a polgárok biztonságát és szabadságát egyszerre garantálják, ami pedig különös pozitívuma ennek a korszaknak: az ország társadalomszervezői módot találtak arra is, hogy a polgárok egymás méltóságát és szabadságát is tiszteletben tartsák.

E célok eléréséhez szükséges volt a gazdaság állapotával való szembenézés, és annak felismerése, hogy a beruházási kedv alacsony volta miatt nem lesz lehetőség növekedni. 1952-ben és '53-ban a lakásépítési törvény jelentősen hozzájárult az építőipar növekedéséhez, az elkészült lakások számát 16,9\%-kal sikerült növelni. Ennek következményeként 1953 derekán a nem önálló foglalkoztatottak 10\%-a az építőiparban dolgozott. A külkereskedelmi mérleg egyenlegét is rövid idő alatt sikerült javítani: 1949-ben még 3 milliárd márkányi deficitet mutatott, 1951-ben ez az összeg már csak 149 milliós mínuszban volt, a következő évben pedig már jelentős szufficittel, 705,9 millió márkával zárt. (Erhardt, 1957, 1990, p. 49.)

A német gazdasági csoda kifejezés nem véletlen. Mialatt a gazdaságstratégiai tervezők az 1952-re befejeződött Marshall-segélyt hosszú távra szóló stratégiaalkotásra is használták, olyan makroadatokkal szembesültek, amelyeket nem mertek tervezni korábban. A 106 millió dolláros segélyt követően további 98,6 millió dollárt biztosított a Német Szövetségi Köztársaságnak, e kettő mellett az új gazdaságstratégiai tervezés azonban nem várt pozitív fordulatot hozott a gazdaságban. Míg az ipari termelést az 1936-os szint 110\%-ában állapították meg 1952 és '53 fordulójára, a tényleges adatok 145,5\%-ot mutattak. Ugyanerre az évre az 1936-os életszínvonalnál 20\%-kal vártak kevesebbet, de tévedtek: a nyugatnémet polgárok az egyötödnyi veszteség helyett már eddigre 7,68\%-os növekedést realizáltak. (Erhardt, 1957, 1990.)

A nagyfokú gazdasági növekedés az emberséges társadalom képével együtt épült. Az ordoliberalizmus képviselői közt akadt valaki, aki a „társadalom gyógyítását” tüzte ki célul: az orvos felmenőkkel rendelkező Wilhelm Röpke. Nem pusztán a gazdaság olyan irányú megváltoztatását dolgozta ki, melyben az egyenlő méltóság elvét kell szolgálnia a szabályrendszernek, de olyan - egyébként teljesítmény szempontjából sem elhanyagolható - tényezőkkel is foglalkozott, mint hogy az embernek időnként szüksége van arra, hogy a természetben járjon, foglalatoskodjon kerti munkával, és fejlődjön egyéb téren is. (J. Horváth, 2000.)

„Az pedig, hogy a gazdaságpolitikát igazitsuk az emberhez és ne megfordítva, egyenesen erkölcsi és emberiességböl következö parancs.” (Röpke in J. Horváth, 2000. 
p. 18.) Röpke Goethe szavaival élt, amikor megfogalmazta, a „régi igazhoz” kell visszatérni. Úgy véli: az ember nem tud „vallási vákuumban” létezni. (Röpke in J. Horváth, 2000. p. 21.) A vallás megtartásán túl a fogyasztás kultúrájának meghaladása mellett is érvel. Állítása szerint az ember nem tud hosszú távon vallás nélkül, kizárólag „valláspótlékokkal” élni, mint a sportfogadások, randalírozás, bűnözés, elemi ösztönök kiélése, újabb televíziók vásárlása vagy kéjutazások.

A fentiekben kifejtett ordoliberális (vagy újliberális) elvek, valamint a neoliberalizmus merőben eltérnek egymástól. Míg elöbbiek szem előtt tartják, hogy a piac önmagától humánus értékeket nem szolgál, utóbbiak úgy vélik, hogy a jólét, a piaci szabadságjogok kiterjesztésével mindenkihez eljut, aki kész érte aktívan tenni. Nem számol egy fontos tényezővel, az esélyek egyenlőtlenségével, és azzal sem, hogy vannak helyzetek, amikor egy ember nem tehet saját sorsának megváltozásáról (mint egy tartós rokkantságot eredményező baleset, vagy egy betegen született gyermek ápolása), és így nem tud aktív részese lenni a piaci folyamatoknak.

Ugyan a neoliberalizmus és az ordoliberalizmus kiindulópontja ugyanaz volt, miszerint a gazdaságot szervezni kell, az emberképük eltért egymástól, ez pedig - az egymástól eltérő társadalomszervezési ajánlatokon keresztül -, egymástól eltérő szerkezetü társadalmakat hozott létre. Mialatt a neoliberális gazdaságpolitikát választó társadalmakban nőttek a társadalmi egyenlőtlenségek, az ordoliberalizmus útját járó Nyugat-Németországban elmozdultak a társadalmi igazságosság felé.

A piaci értelemben vett szabadság a neoliberális gazdaságpolitikában erős volt, azonban nem jelent meg a társadalomszervezői szemléletben az a motiváció, amit az ordoliberális társadalomfilozófusok elsődlegesnek tekintettek: az egyenlő méltóság elve. Ez csak ott érvényesülhet, ahol az esélyegyenlőséget állami eszközök garantálják, és ahol nem történhet meg, hogy bizonyos társadalmi csoportok, jövedelmi helyzetükből eredően, alapvető szabadságjogaikat sem tudják gyakorolni. Wilhelm Röpke számára a közgazdaságtudomány sokkal inkább társadalomtudomány volt. (J. Horváth, 2000.) Aszerint közelítette meg a határhaszon fogalmát, hogy az emberek mit éreznek bizonyos javak fogyasztásánál. Foglalkozott Engel törvényével, és azzal, hogy az alacsony jövedelmü társadalmi rétegek fogyasztását mi határozza meg. Mai fogalmi keretek közt Ludwig Erhardt a versenypolitika fogalmát használná, élesen szembefordulva a hitleri Németország gazdasági rendszerével, amelyben a megtermelt javakat fogyasztották az emberek. Ennek vet véget a II. világháború utáni 
német gazdasági irányváltás, és a fogyasztóra helyezi a hangsúlyt, valódi piacgazdaság felállítását tüzi ki célul, és el is éri azt.

Mialatt Ludwig Erhardt a gazdaságstratégiai tervezés eszközeivel látott neki újragondolni a társadalomszervezést, ordoliberális társa az emberi közösségek legkisebb egységeit is figyelembe vette. Nem állítható, hogy előbbi makro-, míg utóbbi mikroökonómus volt, de a fogyasztó értékválasztásával, a faluközösségekkel, a kistermelők helyzetével, sőt, az ember építő szabadidős tevékenységeivel is foglalkozott.

Wilhelm Röpke „az emberiességet tüzte ki a gazdasági és társadalmi rendszer céljául”. (J. Horváth, 2000. p. 6. - fordítás Alexander Rüstow Rede und Antwort/1963/ Hat der Westen eine Idee? címü müvéből) A „gazdasági humanizmus” képviselöje volt, aki elöre látta a háború után kialakulóban lévő jóléti államból következő problémákat is. Nem pusztán az emberek felemelése volt a célja, hanem a mindenfajta parancsuralmi rendszerrel való szembehelyezkedés. Nem véletlen, hogy még az 1956os magyar forradalmat méltató írásában is felveti a Nyugat felelösségét, és azt a kötelességet, hogy be kell fejezni, amit a magyarok hősiesen megkezdtek Budapesten: véget kell vetni a szovjetek szocialista rendszerének és keleti blokkban fenntartott diktatúrájának.

Úgy véli, a természet jóra ösztönöz minket, a természet közelsége pedig elengedhetetlen Isten közelségének megéléséhez. Ebben Röpkének kétségtelenül igaza van, azonban a természetet az ember évezredek óta alakította, szükség is van az alakítására, különösen a IV. ipari forradalom küszöbén, amikor a társadalomszervezőnek abban is felelőssége van, hogy a természet erőivel és erőforrásaival hogyan gazdálkodunk. A klasszikus értelemben vett természeti állapothoz való visszatérés ezen a ponton már lehetetlen, az eddig bekövetkezett károk mellett is képessé kell válni a Föld megmaradt élővilágának megőrzésére.

A huszadik század közepén - a jelenlegi helyzethez hasonlóan - a korábbi időszakokban elkövetett hibák által teremtett kihívásokra reagáltak a társadalom szervezői. A Harmadik Birodalom embertelenségére válaszul született meg az emberség társadalmának közgazdaságtudományi, társadalomtudományi és szellemi kerete, amely alapvető építőelemként tekint az erkölcsre is - szerinte az üzleti szellemet is bizonyos erkölcsi tartás szabályozza. Ezzel a német liberális filozófia visszatért a kanti hagyományokhoz is. Röpke elméletében világosan fogalmaz a gazdasági, társadalmi és politikai rend kialakítását illetően: ,a szabad piacgazdaság 
az egyetlen olyan rend, amely az ember szabadságával, a szabadságot biztositó állami és társadalmi renddel és a jog uralmával összhangban áll” (J. Horváth, 2000. p. 17.) A Röpke által felvázolt nagy intézményrendszerek részét képezi az önkormányzatiság és a szubszidiaritás elve is (bár ő ezt a kifejezést annak idején még nem használta). A valódi polgári beállítottság, a magántulajdon tisztelete, a magántulajdon megszerzésének értékelése is szerepet kap a keret közt. Kimondja, hogy a piac érték, és hogy az emberek „szabad, spontán együttmüködésének engedik át” a gazdasági rendet, amelyet „a szabad rend tartóoszlopa”-ként számontartott magántulajdon őriz. „Az pedig, hogy a gazdaságpolitikát igazitsuk az emberhez és ne megfordítva, egyenesen erkölcsi és az emberiességböl következö parancs.” (J. Horváth, 2000. p. 18.) A versenyszabályozás terén a „keretpolitika” elveit követi, és a piackonform állami beavatkozásokat tartja elöremutatónak, szemben a nem piackonform intervenciókkal. Előbbi azt jelenti, hogy a verseny erősítése érdekében avatkozik be az állam, míg utóbbi a verseny ellen - vagyis a Röpke által fontosnak tartott teljesítmény-elv - ellen hat. A teljesítmény-elv abból a szempontból is fontos, hogy a klasszikus liberális hagyományoknak megfelelően, a monopóliumok ellen is felemeli a szavát, amely nem pusztán piaci hatékonyságromboló hatással rendelkezik, de a teljesítményelvet is nélkülözi. A monopóliumok ügyében nem csak a szabályozás, vagy romboló hatásuknak mérséklése a célja, hanem azok teljes megszüntetése.

A keretrendszer tartalmazta a verseny szociális hátterének meghatározását is. Azért fontos erről beszélni, mert a „gazdasági humanizmus” értékeinek megfelelően szükség volt még egy tartópillérre, amely a társadalmat szervezi, és amely előremozdítja a piaci folyamatokat. Röpke a gyengék és elesettek mellett érvel, és az ordoliberalizmus többi képviselöjével közösen olyan rendszert hozott létre, amelyben a gazdaság produktivitásához hozzáadni képtelen polgárokról gondoskodik a közösség. A kis- és középvállalatok fejlődését szolgáló gazdaságstratégiai tervezéssel egyúttal a német gazdaság hosszú távú rugalmasságát is előkészítette. Társadalmi víziójának eszményképeként egy olyan falut nevezett meg, amely fölött egy kastély őrködik.

A korábbi liberális gondolkodóknak felrója, hogy „,a piacgazdaságot önmagában nyugvó és automatikusan lezajló folyamatnak tekintették. Nem vették észre, hogy a piacgazdaság a társadalmi életnek csak egy szük tartománya”. (J. Horváth, 2000. p. 71.) A „kapitalisták” - ahogyan Röpke nevezi őket - nem akarták észrevenni, hogy a gazdaság cselekvő alanyai hús-vér emberek, ,gondolatokkal, érzésekkel, akik az igazság, tisztesség, segitökészség, közösségi szellem, béke, rendesen elvégzett munka, 
a szépség és a természet békéje iránt érzékkel bírnak”. (J. Horváth, 2000. p. 71-72.) A gazdaságnak pedig azért van szüksége keretrendszerre, hogy e polgárok méltóságát, és a piacgazdasági szerepük betöltésére alkalmas környezetet biztosítsa.

„A piacgazdasági mag individualisztikus elvét a keret szociális és emberségességi elvének kell kiegyensúlyoznia, ha azt akarjuk, hogy modern társadalmunkban mindkettö fennmaradjon, ugyanakkor az eltömegesedés és proletarizálódás halálos veszedelme se fenyegessen." (J. Horváth, 2000. p. 72.) Röpke hivatkozik Benjamin Constantra, aki szerint a piacnak, az államnak a „maga területén kívül ne legyen hatalma, a maga területén se túlságosan nagy". (J. Horváth, 2000. p. 73.) A piacgazdaságot szerinte csak olyan társadalompolitikával együtt lehet fenntartani, ami azt támogatja. A szakszervezetek elengedhetetlen szerepe, a lakosság éppen elégséges szintű takarékosságra való hajlama, a megtakarításoknak a beruházásokat nemzetgazdasági szinten meghaladó volta, a monetáris- és fiskálispolitikai fegyelem, a teljes foglalkoztatásért és a kihasználatlan kapacitásoknak a gazdaság szolgálatába állításáért tett erőfeszítések mind részét képezik az általa felvázolt ajánlatnak. (J. Horváth, 2000.)

A demokratikus felhatalmazás kihasználásának elutasítása, az elesettekért tett szolgálat, a gazdaság emberarcúsága evidencia volt Röpke számára. „A tömegekre kiterjedö államilag szervezett gondoskodás nem egyéb, mint müláb, amit a proletarizálódás által megnyomoritott társadalomnak készítenek." (J. Horváth, 2000. p. 93.) Ludwig Erhard „Jólétet mindenkinek” jelszava mellé Wilhelm Röpke lényegében felzárkóztatta az üzenetet: „méltóságot mindenkinek”. Nemzetközi gazdasági elméleteivel, a fejlődő világ országainak segítségével - és annak hátterével - mintha megelőzte volna a globális partnerség korát. Kimondta, hogy a harmadik világ országainak felszabadulását fejlődésük hozhatja el, és érvelt amellett, hogy a szocialista rendszerbe való fordulásuk csak szegénységüket termeli újra. (J. Horváth, 2000.)

Nemzetgazdasági téren egy gúla-alakú közösséget szeretett volna kialakítani, az eltömegesedés és az atomizáció folyamataival szemben foglalt állást, háromdimenziós közösségekben gondolkodott, a társadalom szilárd összetartásában hitt, melynek alapját a családban látta. (J. Horváth, 2000. p. 111.) Felvetette a kaotikus kapcsolatszegénységet, és a nemzedékek iránti érzék elvesztését mint problémát. Szerves egészként kezelte a társadalmat, amely közösségként tekint önmagára. A 
globális világ lakosságának stabilizálását kulcskérdésnek tekintette a „társadalom gyógyulása" szempontjából.

A liberális teoretikusok és gyakorlati megvalósítók felelősségéről és feladatáról elmondta, hogy büszkén kell vállalni a liberális gondolatot - csakúgy, mint önmagunk liberalizmusát. Látta a „liberalizmusra ragadt sár” problémáját, és azt a kötelességet is, amelyben ezt a sarat le kell mosni. Úgy vélte, ,, a liberalizmus halála a jog, a béke és az igazság halálát jelentené". (J. Horváth, p. 130-131.) Felvetette, hogy a társadalom válsága vajon a liberalizmus válságában keresendő-e. A liberalizmusra humanista, perszonalista és tekintélyellenes eszmerendszerként gondol, amely képes megőrizni a Nyugatot a megmerevedéstől, „állandóan ható, mozgató erőként”. (J. Horváth, 2000. p. 135.) Röpke szerint nem véletlen, hogy a szélsőjobboldali és a szélsőbaloldali totalitárius rendszerek is a liberalizmusban találták meg saját ellentétpárjukat, és kiáltották ki ezt az ideológiát ellenségképnek.

\subsection{A klasszikus liberális elvek gyakorlati megvalósulása és az ehhez vezető lehetséges út}

A klasszikus liberalizmus képviselői nem a piacra értették az állami beavatkozás tilalmának axiómáját, hanem az emberek magánéletébe, magánszerződéseibe, jogainak érvényesülésébe. Szigorúan véve a jogállami normák keretének felvázolása is beavatkozás - emiatt anarchiáról beszélünk -, de ez az a szabályozás, amely elvezethet a polgárok jogainak és méltóságának egyenlőségéhez. A klasszikus liberalizmus korszakában az emberi méltóság kérdésköre nem ezzel a szókapcsolattal jelenik meg, de amikor Adam Smith vagy John Locke a nyomor felszámolásáról vagy a tömegek kilátástalansága elleni fellépésről beszél, voltaképpen az esélyegyenlőség és a munkavállalói érdekképviselet alapjait fekteti le.

A XIX. századi liberalizmus is alapvetően az egyéni és a kollektív szabadságjogok kiterjesztéséről szólt, ugyanakkor a piac - ahol már akkor is müködött monopóliumokat, kartelleket, gazdasági erejüket politikai befolyásra is használni képes nagyvállalkozókat, valamint családjukat és önmagukat nagyon szerényen ellátni képes munkavállalókat eredményezett. A húszas évek Németországának társadalma az I. világháborút követően ennél a képnél is drasztikusabb. (Ritschl, 2012.) ${ }^{12}$

\footnotetext{
${ }^{12}$ http://eprints.Ise.ac.uk/44335/1/WP163.pdf
} 


\subsection{Liberális állam- és társadalomszervezési alapok az ordoliberálisok elképzelése szerint}

A hatalmi ágak szétválasztásának elve és a társadalmi párbeszéd fontos volt már a XIX. században is. Az állam és az egyház szétválasztásáért is küzdő liberálisok több célt tűztek zászlajukra, amikor az államszervezéssel foglalkoztak. Laski azt mondja: a köztisztviselők pártfüggetlenségét, az erőszakszervezetek tagjainak politikai oldaltól és politikai pártoktól való függetlenségét, a közszolgáltatásokat biztosító iparágakban a munkavállalók jogait, különösen a sztrájkhoz való jogot biztosítani kell, mert a közösség számára nem előnyös, ha az embereknek rosszak a munkakörülményeik. „, $A$ kormánynak véleményem szerint nem áll jogában betiltani a társulásokat, amelyeknek csak a nézetei felforgatóak. " (Laski in Ludassy, p. 54-55.) Harold Laski a XIX. század végén született brit közgazdász és politikatudós, a fenti idézetből is jól látszik, milyen elkötelezett híve volt a pluralizmusnak. Bár a marxizmus kritikusa volt, a Munkáspárt elnöki pozícióját töltötte be, a liberalizmusra pedig a „nyugati civilizáció kiemelkedő doktrinája”-ként tekintett (Greenleaf, 1983. p. 18.).

Ugyan R. Muir (1923) úgy fogalmaz, „mindig sajátja volt a Liberális pártnak, hogy fokozott kételkedéssel kövessen minden, állam általi beavatkozási kísérletet a gazdaságba, mely egyben a szabadság megsemmisitését jelenti.” (R. Muir, 1923. p. 99. in Greenleaf, 1983. p. 30.), e megállapítás a XX. századra törésvonalat hozott a liberálisok számára. A XX. században liberálisok egy csoportja úgy gondolta, a piac mindenhatóságát hirdetni nem jó, mert éppen a széles tömegek nyomora világított rá: a szabályozatlan piac gyakorlatilag jogokat vitat el millióktól. Jogi és államszervezeti tényező, hogy a klasszikus liberalizmus a köztársasági hagyományt szolgálta a XIX. században, a XX. században a jogállami normák váltak fontossá, ezeket kell szolgálni, és a liberális eszmerendszernek bírnia kellett (volna) a képességet, hogy az elvárások szerint változzon.

A liberalizmus következő meghatározó eszmetörténeti korszakát megteremtő Lippmann-konferencián az előbbi tényező emiatt robbantott ki nagy vitát a teoretikusok közt: vajon az eszmerendszer válságát a klasszikus liberális elvekhez mindenáron való ragaszkodás, vagy ezek végletes elárulása okozza. (Dardot-Laval, 2013.) 1938-ban járunk, a nagy gazdasági világválság évtizedének végén, mielőtt a III. Birodalom lerohanta volna Lengyelországot, ezzel végérvényesen átalakítva az egész világot, és kötelezve minden gondolkodót arra, hogy választ adjon a kérdésre: mi 
történik egy világban, amikor az élethez való jogát széles tömegeknek vitatják el rendszerszinten, egész Európában.

Ezeket a borzalmakat követően jelennek meg az ordoliberálisok, a II. világháború utáni Nyugat-Németországban, és igyekeznek elősegíteni a társadalom gyógyulását (mint Wilhelm Röpke), valamint olyan költségvetési politikát folytatni (ami Ludwig Erhard gazdaságpolitikájában tetten érhető), amely a piaci folyamatok a hadigazdaságot és fasiszta diktatúrát követő újjáélesztése (Dardot-Laval, 2013.) az emberi méltóság és a piaci folyamatokba bekapcsolódók jogainak lefektetésével és garanciáival kezdődik.

Az ordoliberalizmus nyugatnémet képviselői azonban nem állnak meg itt. Ugyan a gazdaságstratégiai tervező a teljes foglalkoztatottságot - mint az erőforrások maximális kihasználását (Erhard, 1957.) - célként tüzi ki, tisztában van azzal, hogy az idősek és a betegek (vagy akár a kisgyermekes édesanyák) időlegesen vagy végérvényesen kiszorulnak a munkapiacról. Erhard olvasatában azonban meg kell tenni mindent azért, hogy ne sérülhessen senki méltósága azért, mert önállóan nem tud jövedelmet termelni önmaga számára.

Ebben a gondolatban fogható meg az 1938-as liberalizmus-vita lényege. Úgy vélem, mindkét csoportnak volt igazsága a vitában. Azoknak a résztvevőknek is, akik azt képviselték, hogy a klasszikus liberális elvekhez mindenáron való ragaszkodás okozta a liberalizmus válaszképtelenségét a XX. századi kihívásokra, és azoknak is, akik azt állították: a klasszikus liberális elvek elárulása miatt történt mindez. (Dardot-Laval, 2013.) Ez azért történhetett, mert elöbbi csoport a gazdasági folyamatokra koncentrált, a második pedig a társadalomszervezési alapelvekre. Mialatt a gazdaságban a klasszikus liberális alapelvekhez való végletes ragaszkodás dominált, a társadalomszervezés terén elárulták a klasszikus liberalizmust.

A piaci folyamatok szabadjára engedése fontos liberális alapelv. Az emberi méltóság, valamint az egyéni és kollektív szabadságjogok mindenki számára gyakorolhatók kell, hogy legyenek. Ez egy másik liberális alapelv, amiből a liberalizmus képviselői nem engedhetnek. E kettő összeütközni látszik a XIX. századi liberalizmusban, holott teremthető köztük harmónia, amit az ordoliberalizmus meg is talált.

Az ordoliberalizmus abban különbözik a neoliberalizmustól, hogy az emberi méltóság mindenekfölött való mivoltából vezeti le az elveit. Ez érhető tetten az 1949-es német alaptörvényen, amely azóta is hatályos. Első mondata: „az emberi méltóság mindenekfölött való és elidegenithetetlen" (Grundgesetz der Bundesrepublik 
Deutschland, 1949.). Ehhez keresett a társadalomszervező gazdasági intézményrendszert, aminek része volt a piac. Ez azonban arra kötelezte a liberális gondolkodókat és gazdaságstratégiai tervezőket, társadalomszervezőket, hogy rendszerszintü válaszokat adjanak a szegénység és depriváltság problémájára.

Az ordoliberalizmus nem pusztán az emberi méltóság középpontba állítása miatt egyedülálló, hanem azért is, mert az eszmetörténeti korszakok közül ennek az irányzatnak a képviselöi álltak a legközelebb a klasszikus liberális elvek gyakorlatban való megvalósulásához.

Ma olyan kihívások előtt áll a világ, amire - álláspontom szerint - nem lehet az ideológiamentes korszak meghirdetése a válasz. A világ számos régiójában, dimenziójában morális válságát éli a társadalom, a vallási közösségek elgyengülése után az ideológiákban is tömegek csalódtak, logikusnak tünik a tőlük való elfordulás útján járni. Ezek a II. világháború utáni társadalmi kórtünetekhez hasonlatosak. Mivel a társadalom vezetőinek dolga elsősorban a társadalom globális trendekhez való igazodásának segítése, fontos egy olyan értékvilághoz való igazodás, amely kiszámítható, és amelynek alapelvei alapján társadalomfejlesztő és jólétnövelő szándékkal lépnek fel.

Az ordoliberalizmus képviselői leszögezték, hogy a szabadság nem jelent szabadosságot, és azt is, hogy a polgárok felelősségvállalásuk árán teremthetik meg saját szabadságukat. Ahol az ember nem vállal felelősséget, elvész a szabadság. A történelem során sok társadalom veszítette el így a jogait, és mintegy hallgatólagos szerződést kötött az állammal arról, hogy kötelességeket végezzen el helyette.

Amennyiben a jogállam a szabad piacon való tisztességes magatartásra, valamint az egyes piaci szereplők önvédelmi mechanizmusainak kiépítésére alkalmas keretet vázol fel, megvalósul a jól szervezett és szabálykövető társadalom.

A társadalom önvédelmi mechanizmusaira jó példa a fogyasztóvédelem és a munkavállalói érdekképviselet. A gazdaság szereplői szabad emberek, akik szabad elhatározásukból érdekképviseleti szerveket hoztak létre, amiben a tisztességtelen piaci magatartást kiszürik, és vagy megelözik, vagy ha valaki mégis tisztességtelen piaci magatartást tanúsít, büntetik. Többek közt ezt nevezi Bush és Land (2019.) „részvételi piacgazdaságnak”. Jogrendszer kell, amely nem csak a jelen, de a jövő kihívásaira is reflektál.

„A jogállam és a szabadságjogok Nyugaton hosszú és változatos történelmi folyamat eredményei." (J. Horváth, 2000. p. 107.) A XX. század új kihívásai olyan válaszokat 
is kikényszerítettek a liberalizmusból, amelyekre a XIX. században - nem függetlenül saját ellehetetlenülésétől - nem tudott volna releváns ajánlatot tenni. „Minden azon múlik, sikerül-e behatolnunk az eltömegesedés és a proletarizálódás lényegébe. Ha ez sikerül, a gazdasági és társadalmi reform minden kérdését - a nagyváros, az óriásvállalatok, a gyökértelenség, a szegénység, a személyiség elveszitése, az élettől és természettöl történt elidegenedés problémáit - ennek megfelelöen kíméletlenül kell a megoldás felé irányitani.” (J. Horváth, 2000. p. 116.) Az urbanizációs folyamatok új világot teremtettek sok ember számára, akik korábban falusi környezetben vagy kisvárosokban éltek, már több ezer embert foglalkoztató gyárakban dolgoztak. Ez viszont új társadalmi viszonyokat teremtett, felrúgva sok esetben régi kötelékeket. „A társadalmi lelki higiéniának egyik legsürgösebb feladata a jelenkor nagy politikai gyüjtőneveit az idők folyamán könyvröl könyvre, vezércikkröl vezércikkre, beszélgetésről beszélgetésre rárakódott buroktól megtisztitani." (J. Horváth, 2000. p. 127.) Minden eszmerendszer közül „, a liberalizmus járt a legfurcsábban” - mondja Röpke, és hozzáteszi, hogy amennyiben egy fa allegóriáját használjuk a liberalizmus megjelenítésére, amelyből a legújabb hajtás nem tetszik, még nem kell kivágni az egész fát, noha „ezer fejsze dolgozik ezen”. Hosszú évszázadok és generációk öntözték, nevelték ezt a fát. Az ókor szabadságfogalma alapvetően különbözik a felvilágosodás-koritól vagy napjaink szabadságfogalmától, sok transzformáción keresztülment már a szabadság eszméje.

Nem véletlen az sem, hogy a tömeg dühe, valamint az elégedetlen hangok a piacpárti gondolkodókat és politikusokat szemelték ki ellenségként, akiket végső felelősként neveztek meg a társadalmi folyamatok káros hatásai miatt. Egyszerủen a liberalizmus, ha pusztán a piacgazdasági értelemben vett szabadságra koncentrál, elveszíti önmagát. Sőt. Wilhelm Röpke ennél tovább megy, és azt mondja: ,, (...) a gazdasági liberalizmus eszménye, ti. a szabad piacgazdaság egyáltalán nem elsödleges célja a szellemi politikai liberalizmusnak. Értéktözsdékért, kamatokért, szabad devizapiacokért nem érdemes barikádokra hágni. Igenis el lehet képzelni olyan liberális társadalmat, amely lényegében önellátó parasztokból áll.” (Röpke in J. Horváth, 2000. p. 143.)

Ezzel az állítással részben vitatkozom. Mert való igaz, hogy a tőzsdékért és a nagyvállalatokért nem törtek még ki forradalmak, azonban nem elfelejthető, hogy a szabadság felelősségvállalás árán való megváltását leginkább a piaci folyamatokból eredően tanulhatja meg egy polgár. Amikor Adam Smith arról értekezett, hogy a társadalom kereskedőtársadalommá válik, és ez egyúttal morális cél is, azzal 
végeredményben azt mondta: a piaci folyamatokon szocializálódott társadalom jóval több értéket tud teremteni. A polgárosodáshoz szinte elengedhetetlen a kereskedelmi és pénzügyi értelemben vett felelősségvállalás kérdése.

Röpke önellátó parasztjaihoz hozzá kell tenni, hogy a svájci származású gondolkodó minden bizonnyal olyan önellátó parasztokról beszél, akik tulajdonosok voltak, kiskereskedők, emiatt jól ismerik a piacot és a felelősségvállalást. A polgárosodott városi réteg velük szemben viszont nem tud önellátó lenni. A modern állam három testöre, a piacgazdaság, a jogállam és a demokratikus intézményrendszer együtt képes kialakítani egy olyan rendszert, amelyben felelősségvállalásra képes polgárok élhetnek.

Ilyenformán tehát létezhet olyan társadalom - valószínűleg csak elméletben -, amely önellátó falvak gazdálkodóiból és stabil jogállami normáinak, valamint demokratikus intézményrendszerének köszönhetően liberális közösségnek tekinthető, de a gyakorlatban aligha. Ennek belátására Friedrich A. Hayek gondolatát kölcsönözhetjük: „Az egyes egyének gazdasági tevékenységét a piac az árrendszer révén egyezteti össze." (Hayek, 1995. p. 247.)

Segíti a szereplőket a lehető legnagyobb hatékonyság elérésében, legyen szó fogyasztóról vagy a termelőről. „Az árrendszer komplex gazdasági rendszert tesz lehetővé, mert tehermentesíti az egyéneket a gazdasági összefüggések totalitásának ismeretétöl. A gazdasági tevékenységek komplexitása (vagy ahogyan a klasszikus politikai gazdaságtan nyelvén mondanánk: a munkamegosztás) növekedhet anélkül, hogy ez a tevékenységet végzö egyének teljesitöképességét túlterhelné. A piac az árrendszer révén képes arra, hogy hatékonyan hasznositsa a társadalomban az egyéneknél szétszórtan létezö információt." (Gedeon, 2007. p. 4.) Ha pedig ez így van, akkor a piaci folyamatokból tanuló polgárok azok, akiknek a liberális társadalma nem pusztán kettő, de három lábon áll. A jogállamon, a demokrácián, valamint a szabad, de jól szabályozott piacon.

Az ordoliberalizmus egységes volt, de ugyanakkor mutatkoztak benne különböző irányzatok, amelyeken keresztül különböző társadalmi csoportok számára tudott jövőképet kínálni. Érdekes törésvonal alakult ki az ordoliberalizmus képviselői között: amíg Röpke közelebb áll a paraszti társadalomhoz és a falusi hagyományokhoz, addig Ludwig Erhardt egy városi közegből kiindulva fogalmazza meg társadalomképét. Mindkettejükre szükség van, úgy elméletben, mint gyakorlatban. Az ipari fejlődés során elkerülhetetlen az urbanizáció, azonban a derurarizáció folyamata túlterhelheti a 
városokat és környéküket, ráadásul az ember természettől való távolodását is megteremti, ami káros hatással van az emberiségre.

\subsection{A neoliberalizmus két hulláma}

A Lippmann-konferencia jó példája annak, mit hoz a felismerés, hogy egy ideológia és az általa vázolt gazdaságpolitikai ajánlat újragondolásra, megújulásra szorul. Amennyiben közös akarat van az eszmerendszer teoretikusai között arra nézve, hogy új alapokra helyezzék a gazdaságstratégiai tervezést és a társadalompolitikai ajánlatot, van lehetőség közös definíciókban és irányvonalakban megegyezni. Ez a neoliberalizmus '70-es években bekövetkezett fordulata után elmaradt. Ahogyan Knobloch (1996.) írja: az eredményeknek és a hatásoknak vita tárgyát kell képezniük. Abban, hogy a neoliberalizmus fölött el tudott járni az idő, nagy szerepet játszott az időről időre kívánatos viták elmaradása.

1979-ben az Egyesült Államok jegybankja drámai változtatást eszközölt a monetáris politikában. Harcot hirdetett az infláció ellen, és lényegtelennek tekintette az antiinflációs politika sikerességének árát - ez különösen a munkanélküliségre vonatkozott. Ebben az évben választották miniszterelnökké az Atlanti óceán túlpartján Margaret Thatchert, azzal a megbízatással, hogy vessen véget az inflációs stagnálásnak. Nem sokkal később, 1980-ban Ronald Reagan foglalta el az Egyesült Államok elnöki székét, azzal a motivációval, hogy revitalizálja az USA gazdaságát. (Harvey, 2005.)

A neoliberalizmus és a neokonzervativizmus szegényekkel és elesettekkel szemben követett álláspontja a '70-es, '80-as években széles tömegek számára vált népszerüvé, hiszen szembefordult a jóléti állam túlzott, időnként indokolatlan egyenlőségközpontúságával, azonban egy ponton ez már veszélyeztette az állam stabilitását.

Az eszmerendszer mind a két elemét átfedő elméleti keret a piaci szabadság támogatása és az állami eszközök leépítése volt. A neokonzervativizmus és a neoliberalizmus részben másként müködött Nyugaton, mint a mi térségünkben. A Kelet-Közép-Európában lezajlott rendszerváltásnak köszönhetően ebben a régióban kifejezetten ez az ideológia volt a modernitás, a társadalomfejlődés következő lépcsőfokának elhozója, melyben az egyéni és kollektív szabadság mindenki számára elérhetővé válik.

Frank Nullmeier szerint a liberalizmus pozitívuma, hogy középpontba helyezte a szabadságot, és evidenciává tette az egyenlőséget. A neoliberalizmus azonban arra 
kényszeríti a társadalom tagjait, hogy viselkedésük ,piackompatibilis” legyen, s egyúttal olyan világot teremt, hogy a különböző jövedelmü társadalmi csoportok különböző mértékben élhetnek szabadságukkal. Az egyenlő szabadság biztosításához éppen ezért nem elég pusztán a piac. Nullmeier neoliberalizmus-kritikáját ezekkel az állításokkal támasztja alá: a szociális igazságosság és a szabadság nem áll egymással szemben, sőt, értelmezésében a szociális igazságosság a döntő lépés egy olyan társadalom felé, amelyben minden egyén szabad és autonóm állampolgár lehet. (Nullmeier, 2010.)

Noha a neoliberalizmus tiszta formájában leginkább csak a Reagan-Thatcher korszakban létezett, az Atlanti-óceán két partján és Kelet-Közép-Európában sosem valósult meg, mégis az eszmerendszer legutóbbi eszmetörténeti korszakában ismerte meg a régió a liberalizmust, annak minden akkori tökéletlenségével. Az eszmerendszer haladt az újabb válság felé, amelynek egyik jele az elmúlt fél évtized során a liberális pártok térvesztése.

A neoliberalizmus - amely a konkrét politikai gyakorlatban tagadta, hogy ő maga ideológia volna, gyakorlati megvalósítói pedig megtestesült észszerüségként definiálták -, mégiscsak észszerütlen világot teremtett. Olyan gépezetet épített ki a világpiacon - így az Európai Gazdasági Közösség, később pedig az EU piacán is -, amely amellett, hogy nem volt képes sem előrejelezni, sem megakadályozni, sem kezelni a 2008 III. negyedévében kezdődő világgazdasági válságot, emellett nem sarkallt felelősségvállalásra. A neoliberalizmussal együtt épülő neokonzervativizmus kimondta: a jólétben élö, saját életét megoldani képes ember erkölcsi fölényben van azzal az emberrel szemben, aki munkanélküli, nincstelen, vagy szélsőséges esetben nincs fedél a feje fölött. Az osztrák-amerikai iskola piacszervezési ajánlata végül más képet mutatott, mint az eredeti elképzelés.

Volt a neoliberalizmus korszakával azonban egy probléma: „> $>$ a valóban létező neoliberalizmus < <épp olyan távol esik a Mont Pélerin Társaság és a chicagói iskola társadalmi ideáljaitól - vagyis az egyéni szabadság felvirágzását a szabad és méltányos versenyt és piaci fair play szabályait betartó minimális állam által elömozdító társadalomtól -, amilyen távol a szovjet hétköznapok estek a XIX. század szocialista utópiáitól." (Kapelner, 2019. p. 95.)

A társadalmi különbségeket növelő neoliberalizmus nem kezelte a piaci folyamatokból kimaradó, kevésbé szerencsés társadalmi csoportok kihívását. A neoliberálisok egy 
sok tekintetben szolidaritáshiányos, szélsőségesen individualista, közösségi felelősségvállalást nélkülöző társadalmat szerveztek. (Dardot-Laval, 2013.)

Az „antihumanizmus elvi szintre emelése”, az „elitizmus, a részvételi demokrácia nélkülözése”, az állam piaccal szembeni elsődlegességének tagadása”, a „cselédkapitalizmus felelevenitése”, „a haladás, a holizmus, és a boldogság elérhetöségének tagadása" (Gervai-Trautmann, 2013.) mind jellemezték. A neoliberalizmus ezen felül „nem tudott arról, hogy az állam müködésének nem csak jogi, bölcseleti törvényei is vannak". (Gervai-Trautmann, 2013.) Gervai és Trautmann a XX. századi amerikai és nyugati politikai gazdaságtan átfogó ismeretének hiányával, valamint részleges ismeretének általános tételével is vádolja a neoliberális gazdaságirányítókat, akiktől távol állt a közjó szolgálatának elősegítése, a közgazdaságtant pedig úgy fogták fel, mint a profitszerzés müvészetét.

\section{A neoliberalizmus két hulláma}

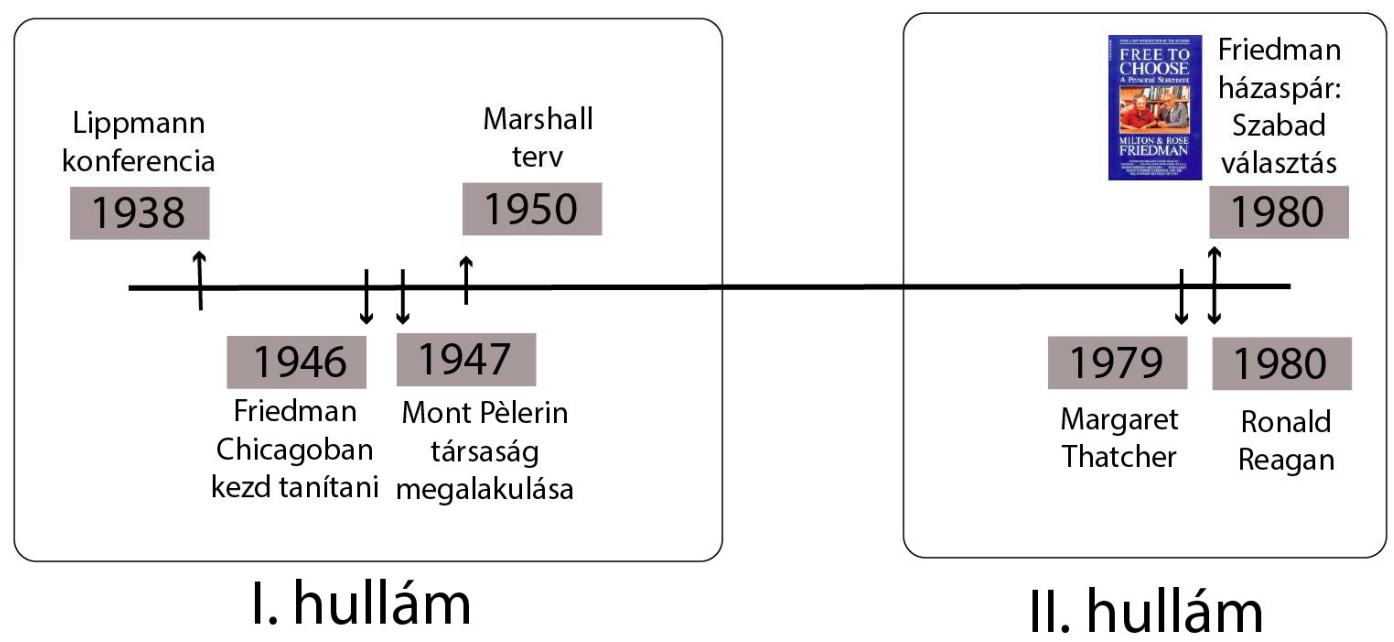

(A számegyenes saját munka)

A második részkorszakban háttérbe szorultak az emberiességi szempontok és a szolidaritás. Az eszmerendszer emberképe - pontosabban eredetileg megalkotott emberképe - nem volt koherens a neoliberalizmus által képviselt gazdaságpolitikai irányvonallal. (Szentes, 2006.) A neoliberális embergyár végül olyan társadalmat teremtett, amelyben már nem a szabadság társadalmát építették, hanem a vállalatok érdekében cselekvő, teljesítménykényszeres menedzserekét. (Dardot-Laval, 2013.) A neoliberalizmust sokszor úgy írják le, mint egy radikális lassez faire tapasztalatot. A piaci liberalizációs politika lerombolta a háború utáni keynesiánus konszenzust és a 
jóléti államot, és egy olyan világot épített helyette, amelyben a biztos jövedelmet nyújtó, nyolcórás munkát sokak számára a temporálisan létező munkahely vagy a részmunkaidő váltotta fel. A jóléti állam lerombolása ugyan egyéni szinten sok esetben okozott drámát, a neoliberális gazdaságpolitika viszont fellendítette a gazdasági növekedést - úgy az USA-ban, mint számos, korábban fejlődő, mezőgazdasági országban, amelyben a gazdasági szerkezetváltást is segítette. (Venugopal, 2015.) Feltehetően éppen utóbbi képessége miatt egy depolitizált technokrata policy agendaként is definiálják.

Amibe az embert figyelembe nem vevő, szigorúan a teljesítményorientált, állami beavatkozást nélkülöző neoliberalizmus belebukott, az nem más, mint hogy a gazdaságirányítási rendszerből adódó szerepek ellentmondanak a liberalizmus emberképének, az emberi méltóság mindenekfölött való tiszteletének és az egyenlő méltóság elvének. A jelenkor liberális teoretikusai azt mondják: az egyenlő méltóság elve az, amely visszatartja a liberálisokat a minimális állam melletti érvelésből. (Kis, 2015.)

Gazdasági, társadalmi, gazdaságstratégiai tervezői problémát okozott, hogy az elmélet és a gyakorlat különböznek egymástól. Piacbarát rendszer felállítása elképzelhetetlen úgy, hogy az államot kivonják a gazdaság irányításából. Hogyan szolgálja az emberi méltóságot és az egyenlö méltóság elvét (Kis, 2015.) a hatalom, amikor a megteremtett piacgazdaság elmélyítette a társadalmi szakadékokat, milliókat hozott méltatlan anyagi helyzetbe, miközben leépítette a szociális hálót, amely képes lett volna kezelni a kialakult társadalmi szakadékot, és fékezni annak elmélyülését? (Dardot-Laval, 2013.)

Ezt a folyamatot némileg enyhítette a szociáldemokrata harmadik út, amely lényegében a liberalizmus alkalmazása volt a szociáldemokráciára. A harmadik út úgy foglalható össze, hogy liberális gazdaságpolitikai és társadalompolitikai keretrendszer, ötvözve a gondolattal, hogy az elesetteken az államnak kötelessége segíteni.

„A neoliberalizmus nincs összhangban a közgazdaságtan liberális hagyományával”. (Szentes, 2006.) A neoliberalizmus figyelmen kívül hagyta azt az elemet, amelyet a klasszikus liberalizmus képviselőitől kezdve három és fél évszázadon át egyetlen liberális teoretikus sem, ez pedig nem más, mint az állam szerepe a piaci tökéletlenségek és társadalmi igazságtalanságok kezelésében.

Kis János (2014) arról ír, hogy a minimális állam melletti robosztus érv elbukik, ha az egyenlő méltóság és az esélyegyenlőség elvének tesztjén kell átmennie. Szentes Tamás 
is úgy vélekedik, hogy a XXI. században nem az állam „mérete” a kritikus kérdés, hanem az, hogy az állam hatékony és demokratikus legyen. Ez a kritérium a good governance elvével rokon, amely kimondja, hogy az államnak rajta kell tartania a gazdaságon a szemét, és mindig az aktuális társadalmi igények szerint korrigálni a piaci tökéletlenségeket. (Dardot-Laval, 2013.)

A gazdasági liberalizmus eredeti értelmezésében ugyanis a piac mindenekfölött való mivolta egyáltalán nem volt annyira egyértelmü, mint amennyire a neoliberálisok előtérbe helyezték a piaci spontaneitást. Úgy tettek, mintha az állami beavatkozás valamifajta mindent felperzselő tüz volna, amely kiégeti a piac által teremtett elosztómechanizmusokat, és kárt tesz bennük. Klasszikus liberális kollégáik ugyanakkor az egyén szabadságából nem az állam piacról való leválasztására következtettek, ők az egyéni szabadság védelmében az állami önkénytöl óvtak.

A neoliberálisokkal ellentétben a klasszikusok nem tagadták a társadalom közös érdekeinek elsőbbségét az egyéni érdekekkel és a piaccal szemben. (Szentes, 2006.) Szemben az állami beavatkozásmentes piacpárti politikával, az ordoliberálisok értelmezésében az állam kitöltötte a rendezőfunkciót (Knobloch, 1996.), és ezzel egy rendezett körülmények közt zajló piacgazdaságnak teremtett pályát.

Míg a német iskola állami beavatkozáson - pontosabban a rendező szerepét felvállaló államon - alapszik, addig Hayek és Mises úgy vélték, az állami beavatkozás önmagát erösítő folyamat, amely szükségképpen totalitárius diktatúrához és kollektivizmushoz vezet. (Dardot-Laval, 2013. p. 160-170.) „A gazdasági szabadság nélkülözhetetlen feltétele minden más szabadságnak, a szabad vállalkozás szükséges feltétele és egyúttal következménye a személyes szabadságnak." (Hayek, 1967. p. 229.) Noha a neoliberalizmus bizonyos elemei a második világháború előtt születtek, fentiek azért is fontosak, mert a totális háború után a szabad világ számára világossá vált, hogy a szabadság fogalma újragondolásra szorul, hiszen nem koherens - és morálisan sem igazolható - szabadságfogalom az, ahol egy társadalmi csoport saját szabadságát azon keresztül kívánja kiterjeszteni, hogy másokét elvitatja.

A mindenki számára mást jelentő szabadság mindenki számára mást jelentő liberalizmust eredményezett. Az amerikaiak állnak legközelebb a neoliberalizmus gondolatiságához és a mély hithez, hogy az ember azzá válhat, akit megálmodik. A franciák a polgárok jogairól beszélnek, és a köztársaság eszméjét helyezik előtérbe. A németek az erkölcsből és a rendből, valamint a mindenkire egyformán vonatkozó 
szabályok betartásából és betartatásából vezetik le a szabadság társadalmát. A keleteurópai válasz változatlanul nincs meg.

A vasfüggönyön inneni régió pedig az Egyesült Államokból érkező receptként érzékelte a liberalizmus 1945-től kiküzdött vívmányait. Olyan csomagként, amely már készen van, holott a régió saját küzdelme még hátravan. Éber Márk Áron (2019) a rendszerváltás előestéjén Budapestre érkező Bockmannt idézve azt írja a reformközgazdászok köréről, akik - nem függetlenül a tengerentúlról érkező cserediákprogramoktól, ösztöndíjaktól és konferenciáktól - rengeteget tanultak a neoliberális gazdaságpolitikáról, és idealizálták is azt: „Professzoraink a Marx Károly Közgazdaságtudományi Egyetemen úgy beszéltek, mint a Reagan-robotok". (Bockman, 2011, VII. in Éber, 2019. p. 128.)

Ugyan nincs okunk kétségbe vonni, hogy Bockmann ilyen tapasztalatokkal gazdagodott a korabeli Budapestre látogatva, az igazsághoz az is hozzátartozik, hogy a neoliberális gazdaságpolitika által teremtett intézményi keretek az akkori nemzetközi gazdasági viszonyainkat merőben meghatározták, alakítottak a világ számos nemzetgazdaságán, és átrajzolták a nemzetközi térképet is. Hazánk 1982-es IMFcsatlakozása, a világban azt megelőző négy évtizedben végbement folyamatok, a Nemzetközi Kereskedelmi Szervezet (ITO), az Általános Vámtarifa és Kereskedelmi Egyezmény (GATT) létrehozása ${ }^{13}$ és nemzetközi kereskedelemben, valamint általános jólétnövelésben betöltött szerepe vitán felül áll.

A kereskedelem liberalizációja, a fejlett világból fejlődők felé meginduló tőkeáramlás, sőt, ennek egy része kifejezetten transzfer formájában való realizálódása jelentősen hozzájárult a fejlődő világ nemzetgazdaságainak és munkapiacainak átalakításához, ezen keresztül pedig a szegénység - legalább egy részének -felszámolásához.

A neoliberalizmus kritikusai méltatlanul feledkeznek meg arról, hogy az eredetileg megalkotott gazdaságpolitikai keretrendszer nem pusztán megcélozta a jólét növekedését, de a világ számos pontján el is érte azt. Amivel nem számolt, pedig a közgazdaságtudomány által ismert tény, hogy léteznek piaci kudarcok, és ezek is kiküszöbölhetők megfelelő szabályozással és jól ütemezett, piackompatibilis állami beavatkozással. Ami a neoliberalizmus történetének és tanulságainak összefoglalását illeti, talán az egyik legfontosabb, hogy a piacnak társadalmi kudarcai is lehetnek, ám

\footnotetext{
${ }^{13}$ http://eta.bibl.u-szeged.hu/940/1/EFOP343 AP6 Vilgazd 4fejezet UdvariB 20181031 olvasolecke.pdf
} 
ezeket megfelelő társadalomszervezési ajánlattal és gazdaságstratégiai tervezéssel korrigálni lehet.

A társadalmi következmények és a jelenlegi kihívásokra adandó válaszok megtalálása éppen a fentiek miatt nem lehetséges a neoliberalizmus keretein belül.

\subsubsection{A neoliberalizmus korszakának lezárulása nem jelenti a liberalizmus végét}

Az eszmerendszer kihívása kettős. Az első dimenziója az, ami miatt a liberalizmus jelenleg a nemzetközi szinten is keresi a helyét, mert legutóbbi megjelenési formája, a neoliberalizmus - együtt fejlődve a neokonzervativizmussal - olyan emberképet és társadalmat eredményezett, amely elvesztette a polgárok bizalmát.

A két eszmerendszer által közösen kreált gondolat, mely szerint a keményen dolgozó polgár meg tudja oldani a saját életét, számos alkalommal kérdőjeleződött meg az ezredfordulót követően. A munkapiaci és társadalmi folyamatok azt eredményezték, hogy akár egy lokális vagy temporális válság is okozhat olyan egyéni helyzeteket, melyekben a szolidaritás eszméje és az állam időleges segítő szándéka megmenthet egy tisztán piaci viszonyok közt ellehetetlenülő munkavállalót vagy kis- és középvállalatot. (Harvey, 2000.)

A vállalatok tisztességtelen piaci magatartása, az információs aszimmetria kihasználása akár ügyfelekkel, akár üzleti partnerekkel szemben természetszerüleg megy szembe a jól szervezett piaci folyamatok elméletével és gyakorlatával. Amennyiben nincs rendező és szervező erő, amely kiszüri a tisztességtelen piaci magatartást, nem valósulhat meg a társadalmi harmónia.

Ha pedig az nincs, a liberális eszmerendszer olyan helyzetbe kerül, mint a XIX. század derekán: a szabad piac és a tökéletes verseny folytonos ismételgetése nem feltételezte róluk, hogy képesek szembesülni a valós világ kihívásaival és társadalmi igazságtalanságaival. Amennyiben a liberalizmus azt a társadalmi üzenetet kívánja közvetíteni, hogy az emberből az válhat, amivé ő maga válni akar, az kötelezi a társadalomszervezőt, hogy az esélyegyenlőség megteremtésére intézményeket hozzon létre. A '70-es évek elejétől hangoztatott társadalomszervezői üzenet nem volt más, mint hogy a vállalati elvárásoknak való megfelelés egyenlő az önmegvalósítással, ami pedig maga a szabadság. Ez az állítás nem más, mint a teljesítmény legmagasabb szintjének kikényszerítése minden egyes pillanatban, avagy a kényszerpályára állított, teljesítménykényszeres menedzserek világa, amelyben mind az egészség, mind az 
emberi kapcsolatok, mind a szabadidő a teljesítmény mögött állnak a közös, társadalmi értékrendben. (Dardot-Laval, 2013.)

A régi világrend töredezése nem véletlen. A neoliberalizmus és a neokonzervativizmus másik legerőteljesebb közös üzenete, hogy az ember az államtól semmire sem számíthat. (Harvey, 2000.) Ez a gondolat csak addig állhatta meg a helyét, amíg a kollektivizmussal szemben határozta meg önmagát, és az új üzeneten keresztül formálta a '80-as évek jelenének emberét.

A kollektivizmust és diktatúrát csak történelemkönyvből ismerö generáció távol került az intézményrendszertől, amelyre a neoliberalizmus és a neokonzervativizmus képviselői forradalmi választ adtak ugyan, de az új generáció így nem érti a modellt, amelyet készen kapott. Az intézményrendszerek bukását, vagy azok reformjának igényét legtöbbször egy ilyen társadalmi folyamat készíti elő.

Az elmúlt évek azt is megmutatták, hogy az individualista polgárok, a társadalmi felelősségvállalásra képtelen vállalkozók ideje lejárt. A pszichiátria több olyan tevékenységet megnevez, amelyek nélkül az ember nem élhet teljes életet, mint a rendszeres testmozgás, nevetés, a lazítás képessége vagy az altruizmus. (Bagdy, 2013.) John Locke is megfogalmazott a felvilágosodás korának embere számára egy olyan életvezetési útmutatást, amely a boldogság elérését szolgálja: Locke az egészséget, a jó kedvet, a tudást, a jócselekedetet, valamint a "túlvilági örök, megfoghatatlan boldogság reményét" tartotta fontosnak, nagy hasonlóságot mutatva a jelenkori tudomány által felvázolt, négy elemből álló egységgel. (Locke, 1693.)

Az elmúlt négyszáz évben a liberalizmus jelentős változásokon, alakváltásokon ment keresztül. Az eszmerendszer útkeresése nem véletlen: a szabadság definíciója folyamatosan változott a modern korban, és ez az ideológia folytonos rekreációját eredményezte.

Az európai liberalizmusnak alapvetően három - fentiekben röviden tárgyalt irányzata alakult ki. Ludwig Erhard ,jólétet mindenkinek” (Erhardt, 1957.) gondolata célravezető eszköz lehetne a jelenben is, annak érdekében, hogy a társadalom nehezebb anyagi körülmények közt élö csoportjai elérjék azt az életszínvonalat, amely már képessé teszi őket az alapvető jogaik gyakorlására. Ezzel a modellel azt is célozza egy társadalomszervező, hogy az emberek életében mérsékelje a szűkös erőforrások teremtette feszültséget, a másik emberhez füződő viszony egyik fontos tényezőjét.

A szabadság eszméjének leple alatt olyan világ épült az 1979-ben kezdődött korszakban, amelyben a szabadságával élni tudó, azt élvezni képes ember éppen hogy 
bezárult egy olyan rendszerbe, amely elvárta a szereplőktől, hogy viselkedésük piackompatibilis legyen, de arra már nem képes, hogy valódi szabadságot nyújtson. A neoliberalizmus nem a szabadság, hanem a teljesítmény társadalmát építette, tette mindezt úgy, hogy közben szüntelenül közvetítette a szabadságról alkotott eszményképet, amelyet maga sem volt képes megvalósítani. (Dardot-Laval, 2013.) Amennyiben a liberalizmus a XXI. században a szabadságjogok érvényesítésére vállalkozik, nagy kihívásokkal kell megküzdenie. A fentiekben vázoltak azt eredményezik, hogy eljutottunk a neoliberalizmus korszakának lezárulásához, azonban az eszmerendszer következő gazdaságstratégiai és társadalomszervezési lépcsőfoka még kérdés.

\section{MI KÖVETKEZIK A NEOLIBERALIZMUS UTÁN?}

E dolgozat állítása az, hogy a szabadság és a humanizmus eszméinek ötvözete adhat jó válaszokat a XXI. századi kihívásokra.

A „neoliberális embergyár” utáni racionalitásfogalom középpontja a közösség. (Dardot-Laval, 2013.) A közösségi gondolkodás az, amely meghozhatja az eszmerendszer számára a megújulás lehetőségét. A bevezetőben ismertetett új racionalitás fogalom nem más, mint az egymásért való felelősségvállalás, amely túlmutat a neoliberalizmus egyéni felelősségvállalásán, és egy magasabb társadalmi fejlődési lépcsőfokot készít elő.

Annak a felismerése, hogy szabadság és felelősségvállalás valójában egy és ugyanaz, létkérdés a liberális eszmerendszer fennmaradása és társadalomszervezési ajánlatának megfogalmazása érdekében. Úgy kerülnek egymással összhangba, ha a közösség tagjai mindkettőt magukénak tudják, és tisztába kerülnek a ténnyel, hogy nem létezik egyik nélkül a másik: kölcsönösen teremtik meg egymást. Az új racionalitás túllép az egyén önmagáért való felelősségvállalásán, és ezzel új értéket ad az egész társadalomnak.

A liberalizmus történetében volt már egy olyan eszmetörténeti korszak, amely ezt megteremtette, és államszervezési kérdéseket is a humanizmus, valamint a szolidaritás szürőjével vizsgáztatott, tette mindezt úgy, hogy a szabadság, a jogállami keretrendszer, a demokratikus intézményrendszer stabilitása, valamint a piacgazdaság működése elsődleges célként lebegett mind a teoretikusok, mind a gyakorlati megvalósítók előtt. Az ordoliberalizmus egy olyan részkorszakot teremtett a XX. századi liberalizmus történetében, amely gazdasági értelemben sosem látott 
fellendülést, társadalmi értelemben jogegyenlőséget és az egyes csoportok közti békét hozta el, a társadalom szerencsétlenül járt tagjai számára pedig kezet nyújtott, és nem hagyta öket elveszni. A következő fejezet ezt a korszakot veti össze a neoliberalizmussal. (Erhardt, 1957.) (J. Horváth, 2000.) (Dardot-Laval, 2013.)

\subsection{Ordoliberalizmus és neoliberalizmus összevetése}

„A civilizáció központi értékei, mint az emberi méltóság és a törekvés, hogy mindenki számára azonos jogokat teremtsenek" (Harvey, 2000. 5. o.) helyes törekvések voltak, de időről időre szükség van az éppen aktuális társadalomszervezési ajánlat felülvizsgálatára. Matthew Arnold szerint, „, a szabadság egy nagyon jó ló, amit nagyon jó hajtani, de csak akkor, ha tudjuk, merre tartunk”. (Harvey, 2000. 6. o.) Talán abban fogható meg a neoliberalizmus egyik legnagyobb hiányossága, hogy a szabad piacot nem eszközként, hanem célként fogta fel, és nem született meg benne a felismerés, hogy ez önmagában még nem egy olyan ajánlat a gazdaságstratégiai tervezők részéről, ami a lehető legtöbbek boldogulását hozná el.

A neoliberalizmus legnagyobb hibája, hogy elmélyítette a társadalmi szakadékokat, és nem volt igazán hatékony abban, hogy revitalizálja a világpiacot. De a 2000-es évek elejéig közel három évtizeden át formálta a globalizációs folyamatokat, azonban azok is hatottak rá. A neoliberalizmussal további probléma volt, hogy a szolidaritás minden formáját támadta. Reagan tanácsadói egy stagnáló, beteg gazdaságra gondolták megoldásul, és a gazdaságstratégiai tervezés átírását összekötötték egy „nagy állam” elleni kampánnyal. A klasszikus liberalizmus önmaga válságát idézte elö. Alaphiba, hogy a társadalom müködési mechanizmusait összekeverte a természeti törvényekkel. Rougier szerint, „a gazdaság politika fölötti primátusába vetett hit” alapján, a liberálisok kettős tévedésben voltak. Abban is tévedtek, hogy a gazdaság ugyanúgy Isten mủve, mint a természet, ezért azt nem szabad bolygatni, meg kell hagyni a saját müködési mechanizmusait, és abban is tévedtek, hogy minden más politikai döntést a gazdasági erők alá kell rendelni. Rougier szerint a liberálisok kettős tévedése az alábbiakban megfogható: „A legjobb törvényhozó az, aki soha nem avatkozik be a gazdasági erők mozgásába, és aki minden morális, szociális és politikai problémát azok alá rendel.” (Dardot-Laval, 2013. p. 168.)

A társadalomszervezés intézményi dimenziója, hogy a gazdasági társaságot éppúgy a jog hozza létre, ahogyan a parlamentet. Jogok és kötelességek egyensúlya müködik mindkettőben. Dardot és Laval szerint az „emberi emancipáció eszményét” a XVIII. 
században elökészítő és végigküzdő liberálisok azonban elkövettek egy nagy hibát, aminek volt jogi és közgazdasági megjelenési formája. (Dardot-Laval, 2013.)

A közgazdaságtudományi tévedés abban állt, hogy a leegyszerüsített modellek mögött valós társadalmi mechanizmusokat láttak. A jogi tévedés pedig abban, hogy az emberek alkotta jogrendszer és a gazdaság a természetből eredeztethetők, így a társadalomszervező és a gazdaságstratégiai tervező hibát követ el, ha beavatkozik folyamataikba - csakhogy ez így nem igaz. A természet törvényeibe valóban nem vagy csak korlátosan - lehet beavatkozni. A gazdasági és társadalmi intézmények azonban más kategóriába esnek. Ember alkotta őket, és magukra hagyva nem tudják biztosítani saját működésük szabályozott stabilitását.

A jogállami normák, a demokratikus intézményrendszer és a piacgazdaság, szemben a természettel, olyan mesterséges intézmények, amelyek időről időre felbukkanó hiányosságait a jogalkotónak kell korrigálnia. Ilyenek a piaci kudarcok, a joghézagok, de azok az esetek is, amikor a tömegdemokráciában a félretájékoztatás, vagy társadalmi csoportok szavazatleadásának ellehetetlenüléséből fakadóan a választás mindössze a fennálló rend megmaradását, nem pedig a társadalom döntéshozók felett gyakorolt kontrollját jelenti.

A XIX. század végére a gazdasági liberalizmus elméleti és gyakorlati képviselői elszakadtak a valós társadalmi folyamatoktól, elvi szinten hangoztatott dogmák alapján próbáltak tájékozódni, és ajánlatot tenni a társadalom felé, azonban ez nem müködött. (Dardot-Laval, 2013.) Ugyanez történt a neoliberalizmussal is, amelynek hajnalán Reagan és Thatcher az Atlanti-óceán két partján a világgazdaság stagnálása elleni fellépés közepette az emberjogi és a politikai liberalizmus elveit háttérbe szorították. (Harvey, 2000.)

„Nem a verseny az, ami megöli a versenyt, hanem sokkal inkább az állam, a morálisan gyenge állam az, ami, miután elhanyagolja a piaci rend biztositásával kapcsolatos kötelezettségeit, hagyja eltorzulni a versenyt, majd hagyja, hogy fosztogató hajlamú lovagok visszaélhessenek jogaikkal és megadják a kegyelemdöfést az eltorzult versenynek.” (Dardot-Laval, 2013. p. 175, Le Colluque Lippmann i. m. 41.) Jogosan vetődik fel a kérdés, hogy az erős liberális államot akkor mi különbözteti meg a kollektivizmustól. „Szó sincs a hatalom erejének csökkentéséröl” (Dardot-Laval, 2013. p. 185.), arról van szó, hogy annak természetét változtatja meg. Az elitek kormányzása azért fontos, mert a társadalomszervezés a jogok és szokásjogok betartatásának irányába kell hasson. Ehhez erős szakértői kormány szükséges, és 
annak szándéka, hogy a gazdasági folyamatokat nem irányítani, hanem szervezni akarják.

„Az erös államot csak egy olyan szakértői elit kormányozhatja, melynek gondolkodásmódja alapvetően ellentétes a tömegek csodaváró és türelmetlen hangulatával: (...) azok, akikre a hatalomgyakorlás felelösségét bizzák (...), olyan embereknek tekintsék magukat, akik gondoskodnak a közérdek részérdekekkel szemben való érvényesüléséröl.” (Dardot-Laval, 2013. p. 185.) Ennek értelmében el kell utasítani a demagógiát, a rövid távú hasznok hosszú távú stratégiákkal és érdekekkel szembeni felülkerekedését, gondoskodni kell arról, hogy az egyének közti verseny közösen lefektetett szabályait mindenki betartsa. Nem pusztán gazdasági, de jogállami és demokratikus intézményrendszeri téren is így van ez. Ennek értelmében „a nép kötelessége, hogy megnevezze, ki az, aki vezetni fogja, és nem az, hogy folyamatosan megmondja, mit kell tenni”. (Dardot-Laval, 2013. p. 186.)

Az ordoliberálisok a fenti problémákon felülemelkedve hirdetik meg a rendet mint politikai feladatot. A ,gazdasági rend” (Wirthschaftsordnung), „a gazdaság rendje” (Ordnung der Wirtschaft) Walter Eucken olvasatában megkülönböztetendők. Elöbbi a gazdaság keretrendszerére utal - vagyis arra, hogy a gazdaságstratégiai tervező milyen keretrendszert vázol fel a gazdaság szereplői számára - utóbbi pedig a versenyen alapuló rend, a Wettbewerbsordnung megfelelője, vagyis az, ahogyan a gazdaság szereplői (úgy a fogyasztók, mint a termelők, üzletfelek, üzlettársak, magánszerződések aláírói) élnek a társadalomszervező által felvázolt keretekkel. Betartják és betartatják annak szabályait. (Dardot-Laval, 2013. VII.)

Walter Eucken az 1945 utáni Németország helyreállítása érdekében felvázolt keretrendszere egybevág azzal a gondolattal, hogy a demokrácia, a jogállam és a piacgazdaság egymástól nem elválasztható intézmények, sőt, bizonyos értelemben kölcsönösen teremtik egymást és kölcsönösen függnek egymástól. Michel Focault szerint „A modern történelem arra is világosan megtanit, ugyanúgy, mint a régebbi korszakok, hogy az állami vagy jogi rend visszahat a gazdasági rend alakulására." (Dardot-Laval, 2013. p. 191.)

Eucken ennél továbbmegy, ő a „rendek interdependenciája” (Interdependenz der Ordnungen) kifejezést használja arra a jelenségre, hogy „,...) az állam segíti a magángazdasági hatalom létrejöttét, majd függővé válik tőle. Így nem igaz, hogy a többi rend egyoldalúan függ a gazdasági rendtöl, hanem a >rendek kölcsönösen 
függenek egymástól<" (Dardot-Laval, 2013. p. 191.) A piaci rend úgy alakulhat ki, ha a többi intézményrendszer „erkölcsi alapokon nyugvó” szabályozást alakít ki.

Eucken, Röpke, Erhardt és társai ebben az időszakban más gondolkodókkal együtt kérdőjelezik meg a szabad piacot, de elméleti keretet egyedül ők adnak ennek az irányzatnak, ezzel felülemelkedve mindenkin, aki a II. világháborút követően a free trade kritikája mellett érvel. Eucken a „Das ordnungspolitische Problem” (1948) címü cikkében kritizálja a klasszikus politikai gazdaságtant, a természetjogi, naturalista felfogást, és világosan állást foglal benne az ember teremtette gazdasági rend fontossága mellett.

„Azt hitték: a természetes rend spontán módon létrejön, és a társadalom testének nincs szüksége az >>étrend szigorú megszabására" (Smith), vagyis a gazdaság a rendteremtés konkrét politikája (Withschafstordnungspolitik) nélkül is virágozhat." (Dardot-Laval, 2013. p. 192.) Az ordoliberálisok állítása szerint a klasszikus liberális közgazdászok és teoretikusok bizalma a gazdaság önmagában való rendteremtési mechanizmusaiban túl nagy volt, ez pedig jelentősen torzította a gazdasági rend irányítását.

Wilhelm Röpke Civitas humana címü cikkében utal is a Lippmann-konferenciára, a „civilizáció mestermüvének” nevezi a piacgazdaságot, melynek építéséhez bölcsesség és pontos tervezés szükségeltetik - csakúgy, ahogy a demokrácia kiépítéséhez. A freiburgi iskola közgazdászai, Franz Böhm és Walter Eucken, valamint a „szociológiai indittatású" ordoliberálisok, Wilhelm Röpke, Alfred Müller-Armack és Alexander Rüstow képviselték. Elöbbiek a jogi és intézményrendszeri keretek lefektetésére fókuszáltak, míg utóbbiak a társadalmi környezetet elemezték, melyben a gazdaságnak léteznie kell. (Dardot-Laval, 2013.) Emiatt kimondható, hogy bár az ordoliberalizmus képe nem egységes, abban mégiscsak egységet találunk, hogy szembefordult a klasszikus politikai gazdaságtan téves illúzióival. A XIX században ezek az illúziók azt eredményezték, hogy a liberális közgazdászok nem voltak képesek releváns válaszokat adni az akkor fennálló világgazdasági és társadalmi rend kihívásaira.

A Harmadik Birodalom embertelen világa után az intézményrendszerek rekonstrukcióján, a gazdasági felemelkedésen és a szociális biztonságon keresztül teremtett újra legitimitást a német állam saját maga számára. Wilhelm Röpke azt mondja, hogy a totalitárius diktatúra a „civilizációs krízis” egyik dimenziója volt, és úgy látja, hogy ,, az az állam legitim, amely aláveti magát a jognak, tiszteletben tartja 
a választási szabadság elvét, természetesen, de ugyanakkor engedelmeskedik a szubszidiaritás elvének is (...)." (Dardot-Laval, 2013. p. 197.)

Röpke egy volt azok közül a közgazdászok közül, akik a közgazdaságtudományt inkább társadalomtudományként fogták fel: a boldogsággal is foglalkozott. Szociológiai hátteret keresett a gazdasági folyamatokban, kimondta azt, hogy az ember akkor tud kiteljesedni és hasznos része lenni a társadalomnak, ha felismeri, hogy mások felé is vannak kötelezettségei, és el is végzi ezeket. Az egyént a valahová („családhoz, faluhoz, városnegyedhez, régióhoz”) való tartozás élménye felelösségtudattal tölti el, és ez segíti ôt a kiteljesedésben.

Az ordoliberálisok mintha megfordítanák József Attila Levegöt! címü müvének utolsó gondolatát, és azt mondanák: „Jöjj el, rend! Te szülj nekem szabadságot!” A társadalomszervezőnek ebben a helyzetben olyan gazdaságstratégiai tervet kellett készítenie, amely más pályára állítja a Német Szövetségi Köztársaság gazdasági növekedését. A fentiekben már láttuk, hogy Ludwig Erhadt és társainak terve teljesült. Az újonnan alakult német állam és demokratikus intézményrendszer elöször is azzal kezdte, hogy az előbbiekben idézett német alaptörvény első gondolata az emberi méltóságé, amit mindenekfölött valónak és elidegeníthetetlennek kell tekinteni. Ez a mondat az egész országot kötelezi, hogy mindennel forduljon szembe 1949-től kezdődően, ami felé a Harmadik Birodalom tíz évvel korábban fordult, és ami mellé széles tömegeket állított. Ehhez viszont szükséges ,versenyelvü rend jogi feltételeinek létrehozása” (...), valamint ,a szabályok betartását elfogulatlanul ellenörzö apparátus" (Dardot-Laval, 2013. p. 201.)

Az ordoliberalizmus fontos eleme ezen felül - és ezzel szembehelyezkedik a szociális piacgazdasággal és a jóléti állammal -, hogy felfogásukban a „mindenki jóléte” csakis a piacgazdaságon keresztül elérhető, sőt, mindenfajta segélyezést a „gazdasági szereplők demoralizálása"-ként aposztrofálnak. (Dardot-Laval, 2013. p. 208.) Azt mondják: „a szabad versenyben született jólét” és „,az általános jólét” egy és ugyanaz. „Az erkölcsi érték a konkurenciaharcban van, és nem a gondoskodó állam védelmében" (Dardot-Laval, 2013. p. 209.) - ez az ordoliberalizmus alapvetése. Hogy a szabályokat úgy kell megalkotni, hogy a tisztességes piaci magatartás legyen irányadó a gazdaság szereplői között. A versenyért megfogalmazott szabályok azok, amelyeknek előremutató hatásuk van. Az állami újraelosztás érdekében és a piaci folyamatok ellen ható szabályozásokat elvetik, sőt, azt állítják: utóbbiakban morálisan 
sérül a társadalom, mert az ilyen rendszerekben ,mindenki a szomszéd zsebében kotorászik". (Erhardt, 1957, p. 164.)

Végezetül, Michael Focault szerint a „társadalom kormányzásáról” kell beszélnünk, nem pedig ,gazdasági kormányzásról”, ahogyan azt a fiziokraták tették. Fontos, hogy ne szociálpolitikáról beszéljünk, hanem társadalompolitikáról (Gesellschaftspolitik), és az is lényeges, hogy „a hatalomgyakorlás tárgya és célja a társadalom, a maga egészében, és semmiképpen sem a magasabb jövedelmüektöl az alacsonyabb jövedelmüek felé áramló transzferekröl van szó, mint a szociálpolitika esetében." (Dardot-Laval, 2013. p. 210.)

Wilhelm Röpke többes célt tüzött ki feladatul. Az elsődleges az volt, hogy „a piacgazdaságot megóvjuk a kollektivizmus halálos mérgétöl”. A második, hogy a „kapitalizmust vita tárgyává tegyük”, mert az elméleti formája eltért attól, ami a gyakorlatban megvalósult, ez pedig zavarokat okozott. Röpke a Civitas humana címü könyvében arról ír, hogy a monopóliumok, és az „állam irracionális túlkapásai” torzították a piacot. A piacgazdaság „meghamisitott és besározott formája” az, amit látunk. A „Felvilágosodás optimista racionalizmusát” kárhoztatja, amiért az nem vette észre, hogy a „társadalmi kötelékek” rendkívül különbözőek, melyek keretében a piac létezik, és ebből adódóan nem számolt azzal, hogy a közgazdaságtudományban használt leegyszerüsített modellek állami irányítás híján piaci kudarcokba fordulnak. A „társadalom meggyógyítására” így Röpke oly módon vállalkozik, hogy „a parancsuralom, a despotizmus és a függöség két típusától, a kollektivizmustól és a monopolkapitalizmustól egyforma távolságot tartó $>>$ harmadik utat $<<, \quad a$ $>>$ konstruktív liberalizmust $<<$ és a $>>$ gazdasági humanizmust $<<$ " (Dardot-Laval, 2013. p. 210.) kívánja létrehozni.

A társadalom meggyógyítása és a gazdaság talpra állítása is sikerült. A Német Szövetségi Köztársaság az '50-es évek elejétől kezdődően csaknem két évtizeden át egy olyan növekedési ütemet tudott magáénak, amiről korábban Ludwig Erhardt sem mert álmodozni. A korábbi becsléseiket már az első évben túlszárnyaló gazdasági teljesítmény, a demokratikus intézményrendszer és a jogállam stabilizálása, valamint a polgárok önszerveződő érdekképviseleti szervezetei egy közel negyven éven át töretlenül gyarapodó és polgárai számára jogegyenlőséget biztosító országot hoztak létre. 


\subsection{Ordoliberalizmus számokban - a német gazdasági csoda}

Az ordoliberalizmus eszmetörténeti bemutatását követően, ez a fejezet Ludwig Erhardt Jólétet mindenkinek (1957) című évtizedösszegző művének tényadatain nyugszik. A Konrad Adenauer kormányában még gazdasági miniszterként tevékenykedő szakember 1963 és 1966 között Németország kancellárja is volt, korábbi kormányföjétől vette át a stafétát, ami azt is jelenti, hogy a németek nem vonták meg politikai közösségétől a bizalmat. E fejezetben lényegében e bizalom hátterét elemzem.

Az ordoliberalizmus képviselői - akik egyébként több különböző eszmerendszert vallottak magukénak - által felépített gazdasági keretrendszerből eredő gazdasági sikerek, valamint a társadalmi-politikai változások az egész országot megváltoztatták, mindössze tíz év leforgása alatt. Ezt követően csaknem egy újabb évtized telt el úgy, hogy a jól lefektetett alapok még mindig bőségesen hozták a nyereséget a német gazdaságnak. A sikerszéria közel két évtized után szakadt meg: a világgazdasági dekonjunktúra elöszele hozta meg a fordulatot. A Német Szövetségi Köztársaság az olajválság éveit követően megszenvedte saját válságát, míg végül a talpra állásra is kész volt. Az újabb gazdasági sikerek egy részét azonban már a rendszerváltást követő szolidaritásra fordították. (A dolgozat a gazdaságtörténet 1990-es évet követő időszakával nem foglalkozik, csak a kész részre osztott Németország nyugati felének gazdaságstratégiai tervezését elemzi.)

Németország rendkívüli veszteségekkel zárta a II. világháborút. A Harmadik Birodalommal való leszámolás minden értelemben megrongálta az országot, úgy infrastrukturálisan, mint gazdaságilag, társadalmilag és politikailag. A német háztartások 20 százalékát teljesen lerombolták. A fejenkénti élelmiszertermelés 1947ben mindössze az 1938-as adatok 51\%-át hozta, a dolgozókorú férfiak jelentős hányadát megölték, másik részük olyan súlyosan megsebesült, hogy átmenetileg vagy sok esetben véglegesen - munkaképtelenné vált. (Henderson, 2018.) ${ }^{14}$

A németek által NS-diktatúrának (Bush-Land, 2009) nevezett rémálomtól minden értelemben eltávolodó, nagyhatalmi törekvéseket elvetö, hadseregét tekintve önkorlátozó ${ }^{15}$ ország úgy vált az Európai Gazdasági Térség hegemónjává, hogy kül-

\footnotetext{
${ }^{14}$ https://www.econlib.org/library/Enc/GermanEconomicMiracle.html

${ }^{15}$ http://phd.lib.uni-corvinus.hu/119/1/keller krisztina.pdf
} 
és biztonságpolitikáját is a „szerény visszahúzódás” jellemezte. (Langguth, 1996. p. 11.)

A Német Szövetségi Köztársaság 1950 és 1959 közt produkált növekedése egyedülálló volt. Évente átlagosan 8 százaléknyi gazdasági növekedést produkáltak, és egyetlen évtized alatt megduplázták a nemzetgazdaság teljesítményét. (Eichengreen-Ritschl, $2008)^{16}$

A német gazdasági csoda több ciklusra osztható. Az első valószínüleg már 1950 előtt elkezdődött, és 1958-ig tartott, nevezhető akár az új gazdasági rend megalapozó fázisának is. A produktivitás és a GDP gyorsan nőtt ezekben az években, a munkanélküliség dinamikusan csökkent, az infláció alacsonyan maradt. A következő ciklust 1959 és 1967 között találjuk, amikor változatlanul gyorsan növekvő produktivitás, gyors GDP-növekedés volt tapasztalható, emellett pedig stabilizálódott a teljes foglalkoztatottság, igaz, az inflációs ráta némiképp már növekedett. (BushLand, 2009. p. 7.)

A harmadik ciklus a már 1967-ben is érezhető krízissel kezdődött, amely a II. világháború óta elöször rengette meg a Német Szövetségi Köztársaság gazdaságát és politikai folyamatait. 1967 és 1975 között még találunk 6 százaléknyi gazdasági növekedést, azonban az 1973-as olajválság Nyugat-Németországban is éreztette a hatását: az NSZK-ba is bekúszott a dekonjunktúra. A háború után először nőtt 3 százalék fölé a munkanélküliségi ráta, a következő időszakban pedig elkezdődött „a tömeges munkanélküliség időszaka”. Az 1976-tól 1982-ig tartó időszakban mutatott némi erősödést a gazdaság, de 1980 és 1983 között az ipar teljesítménye 6 százalékkal szükült. A '80-as évek végére összeszedte magát a gazdaság, újfent 4 és 5 százalék közé hozta a gazdasági növekedést (Bush-Land, 2009. p. 7.), ezt követöen pedig bekövetkezett a német újraegyesítés, ami már alapvetően más kihívásokat tartogatott, és szigorúan véve nehéz a korábbi korszakkal együtt elemezni - ezt a dolgozatban nem is teszem. A fentiek azonban még nem lettek volna elegendőek ahhoz, hogy tömegek jólétéhez és jól-létéhez vezessen.

A Harmadik Birodalom diktatúráját követően kiépült a stabil demokratikus intézményrendszer, valamint a jogállami normák, a polgárok különféle védelme és biztosítási rendszere előkészítette, hogy a részvételi demokrácia mellé felépíthessék a

\footnotetext{
${ }^{16} \mathrm{http}: / /$ www.Ise.ac.uk/Economic-History/Assets/Documents/WorkingPapers/EconomicHistory/2008/WP113.pdf
} 
„részvételi piacgazdaságot” is. (Bush-Land, 2009, p. 22.) Ezalatt a munkavállalói jogok lefektetését értik, és azon törvények jogerőre emelkedését, amelyek a munkavállalókat védik. Balesetbiztosítás, egészségbiztosítás terén is nagyot léptek előre, biztosítva ezzel, hogy a polgárok minden értelemben vett kiszolgáltatottsága csökkenjen. A munka világának humanizálása, új munkaformák bevezetése azt segítette, hogy a gazdasági növekedésböl a lehető legtöbbek a lehető leginkább részesedhessenek. (Bush-Land, 2009, p. 29.) ${ }^{17}$

A rendkívül gyors gazdasági növekedésben szerepet játszott az intézményi keretrendszer, ugyanakkor az egyéni teljesítmény hatékonyságnövekedése is. NyugatNémetország a brit termelékenység 75 százalékáról indult 1950-ben, és 1960-ra utolérte azt. Németország II. világháború alatti növekedése, a piaci erők állami szabályozás alá vétele, a háború utáni munkásmozgalmak és munkavállalói érdekképviselet fejlődése, a katolicizmus és a német konzervativizmus ereje, valamint a hosszú távú növekedési program lefektetése mind hozzájárultak a szociális piacgazdaság kialakulásához. (Eichengreen-Ritschl, 2008)

A Marshall-segély - természetesen - segített az ország talpra állásában, de azt állítani, hogy nélküle elképzelhetetlen lett volna az a gazdasági trendvonal, amit a Német Szövetségi Köztársaság képes volt kialakítani 1950 és 1967 között, nehéz. 1954 októberéig 2 milliárd dollárra rúgott a segély összértéke, azonban még amikor a segély folyósításának csúcsán járt, 1948-ban és 1949-ben, akkor sem érte el az NSZK GDPjének 5 százalékát. Más országok ennél jóval nagyobb segélyből kisebb gazdasági növekedést értek el. (Henderson, 2008.)

A II. világháború utáni nyugat-Németország nem pusztán a gazdaságot, de a társadalmat is „kigyógyította abból a sok szenvedésböl és fájdalomból”, amit a világégés hozott, valamint biztonságosan hozta rendbe az országot, hogy a régió visszatérhessen a stabilitáshoz. Mindarra, amin az NSZK keresztülment az '50-es években, valószínüleg szükség lesz a világban a közeljövőben. (Hodder, 2019.) ${ }^{18}$ Az alábbi két diagram önmagáért beszél. Természetesen kisebb visszaesések, vagy a gazdaság egyes szektoraiban felmerülő szükülések történtek, de alapvetően egy olyan

\footnotetext{
${ }^{17}$ http://www.rla-texte.de/texte/2\%20a\%20SOEB/SOEB\%20Makro\%200kt\%202009-12$01 \% 20$ busch\%20land.pdf

https://pdfs.semanticscholar.org/85ee/dfd6515cc56ec39e68d4f7a020a89294caef.pdf? ga=2.43192 $\underline{485.1457151951 .1584894296-675185541.1584894296}$
} 
hosszú távú trendvonalat látunk, amely csaknem negyven éven át töretlen növekedést hozott Nyugat-Németországban.

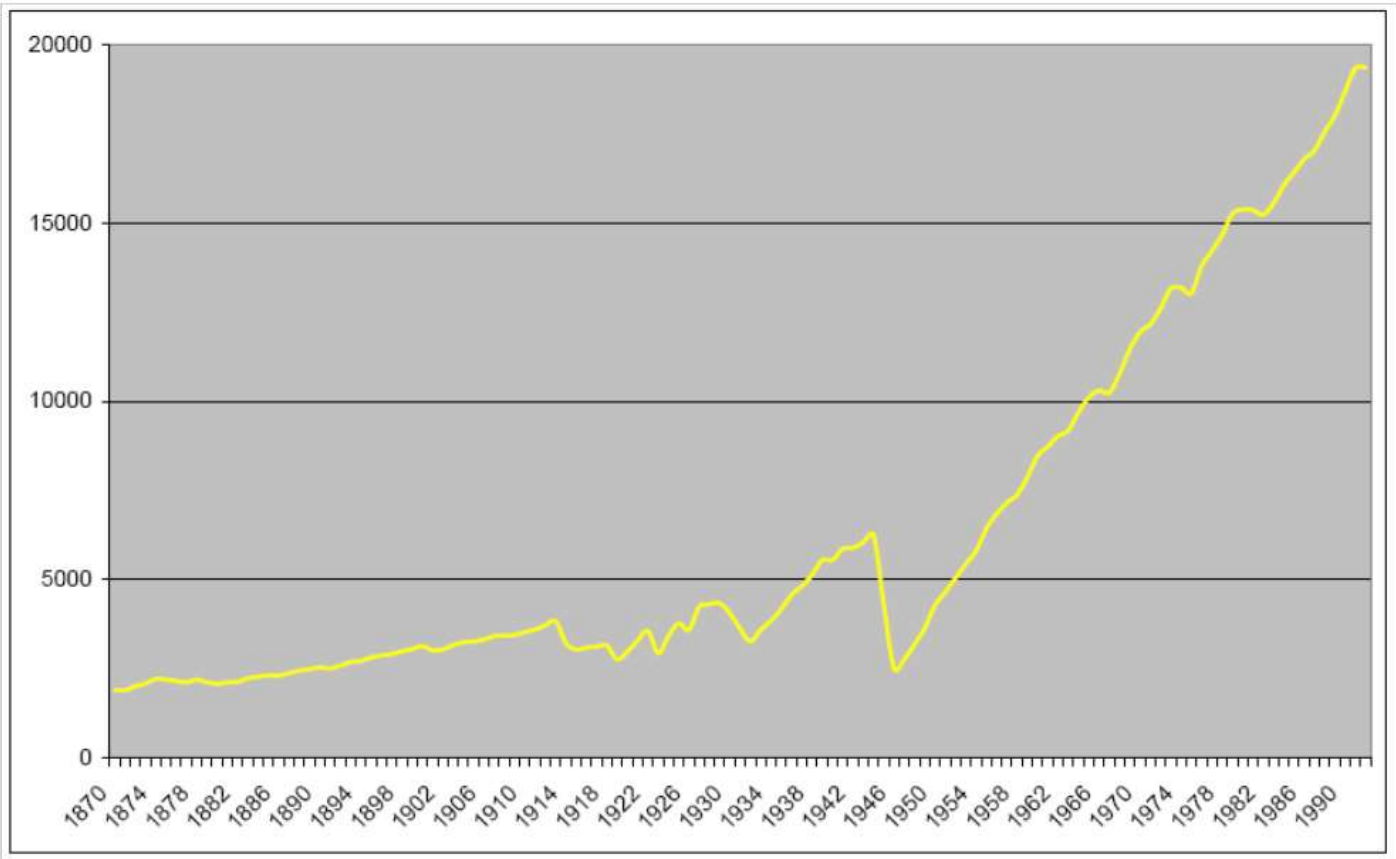

Németország fejenkénti bruttó hazai terméke 1990-ben. Forrás: Maddison, 1995, Historische Datenbank (2009) in: Bush-Land, 2009.

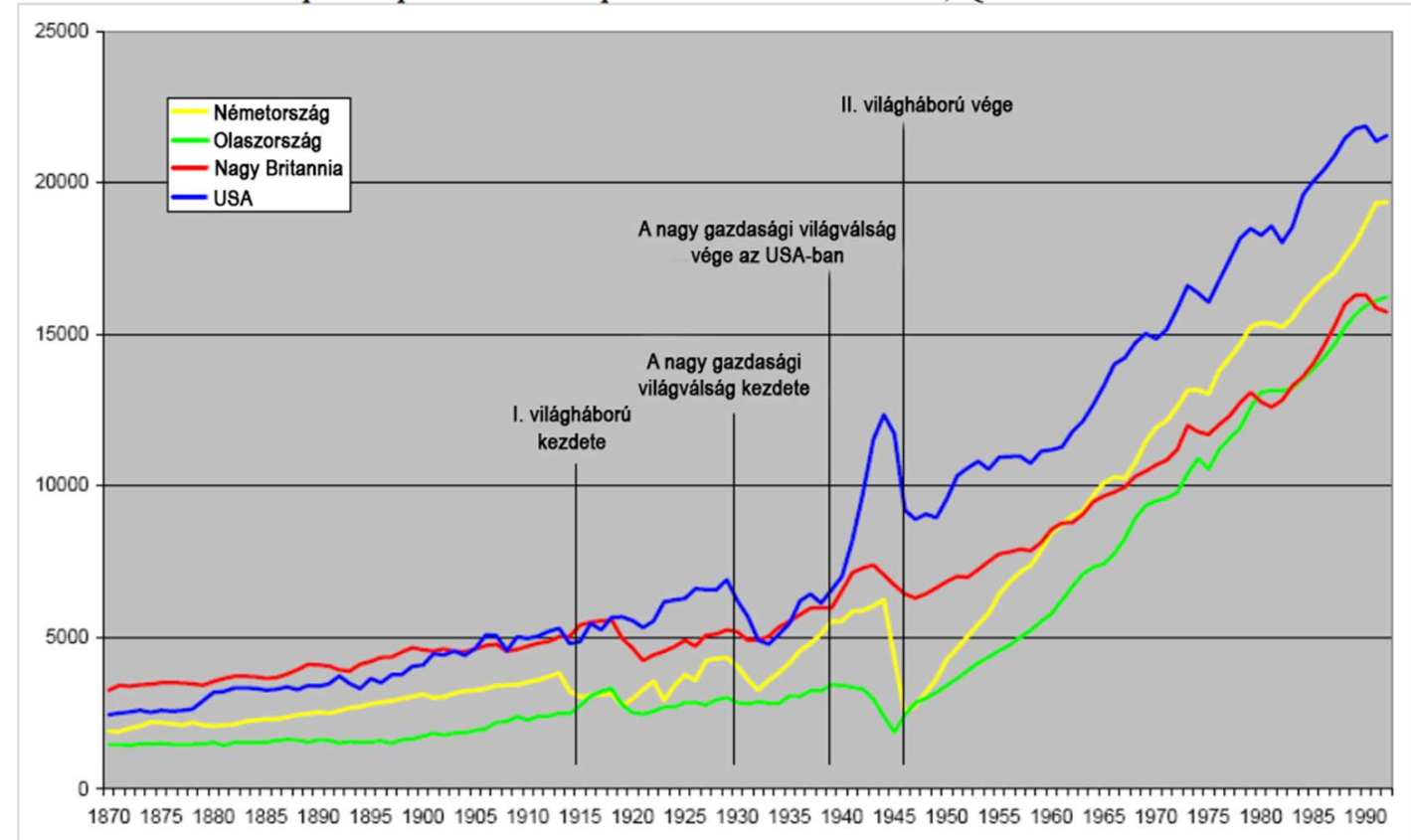

Vásárlóerö-paritáson mért jövedelem/fö, dollárban kifejezve, 1870 és 1990 között. Forrás: Maddison, 1995, Historische Datenbank (2009) in: Bush-Land, 2009.

A fentiek az ordoliberális gazdaságstratégiai tervezés gyakorlati megvalósulására jó példát szolgáltatnak. A világgazdaság ciklusaitól egyetlen nemzetgazdaság sem tudja függetleníteni magát, de Nyugat-Németország képes volt rá, hogy csaknem két 
évtizeden át fenntartson egy olyan gazdasági növekedést, melynek görbéje meredeken emelkedik, majd csak igen röviden törik meg. Történik mindez akkor, amikor a világ nyugati felén több társadalom is elkezdi keresni a jóléti állam modelljének alternatíváját. A Német Szövetségi Köztársaság ezekben az években is kitartott a korábban felvázolt gazdasági keretrendszere mellett, mert már a háború utáni években kereste - és meg is találta - a harmóniát a piaci erők szabadjára engedése és a társadalmi szintủ szolidaritás között.

Az NSZK abban tér el az Egyesült Államoktól és az Egyesült Királyságtól, hogy mialatt utóbbiak az olajválság első jeleit a neoliberalizmus individualista szemléletü és szolidaritáshiányos szociálpolitikájával kívánták megoldani, addig a vasfüggöny nyugati felén élő németek számára változatlanul ott állt a szabadság és a szolidaritás értékkettőse által épített társadalom. Ez a gazdasági keretrendszer ütésállónak bizonyult a világgazdasági válság közepette, ugyanakkor, szemben a neoliberalizmussal, nem hagyta magára a szerencsétlenebbül járt társadalmi csoportokat, ezzel lényegében azokra a klasszikus liberális gondolkodókra is támaszkodott, akik szintúgy hangsúlyozták, hogy a közösség nem hagyhatja magára a nyomorgókat.

Az ordoliberalizmus több mindent ötvöz. A klasszikus liberalizmus fejezetében tárgyalt erkölcsi kérdések éppúgy szerepet kapnak társadalomképének kialakításában, mint a piaci folyamatok teremtette hatékonyságban való mély hit. A szabályrendszer stabilitása és annak hangsúlyozása, hogy piacgazdaság, demokrácia és jogállam egymást erősítő tényezők, meghozta a lehető legtöbbek számára a jólétet, a történelem tanulságaiból felépült emberkép pedig rendszerszintü szolidaritásra kötelezte a társadalomszervezőket, ami nem pusztán óriási gazdasági teljesítményre, de a társadalmi kohézió kialakítására is képes volt.

Ezeket a vállalásokat szupranacionális szinten az Európai Unió igyekszik megvalósítani - több-kevesebb sikerrel. A szabadság kiterjesztésének folyamatai, a leszakadók fejlesztésének támogatásai, valamint a jogállam és a demokratikus intézményrendszer stabilitásáért tett fáradozások ugyanabba az irányba mutatnak, mint a nyugat-német törekvések. Kérdés, hogy egy ilyen nagy területü és soknemzetiségü közösséget lehet-e, és ha igen, hogyan kormányozni annak érdekében, hogy a szabadság és a szolidaritás értékkettőse ugyanúgy megjelenjen a polgárok életében, mint ahogyan az ordoliberálisoknál. 


\section{XXI. SZÁZADI KIHÍVÁSOK: SZABADSÁG ÉS SZOLIDARITÁS, VALAMINT SZABADSÁG ÉS BIZTONSÁG KÉRDÉSEI AZ EURÓPAI UNIÓBAN}

Egy liberális demokráciában azért van esélye mindenkinek az élet magasabb minőségét megtapasztalni, mert nem pusztán a piacgazdaság hatékonyságán keresztül történő életszínvonal emelkedése a szempont, hanem az is, hogy minden ember méltósága és jogai biztosítottak legyenek. Egy liberális demokrácia, illetve az arra ráépülő jogállami rendszer jellemzöje, hogy mindenkit megillet az egyenlő bánásmód és az egyenlő méltóság elve, mert a jogrendszer nem tesz különbséget ember és ember között. A jogállam minden állampolgárnak lehetőséget biztosít arra, hogy békében és háborítatlanul élhesse az életét: senkit sem diszkriminálhatnak egy ilyen szisztémában olyan tulajdonsága miatt, amely nem árt másoknak, és amely eltér a többségi társadalomtól.

A 21. században olyan kihívásokkal találta szembe magát az emberiség, mint gazdasági válságok, mélyülö társadalmi szakadékok, polgárháborúk, etnikai forrongások, nukleáris fenyegetés, szegénység ördögi köre a világ számos régiójában. (Simai, 2016.) Az emberek biztonságérzete ilyen helyzetekben megrendül.

Az Európai Unió egészében és egyes tagországaiban egyaránt a politikai vezetők keresik a lehetőségét annak, hogyan harmonizálják a szabadságot és a biztonságot, hogyan biztosítsák a külső határok védelmét és a közbiztonságot anélkül, hogy a polgárok szabadságát korlátoznák, és ebben az útkeresésben a liberalizmus támpontokat adhat. (E fejezet még a koronavírus-járvány első európai heteiben került lezárásra, így csak a végleges doktori értekezés tartalmazza majd, hogy az Európai Unió tagországaiban a szabadság korlátozása mint „védelmi reakció” hogyan ment végbe.)

Minden eszmerendszer elméleti és gyakorlati képviselőinek megvannak a saját válaszai arra, hogyan kívánják kezelni ezeket a világszintủ kihívásokat. A liberálisok változatlanul a polgárok szabadságának garanciái mellett kívánnak választ adni e kihívásokra, őrködni a XX. század második felének nyugati vívmányai fölött, őrizni a demokratikus intézményrendszer, a jogállam és a piacgazdaság háromszögét, melyek - hatékony állami müködés mellett - garantálják az emberi méltóságot, a döntéshozatal és a piaci verseny igazságosságát.

Kérdés, hogy a populizmus új hullámának térnyerésével hogyan változnak az európai társadalmak, a nyugati szövetségi rendszer, és hogy az 1949-ben lefektetett új 
világrendhez való alkalmazkodási folyamatban milyen zökkenők várhatók, illetve ezeket a zökkenőket milyen eszköztárral (beleértve az eszmei összefüggéseket is) képes kezelni.

Az új kihívások miatt Európában minden eddiginél nagyobb vita bontakozott ki felelősségvállalásról, egymás közti szolidaritásról, határvédelemről, de még a négy szabadság elvéről is. (Fehér könyv Európa jövőjéről, 2017.)

A dolgozat elemzi az elmúlt évek világeseményeit a polgárok politikai és gazdasági szabadságjogainak csorbulása szempontjából, majd az Európai Unión belül a sérült jogállamisággal müködő országok helyzetét veszi górcső alá. A fejezet kérdése, hogy a 2017-ben megjelent Fehér könyv következő időszakra vonatkozó lehetséges forgatókönyvei (melyek csak alapesetek, számos lehetséges kimenetellel), valamint a 2021-27-ig tartó európai költségvetési ciklus új játékszabályai hogyan segítik az uniós alapértékek megőrzését a közösségben, melyben a liberalizmus évtizedek óta meghatározó rendező elv. Természetesen a dolgozat nem állítja, hogy az Európai Unió egy liberális szövetség, hiszen alapítói között szociáldemokrata, konzervatív és liberális meggyőződésű társadalomszervezőket is találunk. A közösség vívmányait, elsősorban a politikai szabadságjogokat, melyekért a liberalizmus nemzeti szinten több évszázad alatt sikeresen küzdött meg, azok sem kérdőjelezik meg, akiknek politikaitársadalmi meggyőződése és értékrendszere konzervatív vagy szociáldemokrata alapokon nyugszik.

E fejezet azért született, mert gyakorlati példát kíván szolgáltatni arra, hogy a világban végbement egy folyamat, melynek eredményeként csökkent a szabadság, számos társadalomban. Az Európai Unió a Human Freedom Index által elemzett évben, 2017ben felvázolt lehetséges forgatókönyveket, amelyeken a közösség haladhat tovább, valamint mára beépített a kohéziós- és regionális alapokból származó támogatási rendszerbe egy olyan feltételrendszert, amelyen keresztül talán e világszintü szabadságcsökkenő folyamatnak veheti elejét.

\subsection{Világszerte csökkenő szabadság}

A Human Freedom Index 2017-es felmérése alapján a polgárok által megélt szabadság általánosságban csökkent a világban. Empirikus kutatások alapján bizonyított, hogy ahol sérül a jogállam, ott a szabadságjogok is veszélyben vannak, és bár kimutatható a szabadságjogok gazdasági haszna - amennyiben korlátozzuk az emberek szabad mozgását a határokon át, az a kereskedelem volumenét is csökkenteni fogja-, mégis 
csökkenés ment végbe a világon a szabadságjogok gyakorlásában. A világ kevésbé szabad, a világ kevésbé liberális - állítja a Human Freedom Index 2017-es adatsora. (HFI, 2017.)

Az Európai Unió szabadság és jogállamiság melletti elköteleződését mutatja, hogy a világ harminc legszabadabb országa közt tizenkilenc uniós tagországot találunk.

\begin{tabular}{|c|c|c|}
\hline Ország & $\begin{array}{l}\text { Helyezés szabadságjogok } \\
\text { érvényesülése } \\
\text { szempontjából }\end{array}$ & $\begin{array}{l}\text { Rangsorban változás az } \\
\text { előző kutatás adataihoz } \\
\text { képest }\end{array}$ \\
\hline Svájc & 1. & +1 \\
\hline Hong Kong & 2. & -1 \\
\hline Új-Zéland & 3. & 0 \\
\hline Írország & 4. & +4 \\
\hline Ausztria & 5. & 0 \\
\hline Finnország & 6. & +1 \\
\hline Norvégia & 7. & +2 \\
\hline Dánia & 8. & -2 \\
\hline Hollandia & 9. & +3 \\
\hline Egyesült Királyság & 10. & +1 \\
\hline Kanada & 11. & -7 \\
\hline Ausztria & 12. & -1 \\
\hline Svédország & 13. & +2 \\
\hline Észtország & 13. & +3 \\
\hline Luxemburg & 13. & -1 \\
\hline Németország & 16. & -4 \\
\hline Egyesült Államok & 17. & +7 \\
\hline Tajvan & 18. & +8 \\
\hline Szingapúr & 18. & +16 \\
\hline Litvánia & 18. & +2 \\
\hline Málta & 21. & -4 \\
\hline Belgium & 22. & -5 \\
\hline Portugália & 22. & -3 \\
\hline Lettország & 24. & -2 \\
\hline Ciprus & 25. & +4 \\
\hline
\end{tabular}




\begin{tabular}{|l|l|l|}
\hline Csehország & 25. & -4 \\
\hline Japán & 27. & -1 \\
\hline Románia & 28. & 0 \\
\hline Koreai Köztársaság & 29. & +1 \\
\hline Spanyolország & 30. & +6 \\
\hline
\end{tabular}

Forrás: Human Freedom Index, 2017

A kutatás értelmében jelentős korrelációt mutat az egyéni (politikai) és a gazdasági szabadság, utóbbihoz viszont szigorú versenyszabályozásra és jól működő jogállamra van szükség. A gazdasági szabadság azonban csak szükséges, de nem elégséges feltétele annak, hogy a polgárok szabadságban élhessenek. Szeretnék röviden visszautalni Dardot és Laval (2013.) állammal kapcsolatos fontos megjegyzésére, miszerint ez a felfogás korántsem jelent gyöngébb államot: az állam más típusú feladatát (a szabadságjogok és a tisztességes piaci magatartás garanciáit) jelenti.

Czeglédi Pál szerint „a gazdasági szabadság és a polgári szabadságjogok együttes kikényszeritése azt jelzi, hogy az egyének alkotmányos preferenciái nagy súlyt adnak az emberi szabadság önmagáért való kikényszeritésének, s éppen ez az innovációra épülö gazdasági növekedés egyik feltétele" (Czeglédi, 2012. p. 2). Ez nem más, mint a tudásalapú gazdaságra való átállás, amely feltételezi az egyének oktatási rendszerhez való szabad hozzáférését, ezen keresztül pedig biztosítja a társadalmi mobilitást. „Egy nép annál demokratikusabb, minél nagyobb szerepet játszik nyilvános ügyeiben a gondolkodás, a reflexió és a kritikai szellem". (Durkheim, 1957, 1992. p. 128.) Ehhez azonban jó iskolarendszer kell, amely képes rá, hogy a lehető legtöbbeknek megtanítsa a világban való eligazodás képességét, legyen szó tudományos, demokratikus, állampolgári ismeretekről.

Friedrich Naumann (1909) szerint az embereket az állam megbünteti, ha „a járdán lovagolnak”, vagy ha nem oltatják be a gyerekeiket, lehetőség szerint beszednek tőlük adót, de a legkevésbé sem jut eszükbe az, hogy politikai hatalmuk lenne, holott minden társadalmat fejlesztene a felismerés: a hatalomnélküliek valójában hatalommal bírnak a hatalmat gyakorlók fölött. Ehhez a megállapításhoz azonban a polgároknak tudásra van szükségük. Emiatt állítja Nico Stehr, hogy „, a szabadság a tudás leánya”. (Stehr, 2017.)” A tudás, helyesebben szólva: knowledgeability - és annak birtokában a (mind a tényleges, mind pedig a szubjektív) kompetencia érzése - úgy léphet fel, például állami intézményekkel szemben, mint az állitólagosan gyengébb társadalmi helyzetüek 
ellenállásának forrása, s nem csak azt a szerepet láthatja el, amint attól gyakrabban tartanak, hogy a hatalmasok hatalmának megtartását biztositsa a társadalomban." (Stehr, 2017. p. 11.) E tudás híján a társadalom nem birtokolja a képességet, hogy maga szerezzen ismereteket a világról, és alkosson véleményt arról, amit akár a sajtóban olvas, vagy a hírekben hall. A hatalmat gyakorlók ezt kihasználva adhatnak kész világképet a társdalom tagjainak. Ez történik a populizmus térnyerésével. A populizmus harmadik hullámának képviselői ugyanúgy nem érdekeltek a társadalom edukációjában, mint elődeik.

Három győzelem - Trumpé, a Brexit-pártiaké, valamint az európai populista pártok elöretörése - nyilvánvalóvá tette, hogy valami megváltozott, ami kihívás elé állítja a liberális demokráciát. „Ezek az események azt jelezték számukra, hogy nincs mód továbbra is lekicsinyelni a „veszélyt”, a választókhoz fellebbezö „populisták” a liberális demokrácia szive közelébe értek." (Gyurácz, 2017. p. 5.) További nehézség, hogy a társadalmak ugyan fontosnak tartják azokat a jogokat, amelyek a szólás- vagy a gyülekezési jog szabadságáról szólnak, ugyanakkor a tolerancia kevésbé fontos számukra mint érték. Amennyiben a jogrendszer tiszteli a másságot, enyhíteni kívánja az esélyek egyenlőtlenségét, biztosítani kívánja a polgárok egyenlő méltóságát, de a társadalom ezt nem tartja fontosnak - vagyis a szabadságra igényt tart, de a felelősségvállalásra nem -, akkor sem érvényesülnek az alapvető szabadságjogok egy adott országban. (HFI, 2017.)

„(...) az állam dolga éppen az, hogy az egyén jogainak érvényt szerezzen. ” (Kis, 2014: p. 159.) Arra ugyanis egy jogállamban nem jogosult senki, hogy a másik jogait vagy méltóságát csorbítsa. Az embereknek képessé kell válniuk a saját jogaik tiszteletére. (HFI, 2017.) Ugyanakkor problémás, hogy „Az állami akarat demokratizálásából általában hiányzik a cselekvés alapjául szolgáló tudás megfelelö demokratizálása". (Otto Neurath, 1908, 1998. p. 120. - in Stehr, 2017.) A tudástársadalommá való átalakulás viszont hat a politikai rendszerre, mert kiszélesíti a polgárok cselekvési lehetőségeit, ezáltal ők nehezebben kizárhatók a politikai részvételből, nagyobb politikai ítélöképességgel rendelkeznek, jobban követelik a transzparenciát, a politikusok elszámoltathatóságát, így ők a „politikai piac” minden korábbinál tájékozottabb és talán észszerübb résztvevői. (Stehr, 2017. p. 281-288.)

A „gazdasági és polgári szabadság mértéke a tulajdonjogok definiálására és kijelölésére vonatkozó, alkotmányos szinten meghozott társadalmi döntés kérdése" (Czeglédi, 2012. p. 9.). - írja Czeglédi Pál. Ennél ez egy árnyaltabb kérdés, az állítás 
pedig nem is feltétlenül igaz. A jogállamban a szabadságot nem lehet korlátozni, az alkotmány legfeljebb ennek garanciája, de nem szabályozó eszköze. Az ordoliberalizmus sikerének egyik kulcsa éppen abban rejlik, hogy pontosabban meghatározta a liberális eszmerendszer gyakorlati megvalósítóinak körében használt kvázi-definíciót, miszerint „az egyik ember szabadságának korlátja a másik ember szabadsága". Azért könnyü meghatározni, hogy hol kezdődik a másik ember szabadsága, mert a piackompatibilis gazdasági keretrendszer és az egyének szabadságát célzó társadalomszervezési ajánlat pontosan szabályozza, hogy meddig tart mindenkié. (Triviális példával élve az adóelkerülésre vagy a szerződő partner átverésére egészen biztosan nem terjed ki.) Ebben a felfogásban onnan kezdődik a polgárok szabadsága, hogy betartják a szabályokat mindannyian, így kerülhetők el a piaci és társadalmi kudarcok hosszú távon is.

A populizmus térnyerése, a jogállami normák csorbulása, a biztonságpolitikai kérdésekre adott szabadságjog-csorbító válaszok, vagy a gazdasági válság megoldására használt protekcionizmus mind abba az irányba hatnak, hogy az egyéni és gazdasági értelemben vett szabadság csökken még a szabad világban is. (HFI, 2017.) Amennyiben az állam és a polgárok jogcsorbító magatartást tanúsítanak (más) állampolgárok felé, mind gazdasági, mind jogi értelemben segítségül hívható a liberalizmus e kihívás korrekciójára: „A másik oszlop a tulajdon. (...) a magántulajdon nem csak a másik emberrel szemben jelent védökeritést, hanem az állammal szemben is.” (Röpke - ford. J. Horváth - 2000. p. 39.)

A fentiek alapján a jó iskola, valamint a szabadságjogokat tiszteletben tartó társadalomszervezés is szükséges ahhoz, hogy a XXI. századi kihívásokra megfelelő válaszokat találjunk. A gyakorlati kihívásokra az Európai Unió eleddig sosem válaszolt a szabadságjogok csorbításával, bár kétségtelenül nem teremtett közös iskolarendszert - sőt, még irányelveket sem a tagországoknak arra nézve, hogy hogyan szervezzék az oktatásukat. Azonban fontos figyelnünk arra, hogy az uniós alapértékek közt mindig is a szabadságkiterjesztés, valamint ennek hosszú távú garanciái álltak az elsődleges célok között, még a jelenlegi, általánosan csökkenő szabadság környezetében is. 


\section{2. Új, gyakorlati kihívások és liberális eszmetörténeti fordulópont}

Jacque Delors Jean Monnet-t idézve azt írja: „Fokozatosan kell megteremteni az európai férfiak és nők között a legmesszemenőbb közös érdeket, amit a szükséges szuverenitással felruházott közös demokratikus intézmények igazgatnak. Ez az a dinamika, amely nem szünt meg müködni az Európai Közösség kezdetei óta, szétzúzta az elöitéleteket, eltörölte a határokat, néhány év alatt kontinens méretüvé tágította a folyamatot, mely az évszázad folyamán formálta a jó öreg országainkat." (Delors, 2013. p. 91.) A közösség már a kezdetek kezdetén is a szabadságjogok kiterjesztése mellett érvelt, nem sértve a nemzeti szuverenitást, új szuverént hozva létre. „Igen, ismétlem, nemzeti büszkeségeinket nem kell eltörölnünk, éppúgy nem, mint ahogyan filozófiai vagy politikai preferenciáinkat sem! Végül is nem a megújult demokrácia bajnokai akarunk-e lenni? Az emberi jogok, a pluralizmus bajnokai.” (Delors, 2013. p. 92.) Ez a szemlélet egy nemzeti liberalizmuson túlmutató, nemzetközi liberalizmusban gondolkodik. Olyan eszmében, amely a már megharcolt nemzeti vívmányokat és szabadságjogokat nemhogy elvitatja, de éppen hogy megerősíti azokat.

Ugyan a neoliberalizmus gazdaságpolitikai fóáramba emelése mind társadalmi, mind gazdasági értelemben jó szolgálatot tett a hidegháború alatt, ez a korszak azonban lezárult. Rövid időre elláthatta volna a feladatot, hogy a posztszocialista országok társadalmainak tagjaiban is elültesse a gondolatot: az egyén felelős a saját életéért, erre a populizmus új hullámának térnyerése miatt már csak az üdítő kivételek esetében kerülhetett sor, mint az Oroszországtól minél nagyobb távolságot tartani kívánó Balti államokban, vagy az Ausztria közelségét és az európai integráció előnyeit ügyesen használó Szlovéniában.

Az Európai Unió a társadalmi-kulturális fejlődés, az integráció mélyebb fokának elérését számos dimenzióban segítette. A kultúra és az oktatás területén olyan programokat indított, amelyek segítségével nem pusztán gazdasági-politikai, de társadalmi-kulturális dimenzióban is közeledhetnek egymáshoz a tagországok. „ $A$ kultúra - egyre gyorsabb ütemben - állandó megújulási folyamaton megy át." (Lengyel-Szántó, 2005. p. 315)

A kelet- és közép-európai régió Európai Unióhoz való csatlakozása, a csoportos csatlakozás új fejezetet nyitott 2004-ben. Az integráció mélyebb szintjének lehetősége, az Európai Unió intézményrendszere, a négy szabadság hordozta lehetőségek - mint ösztöndíjak, csereprogramok, vagy éppen a kohéziós és regionális alapok - elhozták a 
kontinensre a törekvést, hogy közelebb hozzanak társadalmakat egymástól, és hogy csökkentsék a kulturális különbségeket európaiak és európaiak között. Lengyel és Szántó (2005) írtak arról, hogy optimista forgatókönyv szerint az európai integrációval párhuzamosan épülő regionalizáció ,felszabaditja majd a régiókat a nemzetállamok gyámkodása alól", ezzel pedig nagyobb esélyt teremtenek a regionális identitás megőrzésére, mint nemzetállami keretek között.

A nagyobb Európát az önrendelkezés magasabb szintjeként, és a heteronómia ellentéteként írják le. Felhívják a figyelmet azonban arra is, hogy a centrum és a periféria közti különbség így növekedni fog, mert meglehet, hogy a régiók az együttműködést a saját hasznukra fordítják majd. Kétségtelen az is, hogy az Európai Unió regionális és kohéziós alapjaiból felhasznált pénzeket a fejlettebb régiók gyakorta hatékonyabban használják fel, mint a fejletlenebbek, ez a lehetőség a legkevésbé fejlettek számára is adott, és megfelelő költségvetési fegyelem megléte mellett növelhető a hatékonyság.

A populizmus új hullámának megjelenése ugyan átmenetileg visszaveti ezeket a törekvéseket, de az európai és az észak-amerikai régió sosem volt közelebb ahhoz, hogy létrehozzon egy tényleges szabadkereskedelmi övezetet, amely már interkontinentális - elég a TTIP-re, vagy a CETA-ra gondolni.

Az EU-s csatlakozással a korábbi szocialista blokk országainak egy jelentős csoportja vált a kontinensszintű gazdasági és politikai integráció teljes jogú tagjává. A világkereskedelem regionalizációja abba az irányba halad, hogy egy trió vezesse: a nyugat-európai, az észak-amerikai és az ázsiai-csendes-óceáni régió. (BorrmannKoppmann, 1994.) Ennek a hármas felosztásnak korábban nem volt - nem lehetett részese a régió, melyhez Magyarország is tartozik, azonban az uniós csatlakozás megnyitotta az utat mind a kereskedelmi, mind a kulturális kapcsolatok szorosabbra füzéséhez.

A regionális kereskedelmi integrációk száma sosem látott mértékben indult növekedésnek a '90-es években. 2004-ben a számuk már 208 volt hatályos közülük a WTO szerint. Az EU, az EFTA, a MERCOSUR és a NAFTA is jelentősen növelte a tagországok közti kereskedelem volumenét, vagyis a gyakorlatban ellátták elméletben felvázolt feladatukat.

A regionális integrációs folyamatok gyakorlatilag természetesek. Szomszédos nemzetgazdaságok történelmileg müködnek együtt, gyakran évszázadok óta, ennek egy természetes tovagyürüző folyamata az, hogy bilaterális vagy multilaterális 
kereskedelmi egyezmények köttetnek olyan országok között, amelyek egy régió tagjai. (Gaulier et. al, 2004.) A szerzőtrió valamivel több mint egy évtizeddel később, mint Borrmann és Koppmann, már „eurafrikai”, amerikai és ázsia-óceániai regionális kereskedelmi övezetekröl beszélt - közös a két írásban, hogy triádokban gondolkodnak a világkereskedelmet illetően.

Eszerint a felosztás szerint azonban nem áll és nem is állhat meg a fejlődés motorja a korábbi vasfüggöny határainál Európában, mert a regionális integráció elmélyítésének egyik előfeltételeként támasztott gazdasági homogenitás (Békés, 1998.) elveszne, ezzel pedig a komplett térség versenyképessége gyengülne a többpólusúvá vált, globalizált világban. Az Uniónak a fentiek értelmében elemi érdeke segíteni a fejletlenebb területeket abban, hogy fejlődhessenek. A gazdasági integráció, a kohéziós és regionális alapok háttere korántsem egy idealista, kizárólag értékalapú intézmény: a gazdasági racionalitás vezérli, amely egybevág az Unió kulturális és politikai céljaival.

Ugyanígy van ez a tudomány és az oktatás területén. A legutolsó, lezárt hétéves költségvetési ciklus csak Erasmus-programra 3,1 milliárd eurót költött, hét év alatt 1,6 millió egyetemi hallgató és 300.000 akadémiai munkatárs, oktató szerezhetett külföldi tapasztalatot. A legnagyobb létszámban a 2013/14-es tanévben vettek részt diákok a programban, több mint 272.000 ember, mindez 80 millió euró ráfordítással. A kulturális értelemben vett regionalizáció ebben az esetben túlterjeszkedett az uniós határokon is: az EU-val szoros gazdaság- és társadalmi, valamint politikai együttmüködésben levő nemzetállamok, valamint a feltehetően uniós tagság előtt álló országok is részt vettek a programban. A 28 tagállamon felül Norvégia, Svájc, Izland, Törökország, és a költségvetési ciklus legutolsó évében először, a korábbi jugoszláv tagköztársaság, Macedónia is. (European Commission, 2015.) ${ }^{19}$

A programban résztvevő hallgatók közelről tapasztalják meg az Unió mottójául választott eszmeiség gyakorlati megvalósulását, a határok nemlétét, az otthonról hozott kulturális különbségek megléte melletti közös eszmecserét, építkezést, projektek és egyéb közös munkák létrehozását, emberi kapcsolatok felépülését. Csak Magyarországról 1998 és 2012 között 38.567 hallgató töltött el külföldi félévet a program keretén belül, számuk minden évben emelkedett. ${ }^{20}$

\footnotetext{
${ }^{19} \mathrm{http}: / /$ ec.europa.eu/

${ }^{20}$ http://piackutatas.blogspot.hu/
} 
Az Unió saját határain túlnyúló kapcsolatai abba az irányba mutatnak, hogy integrációs szálait az egyelőre nem uniós tagországokkal is szorosabbra kívánja füzni. Kulturális, tudományos és oktatási téren ilyen az Erasmus program kiterjesztése, ennél viszont jóval fontosabb a gazdasági integráció alapjául szolgáló kereskedelmi útvonalak és egyéb gazdasági kapcsolatok fejlesztése. A kereskedelmi folyosók, a korridorok kilépnek az Unió területéről, és további piacokat nyitnak meg az uniós tagországok számára. A korridorok mentén fekvő kereskedelmi partnerek pedig nem pusztán gazdasági értelemben, de a vállalati kultúrát tekintve is új fejlődési lehetőségekhez jutnak.

A fenti törekvések azonban nem voltak elegendők arra, hogy érdemben közeledhessen egymáshoz a mag-Európa és az újonnan csatlakozó tagországok teljes tábora.

A posztszocialista országok EU-integrációs folyamatának felgyorsulását követően elindult a kulturális közeledés is, a kereskedelmi és kulturális kapcsolatok egyidőben fejlődtek, azonban egyelőre az Unió ilyen irányú törekvései elégtelennek bizonyultak. Nem véletlen, hogy a közösség most már más, negatív ösztönzőket is beépít a rendszerbe. A Visegrádi Négyek, Románia és Bulgária körében fordulat állt be a 2008as válságot követően a jogállami és demokratikus intézményi-, valamint társadalomfejlődésben. A rendszerváltást követő első évek a tranzíciós válságok ellenére is az eufória jegyében teltek, a társadalom nagy hányada még a 2004-es uniós csatlakozáskor is hitt a nyugati szövetségi rendszerhez tartozás helyességében, a 2010es évet követően az EU-hoz együtt csatlakozó tízek fejlődési pályája elvált egymástól, politikai és társadalmi értelemben egyaránt.

Utóbbi országcsoportban több esetben sérült a jogállam, a demokratikus intézményrendszer, valamint az egyenlő méltóság és az egyenlő bánásmód elve. (HFI, 2017.) Lengyelország 10 helyet rontva a 32. helyet szerezte meg a legutóbbi rangsorban, Magyarország 6 hellyel visszacsúszva már csak a 44. Csehország 4 helyet rontott, de még így is a 25 . helyet foglalja el, míg Románia, pozícióját megőrizve, szintúgy belefért az első harminc ország közé.

Míg az 1989-et megelőző időszakban a neoliberalizmus társadalmi egyenlőtlenségeket növelő hatása ellenére is elmondható volt, hogy szolgálta a társadalomfejlődést, addig „a történelem végének” hitt év után ez már nem volt így. (Fukuyama, 1989). A neoliberalizmus eszköztelennek mutatkozott a globális kihívásokra adható válaszok megtalálásában, és jól látszik az európai politikai térképen, hogy kizárólag azok a liberális közösségek és politikai pártok tudták megtartani (vagy visszaszerezni) a 
választók bizalmát, amelyek ezt az eszmetörténeti háttérmunkát vállalva, új liberális irányt vázoltak fel a társadalom számára. Az irány sokféle volt, mert míg a jelenlegi Franciaországban egy jobboldali liberális irányt találunk, addig például a német Szabad Demokrata Párt egy klasszikus értelemben vett centrista párt, amit baloldalisággal nehéz vádolni, azonban visszalendítették a korábbi jobboldali irányból a pártot egy társadalmi értelemben véve szolidárisabb programhoz. (Bundestagswahlprogram der FDP, 2017.)

Emiatt az a dolgozat egyik állítása, hogy nem az eszmerendszerben keresendő a probléma, hanem az eszmetörténeti szempontból hozzánk időben még nagyon közeli szakaszában, a neoliberalizmusban. A neoliberalizmus a kollektivizmussal való szembehelyezkedés és az egyéni felelősségvállalás tanulásának idején jó szolgálatot tett egy következő társadalom- és gazdaságfejlődési lépcsőfok eléréséhez, azonban a leszakadó rétegek számára nem volt mondanivalója, és ami volt, az tovább rontott a helyzeten. A hidegháború idején hasznos tulajdonsága hosszú távon társadalomszervezési hiányosságot teremtett: egyre nagyobb feszültségekhez vezetett, hogy a leszakadó rétegeknek nem volt mit mondania, sőt, a neoliberalizmust gazdaságstratégiai tervezői képességei is cserbenhagyták, amikor azok nem vegyültek felelősségvállalással. (Duménil-Lévy, 2013.)

Az Európai Unió szakított ezzel a gyakorlattal, a szabadság és a szolidaritás közösségét hirdette, miközben a Római Szerződés óta eltelt 70 évben a béke szigetét teremtette meg az addig folytonosan háborúzó kontinensen. Az Európai Bizottság fontosnak tartja, hogy Európa polgárai felé érthetö üzeneteket fogalmazzon meg az Európai Unió mindennapi életre vonatkozó előnyeiről. Talán a legerősebb ezek közül az előnyök közül, hogy mióta az európai közösség gazdasági integrációs folyamatokat indított el, tagjai között megszünt a háború. Adam Smith koráig kell visszamennünk az időben az alapgondolatért, amelynek gyakorlati megvalósulását az alábbi ábra szemlélteti.

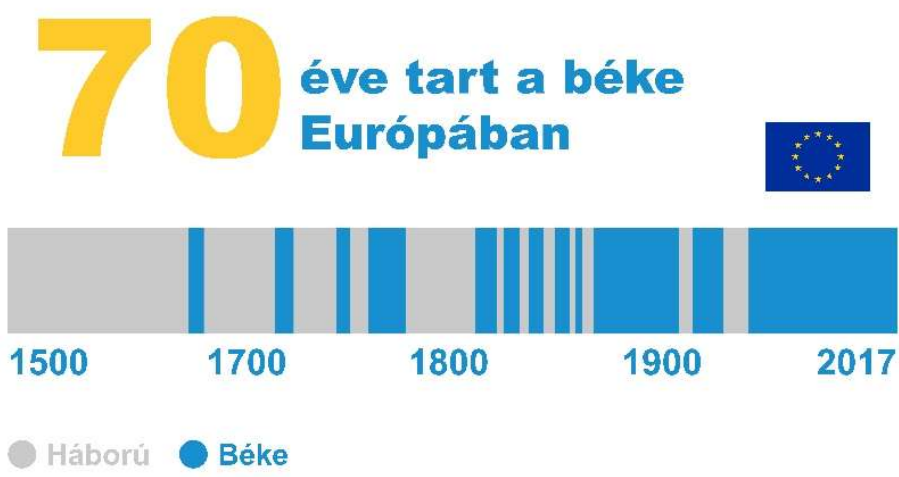


Forrás: Európai Bizottság, Fehér könyv Európa jövőjéről

\subsection{Az Európai Unió lehetséges válaszai a fennálló kihívásokra}

Régen fegyverekkel vetettek véget politikai rendszereknek, napjainkban azonban a jogállami elveken alapuló demokratikus intézményrendszer kialakítása a kérdés. Az még nem tekinthető jogállamnak, ha a parlamentet demokratikus keretek közt választják, amennyiben a jogállami normák sérülnek a kormányzás következtében, a demokratikus választások ellenére sem beszélhetünk liberális demokráciáról. (HFI, 2017.) Ha Kis János (2000) gondolatát kölcsönözzük ebben a kérdésben, miszerint az államnak éppen az a feladata, hogy az állampolgárok jogainak érvényt szerezzen, akkor a demokratikus felhatalmazást nem lehet egyéni vagy közösségi jogsértésre használni. A törvényhozó és végrehajtó hatalom felelős azért, hogy a jogérvényesülés az emberek mindennapjaiban ne sérüljön. Ez a felelösség a piacgazdasági keretek közt mozgó gazdasági szereplőkre is kiterjed.

A gazdasági fejlődés láthatóan függ a gazdasági liberalizációtól. (HFI, 2017.) A piac képes a hatékony elosztásra és a magasabb jövedelmek kitermelésére, még a szegények körében is, megfelelő szabályozással képes megteremteni a hatékonyság és igazságosság összhangját. „Arra a belátásra kell jutnunk (...), hogy a piacgazdaság olyan gazdasági rend, amelynek egy bizonyos társadalmi és erkölcsi rend felel meg. Olyan világrend, amelyet jobb szó hiján polgárinak kell neveznünk.” (Röpke - ford. J. Horváth - 2000. p. 39.) Jacques Delorst figyelmesen olvasva kitünik a sorok közül, hogy az Európai Unió alapítói tisztában voltak azzal: a piac nem oldja meg az értékrendi különbségeket, ugyanakkor az értékrend az, ami lefekteti az új Európa alapjait. (Delors, 2013.)

A vállalkozói szabadság, az egyének gazdasági aktorként vett szabadsága, a demokrácia megjelenése a piaci folyamatokban mind olyan kérdések, amelyek segítik a társadalmat, hogy új gazdasági és társadalmi egyensúlyt találjon. A gazdasági szabadsággal élő vállalkozók, munkavállalók és vállalatvezetők egy ilyen keretrendszerben tudnak tanulni a piactól, és felelősségvállalásukon keresztül tovább erősítik a polgári öntudat fejlődését, ezen keresztül gátolják a zsarnokság kialakulását. „Amíg csak e közös piac megvalósitásáról volt szó, addig a politikai tétek nem voltak világosan láthatók. Mihelyt elhatároztuk, hogy egy közös pénz felé haladunk, vagy megvetjük egy közös kül- és biztonságpolitika alapjait, ez az egész politikai szférát érinti, a nemzeti közösség jövőjét kötelezi el. Vitát és elmélyült gondolkodást igényel." 
(Delors, 2013. p. 16.) A nyugat-európai társadalomszervezők elkövették a hibát, hogy úgy gondolták, a vitáik és demokratikus vívmányaik eredményeként a jogállami, piacgazdasági és demokratikus fejlődés egyirányú utca. Csak az elmúlt években vált nyilvánvalóvá, hogy bőségesen találunk példát arra: egy társadalom visszafordul ezeken az utakon, és a szabadságjogok kiterjesztési folyamatában nem elöre halad.

Sem elméleti, sem gyakorlati szakemberek nem tudták előre jelezni akár még néhány évvel ezelött sem, hogy a liberális demokráciára egy más, több mint száz éve elfeledett hullám, a 19. század nacionalizmusa is veszélyt jelenthet majd. Giuseppe Mazzini neonacionalizmusa meröben hasonlít a vaskancellár, Ott von Bismarck társadalomképére és nemzetfelfogására. Putyin despotizmusa mind hazájában, mind külföldön népszerü, a Kínai Népi Demokratikus Köztársaság gazdasági modellje pedig sokak szemében olyan, mintha méltó kihívója lenne a piacgazdaságnak és a jogállamnak, holott ez nincs így. (Marshall, 2018.) Többek között azért fontos a liberalizmus megújulási képessége, hogy ezekre a kihívásokra megfelelő választ tudjon adni.

Kérdés, hogy az európai közösség képes-e lépéseket tenni annak érdekében, hogy a folyamat visszájára forduljon, és a demokratikus, valamint a jogállami fejlődés útjáról átmenetileg vagy tartósan letért tagországokat segítse a jogállam felé való fejlődésben. Az új kihívások nyomán Európa felismerte, hogy szükség van a liberális eszmerendszer által teremtett intézményrendszerek és társadalomszervezési ajánlat megújulására, hiszen a liberalizmusnak nem pusztán hirdetnie kell a piacot, de piacképessé kell válnia a kétségtelenül sokakat hívogató, azonban emberi méltóságot nem tisztelő rendszerekkel szemben.

A verseny, melyet a liberális eszmerendszer maga szorgalmazott a liberális demokráciáért folytatott küzdelemben, most maga kezdte el visszaszorítani azt a teret, amelyben a polgárok szabadsága megfelelő módon biztosított. Európa nem pusztán a 2008-as világválságból való lassú kilábalás miatt néz szembe nehézségekkel, de csökkenő népessége, az európai integráció mind jobban vitatott mivolta miatt is. (Fehér könyv Európa jövőjéről, 2017.) A közösség közeljövője is erősen vitatott, amire az Európai Bizottság 5 lehetséges forgatókönyv kidolgozásával és azok társadalmi vitára bocsátásával válaszolt a bevezetőben és a fentiekben vázolt gazdasági, társadalmi és politikai kihívásokra. 


\section{Forgatókönyv: Minden megy tovább}

E forgatókönyv azt jelenti, hogy „a 27 tagú EU továbbra is a munkahelyteremtésre, a gazdasági növekedésre és a beruházásokra összpontosit, ennek érdekében megerösíti az egységes piacot és fokozza a digitális, a közlekedési és az energetikai infrastruktúrára irányuló beruházásokat." (Fehér könyv, 16. o.)

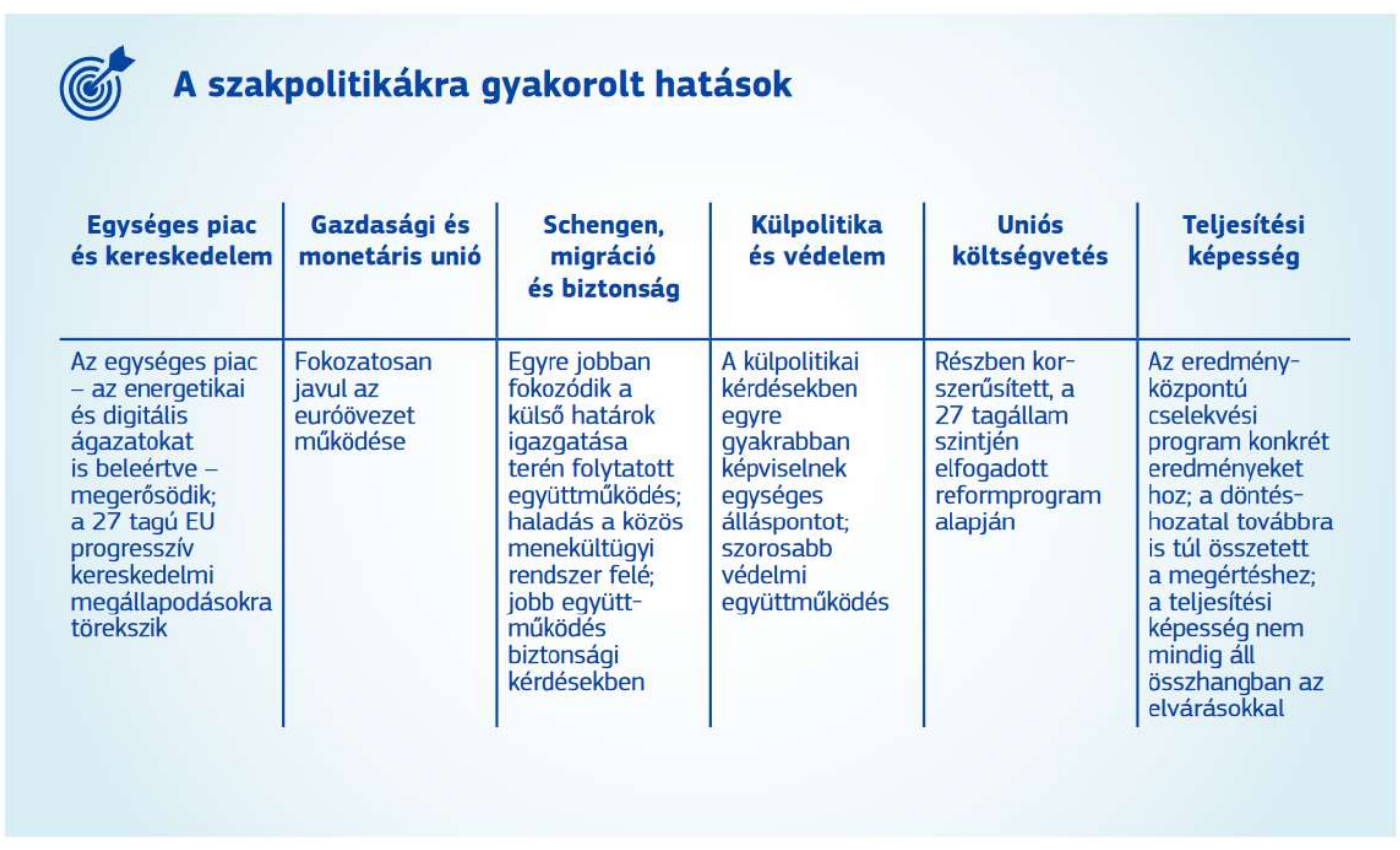

Forrás: Fehér Könyv Európa jövőjéről, 2017.

\section{Forgatókönyv: Csakis az egységes piac}

Ebben az esetben 2025-ig ,a 27 tagú EU létjogosultságát elsősorban az egységes árués tökepiac adja. A további elörehaladás attól függ, mennyire sikerül megállapodásra jutni a kapcsolódó szakpolitikai törekvésekröl és elöirásokról. Ez könnyebbnek bizonyul a töke és az áruk - továbbra is vámmentes - szabad mozgása területén, mint másutt." (Fehér könyv, 18. o.) 


\begin{tabular}{|c|c|c|c|c|c|}
\hline $\begin{array}{c}\text { Egységes piac } \\
\text { és } \\
\text { kereskedelem }\end{array}$ & $\begin{array}{l}\text { Gazdasági és } \\
\text { monetáris unió }\end{array}$ & $\begin{array}{l}\text { Schengen, } \\
\text { migráció } \\
\text { és biztonság }\end{array}$ & $\begin{array}{l}\text { Külpolitika } \\
\text { és védelem }\end{array}$ & $\begin{array}{c}\text { Uniós } \\
\text { költségvetés }\end{array}$ & $\begin{array}{l}\text { Teljesítési } \\
\text { képesség }\end{array}$ \\
\hline $\begin{array}{l}\text { Az egységes áru- } \\
\text { és tőkepiacot } \\
\text { megerősítik; } \\
\text { az elöirások } \\
\text { továbbra } \\
\text { is eltérnek } \\
\text { egymástól; az } \\
\text { emberek és a } \\
\text { szolgáltatások } \\
\text { szabad mozgása } \\
\text { nem garantált } \\
\text { teljes mértékben }\end{array}$ & $\begin{array}{l}\text { Az euróövezeten } \\
\text { belüli } \\
\text { együttmüködés } \\
\text { korlátozott }\end{array}$ & $\begin{array}{l}\text { Nincs egységes } \\
\text { migrációs politika } \\
\text { vagy menekültügyi } \\
\text { politika; } \\
\text { a biztonságra } \\
\text { vonatkozó } \\
\text { szorosabb } \\
\text { koordinációt } \\
\text { kétoldalúan } \\
\text { folytatják; a belső } \\
\text { határellenőrzés } \\
\text { szisztematikusabb }\end{array}$ & $\begin{array}{l}\text { Egyes külpolitikai } \\
\text { kérdésekkel } \\
\text { egyre inkább } \\
\text { kétoldalú } \\
\text { keretek között } \\
\text { foglalkoznak; } \\
\text { a védelmi } \\
\text { együttmüködés } \\
\text { a jelenlegi } \\
\text { helyzethez } \\
\text { képest nem } \\
\text { változik }\end{array}$ & $\begin{array}{l}\text { Új hangsúlyok az } \\
\text { egységes piachoz } \\
\text { szükséges } \\
\text { alapvető funkciók } \\
\text { finanszírozása } \\
\text { érdekében }\end{array}$ & $\begin{array}{l}\text { A döntéshozatal } \\
\text { valószínüleg } \\
\text { könnyebben } \\
\text { megérthető, ám } \\
\text { a közös fellépési } \\
\text { képesség } \\
\text { korlátozott; a } \\
\text { közös aggályokra } \\
\text { gyakran kell } \\
\text { kétoldalú } \\
\text { megoldásokat } \\
\text { találni }\end{array}$ \\
\hline
\end{tabular}

Forrás: Fehér Könyv Európa jövőjéről, 2017.

\section{Forgatókönyv: Aki többet akar, többet tesz}

Ebben az esetben bizonyos tagországok rendvédelmi szerveinek szorosabb együttmüködése valósulhat meg, elsősorban biztonságpolitikai és rendfenntartói feladatokban vállalnak közös felelősséget. A gazdasági együttmüködés terén is szorosabbra füzik kapcsolataikat, jelenti ez adókulcsok harmonizációját, szociális területen való együttműködést, vállalkozási és foglalkoztatási feltételek közös javítását.

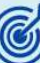

\section{A szakpolitikákra gyakorolt hatások}

\begin{tabular}{|c|c|c|c|c|c|}
\hline $\begin{array}{l}\text { Egységes piac } \\
\text { és kereskedelem }\end{array}$ & $\begin{array}{l}\text { Gazdasági és } \\
\text { monetáris unió }\end{array}$ & $\begin{array}{c}\text { Schengen, } \\
\text { migráció } \\
\text { és biztonság }\end{array}$ & $\begin{array}{l}\text { Külpolitika } \\
\text { és védelem }\end{array}$ & $\begin{array}{l}\text { Uniós } \\
\text { költségvetés }\end{array}$ & $\begin{array}{l}\text { Teljesítési } \\
\text { képesség }\end{array}$ \\
\hline $\begin{array}{l}\text { Mint a „Megy } \\
\text { minden tovább” } \\
\text { forgatókönyvben, } \\
\text { az egységes piac } \\
\text { megerösödik, } \\
\text { és a } 27 \text { tagú } \\
\text { EU progresszív } \\
\text { kereskedelmi } \\
\text { megállapodásokra } \\
\text { törekszik }\end{array}$ & $\begin{array}{l}\text { Mint a „Megy } \\
\text { minden tovább” } \\
\text { forgatókönyvben, } \\
\text { kivéve azon } \\
\text { országok } \\
\text { csoportját, } \\
\text { amelyek } \\
\text { elmélyítik az } \\
\text { együttmüködést } \\
\text { például az } \\
\text { adózás és a } \\
\text { szociális normák } \\
\text { terén }\end{array}$ & $\begin{array}{l}\text { Mint a „Megy } \\
\text { minden tovább” } \\
\text { forgatókönyvben, } \\
\text { kivéve azon } \\
\text { országok } \\
\text { csoportját, } \\
\text { amelyek } \\
\text { elmélyítik az } \\
\text { együttmüködést } \\
\text { például } \\
\text { biztonsági és } \\
\text { igazságügyi } \\
\text { kérdésekben }\end{array}$ & $\begin{array}{l}\text { Mint a „Megy } \\
\text { minden tovább" } \\
\text { forgatókönyvben, } \\
\text { kivéve azon } \\
\text { országok } \\
\text { csoportját, } \\
\text { amelyek } \\
\text { elmélyitik } \\
\text { a védelmi } \\
\text { együttmüködést, } \\
\text { és a hangsúlyt } \\
\text { a katonai } \\
\text { koordinációra } \\
\text { és a közös } \\
\text { felszerelésre } \\
\text { helyezik }\end{array}$ & $\begin{array}{l}\text { Mint a „Megy } \\
\text { minden tovább” } \\
\text { forgatókönyvben; } \\
\text { néhány tagállam } \\
\text { részére } \\
\text { kiegészítő } \\
\text { költségvetést } \\
\text { biztosítanak } \\
\text { azokra a } \\
\text { területekre, } \\
\text { amelyeken } \\
\text { többet kívánnak } \\
\text { tenni }\end{array}$ & $\begin{array}{l}\text { Mint a „Megy } \\
\text { minden tovább” } \\
\text { forgatókönyvben, } \\
\text { a } 27 \text { tagú EU } \\
\text { szintjén az } \\
\text { eredményközpontú } \\
\text { cselekvési } \\
\text { program } \\
\text { eredményeket hoz; } \\
\text { egyes csoportok } \\
\text { bizonyos } \\
\text { területeken } \\
\text { együtt többet } \\
\text { valósítanak meg; } \\
\text { a döntéshozatal } \\
\text { összetettebbé } \\
\text { válik }\end{array}$ \\
\hline
\end{tabular}

Forrás: Fehér Könyv Európa jövőjéről, 2017. 


\section{Forgatókönyv: Kevesebbet, hatékonyabban}

Ebben a forgatókönyvben az új kihívásokra való hatékonyabb közös válaszkeresésé a föszerep. Elsősorban a közös határvédelem, a terrorizmus elleni fellépés, a biztonságpolitikai együttmüködés és a szervezett bünözés elleni fellépés kap szerepet. Fontos még a közös Európai Ügyészség, a rendőri és igazságügyi szervek együttmüködése és az, hogy ebben az esetben az Európai Unió minden határvédelmi feladatot ellát, a parti őrség feladataival együtt.

\begin{tabular}{|c|c|c|c|c|c|}
\hline \multicolumn{6}{|c|}{ A szakpolitikákra gyakorolt hatások } \\
\hline $\begin{array}{l}\text { Egységes piac } \\
\text { és } \\
\text { kereskedelem }\end{array}$ & $\begin{array}{l}\text { Gazdasági és } \\
\text { monetáris unió }\end{array}$ & $\begin{array}{l}\text { Schengen, } \\
\text { migráció } \\
\text { és biztonság }\end{array}$ & $\begin{array}{l}\text { Külpolitika } \\
\text { és védelem }\end{array}$ & $\begin{array}{l}\text { Uniós } \\
\text { költségvetés }\end{array}$ & $\begin{array}{l}\text { Teljesítési } \\
\text { képesség }\end{array}$ \\
\hline $\begin{array}{l}\text { A közös előirások } \\
\text { a minimumra } \\
\text { korlátozódnak, } \\
\text { az uniós szinten } \\
\text { szabályozott } \\
\text { területeken } \\
\text { azonban a } \\
\text { jogérvényesítés } \\
\text { megerősödik; a } \\
\text { kereskedelemmel } \\
\text { kizárólag } \\
\text { uniós szinten } \\
\text { foglalkoznak }\end{array}$ & $\begin{array}{l}\text { Lépéseket } \\
\text { tesznek az } \\
\text { euróövezet } \\
\text { megszilárdítása } \\
\text { és stabilitásának } \\
\text { biztosítása } \\
\text { érdekében; } \\
\text { a } 27 \text { tagú EU } \\
\text { kevesebbet tesz } \\
\text { a foglalkoztatási } \\
\text { és szociálpolitika } \\
\text { egyes részein }\end{array}$ & $\begin{array}{l}\text { A határigazgatás, } \\
\text { a menekültügyi } \\
\text { politika és a } \\
\text { terrorizmus elleni } \\
\text { küzdelem terén } \\
\text { szisztematikus az } \\
\text { együttmüködés }\end{array}$ & $\begin{array}{l}\text { Az EU egységes } \\
\text { álláspontot } \\
\text { képvisel } \\
\text { valamennyi } \\
\text { külpolitikai } \\
\text { kérdésben; } \\
\text { európai védelmi } \\
\text { unió jön létre }\end{array}$ & $\begin{array}{l}\text { Jelentôsen } \\
\text { átalakitva, } \\
\text { hogy a } 27 \text { tagú } \\
\text { EU szintjén } \\
\text { elfogadott új } \\
\text { prioritásokat } \\
\text { szolgálja }\end{array}$ & $\begin{array}{l}\text { A feladatok } \\
\text { kiemelten } \\
\text { kezelésére vagy } \\
\text { feladására } \\
\text { vonatkozó } \\
\text { kezdeti } \\
\text { megállapodás } \\
\text { kihivásokkal } \\
\text { teli; bevezetését } \\
\text { követően a } \\
\text { döntéshozatal } \\
\text { megértése } \\
\text { könnyebbé } \\
\text { válhat; az EU } \\
\text { gyorsabban és } \\
\text { határozottabban } \\
\text { cselekszik ott, } \\
\text { ahol nagyobb a } \\
\text { szerepe }\end{array}$ \\
\hline
\end{tabular}

Forrás: Fehér Könyv Európa jövőjéről, 2017.

\section{Forgatókönyv: Sokkal többet együtt}

A védelem és a biztonság ebben a forgatókönyvben is kiemelt szerepet kapnak, azonban a gazdasági együttmüködés és egyéb szakpolitikai kérdések területén olyan szorosra füzné az együttműködést a közösség, hogy számos nemzetközi fórumon egyetlen képviselővel lépne fel az Unió. A globális környezet- és természetvédelem hangsúlyos szerepet kap, valamint a társadalmi felelősségvállalás világméretű szintje, a humanitárius segélyezés. Az energetika, a digitalizáció, a kutatás-fejlesztés területén tervez közös jövőt a közösség, költségvetési, adóügyi és szociális téren is folytatódik az együttmüködés, amennyiben ez a forgatókönyv érvényesül. 
(C) A szakpolitikákra gyakorolt hatások

\begin{tabular}{|c|c|c|c|c|c|}
\hline $\begin{array}{c}\text { Egységes piac } \\
\text { és } \\
\text { kereskedelem }\end{array}$ & $\begin{array}{l}\text { Gazdasági és } \\
\text { monetáris unió }\end{array}$ & $\begin{array}{l}\text { Schengen, } \\
\text { migráció } \\
\text { és biztonság }\end{array}$ & $\begin{array}{l}\text { Külpolitika } \\
\text { és védelem }\end{array}$ & $\begin{array}{c}\text { Uniós } \\
\text { költségvetés }\end{array}$ & $\begin{array}{l}\text { Teljesítési } \\
\text { képesség }\end{array}$ \\
\hline $\begin{array}{l}\text { Az egységes } \\
\text { piac a szabályok } \\
\text { összehangolása, } \\
\text { az elốíások } \\
\text { közelítése és a } \\
\text { jogérvényesités } \\
\text { fokozása révén } \\
\text { megerősödik; a } \\
\text { kereskedelemmel } \\
\text { kizárólag } \\
\text { uniós szinten } \\
\text { foglalkoznak }\end{array}$ & \begin{tabular}{|l|} 
Az öt elnök \\
2015. júniusi \\
jelentésében \\
foglalt elképzelés \\
szerint \\
megvalósul \\
a gazdasági, \\
pénzügyi és \\
költségvetési \\
unió
\end{tabular} & \begin{tabular}{|l|} 
Mint a \\
„Kevesebbet \\
hatékonyabban” \\
forgatókönyvben; \\
a határigazgatás, \\
a menekültügyi \\
politika és a \\
terrorizmus elleni \\
küzdelem terén \\
szisztematikus az \\
együttmüködés
\end{tabular} & \begin{tabular}{|l|} 
Mint a \\
„Kevesebbet \\
hatékonyabban" \\
forgatókönyvben; \\
az EU egységes \\
álláspontot \\
képvisel \\
valamennyi \\
külpolitikai \\
kérdésben; \\
európai védelmi \\
unió jön létre
\end{tabular} & $\begin{array}{l}\text { Jelentősen } \\
\text { korszerüsítve és } \\
\text { növelve, saját } \\
\text { forrásokból } \\
\text { történő } \\
\text { finanszírozással; } \\
\text { az euróövezet } \\
\text { költségvetési } \\
\text { stabilizációs } \\
\text { funkciója } \\
\text { müködik }\end{array}$ & $\begin{array}{l}\text { A döntéshozatal } \\
\text { gyorsabb és az } \\
\text { érvényesités } \\
\text { határozottabb } \\
\text { minden területen; } \\
\text { elszámol- } \\
\text { tathatósági } \\
\text { kérdések } \\
\text { merülnek fel azok } \\
\text { számára, akik } \\
\text { úgy érzik, hogy } \\
\text { az EU túl sok } \\
\text { hatáskört vett el } \\
\text { a tagállamoktól }\end{array}$ \\
\hline
\end{tabular}

Forrás: Fehér Könyv Európa jövőjéről, 2017.

A koronavírus-járvány mindezt alaposan át fogja alakítani, és a krízis elején úgy tünik, hogy a közösségi felelősségvállalás erősödik, azonban ez a tézistervezet lezárásáig nem került elemezhető formába.

Az Európai Unió a világban általánosan csökkenő szabadság és jogállami normák világában keresi a válaszokat annak érdekében, hogy a nyugati szövetségi rendszer európai felén helyreálljon a II. világháborút követő európai jogállami és társadalomfejlődési irány: a liberális demokrácia intézményei ne sérüljenek. A szabadság és a szolidaritás összekapcsolása, melyen az Európai Unió a létrejötte óta dolgozik, mára a biztonság és szabadság kettősével bővült, ez világosan látszik a Fehér Könyvből.

\subsection{A liberalizmus feladata az Európai Unió tagországaiban}

Nemzetközi szinten is kár temetni a liberalizmust; jelenleg az uniós tagországok több mint negyedében liberális vezetésű kormányt találunk, noha gyakori érv a liberálisok ellen, hogy a liberalizmus már minden célkitüzését elérte, amiért küzdött: általános választójog, jogállam, a demokratikus intézményrendszer stabilitása, diszkriminációmentesség és minden értelemben vett jogegyenlőség, az Európai Unió célja pedig, hogy a piacon is érvényesítse a jogállami normákat.

A társadalmi feszültségek a szélsőséges gondolatok és politikai erők táptalajaként szolgálnak. A tolerancia-eszme talán legnagyobb hiányossága is lelepleződik ezzel: nehezen tud a szélsőségekkel szemben fellépni, ez pedig társadalmi és értelmezési 
zavarokat is eredményez. A dolgozat konklúziója elemez egy tanulmányt, amely az oktatással és az erkölcsre való neveléssel foglalkozik, így erre a kihívásra müködőképes választ adhat.

Magyarországon és Lengyelországban más helyzetben van a liberalizmus, mint az Unió többi tagországában. A leginkább szembeötlő különbség az Európai Unió többi tagországához képest, hogy ezek a tagországok a demokráciára hivatkozva - hiszen a választók akaratából kaptak felhatalmazást a kormányzásra - gyengítik és építik le a jogállamot, vagyis elvetik a kettő házasságából született liberális demokráciát. Magyarországon a kormány ezt „,illiberális demokráciának” nevezi. (HFI, 2017.)

A rendszerváltás fóárama liberális értékekkel telt meg, és a jelenlegi útkeresés utáni intézményrendszer-újjáépítés is elképzelhetetlen liberális gondolatok és liberális intézményépítés nélkül. A hatalmi ágak szétválasztása a zsarnokság kialakulását akadályozza.

Ludwig Erhard Jólétet mindenkinek címü, 1957-es írásában nem is tesz igazán különbséget politikai és gazdasági szabadság között: „... mindenfajta piacgazdaság alapja az és az is marad, hogy a verseny szabadságát fenntartsuk. Ez csak ott uralkodik, ahol nem türnek el semmilyen, a szabadság elnyomására törekvö hatalmat, hanem ahol a szabadság, mely egy-egy nép erkölcsi és jogi kódexében rögzül, általánosan kötelezö parancsolattá, sőt a közösség legfőbb értékévé válik." (Erhard, 1957, 1993. p. 95.) E két szabadságjog-típus szorosan összefügg, és az Európai Unió, felismerve ezt, jól körülhatárolta azt a feltételrendszert, amelynek ha megfelel egy tagország, akkor objektív mérce alapján tekinthető szabadnak a társadalom.

\subsubsection{A liberalizmus szükségessége a társadalomszervezésben - a jogállam csorbulása mint közösségi jogsérelem}

A nyugat-európaiak sem kapták örökül a demokráciát. Minden társadalom végigjárta a maga forradalmait, harcait, diktatúrákból egészen a '70-es évekig kijutott, a vasfüggönytől nyugatabbra is. A '49-es fordulat arról szól, hogy a szabad világ vezetői megértették, mi az, amiért nap mint nap meg kell küzdeni. Az ENSZ Alapokmány aláírásával egészen új Európa nyitogatta a szárnyait, ami elvezetett odáig, hogy a jogegyenlőség és az egyenlő méltóság elve biztosított legyen mindenütt. Ahol mégis csorbulnak ezek, ott a hatóságokhoz lehet fordulni kártérítésért és a jogsérelem korrekciójáért. „Rechstatlichkeitet először, a jogállam primátusát, amely alapvetően 
egy magas szintü jogrend létezéséböl következik, alapvetö jogaival, melyet egy Európai Bíróság garantál." (Delors, 1992, 2013. p. 144.)

Az európai játékszabályok elutasítása azt jelenti, hogy egy tagország közelebb lép a zsarnoksághoz, és távolodik a liberális demokráciától. „A három hatalmi ág egy kézben való összpontosulása a zsarnokság." (Tóth, 2016. p. 26.) Amennyiben ez nem valósul meg, közelebb lépünk egy olyan világhoz, ahol a jogérvényesítés korlátozott, és az egyenlő bánásmód elve hiányzik.

A szabadság és felelősségvállalás értékkettőse alapvetően meghatároz egy politikai közösséget. A demokratikus kultúra annak a mély megértését jelenti - és diktatúrák után egy társadalomban nagyon nehéz ezt a fordulatot megtenni -, hogy négyévente nem despotát választanak a polgárok. Nem teljhatalommal ruházzák fel a vezetőiket akkor, amikor demokratikus felhatalmazást adnak az ország vezetésére. A társadalomszervezés felelőssége a liberális demokráciákban arra is kötelezi a mindenkori kormányokat, hogy a rendszer hosszú távú stabilitását előbbre valónak tartsák, mint a saját önös politikai érdekeiket. Ezt a célt egy olyan iskolarendszer képes szolgálni, amely nem a félelemalapú nevelés elvén alapszik.

„,Tudniillik csak az állam jó szervezetétöl függ (ami mindenesetre az emberek hatalmában van) azoknak erőit úgy irányítani egymás ellen, hogy egyik a másikat romboló hatásában feltartsa, vagy ezt megszüntesse: az eredmény aztán az észre nézve úgy jön ki, mintha egyik se léteznék. Így az ember, még ha nem is erkölcsileg jó ember, mégis kényszerül jó polgár lenni. Az államalakitás problémája, akármilyen keményen hangzik is ez, még egy ördögökböl álló népre nézve is megoldható” (Kant, ford. Babits, 2015. p. 27.) A jogállam intézményrendszerének építése ezért kulcsfontosságú, mert a fent említett hosszú távú stabilitás garanciáját jelenti. Azt jelenti, hogy még egy alapvetően rossz szándékú emberekből álló közösség sem tudja tönkretenni az intézményrendszert vagy a társadalmi folyamatok fejlődését. Ebben áll a jó társadalomszervezés és az államépítés felelőssége.

A világban keletkező új kihívások arra is kötelezik az egyes szupranacionális szervezeteket és nemzeti kormányokat, hogy új módokat fejlesszenek ki a kihívások kezelésére. A globalizáció miatt a problémák egy pillanat alatt válnak világszintűvé, és hatékonyan kell rájuk megoldást találni. Az Európai Uniónak erre a lokális cselekvés a válasza. 


\subsection{A globális gondolkodás és lokális cselekvés kivételes szerepe}

Az Európai Unió megerősítése nem önmagáért való cél. Ha a Nyugat nem lép, és a nyugati szövetségi rendszer nem erösödik meg annyira, hogy képes legyen meghatározni a globális élelmiszer-biztonsági standardokat, a világpiac antidemokratikus, emberi méltóságot és alapvető jogokat nem tisztelő hatalmak kezébe kerül.

Mialatt a dereguláció és a jogharmonizáció folyamatai egyszerre zajlottak az egész világon (a GATT-on, később pedig a WTO-n keresztül), valamint az Európai Unióban, előkészített a közösség egy olyan közös piacot, amelyben a fogyasztóvédelem és a piaci szabályozás minőségi árukat követel a termelők részéről, ráadásul a horizontális és vertikális kartelltilalmakon keresztül kezességet vállal a tisztességes piaci versenyért. Ha az Unió nem képes világpolitikai és világgazdasági szerepét tekintve megerősödni, akkor valóban le fogják győzni a feltörekvő piacok, melyeknek a vezetése ellentétes társadalomszervezési célokkal rendelkezik. Az euroatlanti szövetségi rendszer úgy építette ki a piacgazdaságot, hogy közben a jogállam és a demokratikus intézményrendszer megerősítését is célul tüzték ki a társadalomszervezők. A fejlődő világ (mint Kína, India, Brazília, Oroszország, vagy akár Nigéria) növekvő világpiaci ereje mögött olyan államokat találunk, melyek nem tartják fontosnak az emberi jogok érvényesülését, és ahol az emberi méltóság mindenki esetében való érvényesülése nem cél. Ezek azok az országok, amelyek ugyan tagjai az ENSZ-nek, mégsem törekednek az ENSZ Alapokmányban foglaltak betartására és betartatására. Kül- és belpolitikai törekvéseikben - a nemzetgazdaságuk erősödése mellett - olyan elemeket találunk, amelyek alapvetően mennek szembe az emberi jogokkal, a szabadságjogok kiterjesztésének követelményével, nem beszélve az egyenlő méltóság és egyenlő bánásmód elvéről.

Amennyiben a II. világháború után lefektetett béke és biztonság meginog, 70 éves korszak zárul le, és nyílik helyette egy prosperitást kevésbé vagy egyáltalán nem ígérő, gazdasági és politikai értelemben erőtlen kontinens, amely a világ népességéhez mérten is veszít jelentőségéböl: 2060-ra már csak a világ népességének 4\%-át jelentik majd az európaiak. (Fehér könyv Európa jövőjéről, 2017.) 


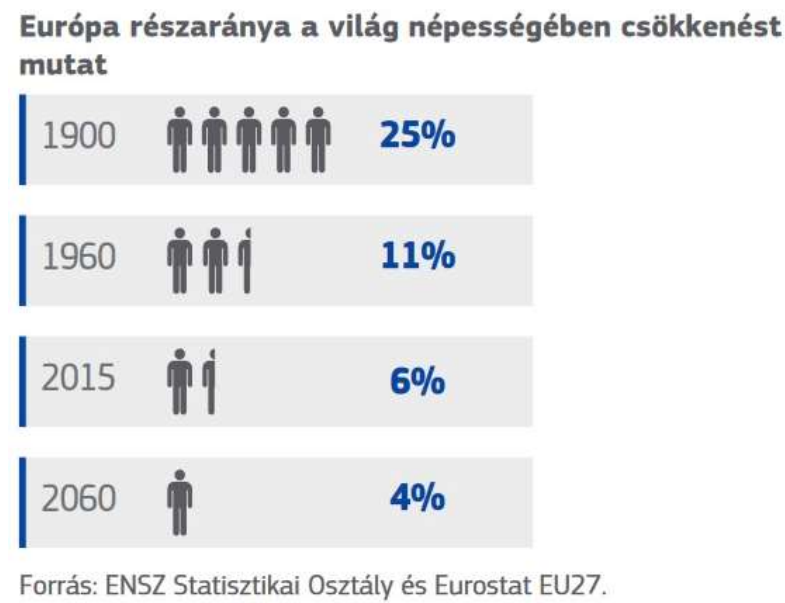

Forrás: ENSZ Statisztikai Osztály és Eurostat EU27.

A liberalizmus gyakorlati képviselőinek globális felelőssége abban áll, hozzájárulnake a '49-ben lefektetett fékek és ellensúlyok megőrzéséhez a világban. Ez nem másról szól, mint hogy mindenkit, aki embernek született, azonos jogok illetnek meg. Ehhez azonban olyan nemzetközi szervezetek és olyan kormányok szükségesek, amelyek ennek a világrendnek a fenntartásában érdekeltek. Az Európai Unió és a liberális demokrácia gyengélkedése elvezethet egy olyan világhoz, amely alapvetően változtatja meg azt a típusú békét, amit Európa és az USA az elmúlt 70 évben képes volt őrizni. (Fehér könyv, 2017.)

Ugyan a gazdaság - úgy tünik - kilábalt a válságból, valamennyi uniós tagország gazdasági növekedése pozitív, a görögök maguk mögött hagyták az államcsőd veszélyét, és lehetőségeikhez mérten stabilizálták nemzetgazdaságukat, az új európai költségvetési ciklus, a Brexittel járó forráskiesés miatt, új bevételi források és a kiadási oldalon szorgalmazott reformok keretében készül. Mégis válságérzete van az embereknek. A külső és a belső politikai kihívások próbára tették az emberek türelmét és az Unió vezetőit is. (Ezen a koronavírus jelentősen változtathat, de jelen dolgozat lezárása a vírus európai megjelenésének első heteire tehető, egyelőre a gazdasági következmények nem felmérhetők.)

A Fehér könyv öt forgatókönyve egyértelműen néz szembe ezekkel a kihívásokkal, és fektet le olyan megoldási javaslatokat, melyek mindegyike müködőképes lehet, a kérdés csupán az, mely forgatókönyv megvalósítására van politikai és közösségi akarat. A közösségi akaratot az unióellenes hangok gyengítik, a populizmus új hullámának képviselői maguk teremtik újra és újra az euroszkepticizmust, melynek keretében a liberális demokrácia és az integráció mélyítésének hívei egyre kisebb demokratikus felhatalmazásra számíthatnak. 
A Fehér könyv és a 2021-27-es költségvetési ciklus előzetes tervei azonban felelős fiskálispolitikai, gazdasági és társadalmi magatartást feltételeznek. Ezek nélkül ugyanis az Unió egésze gyöngül, és világpiaci pozícióvesztése felgyorsul.

\subsection{Az egyéni és közösségi felelősségvállalás megjelenése az Európai Unió következő költségvetési ciklusában}

Az Európai Unió a 2021-27-es költségvetési ciklusra nézve új irányelveket fogalmazott meg. A nettó befizetők terheit saját bevételekkel enyhítené, míg a nettó haszonélvezőket nagyobb társfinanszírozási részarányra kötelezné. A termeléshez köthető támogatások és az agrártámogatások mértéke csökken a legnagyobb mértékben, mert az európai közjavak biztosításához nagyobb költségvetési keretösszegre van szüksége a közösségnek. A közös határvédelem és közös biztonságpolitika, a Horizont 2020 program (föképp a kutatás-fejlesztés és a digitalizáció), valamint a migrációs nyomás azt eredményezik, hogy az Európai Unió financiális kötelezettségei jelentősen emelkednek. Ezeket részeben a kohéziós alapok forrásainak terhére, részben pedig a közös bevételek terhére kívánják megvalósítani. (Andor, 2018.)

Az Európai Unió hosszútávú tervei közt szerepel a társfinanszírozási arányok megváltoztatása. Míg az eddigi gyakorlat szerint 85-15 arányban oszlott meg a kohéziós alapból származó pénzek és a tagország büdzséjét terhelő források összege, ez az arány az új elképzelés értelmében 70-30-ra változik. A bevételi oldal növekedését három forrástól várja az Unió: a vámjellegü bevételekből, a nem újrahasznositható müanyagtermékek megadóztatásából, valamint a széndioxidkvótából. A kohéziós alapokból származó támogatások átalakítása két módon mehet végbe, vagy kevesebb régió részesül támogatásban, vagy magasabb a társfinanszírozás aránya. Törekedni kell a pénzösszeg hatékony felhasználására, minőségi értelemben. (Andor, 2018.)

A mindenkori kormányok feladata az, hogy a társadalom igazodását segítse a globális folyamatokhoz, ez a gondolat szolgáltatja az Európai Unió költségvetési terveinek elvi hátterét. A XXI. század kihívásaira közösségi szinten keresi a választ, ennek elengedhetetlen eleme az európai közjószágok minél jobb minőségü és hatékonyabb biztosítása. E célok - megvalósulásuk esetén - a Közösség hosszú távú stabilitásának garanciájaként szolgálhatnak. 
A 2019. január 17-én 71\%-os többséggel elfogadott Európai parlamenti határozat rögzíti, hogy a jogállamisághoz kötik a fenti változtatásokon kívül az uniós pénzek kifizetését. E lépés az Unió fennállása óta először várja el már meglévő tagországoktól, hogy betartsák a koppenhágai kritériumokat, és további, közös fiskális és/vagy jogi kritériumokat is meghatároz, amelyek egyfelől a jogbiztonságot, másfelől az uniós pénzek elköltésének tisztaságát garantálják.

A jegyzőkönyv ${ }^{21}$ rögzíti, hogy a demokrácia és a jogállami normák tiszteletben tartása alapvetés. A bíróságok függetlensége, a jogegyenlőség, a törvényhozásnak átláthatónak és elszámoltathatónak kell lennie. A méltóság és az alapvető jogok tisztelete, a diszkrimináció tilalma, valamint a kisebbségi jogok védelme alapvetésként fogalmazódik meg az Európai Közösségben. A jogállami normákat, valamint az európai polgárok jogi értelemben vett életminőségét az Európai Unióról szóló szerződés második cikkében taglalja. Ezek a feltételek egyúttal a közösség felvételi kritériumai is.

Kritériumként szabja a független ügyészséget, a meglévő ellenőrző szervekhez való csatlakozást, melyek segítik a közösséget a korrupció és az adóelkerülés visszaszorításában.

Az Unió az alábbi pontokat határozza meg lehetséges hiányosságként, amikért felfüggeszthetik egy adott tagország uniós támogatását, ha

- az uniós költségvetést végrehajtó tagállami hatóság nem müködik megfelelően;

- a pénzügyi ellenőrzést végző tagállami hatóság nem működik megfelelően;

- az uniós költségvetés végrehajtását befolyásolja, hogy a csalások (beleértve az adócsalást), korrupció és az uniós jog egyéb megsértése ügyében nyomozó hatóság nem müködik megfelelően;

- nem megfelelően müködik a hatékony és független bírósági felülvizsgálat;

- a jogosulatlanul kifizetett összegeket nem fizetik vissza;

- az adóelkerülés és adóverseny megelőzése és büntetése nem müködik megfelelően; és

- nincs megfelelő együttmüködés az Európai Csalás Elleni Hivatallal (OLAF), és, amennyiben az adott tagállamra vonatkozik, az Európai Ügyészséggel.

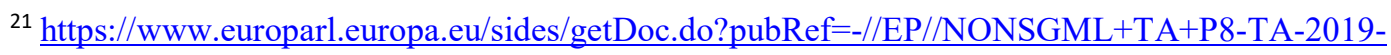
$\underline{0038+0+\mathrm{DOC}+\mathrm{PDF}+\mathrm{V} 0 / / \mathrm{HU}}$ 
Ami a hosszú- és rövidtáv megvalósíthatóságát és célfüggvényeit illeti, hosszú távon a tagországoknak is az az érdekük, hogy az Európai Unió mind gazdasági, mind társadalmi fejlődését tekintve egy stabil pályán mozogjon. Ehhez azonban szükség van a közös politikák megerősítésére és arra is, hogy a 21. század kihívásaira megfelelő közös válaszokat találjon a közösség. A közös játékszabályok betartásának és betartatásának eszköze lehet az új kritériumrendszer, amely a VII. cikkely életbeléptetése előtti figyelmeztetésként is felfogható.

Továbbra is kérdés, hogy az Unió képes-e tenni a liberális demokráciáért, de kétségtelenül keresi az eszközöket arra, hogy a tagországokat minél demokratikusabb és átláthatóbb pénzügyi keretek között tartsa, ezzel egységesítve nem pusztán a fiskális kultúrát, de a jogállami normákat is.

Összességében elmondható, hogy az egész világra nézve igaz a megállapítás: csökkent a szabadság, még a nyugati szövetségi rendszer számos országában is mérhető a jogállami keretek csorbulása, a demokratikus intézményrendszer sérülése, valamint a polgárok politikai és gazdasági szabadságjogainak csökkenése.

Az Európai Unió felismerte történelmi szerepét a gazdasági, politikai és társadalmi kihívások közepette: a 2017-ben megszületett Fehér Könyv megjelenése Európa egyben tartására irányul elsősorban, akár azon az áron is, hogy kevesebb közös politika vagy kevesebb közös kompetencia marad meg az eddigiek közül. Természetesen ahogyan a Könyvet elemző fejezetben is jeleztem - a forgatókönyvek alapesetek, ezeket a képeket bizonyosan árnyalja majd a valóság. Feltételezésem szerint úgy müködnek majd, mint a mikro- vagy makroökonómiai modellek, amelyek bár nem írják le tökéletesen a piac működését, de közelítik azt, és egyszerüsített módon teszik elemezhetővé a gyakorlatot.

Jellemző a kelet-közép-európai régió országaira, hogy az átlagosnál nagyobb arányban csökkent a szabadság, jobban sérültek a jogállami normák, néhány országban még a hatalmi ágak szétválasztásának évszázados hagyománya is veszélybe került. Ez ellen az Európai Unió eddig tehetetlen volt, azonban a 2019. január 17-én hozott Európai parlamenti döntéstől azt várta az európai közösség, hogy nagyobb mozgásteret biztosítson az Unió számára ahhoz, hogy az egyéni és kollektív szabadságjogok garanciáit kikényszerítse az egyes tagországokból.

Ezzel az Unió olyan jogosítványt kívánt teremteni önmaga számára, amely lehet hatékony eszköz a jogállami normákat nem tisztelő tagországokkal szemben. Azok az országok, amelyekkel szemben valóban élni kényszerül majd a közösség a 
forrásmegvonás lehetőségével, jelenleg jó valószínűséggel nem nyernének felvételt az Európai Unióba, amennyiben még a csatlakozás elött állnának, így jogos a közösségi igény, hogy ne részesedjenek az egyébként is fiskálispolitikai és antikorrupciós értelemben homogenizálandó országcsoport megtermelt javaiból.

Egyelöre nehéz választ adni a kérdésre, hogy az Európai Unió ezzel a liberális demokráciáért tett-e, hiszen végső esetben a jogállami normákat elvető tagországok dönthetnek a kilépés mellett, ezzel újabb társadalmakat megfosztva a II. világháborút követő Európa vívmányaitól, azonban ez csak gondolatkísérlet. Minden olyan tényleges lépés, amelyet az Európai Unió jogosan alkalmazhat a csatlakozási feltételeket sem teljesítő tagországokkal szemben a jogállami normák tisztelete és a demokratikus intézményrendszer újjáépítése érdekében, értelmezésemben a liberális demokrácia megőrzésére irányul.

Lényeges elem lehet a fertőző hatás, mert - ahogyan az elmúlt időszakban kirajzolódott - a demokratikus intézményrendszert és jogállami normákat sértő kormányzatok egymástól (is) vett gyakorlatai további tagországokra is átterjedhetnek. A még 2018-ban is tehetetlennek mutatkozó európai közösség - úgy tünik - közelebb került ahhoz, hogy valóban tehessen a liberális demokrácia fennmaradásáért és azért, hogy a tagországok nemzetgazdaságokra lebontva a kevésbé fejlett régiókban is vállaljanak egyéni felelősséget saját fejlődésükért. A gyakorlati megvalósulás további kérdéseket is felvet, de ez nem pusztán terjedelmi korlátokat tekintve feszítené túl e dolgozat kereteit.

A szemünk előtt zajló történelem közbeszólt, így 2027-ig nem tudjuk meg, hogy a „békeidőre” tervezett költségvetési ciklus hogyan működött volna az új szabályozással. A koronavírus-járvány okozta gazdasági-társadalmi válságra az Európai Unió hirtelen kényszerült reagálni. Az EU által 2020. decemberében elfogadott többéves pénzügyi keret 1074,3 milliárd eurót, valamint a „Next Generation $E U^{\prime}$ keretösszeggel (750 milliár euróval) kiegészülve minden eddiginél nagyobb összeget irányzott elő a következő költségvetési ciklus finanszírozására. Bizonyos szakpolitikai területek továbbra is kiemelt jelentőséggel bírnak, így a környezetvédelem és a digitalizáció, valamint a közös agrárpolitika és a kohéziós politika. $^{22}$

\footnotetext{
${ }^{22} \mathrm{https} / / / \mathrm{www} . c o n s i l i u m . e u r o p a . e u / h u / p o l i c i e s /$ the-eu-budget/long-term-eu-budget-2021-2027/\#
} 
A fejezetben tárgyalt jogállami normák kikényszerítését elodázza a közösség, de ahogyan a 2020 év végére megszületett döntések és dokumentumok tartalmazzák: a 27 tagországra kiterjedő válságkezelő csomag életbe lépése a jelen és a jövő generációi számára rendkívül fontosak lesznek abból a szempontból, hogy a kontinens gazdasága képes-e kilábalni a válságból. A jogállami garanciák életbe léptetését a közösség nagyjából másfél-két évvel későbbre halasztotta.

\subsection{A koronavírus-járvány okozta gazdasági-társadalmi károk egyik} szakpolitikai következménye: a lehetséges európai adóharmonizáció Lehetséges-e adóharmonizáció az Európai Unióban, és mi lehet ennek hatása?

Az Európai Unió egyik következő kihívása az adóharmonizáció, különböző tagországok különböző adószabályozása ugyanis torzítja a közös piacot. „Az Európai Unióban nincs minden területre kiterjedö közös adópolitika, és belátható időn belül nem is lesz. Noha az egyes adónemekre az elmúlt évtizedek során bevezettek közös szabályokat, elvárásokat, minimumkulcsokat, ez szinte alig korlátozza a tagállamokat abban, hogy adópolitikájukat a versenyképesség növelésének egyik legföbb fegyvereként vessék be, vagy épp ellenkezöleg, hogy egy elhibázott adópolitikával rontsák le akaratlanul saját nemzetközi versenyképességüket." (Máté et. al, 2014, p. 127.)

A nagyvállalatok sok esetben élveznek kedvezőbb adókulcsot, mint versenytársaik, a szabályozás ilyen módon igazságtalan, mert a nagy adóerő-képességgel rendelkező cégek megnyeréséért folytatott lokális és nemzetközi verseny egy lényegében igazságtalan adórendszert eredményez, amely méltatlanul juttatja elönyös helyzetbe az óriásvállalatokat. Ez a gyakorlat szembemegy azzal az elmélettel, amelyet az Európai Unió alapvetésként kezel a versenypolitikájában. ${ }^{23}$ „A gazdaságpolitikai harmonizáció egyik kulcsterülete az adóharmonizáció, ami a négy deklarált szabadságjog egyik alapfeltétele. Az adók harmonizálásának az áruk és szolgáltatások, a munka és a tőke szabad áramlásának következtében nagy szerep jut, hiszen olyan gazdaságpolitikai eszközröl van szó, amely jelentös versenytorzitást válthat ki." (Halmosi, 2004. p. 19.) A horizontális és vertikális trösztökbe tömörülés tilalma például az egyik legerősebb szabály a közös piacon, amely a verseny torzítását

\footnotetext{
${ }^{23}$ https://www.bruegel.org/2020/11/a-european-common-taxspace/?fbclid=IwAR0d2kXA6LLPkbjna6L9BQ3WVNhqdw S2glow2zzQ1gYa7UwOhJPpvGIIX0
} 
hivatott akadályozni, nehéz így egy olyan adópolitika mellett érvelni, amely alapjaiban veti el az egyenlő bánásmód elvét az egyes cégek között, és bizonyítottan piactorzító hatással bír. ${ }^{24}$

A járványhelyzet most újra kinyitotta azokat a kérdéseket, amelyek meghatározzák az Európai Unió gazdaságstratégiai tervezését a következő évtizedekben. Ennek része a vita a szociális egyenlőtlenségek kezeléséről, a gazdaság egyes régióinak és a tagországok nemzetgazdaságainak újraindításáért vívott küzdelem. Ezekre a kihívásokra a tagországok feltehetően megszorító intézkedésekkel válaszolnak majd, minden valószínűség szerint új utakat keresnek a válságkezelésre. Az új utak keresése tisztán kirajzolódik a 2021-27-es költségvetési ciklus vázlatában, és az arról szóló vitákban is, hogy az Unió saját bevételeinek tervezésekor a gazdaság mely területeiről származhatnak majd ezek a bevételek. (Andor, 2018.) Az Európai Bizottság már egy évtizede is arról értekezett, hogy a „zöld adók” bevezetése a kívánatos, nem pedig a jövedelemadók vagy a fogyasztási adók. Ilyen modellben az energiafogyasztás adóztatása a fenntarthatóság célját is szolgálja. (Máté et. al, 2014.)

A lehetséges adóreformot először az európai zöldek és a szociáldemokraták vetették fel a közös európai piacon, a másik két eszmerendszer képviselői csak később csatlakoztak, de mára több liberális és kereszténydemokrata sorakozik fel a gondolat mögött, hogy nem pusztán célszerü igazságosabbá tenni az adórendszert, de hosszú távon a közösség gazdasági érdekei is ezt diktálják. Abban is egyetértés felé halad az európai politikai közeg, hogy szükség van egy egységes adórendszerre, amely a fiskális unió egyik alapja lehet. Utóbbi jelen pillanatban jó valószínüséggel létrejön majd, de nem mindegy, milyen módon szerveződik meg. ${ }^{25}$

Európának sok fejtörést okoz a társasági nyereségadó-verseny. Lehetséges megoldás, hogy az Unió közös minimum-adókulcsot határoz meg, amely elejét venné az egyes tagországok, települések és régiók versenyének a nagyvállalatokért, amelyek egyébként is sokat profitálnak a piaci müködésükből, az állítás ilyen értelemben az, hogy nincs szükségük az adófizetők pénzéböl olyan különleges kedvezményekre, amely sok tekintetben jogtalan előnyhöz juttatja öket.

\footnotetext{
${ }^{24}$ https://eur-lex.europa.eu/legal-content/HU/TXT/PDF/?uri=CELEX:52011XC0114(04)\&from=ES

${ }^{25} \mathrm{https} / / /$ www.bruegel.org/2020/11/a-european-common-taxspace/?fbclid=IwAROd2kXA6LLPkbjna6L9BQ3WVNhqdw S2glow2zzQ1gYa7UwOhJPpvGIIXO
} 
Az ÁFA-reform több mint húsz éve képezi viták tárgyát az Európai Unióban, és úgy tünik, hogy ezek a viták most újra fontossá válnak a közösség tagjai számára.

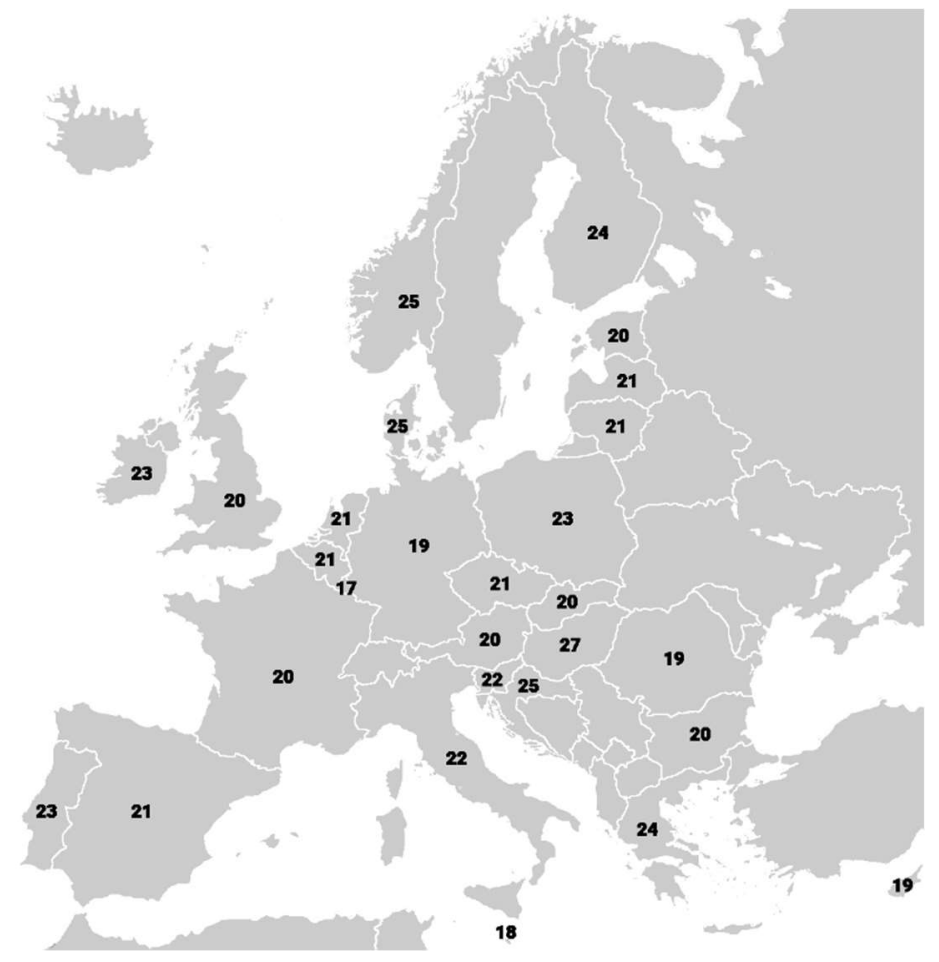

Egyes ÁFA-kulcsok az Európai Unió tagországaiban. Forrás: az Európai Bizottság 2020. január 1-jei jelentése $\mathrm{e}^{26}$

Az ÁFA hagyományosan egy olyan adónem, amely nagyobb arányban terheli a szegényebb társadalmi csoportokat, részben ennek ellensúlyozásaként vezetnek be progresszív jövedelemadózási rendszereket, ha a társadalomszervezési alapelvek az adott országban a szociális igazságosságot is szem előtt tartják, mert részben ki tudja egyenlíteni a fogyasztási adókból eredő egyenlőtlenségeket, amelyek egyéb intézkedések nélkül tovább növelik a szociális igazságtalanságokat.

26

https://ec.europa.eu/taxation customs/sites/taxation/files/resources/documents/taxation/vat/how vat works/rates/vat rates en.pdf?fbclid=IwAR2pYu onTiqAAm zjMiPSna0a00 pAz68iSsgZEVZbu4 ryeWeCKAP ktkA 


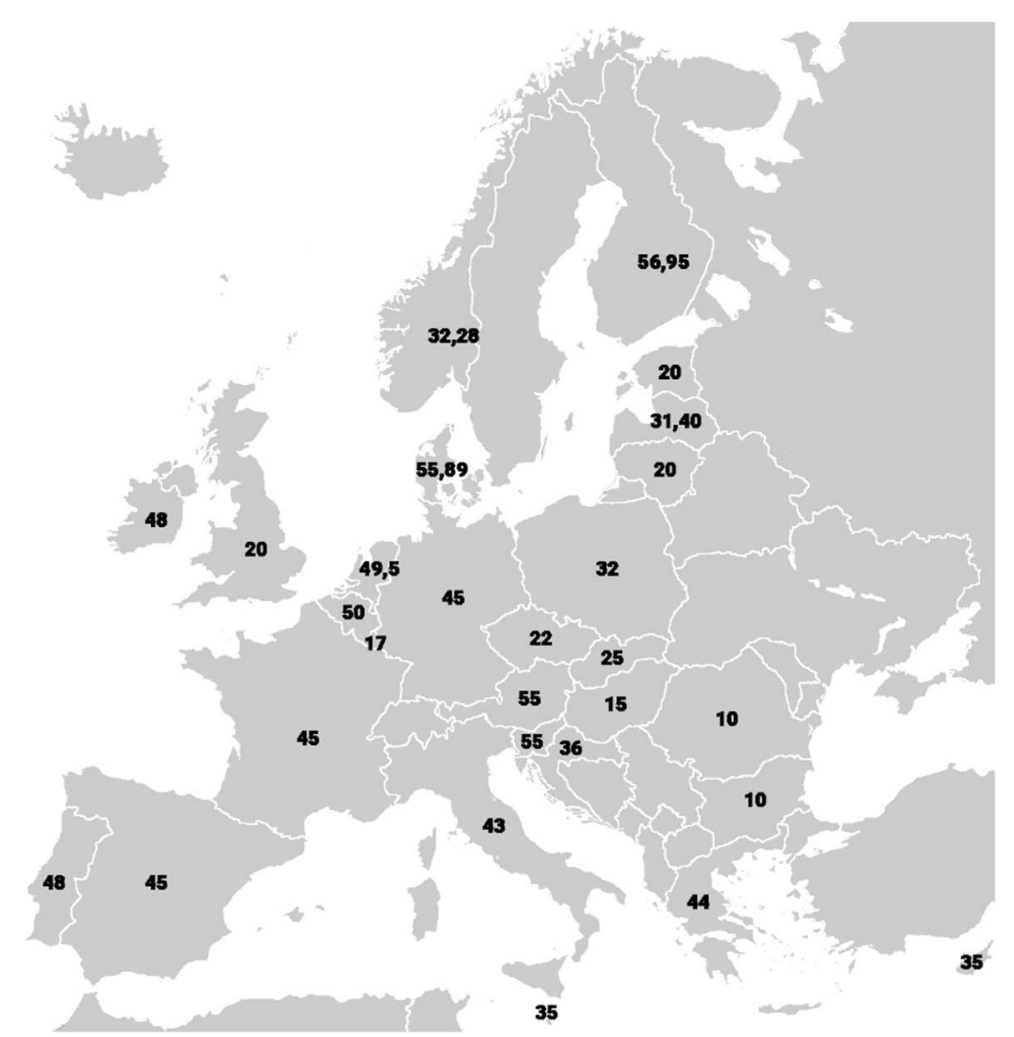

Az egyes uniós tagországok személyi jövedelemadó-kulcsai. Forrás: KPMG ${ }^{27}$

Az egyes tagországok közti adóverseny visszaszorítása meghatározhatja a következő évek gazdaságstratégiai tervezési vitáit. Kérdés, hogy Európa miért nem cselekszik hasonlóan, mint az USA, miért versengenek a lokális és a nemzetgazdaságok a különböző vállalatokért, ezzel közösségi szinten jólétveszteséget okozva. A közös piacon az adóverseny nem fair. A közös piacon érdemes meghatározni egy minimum adókulcsot, ami alá nem mehet senki. Sokkal igazságosabb így az adórendszer, az egész közösségre nézve pedig a potenciálisan elérhető jólétnövekmény is magasabb.

${ }^{27}$ https://home.kpmg/xx/en/home/services/tax/tax-tools-and-resources/tax-rates-online/individualincome-tax-ratestable.html?fbclid=IwAR2ksDsm076ypg2NKZ0QHDZ5mGaSLPGy MAYwa8hMmncAAoLbTQGLVGHAM g 


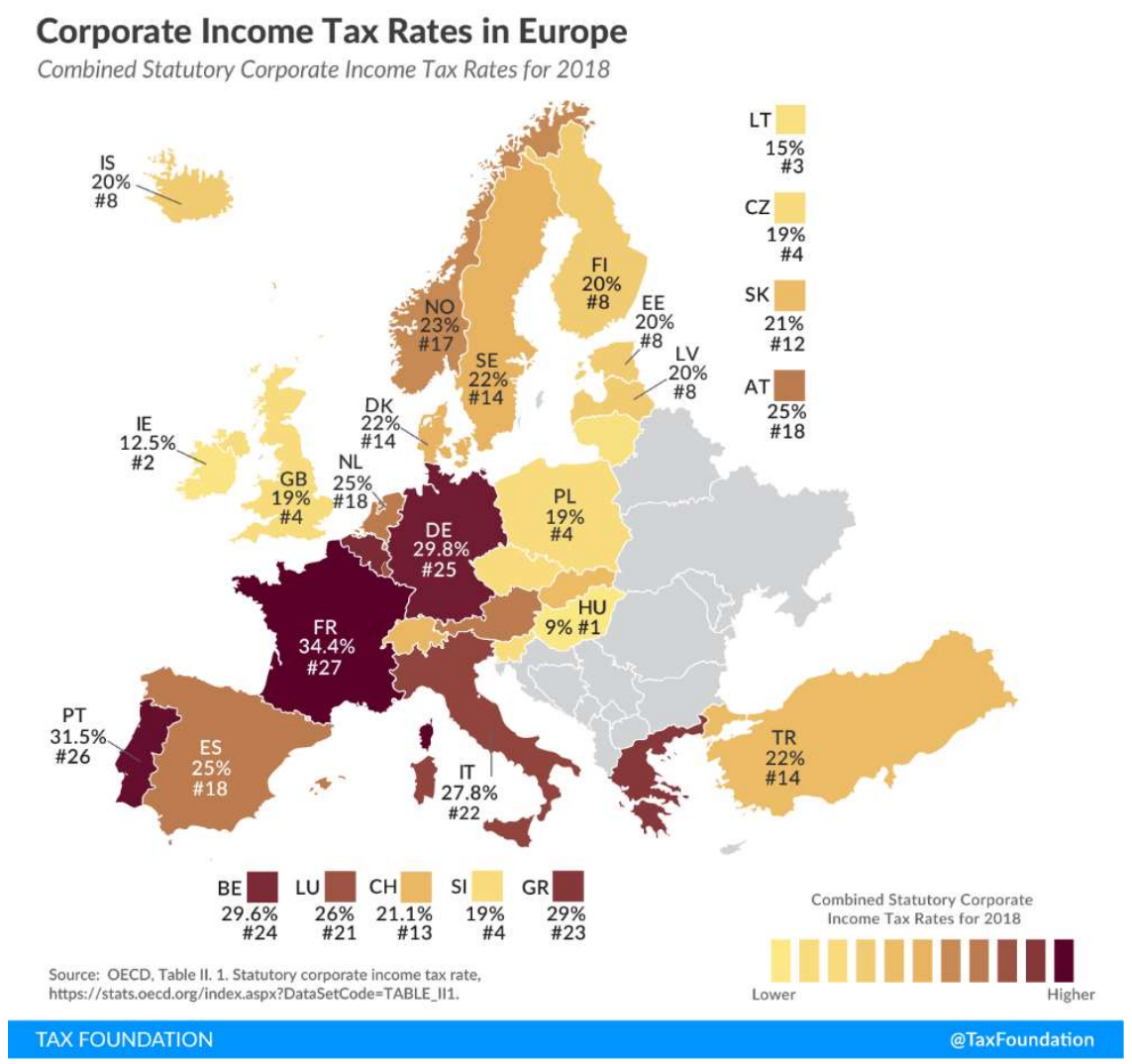

Az egyes uniós tagországok társasági nyereségadókulcsai. Forrás: OECD

A globális adóverseny több tekintetben jólétveszteséggel jár, és ugyan rövidtávon könyvelnek el vállalatok veszteséget, amikor nagyobb adókulcsot határoznak meg számukra, a hosszútávú előnyök és a globális gazdaságstratégiai tervezés szempontjából egy stabilabb és igazságosabb rendszer felé irányítja a gazdaságot. ${ }^{28}$ Elsősorban azok a nemzetgazdaságok veszítenek majd a pozíciójukból, amelyek nagy exporttöbblettel rendelkeznek (mint Németország), de ebben a rendszerben jelenleg rendkívüli igazságtalanságok rejlenek. Hosszú távon a globális gondolkodás vezetheti el a közösséget a közös célok eléréséhez, nem pedig az, hogy egyes uniós tagországok védelmezik a saját nemzetgazdaságukat, és fenntartják privilegizált helyzetüket.

A klímaváltozással, a digitális szektorral, a vállalatok és a tőkejövedelmek adózásával kapcsolatosan az Európai Bizottság előző elnöke tett már egy javaslatot, azonban a cselekvés elmaradt. A jelenlegi bizottsági elnök és az adóbiztos ehhez képest teljes mellszélességgel támogatják a javaslatot, és készek tenni azért, hogy megvalósuljon a

${ }^{28}$ https://www.bruegel.org/2020/11/a-european-common-tax-
space/?fbclid=IwAR0d2kXA6LLPkbjna6L9BQ3WVNhqdw S2glow2zzQ1gYa7UwOhJPpvGIIX0 
konszenzus. Ez a stratégiai irányvonal a Horizont 2020 programból is jól kirajzolódik. (Andor, 2018.)

A 116-os cikk ${ }^{29}$ megengedi ez ügyben a többségi szavazást a konszenzusos döntés helyett. Különös, hogy az Európai Unió a 116-os cikket eddig nem tudta vagy nem akarta komolyan venni és alkalmazni, holott ez a paragrafus meghatározza a közös piac torzításának visszaszorítását. Amint ezt a cikket alkalmazni kezdi a közösség, a vita elmozdulhat a holtpontról az európai adóügyi együttmüködésért tett lépések érdekében. Nem pusztán a társasági nyereségadóval, de szakértők szerint az arbitrázsjövedelmek megadóztatásával is érdemes foglalkozni, vagy legalább vitára bocsátani. 30

Európának további, közeli és távoli jövőjét meghatározó vita a pénzmosás és egyéb gazdasági büncselekmények elleni fellépés hatékonysága. „Az adórendszerek különbözösége egyrészt megnehezitheti ezt a mozgást, másrészt lehetőséget adhat az adóelkerülésre és az adócsalásra is." (Ambrus, 2017. p. 615.) Az Európai Pénzügyi Hírszerzés és az Európai Pénzügyi Rendőrség felállítása kulcskérdés abból a szempontból, hogy sikerül-e végül a közös piacon létrehozni egy rendszert, amely a gazdasági büncselekmények visszaszorítását és az adórendszerek hosszútávú igazságosságát egyszerre képes megvalósítani. Ehhez szükség van közös pénzügyi felügyeletre, intézményi felelősségre, és arra, hogy az Unió tagországai harmonizálni tudják a szabályrendszereiket. A cél elérése erőszakszervezetek megerősítésével és létrehozásával sikerülhet, ilyenek az európai ügyészség és a rendőrség. Nehéz ezt úgy megvalósítani, hogy az Europol nagyjából huszadannyi pénzből gazdálkodik, mint az FBI. A bünüldözés területén az Uniónak érdemes és kell is tovább erősödnie.

Jelen pillanatban az Unió a gazdasági büncselekmények visszaszorításában erőtlennek mutatkozik, versenypolitikájában pedig olyan hiányosság rejtőzik, amely hosszú távon jólétveszteséggel jár. A nagyvállalatok jó része nagyobb adóterhet is elbír, ugyanakkor a középosztály adóterhei számos tagországban lennének csökkenthetők, ha a társasági nyereségadó-kulcs minimumszintjének meghatározásával véget vetne az Unió az adóversenynek, amely nem pusztán a piacot torzítja, de hosszú távon kisebb jólétet, az elosztási mechanizmusokban pedig igazságtalanságokat okoz.

\footnotetext{
${ }^{29} \mathrm{https}$ ://eur-lex.europa.eu/legal-content/HU/TXT/HTML/?uri=CELEX:12016E116\&from=EN

${ }^{30} \mathrm{https://www.bruegel.org/2020/11/a-european-common-tax-}$ space/?fbclid=IwAROd2kXA6LLPkbjna6L9BQ3WVNhqdw S2glow2zzQ1gYa7UwOhJPpvGIIXO
} 
Ha az Unió a jogállamisági kritériumokkal az egyes tagországok társadalmainak jogai fölötti, az adóharmonizáció és a gazdasági büncselekmények visszaszorítására létrehozott erőszakszervezetek megerősítésével pedig a piaci igazságosság fölötti őrködést választja, akkor egy tisztább piacot, igazságosabb gazdaságot hozhat létre. Az adóharmonizáció eredményezheti azt, hogy a nagyvállalatok adókulcsainak viszonylagos egységes képe az egyes tagországok számára lehetőséget biztosít majd arra, hogy a munkavállalók és kisvállalatok adókulcsait csökkentse, ezzel pedig a középosztály túladóztatásának problémája is kiküszöbölhető.

\section{Konklúzió}

A világban keletkezett új kihívásokra a három történelmi eszmerendszer keretein belül akkor lehet jól meghatározott értékvilághoz igazodva válaszokat találni, ha e három eszmerendszer megújul. Jelen dolgozatban a liberalizmus megújulási lehetőségeit és előző eszmetörténeti korszakait vizsgáltam, gazdaságstratégiai tervezési és társadalomszervezési ajánlat tekintetében.

$\mathrm{Az}$ eszmerendszer történetének négyes tagolását tartom célszerünek, a klasszikus liberalizmust, a XIX. századi liberalizmust, a - későn kezdődött és több eszmetörténeti alfejezetre bomló - XX. századi liberalizmust, valamint az újliberalizmust különböztetem meg egymástól.

Az újliberalizmus a - dolgozat felfogása szerint - jelenleg zajló eszmetörténeti fordulópont miatt egyelöre pontos definícióra vár. Ugyanakkor már az 1938-as Lippmann-konferencián kirajzolódott egy szociálliberális irány, melyet nevezhetünk újliberalizmusnak, és amely a később új gazdaságstratégiai tervezői korszakot megalapozó ordoliberalizmussal rokon.

A dolgozatban választ kívántam adni az általam felállított két hipotézisre, valamint szeretnék hozzájárulni az egyelőre nyugvópontra nem jutott liberalizmusvitához. Fontos megállapítani, hogy a liberális eszmerendszer elméleti és gyakorlati képviselői gyakorta követték el azt a hibát, hogy nem definiálták önmagukat megfelelő pontossággal, emiatt viszont jelen dolgozat szerzőjeként több esetben is a definícióalkotást és a konkrétumok megfogalmazását tartottam fontosnak. Ugyanúgy igaz ez a klasszikus liberalizmusra, a XIX. századi liberalizmusra, a XX. századi liberalizmusra, a neoliberalizmusra és az ordoliberalizmusra, mint az általam újliberalizmusnak nevezett irányra. 
A klasszikus liberalizmus képviselöi nem a piacra értették az állami beavatkozás tilalmának axiómáját, hanem az emberek magánéletébe, magánszerződéseibe, jogaiba. Szigorúan véve a jogállami normák keretének felvázolása is beavatkozás - emiatt nem anarchiáról beszélünk -, de ez a szabályozás elvezet a polgárok jogainak és méltóságának egyenlőségéhez. A klasszikus liberalizmus korszakában az emberi méltóság kérdésköre nem ezzel a szókapcsolattal jelenik meg, de amikor Adam Smith vagy John Locke a munkavállalók nyomorának felszámolásáról beszél, vagy a tömegek kilátástalansága elleni fellépésről, voltaképpen az esélyegyenlőség és a gazdasági életben is szerveződő civil szervezetek mellett érvelnek. Ez vezetett el a XIX. században a munkavállalói érdekképviseletekhez, így a dolgozat amellett is szeretne érvelni, hogy a klasszikus liberalizmus hozzájárult a szociáldemokrácia fejlődéséhez is a XIX. században, bár a két korszakot nem szabad összemosni.

A XIX. századi liberalizmus is alapvetően az egyéni és a kollektív szabadságjogok kiterjesztéséről szólt, ugyanakkor a piac - ahol már akkor is müködött monopóliumokat, kartelleket, nagyvállalkozókat és önmagukat nagyon szerényen ellátni képes munkavállalókat eredményezett. Ezek miatt a társadalmi kihívások miatt a XX. század első felében a liberálisok érezték, hogy a piac mindenhatóságát hirdetni nem lehetséges, mert éppen a széles tömegek nyomora világított rá: a szabályozatlan piac voltaképp alapvető jogokat vitat el millióktól.

A neoliberalizmust megteremtő 1938-as Lippmann-konferencián éppen emiatt volt nagy vita a liberális teoretikusok közt: vajon az eszmerendszer válságát a klasszikus liberális elvekhez való mindenáron ragaszkodás, vagy ezek végletes elárulása okozza a liberalizmus elméleti és gyakorlati válaszképtelenségét a fennálló problémákra. A nagy gazdasági világválság évtizedének végén történik ez, egy évvel azelőtt, hogy a III. Birodalom lerohanta volna Lengyelországot, ezzel végérvényesen átalakítva az egész világot. A II. világháború rávilágított arra, mi történik egy olyan világban, amely teljes egészében elvitat egyéni és kollektív szabadságjogokat társadalmi csoportoktól - a haláltáborokba és munkatáborokba küldött emberektől még az élethez való jogukat is.

Ezeket a borzalmakat követően lépnek színre az ordoliberálisok a II. világháború utáni Nyugat-Németországban, és igyekeznek „meggyógyitani a társadalmat” (mint Wilhelm Röpke), valamint olyan költségvetési politikát folytatni (Ludwig Erhardt nyomán), amely a piaci folyamatoknak a hadigazdaságot és a fasiszta diktatúrát követő 
újjáélesztésénél az emberi méltóság és a piaci folyamatokba bekapcsolódók jogainak kőbe vésésével kezdődik. Itt azonban nem áll meg.

Ugyan a gazdaságstratégiai tervező a teljes foglalkoztatottságot - mint az erőforrások maximális kihasználását - célként tűzte ki, tisztában volt azzal, hogy az idősek és a betegek (vagy akár a kisgyermekes édesanyák) időlegesen vagy végérvényesen kiszorulnak a munkapiacról. Ez Ludwig Erhardt és társai szemében kötelezettségeket ró az államra, mert úgy látják, egy ember méltósága és alapvető jogai nem sérülhetnek azért, mert önállóan nem tud jövedelmet termelni.

Az 1938-as liberalizmusvita lényege, hogy annak a csoportnak is igaza volt, amelyik azt képviselte, hogy a klasszikus liberális elvekhez való végletes ragaszkodás vezetett az eszmerendszer válságához, és azoknak is igaza volt, akik azt állították: a klasszikus liberalizmus mind nagyobb elárulása miatt került krízisbe a liberalizmus. A piac kizárólag piackompatibilis állami beavatkozásokkal való szabályozása fontos liberális alapelv. Egy másik liberális alapelv, hogy az emberi méltóság mindenkit megillet, és az alapvető jogok mindenki számára gyakorolhatók kell legyenek.

A kérdésre, hogy vajon a piaci szabadságjogok vagy a társadalom minden tagját megillető méltóság fontosabb érték-e, különböző válaszok adhatók.

A Reagan-Thatcher páros alkotta neokonzervatív-neoliberális „házasságkötés” a '70es évek végétől kezdődően egy olyan világot teremtett, amelyben a piaci folyamatok elsődlegessége volt hangsúlyos. Mindeközben a szegényebb rétegek morális alsóbbrendüségének hangoztatása távol esett a liberalizmus alapjaitól, de bármely ezeken nyugvó elvtől is. A társadalmi szakadékok elmélyülése olyan világot teremtett, amelyben a rosszabb körülmények közt élök sok esetben még az alapvető szabadságjogaikkal sem élhettek.

Az ordoliberalizmus abban különbözik a neoliberalizmustól, hogy az emberi méltóság mindenekfölött való mivoltából vezeti le az elveit (ez meglátszik az 1949-es német alaptörvényben, amely azóta is tartja magát, melynek első mondata: „az emberi méltóság mindenekfölött való és elidegenithetetlen"). Ez azonban arra kötelezte képviselőit, hogy rendszerszintü válaszokat adjanak a szegénység teremtette esélyegyenlőség hiányára. A neoliberalizmus ezt nem tette meg, ennek következményei pedig már a '90-es években is jól látszottak. A 2008-as világválság ugyan önmagában még nem jó érv a neoliberalizmus válságára, még egyértelművé tette, hogy a neoliberális gazdaságpolitika hegemóniájának vége. 
Az ordoliberalizmus nem pusztán az emberi méltóság középpontba állítása miatt vált kutatásom középpontjává, hanem azért, mert úgy vélem, az eszmetörténeti korszakok közül ez állt a legközelebb a klasszikus liberális elvek gyakorlatban való megvalósulásához.

A liberálisok feladata az, hogy egy sok tekintetben eltorzult - és a liberalizmus utolsó eszmetörténeti korszakában teremtett - értékvilág után újragondolják a liberalizmust. A neoliberalizmus milliók számára csak reménytelenséget vagy újratermelt szegénységet hozott, mialatt másoknak a korlátlan felemelkedés és lehetőségek világát teremtette meg, mindeközben még a közösségek sziluettjeit is elmosta. Ebben a folyamatban kulcsszerep jut az egyén és a közösség újbóli összekötésének. Az egyéni és kollektív szabadságjogoknak, a társadalmi csoportoknak. Érdemes a tolerancia szó helyett az elfogadást használni és irányelvként tekinteni. A türelem kifejezés helyett az integrációt, a békés egymás mellett élés helyett a másik ember és a jogrendszer tiszteletét.

Fontos leszögezni, hogy egy ilyen világban a piacgazdaság nem vadlovak vágtája a mezőn. A piacgazdaságot a liberálisok feladata derbivé szelídíteni, ahol mindenki akkor indulhat, amikor eldördült a startpisztoly, és ahol a bírák - a jogállami normák, a gazdasági versenyhivatalok, a versenyszabályozás - kezeskednek a tisztességtelen piaci magatartás kiszüréséért.

A XX. század második felében egyéni felelősségvállalást és gazdasági fellendülést hozó eszmetörténeti szakasz a rendszerváltás előkészítésében és lefolytatásában is nagy szerepet játszott, azonban társadalmi szakadékokat és szolidaritáshiányos környezetet teremtett. E kettő egyvelege nem szolgálja a társadalomfejlődést. A neoliberalizmus válaszképtelennek mutatkozott mind a nemzetgazdasági, mind a világgazdasági kihívásokra, amelyek a XXI. században keletkeztek, mint a szegénység ördögi köre (Nurkse, 1953.), az esélyegyenlőség hiánya. Ennek a válaszképtelenségnek egyenes következménye, hogy a neoliberalizmus korszaka lezárul.

Egy másik kérdés, amivel foglalkozni kell, a neoliberalizmus társadalomszervezési ajánlata, és annak válaszképtelensége az új globális kihívásokra, melyek kétségkívül szintet léptek az elmúlt két évtizedben. A nemzetbiztonsági kockázatot jelentő terrorizmus, a fegyveres konfliktusokból és klímaváltozásból eredő migráció, valamint a populisták ezekre adott válasza, a szabadság és a biztonság szembeállítása mind e kérdéskörbe tartozó jelenségek. Az európai közösségben - ahogyan a dolgozat utolsó, 
jelenkori gyakorlatot érintő fejezetében megmutatkozik - ez a kettő nem hogy szemben áll egymással, hanem úgy teremtik kölcsönösen egymást, ahogyan a szabadság és a felelősségvállalás.

Itt érkezem a dolgozat első hipotéziséhez, miszerint a liberális eszmerendszer nem bukásához, hanem eszmetörténeti fordulópontjához érkezett. Amennyiben az eszmerendszer jelenleg megfogalmazott tartalma - úgy gazdaságstratégiai, mint társadalomszervezési kérdésekben - szolgálja a társadalomfejlődést, akkor a liberalizmus új korszakot nyithat, és megújult formában létezhet tovább. Csak abban az esetben lenne kijelenthető, hogy egy eszmerendszer a bukásához érkezett, ha képtelen lenne olyan ajánlattal előállni a társadalom számára, ami releváns választ ad a fennálló kihívásokra. Míg a neoliberalizmus a fent sorolt hiányosságok miatt válaszképtelenné vált a felmerülő kihívásokra, addig az ordoliberalizmusban mind a két feltevésre adott pozitív válasz megtalálható.

\section{Hipotézisvizsgálat}

Dolgozatom hipotézisei az alábbiak voltak:

1) A neoliberalizmus korszaka lezárult, egy új eszmetörténeti korszak veszi kezdetét a liberális eszmerendszer keretein belül.

2) A liberális eszmerendszer keretein belül létezik olyan gazdaságstratégiai tervezési irány, amely releváns válaszokat ad a jelenkor kihívásaira.

Amennyiben felvázolható olyan ajánlat a liberális eszmerendszer keretein belül, amely releváns válaszokat ad a jelenkor kihívásaira, úgy a 2.) számú hipotézis elfogadható. A 2.) számú hipotézis az ordoliberalizmus elemzésén keresztül fogadható el. A liberalizmus e XX. századi leágazása nem pusztán sikeresen küzdött meg a klasszikus liberális elvek gyakorlatban való megvalósításáért, de a II. világháborút követően egy olyan gazdasági-társadalmi rendet valósított meg, amely minden korábbinál nagyobb volumenű gazdasági növekedést ért el, miközben a társadalmi igazságtalanságokat is kezelte.

A 2.) számú hipotézist a világgazdasági, valamint a társadalmi folyamatok igazolják. A klasszikus liberalizmus képviselői közül Adam Smith tézise a társadalmak szintjén is értelmezhető: amennyiben egy közösségnek hátrahagyott tagjai vannak, az a közösség összhasznát csökkenti. Ennek gyakorlati megvalósulását leginkább a dolgozat 5. fejezetében tárgyalt, Európai Uniós gazdasági és társadalmi folyamatok 
kérdéskörében elemzem. A közösség a globális partnerség egy kontinens-szintü változatát valósítja meg, olyan módon, hogy betartja azt a klasszikus liberális elvet, hogy az egyéneknek - jelen esetben a tagországoknak - felelősséget kell vállalniuk önmagukért és saját fejlődésükért. Ugyanakkor közösségi szinten valósul meg az esélyegyenlőségért való küzdelem elve: a kohéziós és regionális alapok arról szólnak, hogy azok, akiknek segítségre van szükségük az önfejlesztéshez, megkaphatják a közösségtöl.

A 2.) számú hipotézist továbbá az ordoliberalizmus gazdaságstratégiai és társadalomszervezési elemzése igazolja. A piackompatibilis beavatkozások azt segítik, hogy a gazdaság szereplői a piacgazdaság feltételei mellett, ugyanakkor egy rendezett keretrendszerben végezhetik tevékenységüket. A tisztességtelen piaci magatartás kiszürése, a hátrányból indulók állami segítése, a központi fiskális és monetáris fegyelem őrzése azt garantálják, hogy - szemben a szabályozatlan piaccal - a piaci kudarcok lehető legjobb szürése mellett nem a „szabad-”, hanem a „tökéletes verseny” gyakorlati formája adja a gazdaság alapját.

A 2.) számú hipotézist igazoló tételek alapján elfogadható az 1.) számú hipotézis.

Az ordoliberalizmus négy évtizedes korszaka empirikus kutatásként is felfogható, amely bizonyítja, hogy a klasszikus liberális elvek gyakorlatban való megvalósulását lehet segíteni, jó válaszokat adni az olyan kihívásokra, mint a kirekesztés által teremtett morális válság, a társadalmi szakadékok, a munkanélküliség és az infláció együttesen jelenlévő magas rátája, vagy az elesett társadalmi csoportok jogérvényesítő képességének szociális helyzetből fakadó korlátozottsága. A XXI. századi liberális irány nem homogén. A felsorolt kihívásokra különböző válaszok adható, a dolgozat azonban azért született, hogy felvázoljon egy lehetséges irányt, ami az ordoliberalizmus sikereire való hivatkozással vitaanyagként szolgálhat.

Az értekezés két ponttal tartozik még az olvasónak: annak bizonyításával, hogy az erényesség tanítható, és található olyan módszer, amiben a modern kor embere ezeket úgy tudja elsajátítani, hogy azután a mindennapjai szerves részeként, észrevétlenül viselkedik erényesen. A nagy intézményrendszerek felépítése mellett az értékrend és az értékrend sikeres átadásának képessége is szükséges a XXI. századi kihívásokra adott válaszok megtalálásához.

A dolgozat nem pusztán terjedelmi korlátokból eredően nem tud részletesen kitérni pedagógiai módszerek elemzésére, azonban egyetlen olyan esetet említenék, amelyben 
napjaink gyermekei közelebb kerültek az erényes viselkedéshez, egy empirikus kutatás alapján.

Új politikai generáció nőtt fel az elmúlt három évtizedben, amely kamaszkorától kezdve, nagy számban olvasta a Harry Pottert. Ez a nemzedék már gyerekkorában találkozott az ókori görög filozófia alaperényeivel, egy olyan évszázad végén, amelyben két világháború is megmutatta, mit okoz egy társadalomban a hiányuk. Szerethető gyerekekként ismerte meg ezeket a több ezer éves értékeket. A bátorság képében Harry Pottert, a bölcsesség szerepében Hermione Grangert találjuk, Ron Wisley a mértékletesség szimbóluma. A regényeknek köszönhetően pedig azzal is szembesülhetett a fiatal olvasó, hogy e három fölött ott áll az igazságosság, az iskolaigazgató, Albus Dumbledore. Az értékek szövetsége nélkül nem érhetik el céljaikat: négyen együtt alkotnak egységet.

A tanulmány, amely a J. K. Rowling műveiből tanulható erényességet vizsgálja, már a címében is azt állítja, Harry Potter legnagyobb varázslata: csökkenti az elöitéleteket (Vezzali et al, 2015.) kérdőíves módszerrel dolgozik, három korcsoportot vizsgál. Az előfeltevés, mely szerint a Harry Potter csökkenti az elöítéleteket, igaznak bizonyult. Első körben általános iskolásokat, később középiskolásokat és egyetemistákat vizsgáltak. Arról kérdezték őket a fejezetek elolvasása után, amelyekben megjelenik az előítélet, hogyan érzik magukat. Ezt semleges fejezetekkel is megtették. A középiskolásokat és az egyetemistákat is arról kérdezték, hogy az egyes szereplőkkel kapcsolatosan milyen érzéseik vannak. A tanulmány állítása az eredmények fényében, hogy azok, akik olvasták a Harry Pottert, ,jobb emberré” váltak. Ez alatt a tanulmány szerzői - az alkalmazott pszichológia egyetemi oktatói - azt értik, hogy az egykori kis olvasók olyan felnőttekké váltak, akik toleránsabbak a kisebbségekkel szemben, és empátiával viseltetnek azokkal az emberekkel szemben, akiket a társadalom megbélyegez.

A könyv felveti a származás alapú megkülönböztetéstől való távolmaradást (Hermione mugli - vagyis nem varázsló - származása miatt Malfoy csúfolja, azonban a többiek a védelmére kelnek). Ron Wisley nagyon szegény családból származik, Neville Longbottom ügyetlen és esetlen, Hagrid kilóg a sorból, nem pusztán óriás termetével, de azzal is, hogy ugyan a Roxfortban tanít, de nem varázsolhat. Harry Potter maga is kisebbségi létbe kényszerül azzal, hogy elveszítette a szüleit, és kirekesztő gondolkodású nevelőszülőkhöz kerül, akik bár a saját családtagjai, mégsem bánnak Harryvel megfelelően. Pottert az teszi a családban hátrányossá, hogy több képességgel 
rendelkezik, mint a család más tagjai, mégsem élvez azonos jogokat a család többi tagjával.

A könyvek mindannyiuk elfogadására motiválják az olvasót: a szereplök nem pusztán elfogadják egymást, de mind készek segíteni egymáson.

J. K. Rowling müvei alapján megtanulhatjuk azt, hogy az iskola, amely a négy alaperényt átadja diákjainak, rendkívül fontos, de még fontosabb az, hogy az intézményrendszerek, amelyek a fennálló társadalomszervezési ajánlatot hivatottak kialakítani a gyakorlatban, stabilak legyenek. A tolerancia-kultúra a II. világháború után kivételes fontossággal bírt, azonban az egymás iránti tisztelet kultúrája ott van, ahol az ókori görög filozófia által is megfogalmazott erényeket megtanítja az oktatási rendszer a következő generációknak. A tanulmány szerzői lényegében azt állítják, hogy a Harry Potter regények ilyenformán olyan hatással vannak az olvasókra, mintha ők maguk is a Boszorkány- és Varázslóképző Szakiskolába jártak volna. A különbség azonban az, hogy a kutatásban résztvevők toleranciaszintjének emelkedése nem varázslat volt, hanem tudomány.

A társadalomszervezés egyik legfontosabb intézménye az iskola. Mivel a vezetés, az erkölcs és a tudomány kéz a kézben járása elengedhetetlen egy sikeres társadalom kiépítéséhez, olyan iskolára van szükség, ahol mindhárom egyszerre van jelen. A tolerancia-eszme a globális kihívások és társadalmi válságok miatt való megkérdőjeleződése veszélyt jelent a társadalom egészére, emiatt fontos, hogy a társadalomszervezést az alaperények mentén kezdjék el, így kiszürhetők a toleranciaeszme lényegéből eredő saját korlátok, és kirekeszthetők a társadalom rombolására tett kísérletek: kiszürhető, hogy az értékrend nélküli erő kerekedjen felül egy közösség életében.

Az iskola szerepe az államigazgatás keretein belül, a társadalomszervezési ajánlat értékrendjében és a mindennapi életben használatos tudás átadásában fogható meg. Ezek közül az értékrend hosszú távú stabilitása a mindenkor fennálló állami intézményrendszert is ellenőrzi, ugyanakkor az intézményrendszer feladata az értékrend feletti örködés is. Az értékrend így eszköz és cél is egyúttal.

A dolgozat írása közben olyan felismerésre jutottam, hogy a piaci intézményrendszer kiépítése társadalomszervezői szándék, ugyanakkor döntően befolyásolja a piaci szereplők egymáshoz való viszonyát is.

A jogállami keretrendszer a polgárok önszerveződő érdekvédelmi szervezeteinek és intézményrendszereinek is teret enged. A munkavállalói érdekképviselet és a 
fogyasztóvédelem például nem a piacgazdaság ellenségei, hanem a „legjobb barátai” és „testőrei”. Az olyan nemzetgazdaságokban, ahol a társadalomszervező a polgárokat szabad embereknek tekinti, akik szabad elhatározásukból érdekképviseleti szerveket hozhatnak létre, úgy ők maguk is hozzájárulhatnak a tisztességtelen piaci magatartás kiszüréséhez.

Ehhez olyan jogrendszer szükséges, amiben tudjuk, hogy a törvények stabilak, nem szolgálnak különböző érdekcsoportokat.

A felelős kormányzás ma már nem a minél kisebb államot jelenti. A minimális állam melletti érvelés nem állja meg a helyét, amint az esélyegyenlőtlenségek korrigálásának kötelezettségére koncentrálunk. Hamis kép, hogy az esélyegyenlőségi küzdelem és a teljesítményelv szembemennek egymással. Előbbi esetén csak arról van szó, hogy a nyomorba született társadalmi csoport tagjai is megmutathassák, mit tudnak, és hasznos tagjai lehessenek úgy a nemzetgazdaságnak, mint a társadalomnak.

Mit jelent ez a társadalomra nézve? A dolgozat állítása továbbá, hogy a piacgazdaság nem maradhat meg a maga XX. századi állapotában. A fenntartható fejlődés kérdésköre nem pusztán természeti és környezeti, de társadalmi, pénzügyi és költségvetési értelemben is alapköve lesz a jelenkor és a jövő stabilitásának. Ebben benne foglaltatnak azok a szabályozások, amelyek a piaci szereplöket a környezettudatosság felé terelik. Pozitív ösztönzők beépítésével, a társadalmi felelősségvállalás „divatossá” tételével a legnagyobb piaci szereplők is átirányíthatók a hulladékminimalizálásra, müanyagmentességre és újrahasznosításra.

$\mathrm{Az}$ államszervezés és társadalomszervezés ilyen irányú másik építőeleme az intézmények és a törvények müködőképessége abból a szempontból, hogy ösztönzike a polgárokat a helyes, erkölcsös viselkedésre. Samuel Bowles 2018-ban megjelent, Etikus gazdaság címü könyve arra hívja fel a figyelmet, hogy az elmúlt évtizedben uralkodó nézetként szinte minden más döntési mechanizmust elfedő homo oeconomicus képét át kell alakítanunk. Az etikai alapon is méltányos ösztönzőrendszer létrehozása mellett érvel, és számos olyan esetet is elemez, amelyekben ezt bizonyos társadalmak vagy intézmények megpróbálták, de nem jártak sikerrel. Azért fontos ez, mert ez a tudomány jóval összetettebb annál, mint amilyennek elsőre gondolnánk. A jó állampolgárokat ugyanis nem helyettesítik a jó ösztönzők, sőt, létezik olyan ösztönző- és büntetőmechanizmus, amely képes még a jó állampolgárok viselkedését is elterelni a morálisan helyes útról. 
Samuel Bowles olyan példákat említ, amelyeken keresztül világossá válik, hogy az emberek nem pusztán a pozitív ösztönzők miatt akarnak jót cselekedni (sőt, egy kísérlet azt bizonyította, hogy a korábban készségesen segítő gyerekek többnyire felhagytak a szüleiknek való segítségnyújtással, amint jutalmat helyeztek számukra kilátásba a segítségért), és az államilag szabályozott büntetőmechanizmusok sem garantálják a polgárok kihágásainak felszámolását. (A szülők óvodából való késéseinek pénzbüntetéssel való sújtását például - egyébként részben meglepő módon - úgy fogták fel az érintettek, hogy a szabály életbelépését követően már „megvásárolják” az óvónénik túlóráját, így még kevésbé igyekeztek pontosan érkezni, és a késések összes időtartama jelentősen megnövekedett.)

Ha a környezetvédelmet tekintjük, akkor jelen van benne mindkét, fentiekben bemutatott módszer. A háztartások felelősségvállalása edukációval és ösztönzőkkel segíthető, amennyiben az állam által felépített intézményrendszerek - mint a hulladékelszállítás és annak hasznosítása - rendben vannak. Fontos megjegyezni, hogy a liberalizmus - úgy elméletben, mint gyakorlatban - nem csak a szabadságról, de legalább annyira a kooperációról is szól. A szocializációs edukációnak éppen ezért kell szólnia az együttmüködőkészség fejlesztéséről, és ezen keresztül a társadalmi kohézió előremozdításáról. Vezzali és szerzőtársai a fent bemutatott tanulmányban erre találtak egy lehetséges módot, de számos olyan iskolai módszertant és gyakorlatot ismerünk, amely ugyanezeket a célokat szolgálja.

Ebben bizonyosan változtatni kell a liberálisoknak is, ezek olyan állami beavatkozások, amikért az egyénnel együttmüködve a helyi vagy az országos vezetés vállal felelősséget a globális célokért.

Ugyanígy igaz ez a társadalmi értelemben való fenntarthatóságra, a különböző társadalmi csoportok esélyegyenlőségére is: ha a leszakadó rétegek örökre elvesznek a kiszolgáltatottságban, az nemzetgazdasági veszteségeket okoz: annak is rossz, aki adott pillanatban a szerencsésebb társadalmi rétegek egyikének tagja.

Hosszú távú GDP-növekedési rátamódosító hatása van annak, hogy a társadalom bizonyos tagjait megfosztják az esélyegyenlőségtől. Így erőforrásokat veszít a gazdaság. Ez már csak pragmatikus alapon sem megengedhető, mert gyakorlatilag a többi társadalomhoz mérten relatív elszegényedéshez vezet. Ennél azonban többről van szó. A klasszikus liberális elvektől való elszakadás az, ha egy társadalom széles rétegek kezét engedi el az egyenlő méltóság és az egyenlő bánásmód kérdésének tekintetében. 
A jogok és kötelességek tudata éppolyan fontos kérdés, mint a felelősségvállalás és a szabadság kettőse. Az iskolákban folyó oktatás ebben nagy segítségünkre lehet. Emiatt fontos, hogy a nagy intézményrendszerek és a közjavak elégséges szintjének a követelése mellett egy jogtudatossággal rendelkező embereket nevelő iskolarendszerért is síkra szálljunk. Nem pusztán a jogtudatosság, de a gazdaságstratégiai tervezés is az iskolarendszeren múlik. Ez a kettő összetartozik. Ha nincs tudásalapú társadalom, akkor nincs gondolkodó ember, maradnak az alacsony hozzáadott értékü munkahelyek, és ezzel a gazdaságstratégiai tervező beárazza a saját munkapiacát.

A IV. ipari forradalom zajlik, sokaknak robotok, gépek veszik majd át a munkáját, a legtöbbek szakmája nem létezik majd néhány évtized múlva. Emiatt nagyon fontos az élethosszig tartó tanulás kérdésköre, és az is, hogy ahogyan a gépek veszik át a szerepet a munkapiac egyre több szegmensében, az embereknek ettől még jövedelemre van szükségük, és arra is, hogy az így felszabaduló idejüket értékesen töltsék.

A jövedelem kérdésében liberális álláspont lehet például, hogy a munkáltatók a jelenlegi kétkezi munkavállalókra is kiterjesszék a részvénytársaságot. Döntően aluliskolázott rétegek érintettek, az ő jövedelemforrásuk nem szünhet meg. Amennyiben a kétkezi munkák egy részét gépek veszik át, egyrészt a gépek müködtetésére kell átképezni a jelenlegi munkavállalókat, másrészt, ha valaki munkája tényleg egyszerüen helyettesíthető egy géppel, akkor neki tulajdoni hányadot kell birtokolnia a korábbi munkáltatójánál.

Az emberiség jövője szempontjából létkérdés egymás elfogadása és a másik ember tisztelete. E felvetés abból ered, hogy sokaknak a IV. ipari forradalom miatt felszabadul majd a munkaidő egy része vagy egésze. Ez már azoknak a sci-fiknek a kérdésköre is, amelyek egy olyan világot írnak le, amelyben a munkavégzés hiánya miatt az embereknek máshogyan kell társadalmat szervezniük. Nem szakadhatnak meg a társas kapcsolatok, közösségek nélkül a jelenlegi kihívások közepette semmire sem megyünk. A szóbeszéd szerint Charles De Gaulle kultuszminisztere, André Malraux azt mondta: „a XXI. század vagy spirituális lesz, vagy egyáltalán nem lesz”. Úgy vélem, igaza volt, és erre a liberális eszmerendszernek is kell, hogy legyen válasza. Wilhelm Röpke gondolatai között megtalálhatók ezek a válaszok, a természet és Isten közelségével.

Az ordoliberalizmus liberalizmusfelfogása abban különbözik a neoliberalizmusétól, hogy bár az egyén szabadsága fontos, a közösségeket is fontosnak tartja. Ezt Dardot 
és Laval a Globálrezon címü könyvében új racionalitásnak nevezi, mely szóhasználatot én is átvettem a dolgozatban. Ebben a felfogásban, a következő társadalomfejlődési lépcsőfokon, az egyéni felelősségvállalást meghaladva, a közösségi felelősségvállalás jelenik meg az emberekben. Ezen alapul a rászorultsági elven müködő segélyezés, ezen alapul az iskolák integrációs programjainak szorgalmazása, valamint az esélyegyenlőség előmozdítására felállított intézményrendszer.

A fentiek igazak a piaci folyamatokra. A társadalom tagjait célszerü olyan irányba edukálni, hogy felismerjék: nem a piaci folyamatok károsak. Amitől az emberek félnek, az nem a piac, hanem a tisztességtelen piaci magatartás. Fontos, hogy az iskolába ne csak a tolerancia és az egymás iránti tisztelet, valamint a jogtudatosság kultúrája kerüljön be, hanem az a gondolat is, hogy a verseny és a piac jó. A szilárd hit abban, hogy cserélünk egymással tudást, terméket, szolgáltatást, mindenki számára jobb életet jelent, újfajta módon teremt versenyképes vagy piackompatibilis társadalmat.

A liberalizmus elméleti képviselői készek voltak felvázolni egy olyan gazdaságstratégiai, társadalomszervezési és intézményrendszeri ajánlatot, amely kész a klasszikus liberális elvek gyakorlati megvalósulása mellett választ találni a jelenkor kihívásaira.

A piac szabályozására talán a legjobb leíróeszköz a folyószabályozás példája. A folyószabályozás olyan emberi beavatkozás, amely a társadalom és a természet együttélését teszi lehetővé úgy, hogy közben nem rombolja a természetet. A neoliberalizmus ezt nem tette meg, az ordoliberalizmus azonban igen. Az elméleti keret adott arra, hogy a XXI. századi kihívásokra a liberális eszmerendszeren belül vázoljunk fel gazdaságstratégiai és társadalomszervezési ajánlatot.

Az, hogy a liberalizmus gyakorlati képviselői képesek lesznek-e az elmélet gyakorlatba való átültetésére, kívül esik a dolgozat vizsgálódásán.

\section{Zárszó helyett}

Nehéz meghatározni, ez a dolgozat hol kezdődik és hol ér véget, csakúgy, ahogyan a társadalmi kihívások és a civilizált ember története. A liberális eszmerendszer megújulására tett kísérletek a felvilágosodás kora óta mindig új válaszokat adtak a társadalomnak és a társadalomszervezőknek, ha pedig később ezek a válaszok nem bizonyultak maradéktalanul jónak vagy egy nem várt új hibát generáltak, volt javítási 
lehetőség. A dolgozatot a javítási lehetőség kísérletének szándéka ihlette, ha tanulmányról lenne szó, és kategóriát keresnének neki a bírálók vagy a folyóirat szerkesztőbizottságának tagjai, a legnagyobb valószínűséggel azt a rubrikát ikszelnék be: ,vitaanyag”.

A megírásával szeretnék hozzájárulni ahhoz a vitához, hogy vajon sokak állítása, miszerint a liberális eszmerendszer elbukott, legutóbbi eszmetörténeti hibáiból már nem tud felállni, és mivel nem szolgálja a társadalomfejlődést, így egészét tekintve lezártnak tekintendő, igaz lehet-e.

A dolgozat elemzi a globalizációs folyamatokat is. A globalizáció úgy is összefoglalható, hogy a globális kihívások és az ezeknek megfelelni akaró globális intézményrendszer vezeti a tudományt, határozza meg a megoldandó tudományos problémákat. Ezt azért tartom fontosnak, mert a járvány kezelésében azok a társadalmak voltak a legsikeresebbek, amelyek nem vették ki a polgárok kezéből a döntést a szakértelemre hivatkozva, ugyanakkor elegendő szakszerü információval látták el öket annak érdekében, hogy hogyan tudnak vigyázni az egészségükre, és mi a teendőjük, ha megfertőződtek.

A cselekvő állam feladata ebben az esetben abban állt, hogy a polgárok járványügyi szempontból helyes viselkedéséhez igazította az intézményrendszert, valamint a cselekvési tervét, és segített az embereknek abban, hogy ők maguk megfelelően védekezzenek és cselekedjenek. A liberalizmus lényegében ezt jelenti: a szabadságon alapuló rend létrehozását.

A liberalizmus és a szakértelem összekapcsolódása fontos a XXI. században, most már az életünk minden területén. A járvány első hulláma közepette hangzott el a gondolat, miszerint „az emberek nem azért mosnak kezet, mert azt a szappanrendörség ellenörzi, hanem azért, mert megértették, hogy miért fontos a kézmosás, és mit kockáztatnak azzal, ha nem teszik”.

A liberális eszmerendszer történetének és eszmetörténeti szakaszainak talán legfontosabb tanulsága az, hogy a társadalom legsikeresebb éveit azokban az idöszakokban találjuk, amikor a szabadságot és a demokráciát a helyes döntések megtalálása érdekében szervezték. E szervezési mód megtalálása ma már nem nemzeti, de még csak nem is európai, hanem globális kérdés.

Különös, hogy ennek a dolgozatnak az utolsó oldalai azután születnek, hogy a populizmus harmadik hullámának térnyerése az Egyesült Államokban elkezdett visszaszorulni. Kérdés, hogy ez miben változtathatja meg a korszellemet a következő 
években. Az új korszak kezdete feltehetően ahhoz a gondolathoz való visszatérést jelenti, hogy globális szinten kell megtalálni a helyes technológiát, és mind többek boldogulásáért érdemes tenni - még akkor is, ha ez adott esetben egy nemzetgazdaság vagy egy régió időleges pozícióvesztésével jár együtt.

A szemléletváltást azért lesz érdemes figyelni, mert ha az USA politikai és társadalmi többsége megérkezik a gondolathoz, miszerint nem a multinacionális vállalatok tartják össze a világot, hanem a technológiai platformok - például az egészségügyi, élelmiszerbiztonsági és környezetvédelmi sztenderdek -, egy másik minőségü globalizációs folyamatban találjuk magunkat. A sztenderdekbe való bekapcsolódás nem arról szól, hogy mely nemzetgazdaság ereje képes kikényszeríteni a többiekből a saját akaratának megfelelő szabályozást, hanem arról, hogy a - lehetőség szerint globális szintü - szövetségesek képesek-e értéket közvetíteni a polgárok felé, és képesek-e a polgárok mindennapjaiban érvényesíteni ezeket az értékeket.

Az Európai Unió globális térvesztése, valamint az e kihívásra adható lehetséges válaszok azért kaptak helyet a dolgozatban, mert az EU jelenleg versenyt fut az idővel. Amennyiben a fejlődő világban egyelőre fennálló diktatórikus rendszerek és emberi méltóságot nem tisztelő politikai kultúrák állnak fenn, párosulva páratlan gazdasági növekedéssel, amelyek néhány évtizeden belül a világgazdaság élvonalába sorolhatják öket, akkor megtörténhet, hogy a globális sztenderdek az ő akaratuknak megfelelően alakulnak. Ez pedig egyet jelent azzal, hogy a szabad világ jogrendszerével ellenkező módon kellene szervezni a nemzetközi gazdaságot. Ez a jelenleg ismert legmagasabb életminőséget biztosítani képes országok társadalmai szempontjából egészen biztosan visszalépés, de a fejlődők lehetséges jövője szempontjából is káros és sötét képet vázol fel mindannyiunk számára.

A globális folyamatok történnek, megállíthatatlanok, de mederbe terelhetők és irányíthatók. Ezekbe a folyamatokba illeszkedik az Európai Unió, ennek megfelelően tudjuk értelmezni és szervezni a világgazdaságot és a nemzetgazdasági folyamatokat. Ha ma valaki azt mondja, hogy a gondolat, miszerint ,a politikusok feladata a hazájuk globális trendekhez való igazodásának segítése” pusztán egy idealista eszménykép, akkor lényegében arról mond le, hogy a XXI. században találhatunk megfelelő választ a kihívásainkra, legyenek azok természeti, társadalmi, egészségügyi vagy gazdasági nehézségek.

A szubszidiaritás elvéből az következik, hogy az adópolitikát a demokratikus értékeknek megfelelően kell szervezni. A nagyvállalatok kisvárosoktól való 
távolmaradásával például nem biztos, hogy rosszul járnak a városok polgárai, mert így fennmaradhatnak a helyi kisvállalatok, és müködhet a helyi gazdaságban a demokratikus értékrend, az évtizedes történelemre visszatekintő helyi ipartestületek. Ezek jó példát adtak arra, hogy a helyben keletkezett, nemzedékről nemzedékre továbbadott tudás értékként megörizhető.

A részvételprobléma liberális kérdés. Ha valaki lemond a részvételéröl, szolgává válik - Friedrich A. Hayek emellett érvelt az Út a szolgasághoz címü müvében. A szabadság és a rend közti összhang megtalálása a liberális eszmerendszer elméleti és gyakorlati megvalósítóinak legnagyobb kérdése. Az ordoliberalizmus korszaka egy olyan időszak volt, amelyben sikerült megtalálni ezt a harmóniát, és a társadalom tagjainak nagy többsége úgy vált - az egész nemzetgazdaságra jótékony hatást gyakorolva ezzel - szabálykövetővé, hogy közben nem érezte azt: a központi kormányzat vagy az állam gúzsba köti, mert hogy nem is így történt. Mind a piacot, mind a jogállamot, mind a demokráciát a polgárok szabadságának érvényesülése érdekében és a tisztességtelen magatartás visszaszorításáért szervezték. A polgárokban így automatikusan alakulhatott ki a tudat, hogy a szabályok betartásáért vállalt felelősségükön keresztül megvalósul a szabadságuk.

Éppen emiatt mondhatjuk ki, hogy az anarchizmussal való vitát ma nem kell szélsőségig vinni. Korábban polgárháborúk dúltak az anarchizmussal, mára alig maradt, aki úgy hiszi, jogállam, erőszakmonopólium és demokratikus intézményrendszer nélkül lehet társadalmat szervezni. Kérdés, hogy ezen intézmények felépítéséből szociáldemokraták, konzervatívok és liberálisok hogyan veszik ki a részüket a XXI. században. Ha a liberálisok „pusztán” a szabadság és a rend összhangjáért küzdenek meg ebben a sok tekintetben kaotikussá vált világban, a saját feladatukat már elvégezték.

Amennyiben a három eszmerendszer képviselői képesek és hajlandók tanulni egymástól, annak az elkövetkezendő évtizedekben - meglátásom szerint - rendkívül pozitív hatásai lesznek a társadalomszervezés és a gazdaságstratégiai tervezés, végső soron a polgárok mindennapjainak minősége szempontjából.

A megfelelő oktatási rendszer szervezése, a polgárok jósága éppúgy hozzájárul a lehető legjobb társadalomszervezési ajánlat megtalálásához, mint a jó ösztönzők és a működő jogállam. Ha pedig az oktatási rendszer képes átadni az évezredek óta ismert erényeket a felnövekvő nemzedékeknek, talán hihetünk abban, hogy az alkotmányt (Samuel Bowles szavaival élve) nem ,gazfickóknak” - és reményeink szerint - nem 
is ,gazfickók” írják. A fentiekben részletezett rendszer a dolgozat állítása szerint elegendő lehet az új évezred kihívásaira adott megfelelő válaszok megtalálásához. Mindezzel arra szeretnék rámutatni, hogy a társadalom azokban a pillanatokban volt a legsikeresebb az emberiség rövid története során, amelyekben a gazdasági- és társadalmi folyamatok szervezését etikai megfontolás is vezette.

„Ha mi árnyak nem tetszettünk,

Gondoljátok, s mentve tettünk:

Hogy az álom meglepett,

$S$ tükrözé e képeket.

E csekély, meddö mesét,

Mely csak álom, semmiség,

Nézze most el úri kegy,

Másszor aztán jobban megy.

$S$ amint emberséges Puck

A nevem: ha megkapjuk,

Hogy most kímél a fulánk,

Jóvátesszük e hibánk,

Máskint a nevem ne Puck

Legyen inkább egy hazug.

Most uraim, jó'tszakát. -

Fel, tapsra hát, ki jó barát,

S Robin megjavitja magát."

(William Shakespeare: Szentivánéji álom, részlet, ford. Arany János) 


\section{Felhasznált irodalom}

Ágh, A. (2019): A neoliberalizmus tündöklése és hanyatlása: válóper az Európai Unió és az Egyesült Államok között, in Antal: Neoliberális Hegemónia Magyarországon elemzés és kritika, Noran Libro Kiadó, Budapest, ISBN: 978-615-5900-45-7

Alliance of Liberals and Democrats for Europe Party (2014): ALDE Party Reclaiming Liberalism. Handout at 2014 Lisbon Congress.

Alliance of Liberals and Democrats for Europe: $A L D E$ Party Congress opening speeches: https://www.aldeparty.ez/news/watch-again-alde-party-congress-openingceremony-speeches

Lekérdezve: 2016. 04.08.

Ambrus, R. A. (2017): Európai uniós adópolitika és nemzeti adórendszer, „Geopolitikai stratégiák Közép-Európában” Nemzetközi tudományos konferencia Sopron, 2017. november 9. ISBN 978-963-359-091-1

Andor, L. (2018): Resources for a Prosperous Europe-Redesigning the EU Budget in a Progressive Way. WISO Diskurs, Friedrich-Ebert-Stiftung Economic and Social Policy ISBN: 978-3-96250-201-0

Antal, A. (2019): Az autoriter neoliberalizmus, in Antal: Neoliberális Hegemónia Magyarországon - elemzés és kritika, Noran Libro Kiadó, Budapest, ISBN: 978-615$5900-45-7$

Balla, A. (1926): A liberalizmus történelme in: Gazdasági és politikai tanításai, Légrády Nyomda és Könyvkiadó R.-T. kiadása, Budapest

Bajona, C. - Kehoe, T. J. (2006): Trade, Growth, and Convergence in a Dynamic Heckscher-Ohlin Model, Working Paper 12567

Barta, A. (2009): Tocqueville az amerikai közigazgatásról. Miskolci Jogi Szemle, Egyetemi Kiadó, Miskolc, 4(1) ISSN 1788-0386

Barta et al. (2008): Koraújkortörténet, Budapest, szerkesztette: Poór János, online elérhető: http://real.mtak.hu/2011/1/49626_ZJ1.pdf Lekérdezve: 2019. február

Békés, G. (1998): Optimális valutaövezetek, gazdasági integráltság és hasonlatosság: az Európai Unió példája. Közgazdasági Szemle, 45(3) 709-737.

Benczes, I. (2016): A washingtoni konszenzus és a nemzetközi pénzügyi szervezetek, Köz-Gazdaság, 2013 (3), pp. 107-123.)

Beveridge, J. (1954): Beveridge and His Plan. London: Hodder and Stoughton

Blahó A. - Benczes I. (2002): „A nemzetközi gazdasági diplomácia fö kérdései a XX. század végén” in: Blahó A. (szerk.): Világgazdaságtan 2. Budapest: Aula Kiadó 
Boas, Taylor C. - Gans-Morse, Jordan (2009): Neoliberalism: From New Liberal Philosophy to Anti-Liberal Slogan (The article was published with open access at Spingerlink.com, in 2009)

Bockmann, J. (2011): Markets in the Name of Socialism - The Left-Wing Origins of Neoliberalism, Ebook ISBN: 9780804778961

Borrman, A. - Koppmann, G. (1994): Regionalisation and regionalism in world trade. Intereconomics. 29(4), 163-170. ISSN 0020-5346 http://dx.doi.org/10.1007/BF02926434

Bowles, S. (2018): Az etikus gazdaság - Miért nem helyettesithetik a jó ösztönzők a jó állampolgárokat? Pallas Athéné Könyvkiadó Kft. ISBN: 9786155884153

Bősz, A. (2020): A fenntarthatóság és az új generáció szemlélete, Köz-Gazdaság, 2020/1, p. 72-84.

Bősz, A. (2016): Az Európai Unió és a liberális eszmerendszer. Köz-Gazdaság 10(2) 171-191. http://old.uni-

corvinus.hu/fileadmin/user_upload/hu/kozponti_szervezeti_egysegek/karrier_iroda/fi les/XI-2szam/171-192 Bosz.pdf

Bösz, A. (2017): Harmonising liberalism and realism in the theory of international relations. Ekonomické Rozdhl'ady/Economic rewiew 46(3) 199-219. https://euba.sk/www_write/files/SK/ekonomickerozhlady/er3 2017 bosz fulltext.pdf

Bősz, A. (2017): Szabadpiaci-elméletek, szabadkereskedelmi megállapodások és az V. európai korridor szerepei, Létünk 47(3) 139-158. http://epa.oszk.hu/00900/00997/00044/pdf/EPA00997_letunk_2017_3_139-158.pdf

Bősz, A. (2017): Mi következik a neoliberalizmus után? Tavaszi szél konferencia tanulmánykötet, szerk. Keresztes G. p. 178-188. o. Kiadó: DOSZ, ISBN: 978-6155586-18-7

Bush, U. - Land, R. (2009): Deutschland zwischen 1950 und 2009 -

Wirtschaftsentwicklung und Teilhabe (Der Teilhabekapitalismus und sein Ende, Entwurf Okt. 2009) http://www.rlatexte.de/texte $/ 2 \% 20 \mathrm{a} \% 20 \mathrm{SOEB} / \mathrm{SOEB} \% 20 \mathrm{Makro} \% 20 \mathrm{Okt} \% 202009-12$ 01\%20busch\%20land.pdf

Caldwell, B. (2020): The Road to Serfdom after 75 Years, Journal of Economic Literature 58(3), 720-748 https://doi.org/10.1257/jel.20191542

Chryssogelos, A. S. (2013): The Evolution of the 'populist Potential' in European Politics: From New Right Radicalism to Anti-system Populism, European View, vol 12 (1), p. 75-83. 
Cockett, R. (1995): Thinking the Unthinkable: Think-Tanks and the Economic Counter-Revolution, 1931-1983. London: HarperCollins.

Czeglédi, P. (2012): Szabadságjogok és gazdasági szabadság - a gazdasági növekedés két különbözö tényezője? E-Conom, 2012. 1(2) 2-13. ISSN 2063-644X

Dardot, P. - Laval, C (2013): A globálrezon, a neoliberalizmus múltja és jelene, EgyKettő kiadó, Budapest

Delors, J. (2013): Az új európai összhang. L'Harmattan Kiadó, Budapest, ISBN: 9789632366760

Deneen, P. J. (2018): A liberalizmus kudarca, Institute for Advenced Studies in Culture, University of Virginia, ISBN: 978-963-433-558-0

Duménil, G. - Lévy D. (2013): The Crisis of Neoliberalism. Harvard University Press, Cambridge

Durkheim, E. (1992): Professional Ethics and Civic Morals. Routledge New York

Egedy G. (2011): Bevezetés a nemzetközi kapcsolatok elméletébe. http://www.grotius.hu/doc/pub/KWIOYM/2012 50 egedy gergely bevezetes.pdf Lekérdez-ve: 2020. 04. 21.

Egyed, P. (2003): A liberalizmus mint politikai filozófia, Pártok Európában https://epa.oszk.hu/00400/00458/00070/2003honap10cikk427.htm

Eichengreen, B. - Ritschl, A. (2008): Understanding West German Economic Growth in the 1950s, Working Papers Economic History, No. 113/08 http://www.lse.ac.uk/Economic-

History/Assets/Documents/WorkingPapers/Economic-History/2008/WP113.pdf

ENSZ: 1956. évi I. törvény az Egyesült Nemzetek Alapokmányának törvénybe iktatásáról

https://net.jogtar.hu/jogszabaly?docid=95600001.tv

Erasmus-program: Kiutazó magyar hallgatók száma - grafikon http://piackutatas.blogspot.hu/2013/12/erasmus-program-kiutazo-magyar.html

Erhard, L. (1990): Jólétet mindenkinek. Konrad Adenauer Alapítvány Budapesti Képviselete, Budapest ISBN: 9630438283 (1957)

Eucken, Walter (1948): Das ordnungspolitische Problem, in: ORDO 1, S. p. 56-90.

European Commission: An Introduction to the European Cohesion Policy 20142020 .

https://ec.europa.eu/regional policy/sources/docgener/informat/basic/basic 2014 en. pdf Lekérdezve: 2020. 04. 21. 
European Comission: Cohesion Fund of the European Union. http://ec.europa.eu/regional_policy/en/funding/cohesion-fund

European Comission: European Regional Development Fund. https://ec.europa.eu/regional_policy/en/funding/erdf/_Lekérdezve: 2020. 04. 21.

European Commission: Transatlantic Trade and Investment Partnership - The Economic Analyses

Explained. https://www.europarl.europa.eu/RegData/etudes/etudes/join/2014/528798/IPOLJOIN_ET\%282014\%29528798_EN.pdf_Lekérdezve: 2020. 04. 21.

European Commission (2015): Investing in regions: The reformed EU Cohesion Policy 2014-2020. http://ec.europa.eu/regional_policy/sources/docoffic/official/regulation/pdf/2014/pres entation_final_en.ppt. Lekérdezve: 2020.04. 21.

European Union (1992): Maastricht Treaty. https:/europa.eu/europeanunion/sites/europaeu/files/docs/body/treaty on european union en.pdf Lekérdezve: 2020. 04. 21.

European Union (2014): Making Europe's regions and cities more competitive, fostering growth and creating jobs. http://ec.europa.eu/regional_policy/en/information/publications/brochures/2014/theeu-explained-regional-policy-making-europes-regions-and-cities-more-competitivefostering-growth-and-creating-jobs Lekérdezve: 2020. 04. 21.

FDP (2017): Bundestagswahlprogram, Freie Demokraten (FDP), FDPBundesgeschäftsstelle, Reinhardtstraße 14, $10117 \quad$ Berlin https://www.fdp.de/sites/default/files/uploads/2017/08/07/20170807-wahlprogrammwp-2017-v16.pdf Lekérdezve: 2018. 04. 05.

Éber, M. Á. (2019): Neoliberálisok az államszocialista Magyarországon, in Antal: Neoliberális Hegemónia Magyarországon - elemzés és kritika, Noran Libro Kiadó, Budapest, ISBN: 978-615-5900-45-7

Fekete, L. (1997): Adam Smith Nemzetek gazdagsága és a felvilágosodás filozófiája. Department of Microeconomics, Budapest University of Economic Sciences, REPLIKA (31-32). p. 99-120. ISSN 0865-8188

Ferejohn, J. A. - Rosenbluth, F. M. (2006): Toward a Republican Liberalism. http://dx.doi.org/10.2139/ssrn.1154097

Formaini, R. L. (2004): David Ricardo - Theory of Free International Trade, Economic Insigths, Federal Resefve Bank of Dallas, vol. 9. no. 2. https://www.dallasfed.org/ /media/documents/research/ei/ei0402.pdf

Fukuyama, F. (2014): A történelem vége és az utolsó ember. Európa Könyvkiadó, Budapest, ISBN: 9630795739 
Gaulier, G. - Jean, S. - Ünal-Kesenci, D. (2004): Regionalism and the Regionalisation of International Trade, CEPII, Working Paper No 2004-16

Gálik, Z. (2006): A közös európai külpolitika elmélete - A neoföderalizmustól a külpolitikai döntéselméletig. Budapesti Corvinus Egytem, Nemzetközi Kapcsolatok Doktori Iskola http://phd.lib.uni-corvinus.hu/15/1/galik_zoltan.pdf

Gedeon, P. (2007): Piaci rend és társadalmi normák Hayek elmélete a társadalmi evolúcióról, Közgazdasági Szemle, LIV. évf., 2007. január p. 1-28.

Gervai, P. - Trautmann, L. (2013): A neoliberális "kapitalizmus" fogalom megszünése (The disappearance of the term “neoliberal capitalism”). Köz-gazdaság, 8 (1). p. 35-52.

Greenleaf, W. H. (1983): The British Political Tradition, Volume Two, University Press, Cambridge

Grieco, J. (1988): Anarchy and the Limits of Cooperation: A Realist Critique of the Newest Liberal Instititionalism. International Organization, 42(3), 485-507.

Grundgesetz für die Bundesrepublik Deutschland vom 23. Mai 1949. http://www.documentarchiv.de/brd/1949/grundgesetz.html Lekérdezve: 2020.04.21.

Gaulier, G. - Jean, S. - Ünal, D. (2004): Regionalism and the Regionalisation of International Trade. Working Paper, CEPII research center

Gupta, S. D. (2009): Comparative Advantage and Competitive Advantage: An Economics Perspective and a Synthesis. St. Thomas University Fredericton, N. B., Canada

Gyurácz, F. (2017): „,Populizmus”, 2016-17. Hitel - Kérdez az idő, Hitel Irodalmi és Társadalmi Folyóirat 30(12) 3-26.

Hall, D., et al. (1975): The Frustration of Science. London: Arno Press. (1935).

Halmosi, P. (2004): Az adórendszer kihívásai és lehetséges válaszai az Európai Unióban, szerk. Botos K. Pénzügyek a globalizációban, SZTE GTK, JATEPress, Szeged, p. 19-31.

Harvey, D. (2007): A Brief History of Neoliberalism, Oxford University Press, Oxford, ISBN: 0199283273

Hayek, F. A. (1996): Individualism and Economic Order. University of Chicago Press, Chicago

Hayek, F. A. (2011): The Constitution of Liberty: The Definitive Edition. Vol. 17, Collected Works of F. A. Hayek, edited by Ronald Hamowy. Chicago: University of Chicago Press. (1960) 
Hayek, F. A. (1967): Studies in Philosophy, Politics and Economics. London: Routledge and Kegan Paul

Henderson, D. R. (2018): The German Economic Miracle, The Concise Encyclopedia of Economics, Library of Economics and Liberty

Heywood, A. (2003): Political Ideologies: An Introduction. $3^{\text {rd }}$ edition. New Yord: Palgrave Macmillan

Hobbes, T. (1970): Leviatán. Magyar Helikon, 1970.

Hodder, N. (2019): Wirtschaftswunder: A Study into the Causes and Catalysts of the German Economic Miracle, Liberty University

Huntington, S. P. (1998): Civilizációk összecsapása és a világrend átalakulása. Európa Kiadó Budapest, ISBN: 9789630795722

Hume, D. (1748, 2014): Tanulmány az emberi értelemről, a fordítás online elérhető: https://www.scribd.com/document/237239070/Hume-Tanulmany-Az-Emberi-

Ertelemr\%C5\%911 Lekérdezve: 2019. november

Jakab A. - Urbán L. (2017): Hegymenet - Társadalmi és politikai kihívások Magyarországon, Osiris Kiadó, Budapest, ISBN: 9789632762869

Johnson, H. G. (1954): Optimum Tarifs and Retaliation. Review of Economic Studies. 21(2), 142-153.

Kant, I. (2015): Az örök béke. Digi-Book Magyarország kiadó ISBN 978-963-398191-7 EPUB https://play.google.com/books/reader?id=1KVUCwAAQBAJ\&hl=hu\&pg=GBS.PT2

Kant, I. (1991): Az erkölcsök metafizikájának alapvetése - A gyakorlati ész kritikája Az erkölcsök metafizikája. Gondolat kiadó, Budapest ISBN: 963-282-477-6

Kardos, G. (2007): Nemzetközi jog a hidegháború után. Rada Péter: Új világrend? Nemzetközi kapcsolatok a hidegháború után. Grotius könyvtár I. 37-52 ISBN 978963-06-2637-8

Kapelner, Zs. (2019): A neoliberalizmus dialektikája: a spontaneitástól az uralomig, in Antal: Neoliberális Hegemónia Magyarországon - elemzés és kritika, Noran Libro Kiadó, Budapest, ISBN: 978-615-5900-45-7

Kehoe, T. J. - Bajona C. (2010): Trade, Growth, and Convergence in a Dynamic Heckscher-Ohlin Model. Review of Economic Dynamics 13(3) 487-513

Keohane, R. O. - NYE, J. S. JR. (2012): Power and Interdependence. Pearson, London

Keohane, R. O. (1986): Realism, Neorealism and the Study of World Politics. Neorealism and its Critics. Columbia University Press, New York 1-26. 
Kis, J. (2000): Alkotmányos demokrácia, Kiadó: Indok Bt. Fundamentum könyvek, ISBN:963-00-42975

Kis, J. (2014): Mi a liberalizmus? Kalligram Kiadó, Pozsony 676-694, ISBN: 9788081018237

Knobloch, U. (1996): Akzent: Deregulierung, Liberalismus: Klassisch, Neo, Ordo, $\begin{array}{llllll}\text { 1996. ZOOM } & \text { K\&M } & \text { Nr. } & \text { 7, } & \text { Februar }\end{array}$ http://www.medienheft.ch/uploads/media/07_ZOOM_KM_07_Ulrike_Knobloch_Li ber alismus klassisch neo ordo.pdf lekérdezve: 2017. február 2.

Kolosi T. - Sági M. (1996): Rendszerváltás és társadalomszerkezet. Társadalmi Riport 1996.TÁRKI, Századvég:149-197.

Kornai, J. (1993): Transzformációs visszaesés. Egy általános jelenség vizsgálata a magyar fejlödés példáján. Közgazdasági Szemle, 40(7-8.) p. 569-599.

Kotz, D. M. (2009): The Financial and Economic Crisis of 2008: A Systemic Crisis of Neoliberal Capitalism. Review of Radical Political Economics 41(3) p. 305-17.

Köves, A. (2003): A KGST-kereskedelemtöl az EU-csatlakozásig. Közgazdasági Szemle, 50(4) p. 635-653.

Land, R. - Busch, U. (2009): Deutschland zwischen 1950 und 2009 Wirtschaftsentwicklung und Teilhabe - Der Teilhabekapitalismus und seine Ende, Entwurf, Okt. 2009.

Langguth, G. (1996): Die Deutschen und ihre nationale Identität - Schwieriger Umgang mit einem vernachlässigten Begriff. Neue Zürcher Zeitung, 12-13. 11.

Lenygel, Gy. - Szántó, Z. (2005): A gazdasági élet szociológiája. Aula Kiadó, Budapest

Locke, J. (1914): Gondolatok a nevelésröl. $\underline{\text { https://uni- }}$ eszterhazy.hu/hefoppalyazat/nevtort/18 john_locke_gondolatok_a nevelsrl.html Lekérdezve: 2020.04.21.

Locke, J. (1986): Értekezés a polgári kormányzatról, Gondolat könyvkiadó, Budapest, ISBN: 963-281-710-9

Ludassy, M. (1991): Az angolszász liberalizmus klasszikusai I-II. Atlantisz könyvkiadó, ISBN: 0729002012711

Macfie, L (1959): Amad Smith's Moral Sentiments as Foundation for his Wealth of Nation, In: Oxford Economic Papers, XI. 3. sz.

Marrese, M. - Vanous J. (1983): Soviet Subsidization of Trade with Eastern Europe. University of California Institute of International Studies 
Marshall, W. (2018): Three Threats to Liberal Democracy. Commentary Prepared for the Biennial Colloquy on the State of Democracy, Centro Studi Americani. Progressive Policy Institute, New Hampshire

Mearsheimer, J. J. (1994): The False Hope of International Institutions. International Security. 19(3), 8.

Mehmet, O. (1999): Westernizing the third world: the Eurocentricity of economic development theories. Routledge, London

Meoqui, J. M. (2014): Reconciling Ricardo's Comparative Advantage with Smith's Productivity Theory, Economic Thought, 3.2. p. 21-37.

Mill, J. S. (1848): Principles of Political Economy with some of their Applications to Social Philosophy. http://www.econlib.org/library/Mill/mlP49.html Lekérdezve: 2019. 02. 13.

Moravcsik, A. (2003): Liberal International Relations Theory: A Scientific Assessment. Elman, C., Fendius Elman, M.: Progress in International Relations Theory: Appraising the Field. MIT Press, Cambridge, p. 159-204.

Morgenthau, H. J. (2005): Politics among nations - The Struggle for Power and peace. McGraw-Hill Education, New York

Mowle, T. S. (2003): Worldviews in Foreign Policy: Realism, Liberalism an External Conflict. Political Psychology, 24(3).

Nagy, F. (2006): Az EU délkeleti bövitésének hatása a magyar mezögazdaságra. http://www.balkancenter.hu/pdf/elemzes/nagyf.pdf Lekérdezve: 2016.04.11.

Nullmeier, F. (2010): Kritik neoliberaler Menschen und Gesellschaftsbilder und Konsequenzen für ein neues Verständnis von ,, sozialer Gerechtigkeit”. Friedrich Ebert Stiftung, Bonn

Nurkse, R. (1953): Problems of capital formation in underdeveloped countries. The Economic Journal, Oxford: Oxford University Press 63(252) p. 897-899.

Office of the United Nations High Commissioner for Human Rights (2007): Good Governance Practices for the Protection of Human Rights. http://www.ohchr.org/Documents/Publications/GoodGovernance.pdf Lekérdezve: 2020.04 .21 .

Pató Szűcs, B. (2008): Nemzetközi közlekedésföldrajz. Nemzeti Szakképzési és Felnőttképzési Intézet https://docplayer.hu/1453657-Munkaanyag-pato-gaborne-drszucs-beata-nemzetkozi-kozlekedesfoldrajz-a-kovetelmenymodul-megnevezesearuterites.html Lekérdezve: 2020.04.21.

Pásztóy, A. (2019): A munka neoliberális világa egy illiberális demokráciában, in Antal: Neoliberális Hegemónia Magyarországon - elemzés és kritika, Noran Libro Kiadó, Budapest, ISBN: 978-615-5900-45-7 
Pearson, A. M. (2016): Realism and Politics Among States in the 21st Century. http://cgsrs.org/publications/5 Lekérdezve: 2017.02.18.

Petőné Csuka, I. - Majoros A. - Somogyi F. (2008): A „homo oeconomicus” fogságában. Polgári Szemle, 4. évf., 2. sz.

Platón összes müvei (1984) I. kötet, Prótagorasz (ford. Faragó László), p. 173-267. ISBN: 963-07-2790-0

R. Polin (1960): La politique morale de Locke, Párizs

Porčnik, T. - Vásquez, I. (2018): Human Freedom Index 2017. Cato Institute, Fraser Institute, Friedrich Naumann Foundation for Freedom, ISBN: 978-1-944424-96-1

Probáld F. - Szabó P. (2005): Európa térszerkezetének modelljei. Dövényi Z., Schweitzer F.: A földrajz dimenziói. MTA Földrajztudományi Kutatóintézet, Budapest, p. 159-170.

Publications Office of the European Union: Framework Agreement Between the United States of America and the European Union on the Participation of the United States of America in European Union Crisis Management Operations. https://op.europa.eu/en/publication-detail/-/publication/aa36c25b-a18a-45cf-bf25$\underline{1 \mathrm{f} 231 \mathrm{bc} 45704 / \text { language-en }}$

Richerson, P. J. (2001): Principles of Human Ecology Chapter 17. http://www.des.ucdavis.edu/faculty/Richerson/BooksOnline/He17-95.pdf

Lekérdezve: 2017.02.18.

Röpke, W. (2000): Emberséges társadalom - Emberséges gazdaság. Aula Kiadó, Budapest - szerkesztette: J. Horváth

Russ, R. (2014): How Adam Smith Can Change Your Life: An Unexpected Guide to Human Nature and Happiness. Penguin Books

Salvucci, P. (1976): Adam Smith politikai filozófiája - filozófiai tanulmányok, Gondolat Kiadó, Budapest, ISBN 963280385 X

Samuelson, P. A. (2009): “A Few Remembrances of Friedrich von Hayek (18991992). ” Journal of Economic Behavior and Organization 69 (1): p. 1-4.

Schumacher, R. (2012): Adam Smith's theory of absolute advantage and the use of doxography in the history of economics, Erasmus Journal for Philosophy and Economics, Volume 5, Issue 2, Autumn 2012, p. 54-80. http://ejpe.org/pdf/5-2-art$\underline{3 . p d f}$

Schumpeter, J. A. (1954): History of Economic Analysis. Oxford Uni-versity Press, New York

Simai, M. (2016): A harmadik évezred nyitánya, Corvina kiadó, Budapest, ISBN: 9789631363852 
Smith, A. (1776, 1977): Wealth of Nations vol. 1., vol. 2., The University of Chicago, ISBN: 0226763749

Smith, A. (1776, 2011): Vizsgálódás a nemzetek jólétének természetéről és okairól, Napvilág kiadó, Budapest, ISBN: 9789633380505

Smith, S. - Booth, K. - Zalewski, M. (1996): International Theory: Positivism an Beyond. Cambridge University Press, Cambridge

Stanley, C. E. (1973): A note on Adam Smith's version of the vent for surplus model. History of Political Economy. 5(2), p. 438-448.

Stehr, N. (2017): A szabadság a tudás leánya. Gondolat Kiadó kör, Budapest

Szentes, T. (2006): Az állam szerepe a felgyorsult globalizáció korában Közgazdaság, 1 (1). p. 15-45.

Takács, V. - Máté, Á. - Nagy, S. Gy. (2014.): Adószerkezeti változások az Európai Unióban, Köz-gazdaság, különszám az adópolitikáról, 2014/4. p. 127-144.

Tóth, Cs. (2016): A sci-fi politológiája. Athenaeum kiadó, Budapest ISBN: 9789632935287

Treaty of Rome (1957): $\quad$ http://eur-lex.europa.eu/legalcontent/EN/TXT/?uri=LEGISSUM:xy0023

United Nations: The System of the United Nations: https://www.un.org/en/pdfs/un_system_chart.pdf

United Nations: Charter of the United Nations, Chapter I.: https://www.un.org/en/sections/un-charter/chapter-i/index.html

Vezzali, L. - Stathi, S. - Giovannini, D. - Capozza, D. Trifiletti, E. (2014): The greatest magic of Harry Potter: Reducing prejudice, Journal of Applied Psychology, Vol. $42(2)$

Young, B. (2014): Ordoliberalismus - Neoliberalismus - Lassez-faire Liberalismus: Theorien der Internationalen Politischen Ökonomie, p. 33-43.

Zala, T. (2006): A New Deal szociálpolitikai vetületben, Történelmi szemle, 86/2, p. 380-389. 